\title{
LARGE SCAPHITID AMMONITES (HOPLOSCAPHITES) FROM THE UPPER CRETACEOUS (UPPER CAMPANIAN-LOWER MAASTRICHTIAN) OF NORTH AMERICA: \\ ENDLESS VARIATION ON A SINGLE THEME
}

NEIL H. LANDMAN, W. JAMES KENNEDY, JOYCE GRIER, NEAL L. LARSON, JAMES W. GRIER, THOMAS LINN, LYDIA TACKETT, AND BRIAN R. JICHA

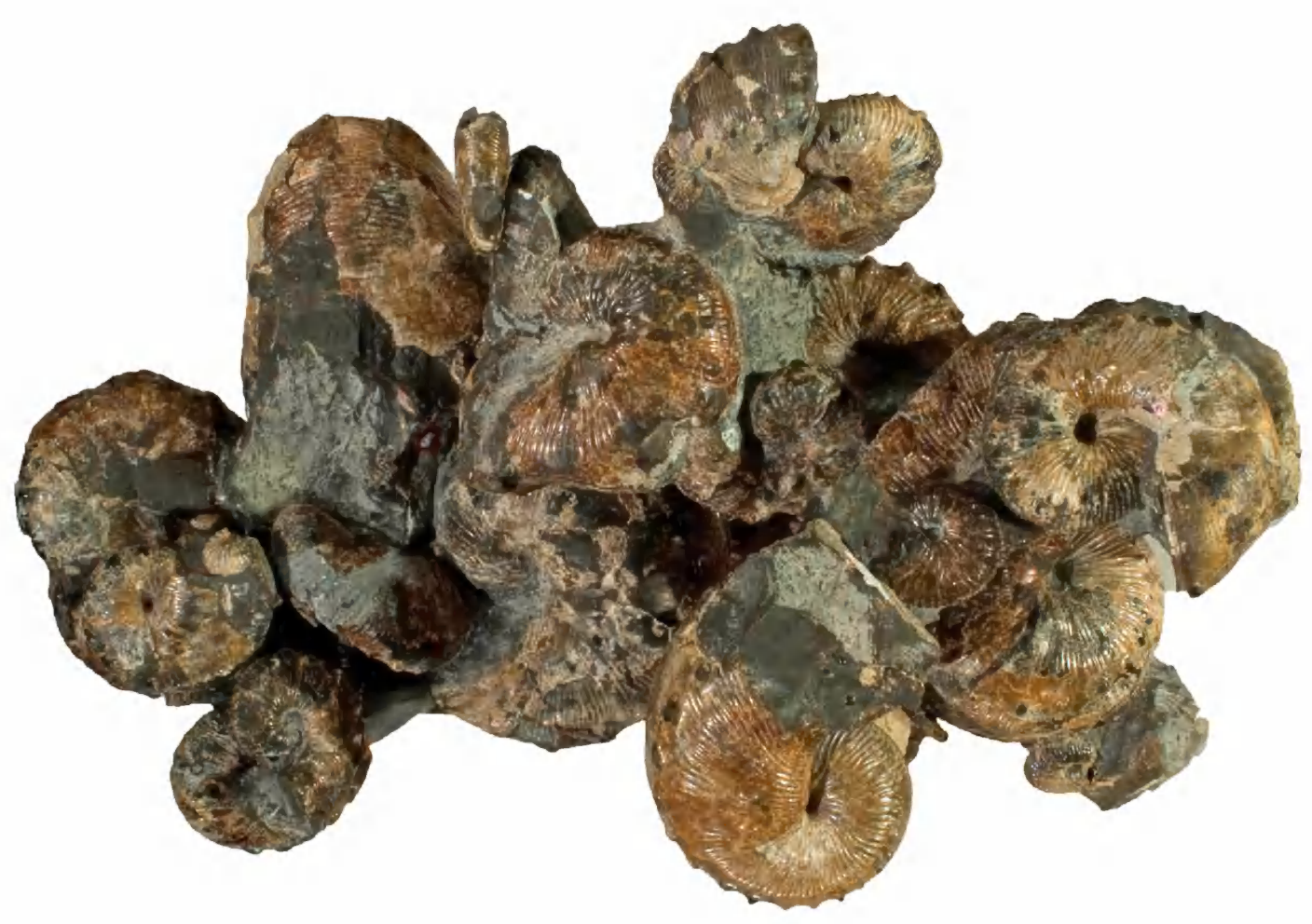

BULLETIN OF THE AMERICAN MUSEUM OF NATURAL HISTORY 


\section{LARGE SCAPHITID AMMONITES (HOPLOSCAPHITES) FROM THE UPPER CRETACEOUS (UPPER CAMPANIAN-LOWER MAASTRICHTIAN) OF NORTH AMERICA: ENDLESS VARIATION ON A SINGLE THEME}

NEIL H. LANDMAN

Department of Invertebrate Paleontology, American Museum of Natural History, New York

W. JAMES KENNEDY

Oxford University Museum of Natural History, Oxford

JOYCE GRIER

NEAL L. LARSON

Larson Paleontology Unlimited, Keystone, South Dakota

JAMES W. GRIER

Department of Biological Sciences, North Dakota State University, Fargo

THOMAS LINN

Early Earth Enterprises, Glendive, Montana

LYDIA TACKETT

Department of Geosciences, North Dakota State University, Fargo

BRIAN R. JICHA

Department of Geoscience, University of Wisconsin, Madison

BULLETIN OF THE AMERICAN MUSEUM OF NATURAL HISTORY

Number 441, 131 pp., 78 figures, 6 tables

Issued September 14, 2020 


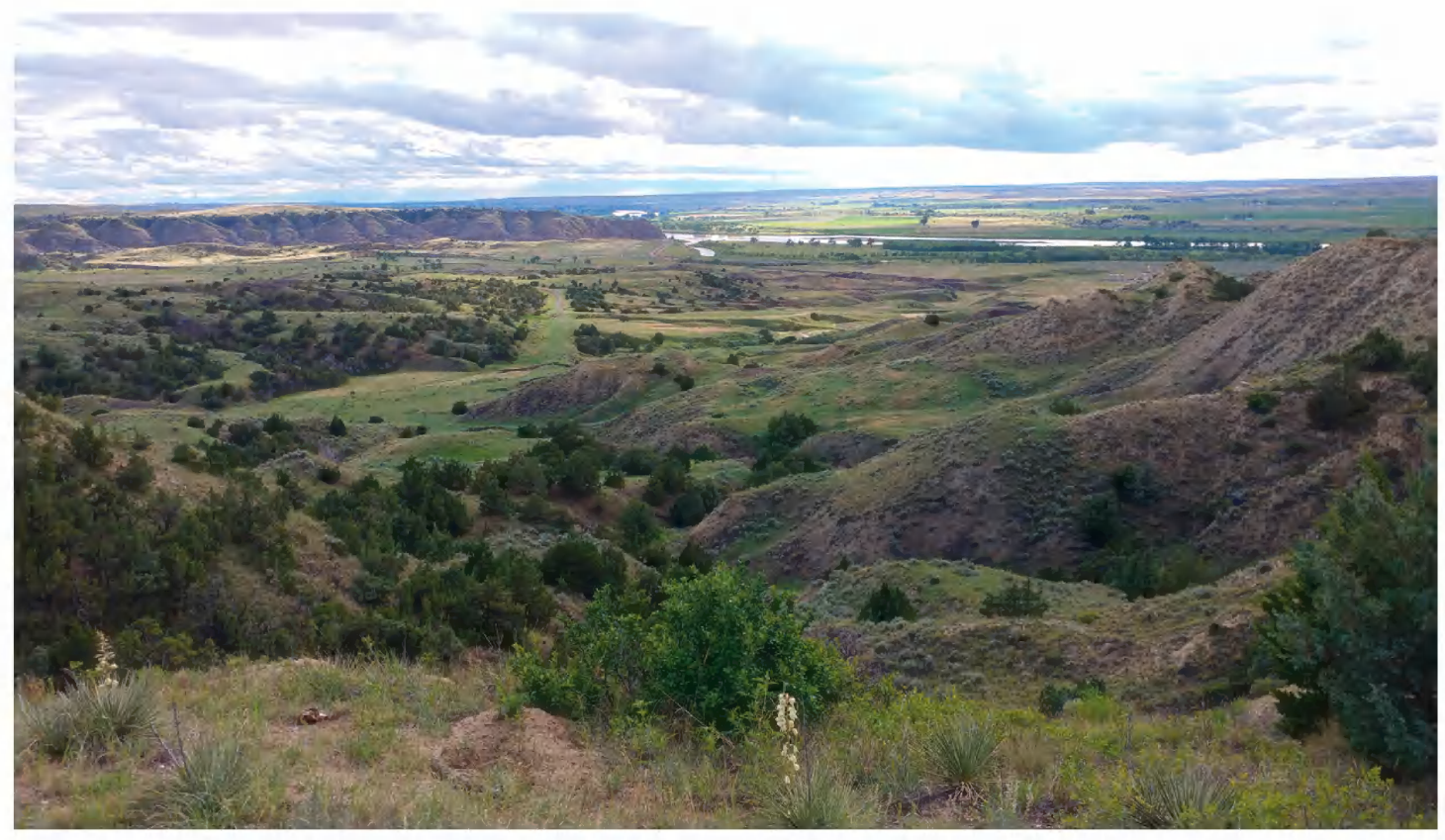

FRONTISPIECE. Breaks along the Yellowstone River (background) exposing the Upper Cretaceous Pierre Shale on the Cedar Creek Anticline, Dawson County, Montana. This is one of the classic sites first explored by Ferdinand V. Hayden during the 1850s, and the source of some of the largest species of Hoploscaphites in North America. Photo by T. Linn. 


\section{CONTENTS}

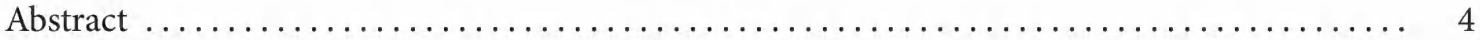

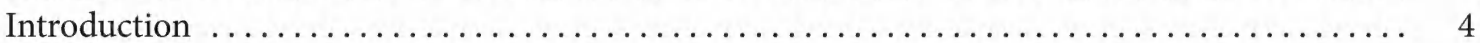

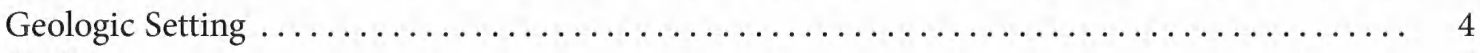

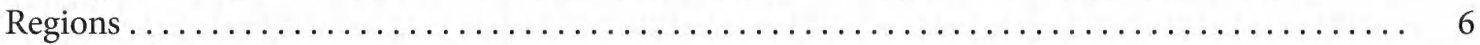

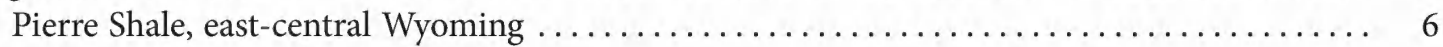

Bearpaw Shale, northeast Montana.............................. 7

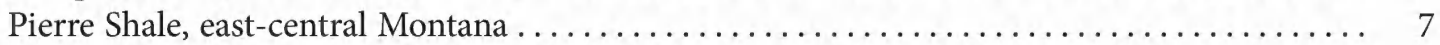

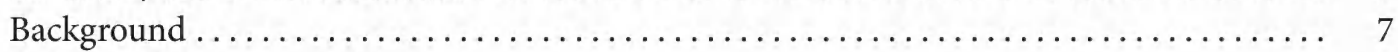

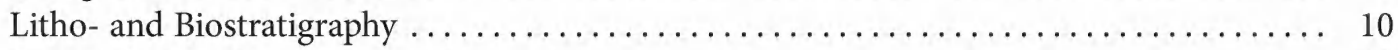

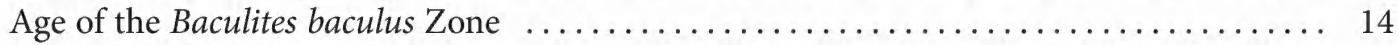

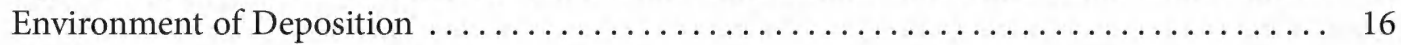

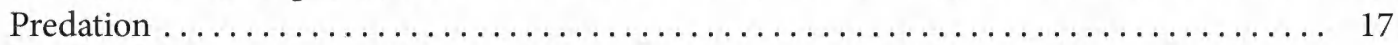

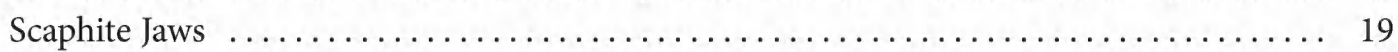

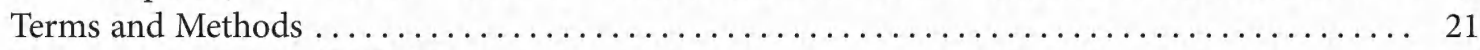

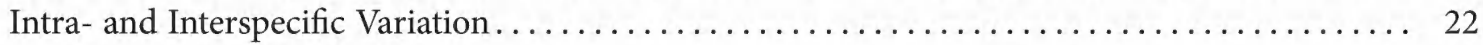

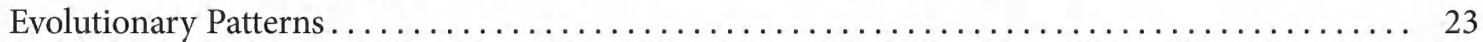

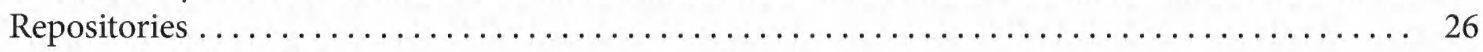

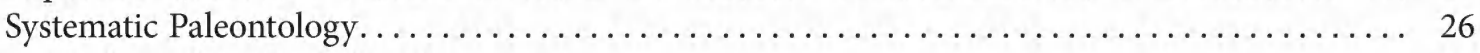

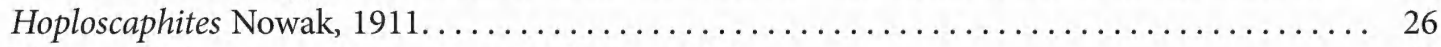

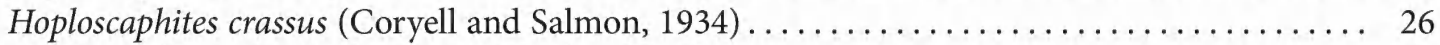

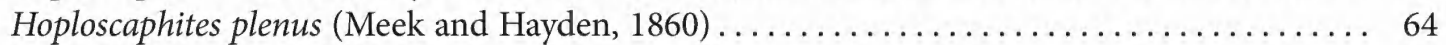

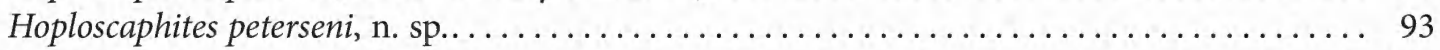

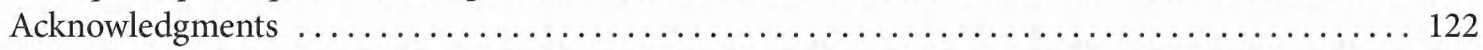

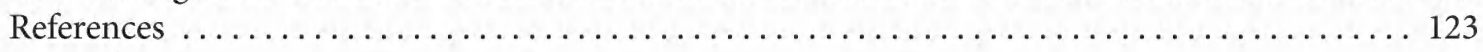

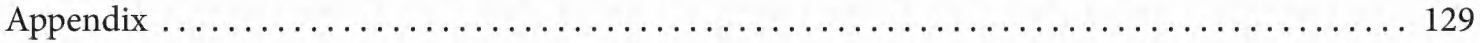




\begin{abstract}
'
We describe three species of large scaphitid ammonites (Ammonoidea: Ancyloceratina) from the Upper Cretaceous (upper Campanian-lower Maastrichtian) of the Western Interior of North America. Each species occurs as two dimorphs, referred to as macroconch and microconch. All three species share a similar pattern of ornamentation consisting of long, thin, nonbifurcating ribs on the adoral part of the phragmocone, suggesting that they constitute a single monophyletic clade. Macroconchs of Hoploscaphites crassus (Coryell and Salmon, 1934) are characterized by a globose whorl section, with closely spaced ventrolateral tubercles on the body chamber, usually persisting to the aperture. Macroconchs of Hoploscaphites plenus (Meek and Hayden, 1860) differ from those of $H$. crassus in having a more subquadrate whorl section with flatter flanks, and fewer, larger, and more widely spaced ventrolateral tubercles. Macroconchs of Hoploscaphites peterseni, n. sp., closely resem-

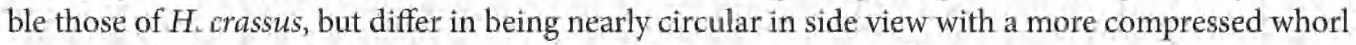
section. All three species lived at approximately the same time in the same general area and depositional environment. They are abundant in the Baculites baculus Zone but also occasionally occur in the B, eliasi Zone and possibly lower part of the B, grandis Zone. They are present in the Pierre Shale of east-central Montana and east-central Wyoming, the Lewis Shale of south-central Wyoming, and the Bearpaw Shale of northeast Montana. It is possible that these three species represent subspecies within a single species or a "flock" of very closely related species, similar to the "species flocks" observed in modern cichlid fishes.
\end{abstract}

\section{INTRODUCTION}

Heteromorph ammonites of the genus Hoploscaphites Nowak, 1911, are important biostratigraphic markers in Upper Cretaceous (middle Campanian to Maastrichtian) rocks in the Western Interior of North America. They first appear in the Baculites asperiformis Zone and extend to the $H$, nebrascensis Zone. All of the species are endemic to North America, although they have occasionally been reported from Western Europe, but only as fragments (Machalski et al., 2007). In this paper, we describe three species of Hoploscaphites, one of them new, from the upper Campanian to lower Maastrichtian of North America.

In general, the species of Hoploscaphites from the Western Interior of North America are abundant and well preserved. Indeed, some of the species in our study are represented by hundreds of specimens derived from single horizons. Their excellent preservation is due to rapid burial after death and fossilization in early diagenetic carbonate concretions. As a result, these ammonites are well suited for taxonomic study. They permit a detailed examination of morphology, including jaws and muscle scars. They also lend themselves to an investigation of the range of variation within and between species and how these considerations affect the definition of a species. This is an active area of investigation in ammonite systematics (for a review of this subject, see deBaets et al., 2015).

\section{Geologic Setting}

The Western Interior Seaway (WIS) was a broad epicontinental seaway that extended from western Canada to the proto-Gulf of Mexico during the Late Cretaceous (Cobban and Reeside, 1952; Williams and Stelck, 1975). The western margin of the WIS was bordered by a north-south trending unstable cordillera; the eastern margin was formed by the low-lying platform of the conterminous United States and Canada (Shurr et al., 1994). The position of the western margin of the WIS during the Late Cretaceous has been inferred based on the meticulous mapping studies of Gill and Cobban (1966) and Cobban et al. (1994). Figure $1 \mathrm{~A}$ illustrates the position of the shoreline during the late Campanian and early Maastrich- 


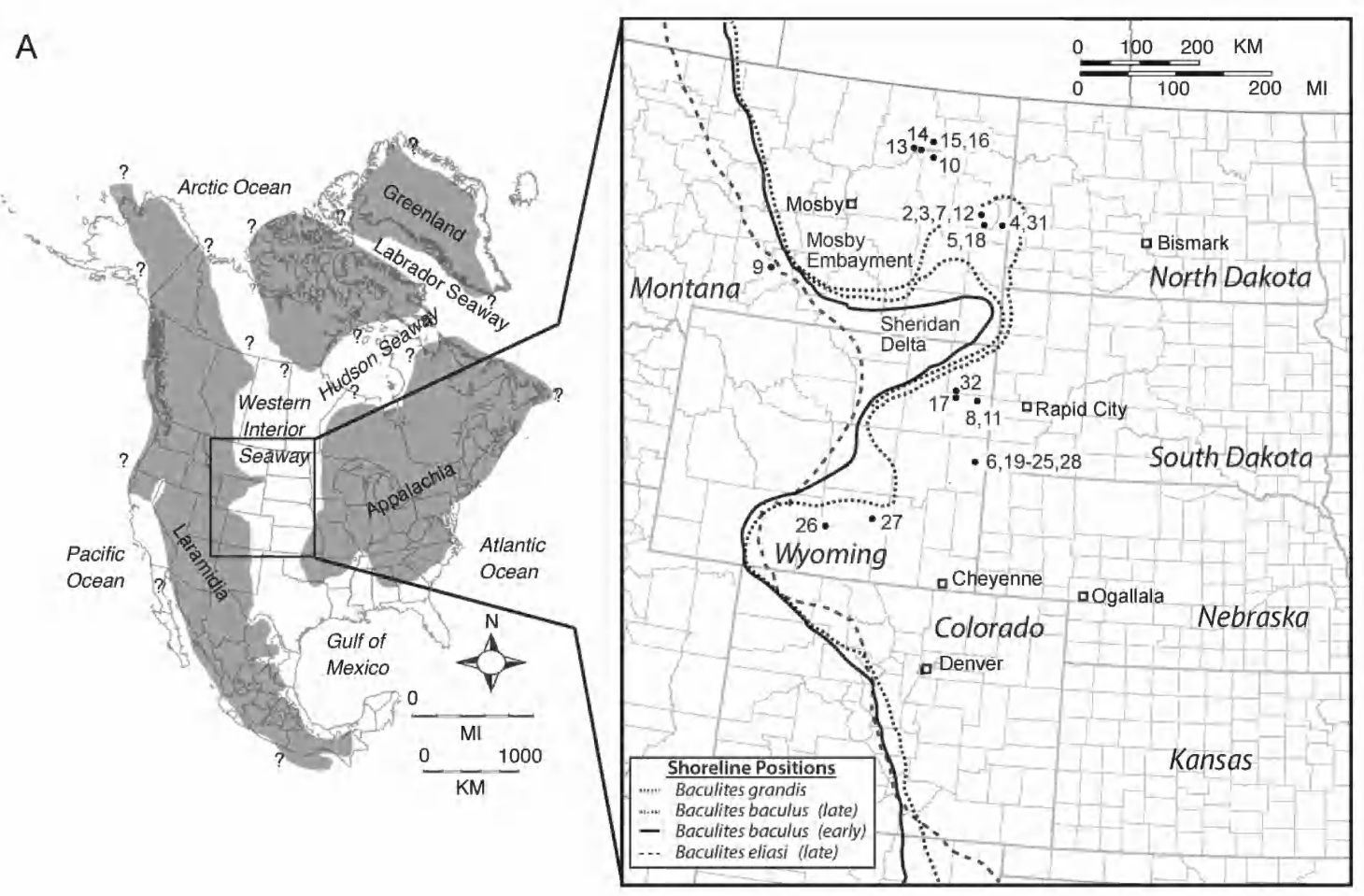

B

\begin{tabular}{|c|c|c|c|c|}
\hline \multirow{2}{*}{\multicolumn{2}{|c|}{ Stage }} & \multicolumn{3}{|c|}{ Western Interior of North America } \\
\hline & & \multirow{2}{*}{$\begin{array}{l}\text { Ammonite Zones } \\
\text { Baculites clinolobatus }\end{array}$} & \multirow{2}{*}{$\begin{array}{l}\text { Inoceramid Zones } \\
\text { "Inoceramus" balchii }\end{array}$} & \multirow{2}{*}{$\begin{array}{l}\text { Age (Ma) } \\
70.08 \pm 0.37^{1}\end{array}$} \\
\hline \multirow{4}{*}{ 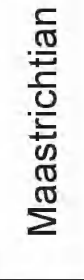 } & \multirow{4}{*}{ 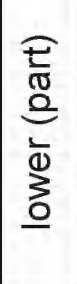 } & & & \\
\hline & & Baculites grandis & Trochoceramus radiosus & $70.66 \pm 0.66^{1}$ \\
\hline & & \multirow{2}{*}{ Baculites baculus } & "Inoceramus" incurvus & \multirow{2}{*}{$71.96 \pm 0.08$} \\
\hline & & & Endocostea typica & \\
\hline 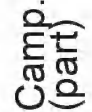 & 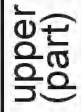 & Baculites eliasi & "Inoceramus" redbirdensis & $72.50 \pm 0.31^{1}$ \\
\hline
\end{tabular}

FIGURE 1. A. Overview of the Late Cretaceous Western Interior Seaway (left) and close-ups of the shoreline positions (right) during the deposition of the upper Campanian-lower Maastrichtian Baculites eliasi-B. grandis zones (modified from Landman et al., 2016). The numbered dots indicate localities cited in the text, as listed in the appendix. B. Biostratigraphic chart of part of the Upper Cretaceous (upper upper Campanian and lower lower Maastrichtian) of the Western Interior of North America showing ammonite and inoceramid zones (modified from Cobban et al., 2006). The age of each zone, as determined by ${ }^{40} \mathrm{Ar} /{ }^{39} \mathrm{Ar}$ dating of bentonites, is shown on the right. Source: ${ }^{1}=$ Lynds and Slattery $(2017) ;{ }^{2}=$ this report. 
tian, the focus of our study. At the time, the shoreline formed a broad embayment in Montana (called the Mosby Embayment) separated from the rest of the WIS by a peninsula in the southeastern corner of the state (called the Sheridan Delta; Reiskind, 1975). The shoreline then cut to the southwest as a series of embayments as far as south-central Wyoming, and then cut southeastward across the middle of Colorado.

We utilize the biostratigraphy of the Upper Cretaceous Western Interior established by Cobban et al. (2006) based on ammonites and inoceramids. Accordingly, the upper part of the upper Campanian comprises the Baculites jenseni and B, eliasi zones (fig. 1B). The lower part of the lower Maastrichtian comprises the B. baculus and $B$. grandis zones. The lower part of the $B$. baculus Zone coincides with the Endocostea typica inoceramid Zone and the upper part of the $B$. baculus Zone coincides with the "Inoceramus" incurvus inoceramid Zone; the B. grandis Zone coincides with the Trochoceramus radiosus inoceramid Zone (fig. 1B). The CampanianMaastrichtian boundary is placed at the base of the $B$. baculus Zone coincident with the base of the E. typica Zone (Walaszczyk et al., 2001; Cobban et al, 2006). The ages of these zones are based on radiometric dating of bentonites (fig. 1B) and are published in Cobban et al. (2006) and updated in Lynds and Slattery (2017) and this report (see below).

The localities referred to in this study are located in Montana and Wyoming within 200 $\mathrm{km}$ of the western shoreline of the WIS, depending on the time (fig. 1A). With the retreat of the WIS during the late Campanian and early Maastrichtian, the shoreline prograded eastward in association with the development of the Sheridan Delta, reflecting the shedding of sediments from regional uplifts in the area of the Big Horn and Granite Mountains (Krystinik and DeJarnett, 1995). Most studies suggest that the WIS at the time was less than $100 \mathrm{~m}$ deep (Gill and Cobban, 1966; Kauffman and Caldwell, 1993). However, the depth at each locality depends on the particular time slice under consideration. For example, the depth of the WIS on the Cedar Creek Anticline in east-central Montana during the deposition of the upper part of the Baculites baculus Zone was probably less than $50 \mathrm{~m}$ (Landman et al., 2019).

We describe three species of Hoploscaphites: H. crassus (Coryell and Salmon, 1934), H. plenus (Meek and Hayden, 1860), and H. peterseni, n. sp. These species are abundant in the B. baculus Zone but also occasionally occur in the B. eliasi Zone and possibly lower part of the $B$. grandis Zone. They are present in the Pierre Shale of east-central Montana and east-central Wyoming, the Lewis Shale of south-central Wyoming, and the Bearpaw Shale of northeast Montana. Hoploscaphites crassus and $H$. plenus also occur in the B. eliasi and $B$. baculus zones of the Bearpaw Shale of Saskatchewan and Alberta (Riccardi, 1983). Three other species of Hoploscaphites were previously described from the same general area: H. macer Landman et al., 2019, and H. criptonodosus Riccardi (1983) from the upper part of the $B$. baculus and lower part of the B. grandis zones, and $H$. sargklofak Landman et al., 2015a, from the $B$. grandis Zone. In the following discussion, we describe three stratigraphic sections (the Bearpaw Shale, Garfield County, Montana; the Pierre Shale, Nobrara County, Wyoming; and the Pierre Shale, east-central Montana) in detail because they form an integral part of our study.

\section{REGIONS}

\section{Pierre Shale, East-Central Wyoming}

Many of the specimens in our study are derived from the Pierre Shale in east-central Wyoming. The upper Campanian and lower Maastrichtian section at Red Bird, Niobrara County, Wyoming, is nearly complete, and as such, was designated as the informal reference section for the Pierre Shale by Gill and Cobban (1966). It has inspired much research (e.g., Hicks et al., 1999; Slattery et al., 2018; Landman, in press), and we briefly review some stratigraphic details pertinent to the present study (fig. 2). 
The Baculites eliasi Zone occupies the upper part of the lower unnamed shale member, the Kara Bentonitic Member, and the lower part of the upper unnamed shale member. The lower unnamed shale member is $720 \mathrm{ft}(219 \mathrm{~m})$ thick and consists of alternating bands of dark, medium, and light-gray weathering shale. It contains abundant fossiliferous limestone concretions that yield specimens of Hoploscaphites plenus (USGS loc. D1636). The Kara Bentonitic Member is $36 \mathrm{ft}(11 \mathrm{~m})$ thick at Red Bird and consists of gray weathering shale and bentonitic shale with a $6 \mathrm{ft}(1.8 \mathrm{~m})$ thick bentonite bed at its base. It is capped with a ridge-forming concretionary limestone bed that yields specimens of H. crassus (USGS loc. D1967). The upper unnamed shale member is $680 \mathrm{ft}(207 \mathrm{~m})$ thick at Red Bird and consists of sandy and silty shale representing dark and light-gray bands. According to Gill and Cobban (1966), the base of the $B$. baculus Zone is $61 \mathrm{ft}(19 \mathrm{~m})$ above the top of the Kara Bentonitic Member. We have identified specimens of $H$. crassus and $H$. peterseni from limestone concretions in the lower part of this zone (USGS locs. D1975, D1976, and D1981). The known occurrence of each species of Hoploscaphites in the section is indicated by a solid vertical line in figure 2 , although it is likely that all three species range throughout the stratigraphic interval from USGS loc. D1636 to D1981 (dashed vertical lines in fig. 2).

\section{Bearpaw Shale, Northeast Montana}

The Bearpaw Shale in northeast Montana is the source of several specimens in our study (fig. 3). The formation was named and described by Stanton and Hatcher (1905) for exposures north, east, and south of the Bearpaw Mountains in central Montana. It was further described by Jensen and Varnes (1964) in Garfield, McCone, and Valley counties, Montana. It is approximately $1440 \mathrm{ft}(439 \mathrm{~m})$ thick in this area and lies between the Judith River Formation below and the Fox Hills Formation above. It consists of dark gray clayey and silty shale, with intermittent bentonites. Most fossils occur in small to medium size concretions, although a few occur in larger septarian concretions. In the stratigraphic section prepared by W.A. Cobban et al. (personal commun., 1948) reproduced here (fig. 3), the Baculites compressus, B. jenseni, B. eliasi, B. baculus, and $B$. grandis zones are present. We have identified specimens of Hoploscaphites peterseni from limestone concretions at USGS loc. 22142.

\section{Pierre Shale, East-Central Montana}

BACKGRound: Most of the specimens in our study are from the Cedar Creek Anticline, which represents a major structural feature demarcating the southwestern flank of the Williston Basin, Montana (Clement, 1986; Peterson and Maccary, 1987). The anticline extends southeast approximately $235 \mathrm{~km}$ from northwest of Glendive, Montana, to just west of Buffalo in northwestern South Dakota. According to Clement (1986: 236), "the present Cedar Creek axis was breached during epeirogenic uplift of middle Tertiary time that removed at least $460 \mathrm{~m}$ of Paleocene and Upper Cretaceous strata." The soft Pierre Shale is exposed along the axis of the anticline and the more resistant Fox Hills, Hell Creek, and Fort Union formations are exposed on the flanks (Linn, 2010: Grier et al., 2019).

This is one of the classic Cretaceous localities first explored by Ferdinand V. Hayden in the 1850 's (frontispiece). Hayden, along with Fielding B. Meek, both young assistants of New York State Geologist James Hall, began their joint field trips in the area of the present-day Black Hills, South Dakota, in 1853. Later, under partial support from the Smithsonian Institution, Hayden spent the summer of 1854 in the region around Fort Union (located in Williams and McKenzie counties, North Dakota, and Roosevelt and Richland counties, Montana), collecting fossils on the Cedar Creek Anticline along the Yellowstone River and at the mouths of the Powder, Tongue, and Bighorn rivers. After returning home to Rochester, New York, he 


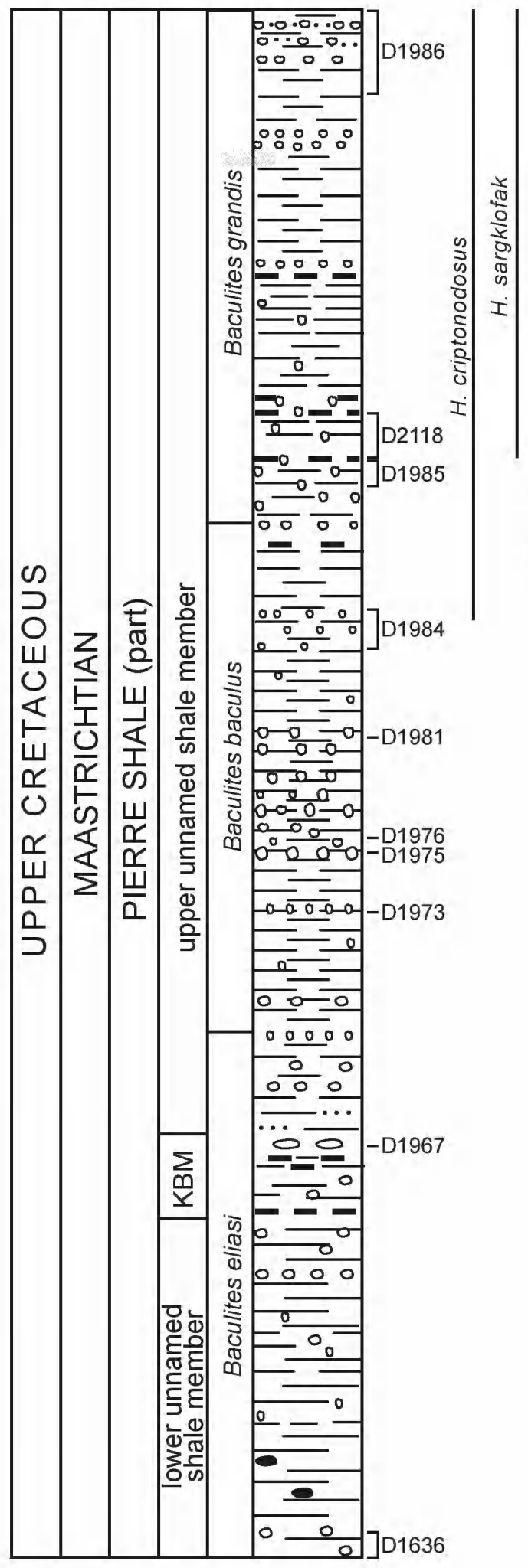

FIGURE 2. Stratigraphic section of the Pierre Shale at Red Bird, Niobrara County, Wyoming (modified from Gill and Cobban, 1966), showing the ranges of six species of Hoploscaphites (solid vertical lines = known occurrences; dashed vertical lines = likely occurrences). The D numbers refer to USGS Mesozoic localities cited in the text $\mathrm{KBM}=$ Kara Bentonitic Member.

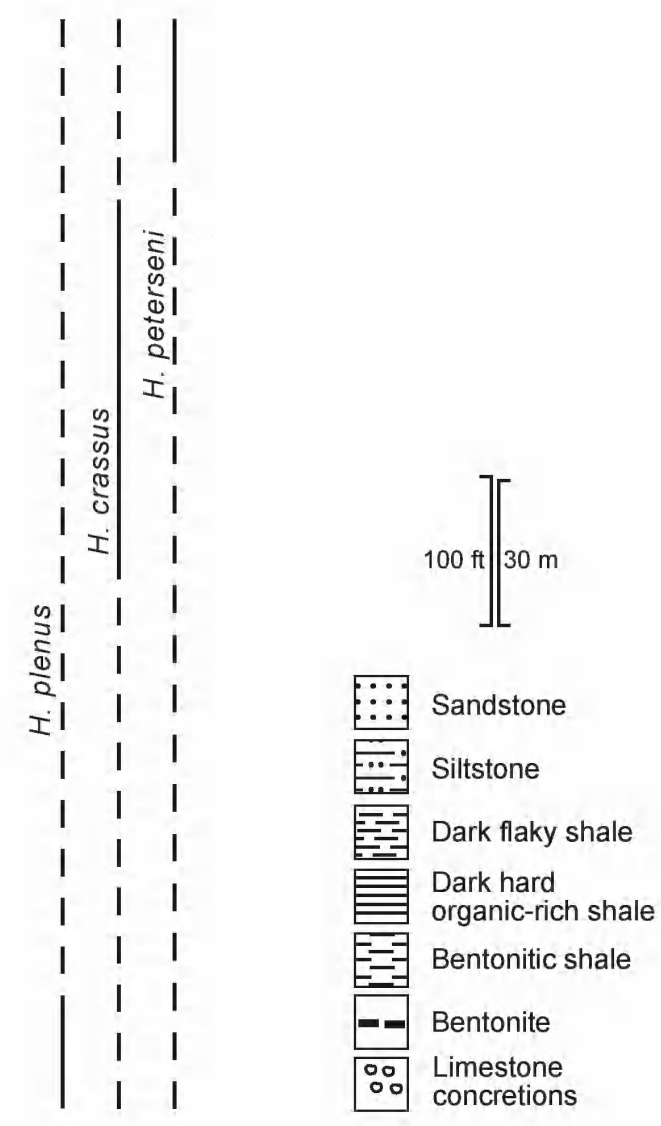




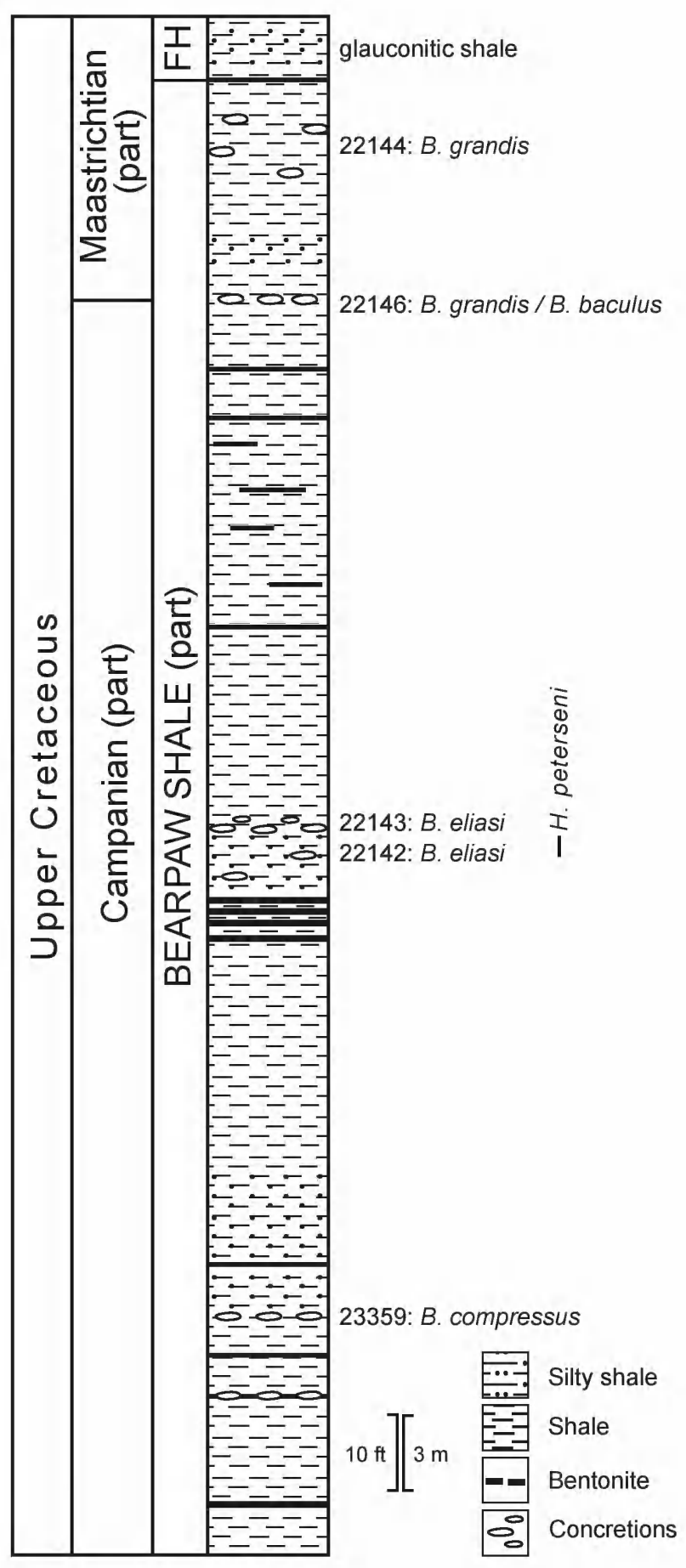

FIGURE 3. Stratigraphic section of the Bearpaw Shale measured by W.A. Cobban, F.S. Jensen, F.T. Fischer, and H.H. Camecho, 1948, about $1 \mathrm{mi}(1.6 \mathrm{~km})$ east of Ft. Peck spillway, E1/2 sec. 5 and W1/2 sec. 4, T. 26 N., R. 42 E., Valley County, Montana. The stratigraphic range of Hoploscaphites peterseni, n. sp., is shown by a short vertical line. The numbers refer to USGS localities cited in the text. FH = Fox Hills Formation. 
later spent the summer of 1855 around Fort Benton, Montana, collecting fossils along the Missouri River and its tributaries under the aegis of Alexander Culbertson, the agent in charge of all the forts in the Upper Missouri and Yellowstone rivers.

In January, 1856, Hayden stopped in St. Louis, bringing with him his fossil haul from the previous two years. According to Foster (1994: 66), the collection presented "an extraordinary harvest: six tons of specimens accumulated over two years, including more than a thousand pounds of fossils he wanted to work up with Meek, which he expected would occupy them for five years." Meek saw some of the specimens in early February 1856, pronouncing them "grand-magnificent. All of them as perfect as recent shells. There are not less than 50 species most of which are new" (quoted in Foster, 1994: 67).

Meek and Hayden published checklists and descriptions of these fossils in installments starting in 1856, culminating in Meek's massive monograph of 1876, containing the full description of Hoploscaphites plenus. Although Hayden made additional field trips out west in the intervening years, Meek's monograph was based on material collected in 1854-1855. According to Hayden (in Meek, 1876: iii, iv), "The accumulation of the materials which compose this volume was commenced in the spring of 1854, and the greater number of the new species of fossils were discovered by the writer of this letter during that and the succeeding year."

By the late 1800 's, the Cedar Creek Anticline was a popular destination for fossil collecting. Interestingly, many of the specimens in U.S. museums that date from that era cite the locality as Mingusville, Montana. This name does not appear on any map today. According to Landman et al. (2018), the name originated as a contraction of two names: Gus Grisy and his wife,
Minnie, who ran a cattle ranch at the time (hence the name Min-gus). In 1893, the name was officially changed to Wibaux in recognition of another rancher, Pierre Wibaux. A statue of Wibaux stands a short distance west of the town, which lies on the northern edge of the anticline in Wibaux County, Montana.

LITHO- AND BIOSTRATIGRAPHY: The lithoand biostratigraphy of the Upper Cretaceous part of the Cedar Creek Anticline has been recently reviewed by Landman et al. (2018a, 2019) and Grier et al, (2019). The Pierre Shale consists of light to dark gray, fissile, silty or sandy shale 60-65 $\mathrm{m}$ thick, interbedded with bentonites and bentonitic shale. It contains iron manganese ( $\mathrm{Fe}-\mathrm{Mn}$ ), limestone, and sandstone concretions, some of which are abundantly fossiliferous. The Pierre Shale becomes progressively siltier near the top and is overlain by the Fox Hills Formation. The Pierre Shale is late Campanian to early Maastrichtian in age and contains the upper part of the Baculites eliasi, B. baculus, and lower part of the $B$. grandis zones (fig. 4).

The Baculites eliasi Zone is approximately $38 \mathrm{~m}$ thick, representing slightly more than one-half the thickness of the Pierre Shale in the area (fig. 5E, F). The age of this zone is $72.50 \pm 0.31 \mathrm{Ma}$ (fig. 1B). Specimens of B, eliasi Cobban, 1958, are present in iron manganese (Fe-Mn) and limestone concretions, and occasionally loose in the sediment as body chamber casts. The abundance of $B$. eliasi diminishes toward the top of the zone to the point where specimens are very rare. Gill and Cobban (1966) and Slattery et al. (2018) observed a similar reduction in the number of specimens of $B$. eliasi toward the top of the zone in east-central Wyoming. In fact, the rarity or near-absence of $B$. eliasi, and B. baculus Meek and Hayden, 1861, from the overlying zone, has led to uncertainty in

FIGURE 4. Stratigraphic section of the Pierre Shale and Fox Hills Formation near Glendive, Dawson County, Montana, on the northwestern end of the Cedar Creek Anticline, slightly modified from the latest iteration (Landman et al., 2019) to include the presence of cold methane seep deposits. The ranges of six species of Hoploscaphites are illustrated (solid vertical lines = known occurrences; dashed vertical lines = likely occurrences). The relative abundances of $H$. crassus (Coryell and Salmon, 1934), H. plenus (Meek and Hayden, 1860 ), and $H$. peterseni are represented as spindle diagrams based on a subsample of specimens that were collected with tight stratigraphic control. 


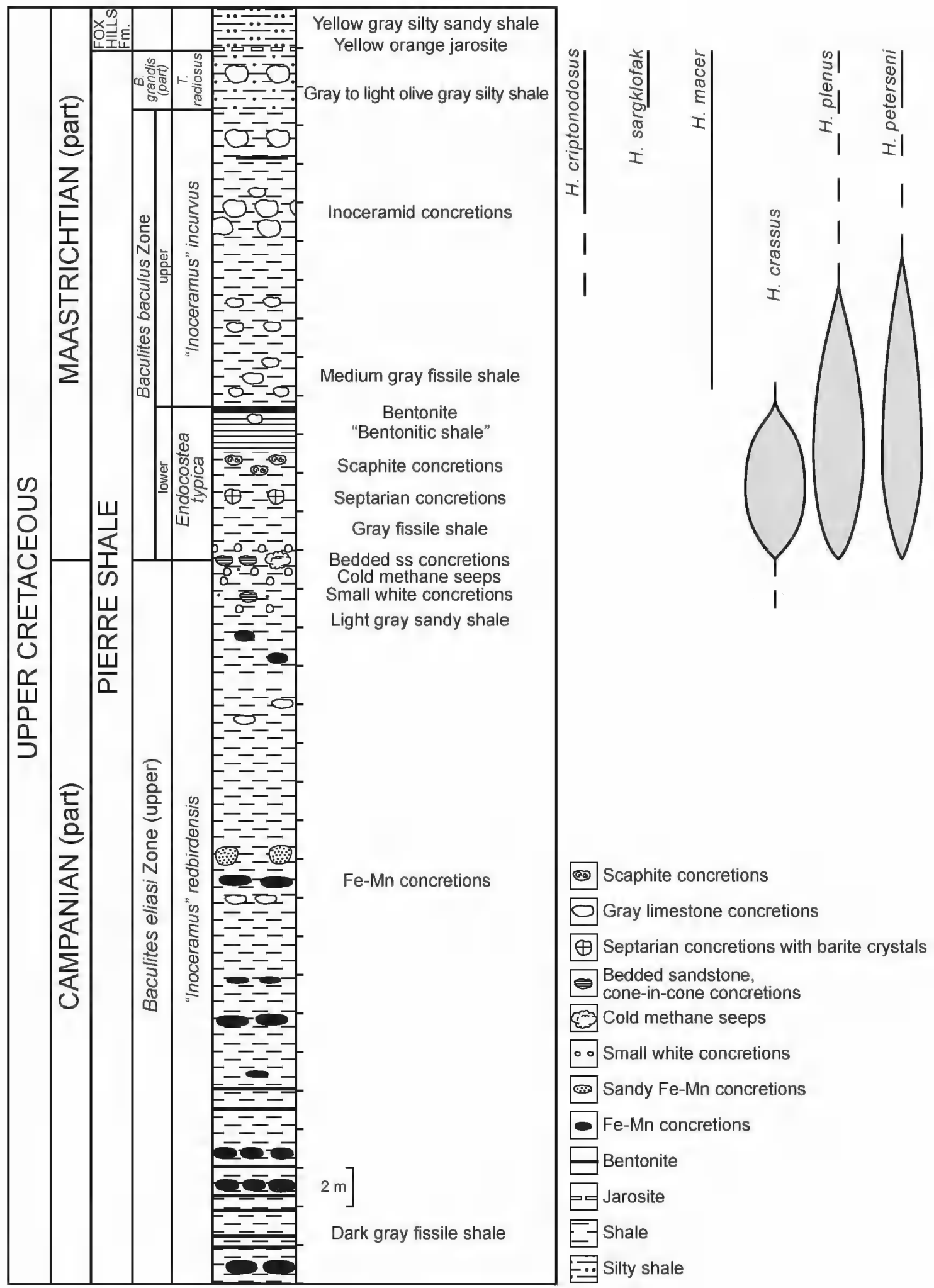




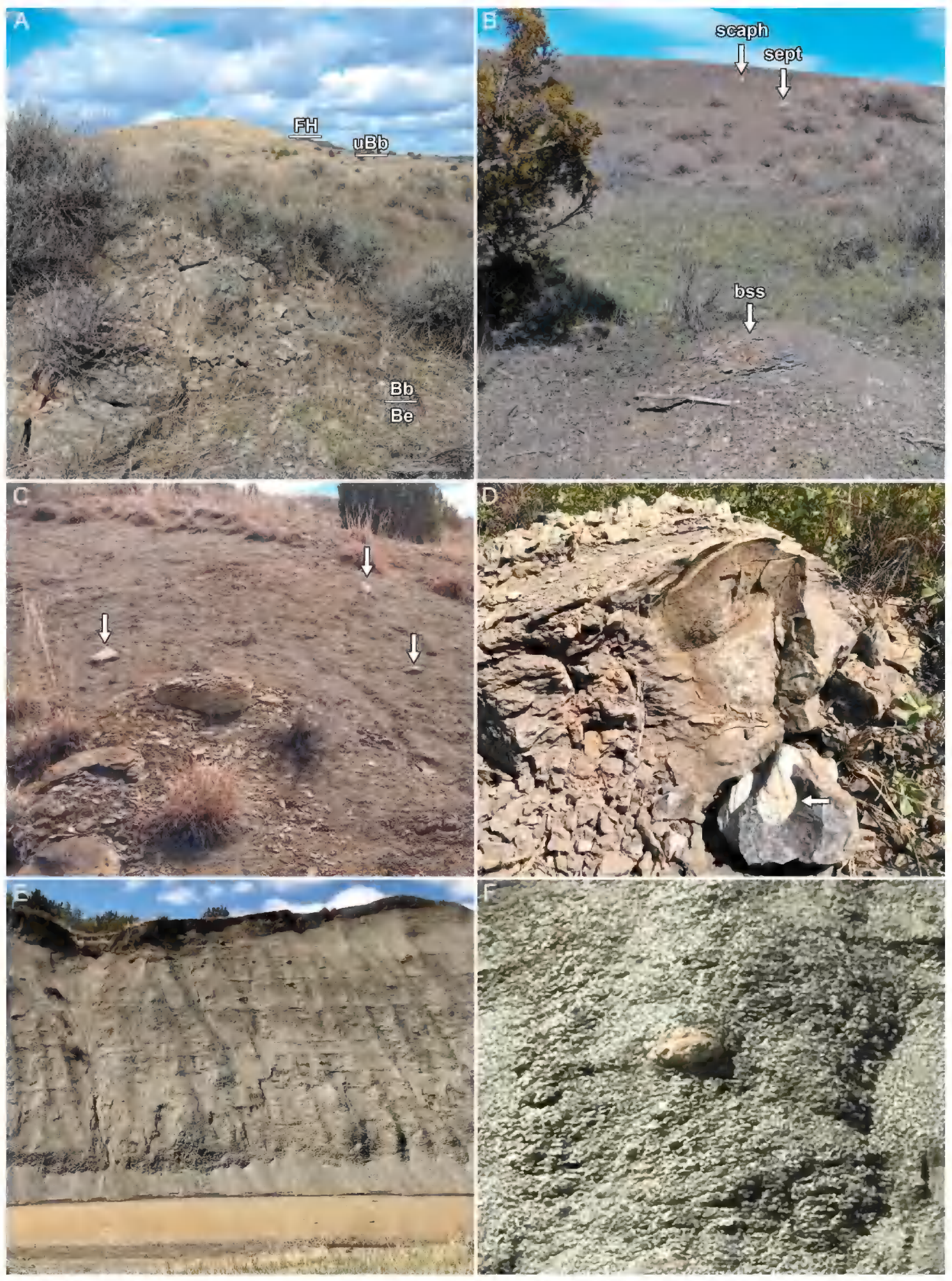


the precise placement of the Campanian/Maastrichtian boundary, a problem in the Western Interior in general (Gill and Cobban, 1966; Riccardi, 1983). The Campanian/Maastrichtian boundary appears to be linked to an interval of global cooling, based on studies of sections from the U.S. Gulf Coastal Plain and elsewhere (see Linnert et al., 2018, and references therein).

In the northwestern part of the Cedar Creek Anticline, Bishop $(1967,1973)$ documented a discontinuous layer of brownish-tan to yellowish weathering, horizontally laminated sandstone concretions that he referred to as the "bedded concretions." They are associated with small (15$20 \mathrm{~cm}$ in maximum length), whitish-gray weathering, round to flat carbonate concretions (figs. $4,5 \mathrm{~B}-\mathrm{D})$. Both the bedded concretions and the small whitish-gray concretions occur in a lightgray sandy shale. A few specimens of Baculites eliasi are present less than $1 \mathrm{~m}$ below the layer of bedded sandstone concretions. Fossils are rare in the bedded concretions themselves, but a few specimens of $B$. baculus, Endocostea typica (Whitfield, 1877), Nostoceras sp., and Hoploscaphites sp., are present (fig. 4D). The co-occurrence of B. baculus and E. typica marks the base of the B. baculus and E. typica zones, respectively, indicating the base of the Maastrichtian.

We studied the sedimentology of the bedded sandstone concretions using petrologic thin sections of a single concretion collected in situ. The concretion shows stratigraphic variation in grain size, mineral composition, and degree of lithification from bottom to top. The lower part of the concretion is very fissile and soft, and does not display any primary sedimentary structures in hand samples or thin section. Ferruginous grains are visible and stand out from the surrounding muddy matrix (fig. $6 \mathrm{E}, \mathrm{F}$ ). The middle part of the concretion exhibits the highest degree of lithification and breaks into parallel laminations that may reflect remnant bedding planes. This part of the concretion consists of well-sorted, fine sand-sized quartz grains associated with iron-manganese and ferruginous grains, which are larger than those in the lower part of the concretion (fig. $6 \mathrm{~B}, \mathrm{C}$ ). The quartz grains show sutured boundaries (edges of the grains are pressed together with no cement between). Fecal pellets and longer filaments of unknown origin are rare (fig. 6B, C). The upper part of the concretion breaks into thin ( $\sim \mathrm{cm}$ thick), friable laminations. Ferruginous grains are present and similar in size and composition to those in the middle part of the concretion, but much less abundant (fig. 6A). This variation in grain size, amount of quartz, and degree of lithification in the concretion may reflect the temporal change in the composition of the sediments on the sea floor as well as diagenetic overgrowths associated with concretion formation.

Methane seep deposits occur in close association with the bedded sandstone concretions, as

FIG. 5. Outcrops of the Pierre Shale and Fox Hills Formation near Glendive, Dawson County, Montana, on the northwestern end of the Cedar Creek Anticline. A. View looking upslope with a methane seep deposit in the foreground (lower left) at the base of the Baculites baculus Zone. The horizontal bars indicate the contact between the B. eliasi $(\mathrm{Be})$ and B. baculus $(\mathrm{Bb})$ zones, the base of the upper part of the B. baculus Zone ( $\mathrm{uBb}$ ), and the Fox Hills Formation. B. Outcrop of the lower part of the B. baculus Zone showing bedded, cone-incone sandstone concretions (bss), septarian barite concretions (sept), and scaphite concretions (scaph). The base of the upper part of the B. baculus Zone is just above the bentonite crest at the top of the photo. $C$. Outcrop showing the top of the B. eliasi Zone and lower part of the B. baculus Zone with bedded sandstone concretions in the foreground (lower left). Arrows indicate small white concretions in the gray fissile shale surrounding and above the concretionary sandstone layer. D. Endocostea typica (arrow) in a sandstone concretion (length of specimen $=6 \mathrm{~cm}$ ). The matrix immediately surrounding the specimen of E. typica is different from the matrix of the rest of the concretion; hence, possibly, a concretion within a concretion. E. Cut-bank exposure of the B. eliasi Zone showing numerous bentonites. Several Fe-Mn and limestone concretions are visible. F. Close-up of a Fe-Mn concretion in the cut-bank shown in E. 
described in Landman et al. (2019) and Grier et al. (2019). We have documented more than five such deposits, each of which is limited in extent, ranging from 1 to $3 \mathrm{~m}$ in diameter (fig. 5A). The deposits consist of hard, vuggy limestone, weathering out from the surrounding darker shale. Ryan et al. (in press) examined one of these deposits in detail and analyzed the paleoecologic composition of the fossil assemblage. They reported that most of the species consist of infaunal suspension feeders dominated by lucinid bivalves. Specimens of Hoploscaphites are present, albeit rare, but specimens of Baculites are absent altogether.

Approximately $3 \mathrm{~m}$ above the bedded sandstone concretions is a layer of richly fossiliferous limestone concretions that Bishop $(1967,1973)$ called the "scaphite concretions," which are the source of many of the scaphites used in this study. The scaphite concretions are overlain by a $2 \mathrm{~m}$ thick interval of "bentonitic shale" capped by a 7-12 cm thick bentonite. This layer of bentonitic shale is a prominent feature of the landscape on the Cedar Creek Anticline. It has been referred to as a "bentonitic shale" due to the fact that the outcrop is covered with bentonite weathering down from above (Bishop, 1967, 1973; Linn 2010; Landman et al., 2019; Grier et al., 2019). It is also possible that the shale itself contains traces of ash, but this requires further study.

The lowest layer of concretions above the bentonite contains "Inoceramus" incurvus Meek and Hayden, 1856, which marks the base of the "I." incurvus Zone (= base of the upper part of the Baculites baculus Zone) (figs. 4,5A). The sediments coarsen upward toward the top of the Pierre Shale, which consists of a $3 \mathrm{~m}$ thick interval of silty shale. Gray limestone concretions contain specimens of Baculites grandis Hall and Meek, 1855, and, more rarely, Trachoceramus radiosus (Quaas, 1902), marking the base of the B. grandis and T. radiosus zones, respectively.

As noted above, most of the specimens of Hoploscaphites in our study are from the scaphite concretions in the lower part of the Baculites baculus Zone. We tabulated the biostratigraphic distribution of a subsample of 53 specimens from the Cedar Creek Anticline that were collected with tight stratigraphic control (fig. 4). We divided them into the $B$. eliasi, lower $B$. baculus, upper $B$. baculus, and lower B. grandis zones. Of 21 specimens of $H$. crassus, 1 occurs in the $B$. eliasi Zone and 20 in the lower B. baculus Zone. Of 20 specimens of $H$. plenus, 12 occur in the lower B. baculus Zone, 7 in the upper B. baculus Zone, and possibly 1 in the lower $B$. grandis Zone. Of 12 specimens of $H$. peterseni, 7 occur in the lower $B$. baculus Zone, 4 in the upper $B$. baculus Zone, and possibly 1 in the lower $B$. grandis Zone. Whether these numbers are an indication of actual abundance or simply a reflection of taphonomic bias is unknown, but probably a bit of both.

Age of the Baculites baculus Zone: The bentonite at the top of the "bentonitic shale" occurs at the boundary between the lower and upper parts of the Baculites baculus Zone (figs. 4, $5 B$ ). One of us (TL) excavated the outcrop to expose fresh material, which was bagged immediately for later analysis. Sanidine was isolated from the bentonite using standard magnetic and density separation techniques and verified using a variable pressure scanning electron microscope. Sanidine separates were irradiated along with the 28.201 Ma Fish Canyon sanidine standard (Kuiper et al., 2008) at the Oregon State University TRIGA reactor in the cadmium-lined in-core irradiation tube (CLICIT). Single crystal fusion experiments were performed with a $50 \mathrm{~W}$ $\mathrm{CO}_{2}$ laser in the WiscAr laboratory at the University of Wisconsin-Madison. Gas was analyzed using a Noblesse multi-collector mass spectrometer following the procedures in Jicha et al. (2016). Weighted mean ages were calculated using the decay constants of Min et al. (2000), and are reported with analytical uncertainties at the $95 \%$ confidence level.

Thirty single crystal fusion dates from the bentonite in the Baculites baculus Zone yielded a weighted mean ${ }^{40} \mathrm{Ar} /{ }^{39} \mathrm{Ar}$ age of $71.96 \pm 0.08 \mathrm{Ma}$ (supplementary fig.1; supplementary table 1: https://doi.org/10.5531/sd.sp.45). The nine young- 

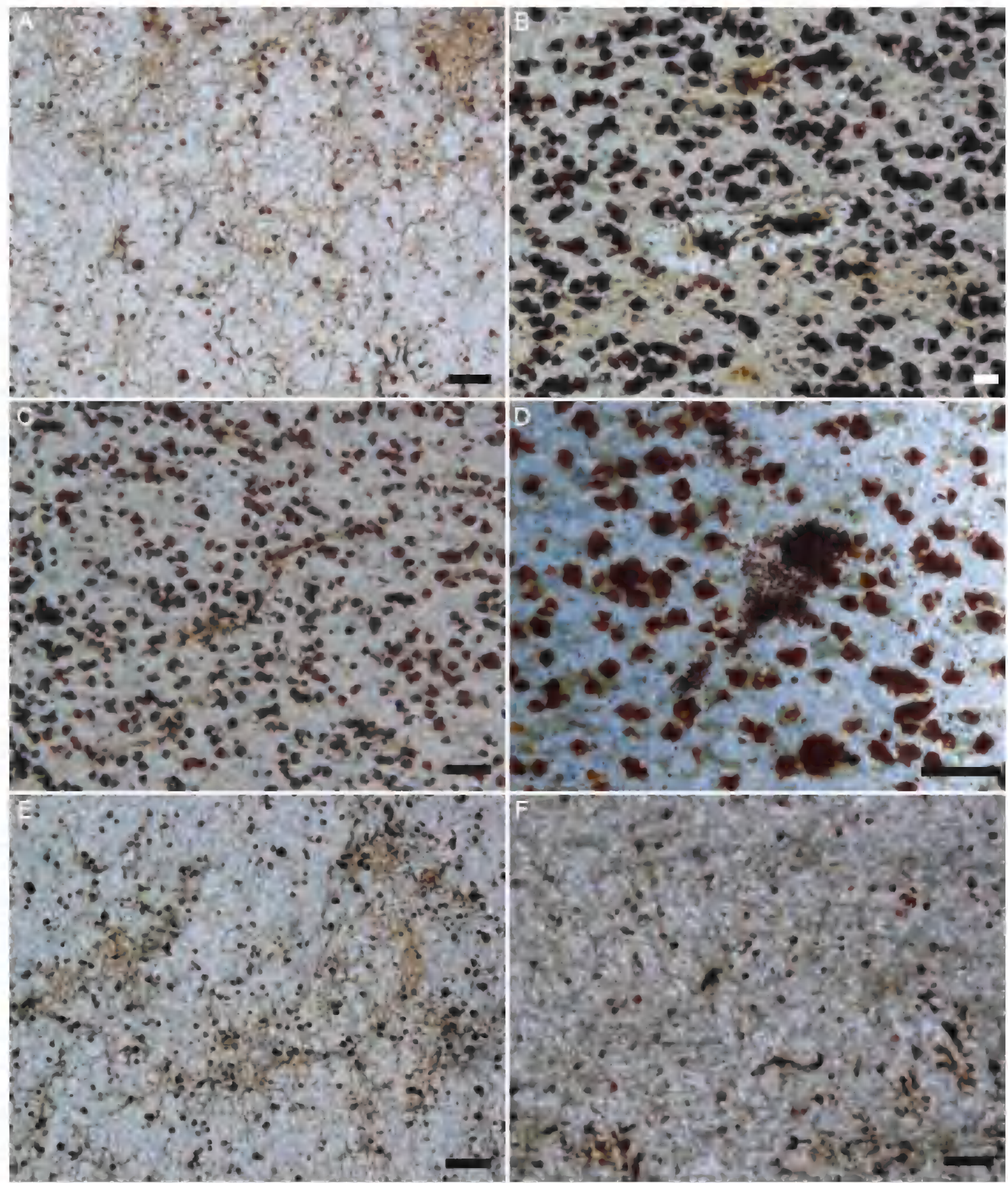

FIGURE 6. Petrographic thin sections of a bedded sandstone concretion from the base of the Baculites baculus Zone of the Pierre Shale, Dawson County, Montana. A. Upper part of the concretion. B. Upper-middle part of the concretion, showing a possible fecal pellet (center). C. Lower-middle part of the concretion. D. Cluster of ferruginous grains in dark-field view from the lower-middle part of the concretion. E, F. Mud from the lowest part of the concretion. Scale bar $=200 \mu$. 
est single crystal fusion dates from the B. eliasi Zone in Garfield County, Montana (Cobban et al., 2006), yielded a weighted mean ${ }^{40} \mathrm{Ar} /{ }^{39} \mathrm{Ar}$ age of $72.47 \pm 0.07 \mathrm{Ma}$. Our new age for the B. eliasi Zone is indistinguishable from the age of $72.50 \pm 0.31 \mathrm{Ma}$ that was originally reported in Cobban et al. (2006) and subsequently recalculated in Landman et al. (2018b: fig. 1). These two new ages from the middle of the B. baculus Zone and the B. eliasi Zone bracket the Campanian/Maastrichtian boundary, and are consistent with its previously reported age of 72.1 $\pm 0.2 \mathrm{Ma}$ (Lynds and Slattery, 2017).

Environment of Deposition: The environment of deposition of the scaphite concretionary horizon in the lower Baculites baculus Zone of the Pierre Shale on the Cedar Creek Anticline has recently been studied by Landman et al. (2015b). During the early Maastrichtian, the shoreline of the WIS was approximately $80 \mathrm{~km}$ to the south along the margin of the Sheridan Delta, as described by Reiskind (1975). The depth of the WIS at this site was approximately $50 \mathrm{~m}$ (Landman et al., 2018a). A high incidence of freshwater fungae was not reported from slightly older deposits (B. compressus Zone) of the Bearpaw Shale of north-central Montana, suggesting a source of riverine input in the area (Palamarczuk and Landman, 2011).

The sediments in the scaphite concretionary horizon consist of dark, silty mudstone indicative of a soft muddy bottom. The mudstone is finely bioturbated, suggesting that the sediments were well oxygenated. No primary sedimentary structures are visible, although they may have been destroyed by bioturbation. If they were not destroyed, their absence suggests a lack of currents on the bottom. The rate of sedimentation was probably high, based on the preservation of numerous cephalopod jaws (see below). The preservation of cephalopod jaws is usually interpreted as an indicator of rapid sedimentation and burial because, according to modern experiments, these structures begin to disintegrate after a few years on the sea floor (see Kear et al., 2015). In addition, most of the phragmocones of the ammonites are hollow or filled in with secondary calcite rather than sedimentary matrix. Equally, the apical whorls of gastropods are filled in with secondary calcite instead of matrix, suggesting that they were also rapidly buried before they could be filled in with resuspended sediment.

Landman et al. (2015b) investigated a single concretion from the scaphite concretionary horizon (cover photo). It contains both nekton and benthos. Among the nekton, are approximately 90 specimens of scaphites, most of which belong to Hoploscaphites crassus. The majority of these specimens are adults (see fig. 7), although a few smaller specimens are also present. Only 10 specimens of Baculites are present, all of which are fragments of juveniles. Landman et al. (2015b) also recorded a single coleoid gladius. In addition, the concretion contains 35 cephalopod jaws, nearly all of which are attributed to Hoploscaphites. The only other evidence of nekton is a couple of fish bones.

In terms of benthos, the scaphite horizon is dominated by molluscs. Not surprisingly, given the soft substrate, most of the bivalves are infaunal and include Nucula, Nuculana, and Yoldia. The epifauna include Pecten (Chlamys), Oxytoma, Anomia, and Endocostea. Gastropods are dominated by carnivores/scavengers and include Drepanochilus. Of the other fauna, scaphopods are represented by two species, both of which are semiinfaunal carnivores, Landman et al. (2015b) also noted the presence of a few echinoids, bryozoans, and corals.

Because several of the ammonite shells were very well preserved, they were utilized for isotopic analysis to infer the temperature of the bottom water. In the two best-preserved specimens of Hoploscaphites plenus, the average value of $\delta^{18} \mathrm{O}$ is $-2.12 \%$ (Landman et al., 2015b: table 4). Assuming that the ammonites secreted their shells in isotopic equilibrium with seawater, as in modern nautilus (Landman et al., 1994), and that the scaphites lived near the bottom (Landman et al., 2012), these values reflect the ambient temperature. Using the aragonite-temperature equation of Grossman and $\mathrm{Ku}$ (1986), and assuming an average value of $\delta^{18} \mathrm{O}$ of Cretaceous sea water of $-1.0 \%$ (Shackleton and Kennett, 1975; Dennis et al., 2013), the average value of 


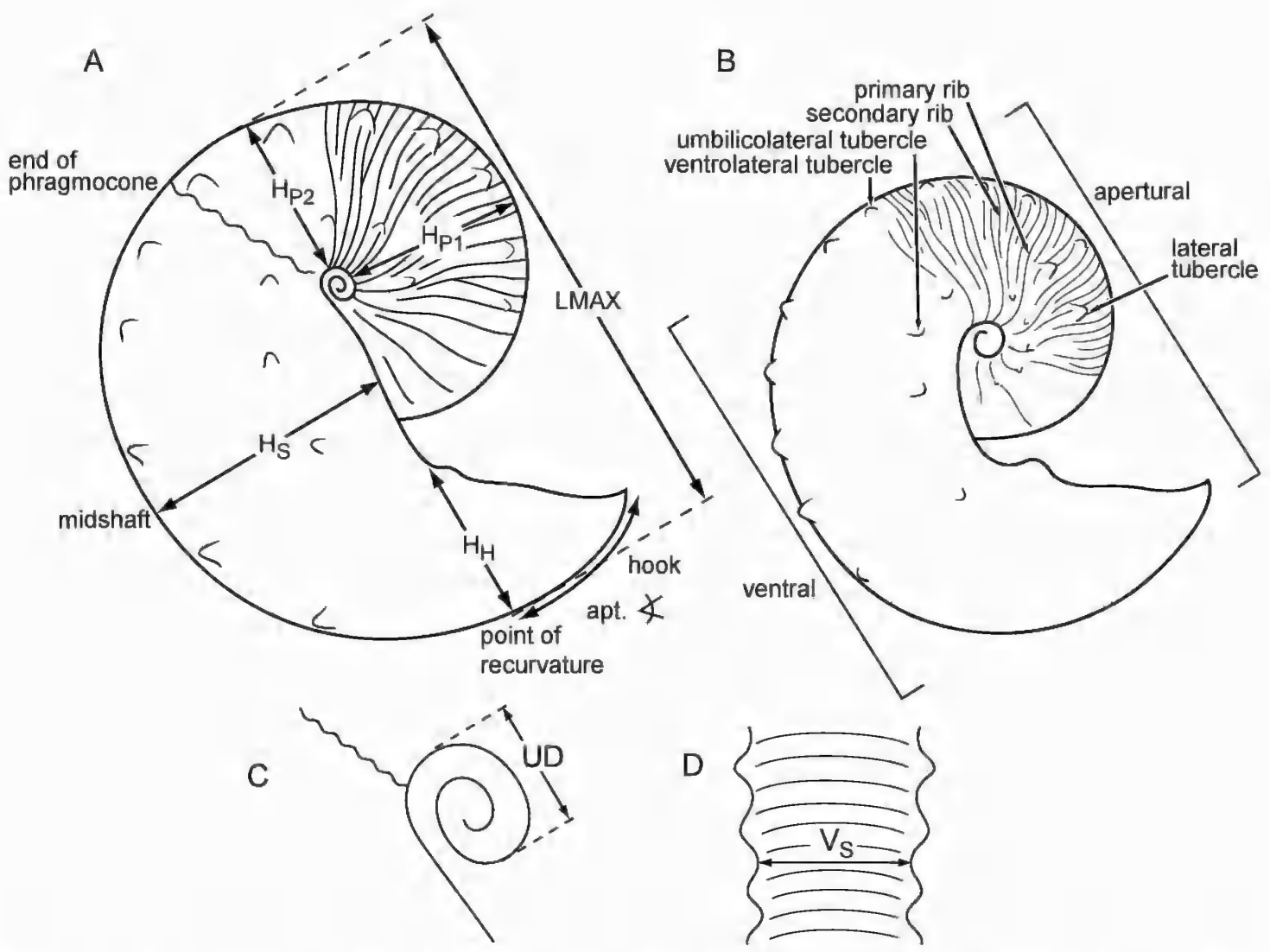

FIGURE 7. Scaphite terminology (after Landman et al., 2013: 9, fig. 3). A. Macroconch adult, right lateral view. Abbreviations: $\mathrm{H}_{\mathrm{H}}=$ whorl height at the point of recurvature; $\mathrm{H}_{\mathrm{p}_{1}}=$ whorl height at the adapical end of the phragmocone; $\mathrm{H}_{\mathrm{p} 2}=$ whorl height at the adoral end of the phragmocone; $\mathrm{H}_{\mathrm{S}}=$ whorl height at midshaft; LMAX = maximum length along the long axis; apt. $<$ ) = apertural angle. B. Microconch adult, right lateral view. Specimens were photographed from the right lateral, left lateral, ventral, and apertural directions. C. Close-up of the umbilicus of the macroconch showing the umbilical diameter measured parallel to the long axis (UD). D. View of the venter of the body chamber at midshaft, with the adoral direction toward the top, showing the width of the venter $\left(\mathrm{V}_{\mathrm{S}}\right)$, as measured between the ventrolateral margins.

$\delta^{18} \mathrm{O}$ of the two best-preserved samples equates to $27.0^{\circ} \mathrm{C}$. This value is similar to temperatures calculated by Landman et al. (2018a) for the upper Baculites baculus and lower B. grandis zones of the Pierre Shale at the same site. It is also nearly identical to the average temperature calculated by Kruta et al. (2014) for the slightly older upper Campanian Baculites sp. smooth Zone of the Pierre Shale in South Dakota based on ammonite shells and aptychi.

PREDATION: Injuries due to predatory damage are common in the scaphite concretionary hori- zon in the lower Baculites baculus Zone of the Pierre Shale. Unrepaired injuries indicate that the anaimals died as a result of the attacks. Such injuries are manifested by missing pieces of shell, usually on the adapical end of the body chamber. Keupp (2006) referred to these injuries as "forma aegra fenestra" because of their resemblance to windowlike openings. The consistent position of these injuries is a clue that they occurred during the lifetime rather than after the death of the animal (Radwański, 1996; Larson, 2003, 2007; Keupp, 2006; Klompmaker et al., 2009). 

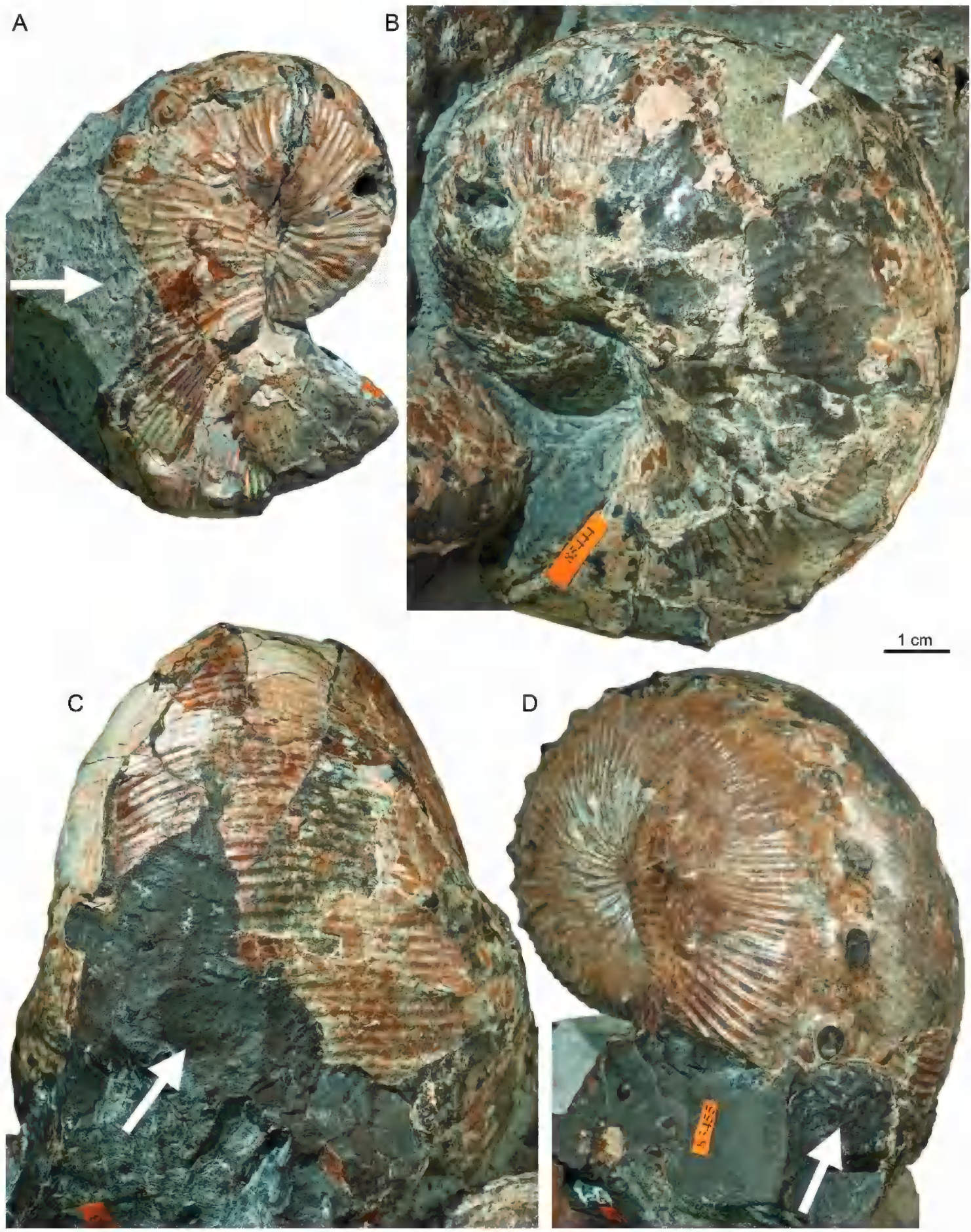
The scaphite concretionary horizon contains many examples of such injuries. In AMNH 85450 (fig. 8C), a macroconch of Hoploscaphites crassus, part of the shell is missing along the venter starting in the shaft and extending to the hook, leaving a hole with jagged edges. In AMNH 85444 (fig. 8B), another macroconch of $H$. crassus, a hole appears on the adapical end of the body chamber. It is $25 \mathrm{~mm}$ in diameter with jagged edges. Similarly, in AMNH 85473 (fig. 8A), a macroconch of $H$. peterseni, a chunk of shell is missing from the right side and venter of the shaft.

The position of these injuries on the venter and ventrolateral flanks on the adapical end of the body chamber indicates that the scaphites were attacked from behind (Larson, 2003; Landman et al., 2012). Such an attack would have allowed the predator to gain access to the muscles and viscera of the animals. These attacks would have come as an unwelcome surprise to the scaphites because their eyes were probably located on the other side of the shell in the pair of reentrants along the apertural margin. The attacks would also have been fatal to the scaphites because the injuries were too far back from the mantle edge to be repaired (Landman and Waage, 1986; Kröger, 2002a, 2002b; Klompmaker et al., 2009). Possible predators included fish, turtles or other reptiles, crustaceans, and coleoids (Landman and Waage, 1986; Larson, 2003; Keupp, 2006; Klompmaker, 2009).

SCAPHITE JAWs: ONE of the conspicuous features in the scaphite concretionary horizon, as noted above, is the high incidence of scaphite jaws (figs. 9, 10C, D). In contrast, such jaws are rare in the upper part of the B. baculus Zone and are absent altogether in the $B$. grandis Zone. The jaws in the scaphite concretionary horizon occur either inside the body chamber or in close juxta- position with the ammonite (figs. 9A-F, 10C, D). Lower jaws are much more common than upper jaws (Landman et al, 2015b). This preservational bias possibly reflects the larger size and bulkier shape of the lower jaws.

The morphology of these jaws is similar to that of the jaws described by Landman et al. (2010: 55-62) from the Baculites compressus-B. cuneatus zones of the Pierre Shale. The upper jaw is U-shaped with two narrow wings that converge anteriorly to a beaklike apex (fig. 9G). Usually, only the anterior tip of the upper jaw is preserved. The lower jaw is convex and consists of two wings in mirror image that meet along a plane of bilateral symmetry called the commissure (fig. 9D-F). The commissure is bordered by a flange on each side, which reaches its maximum height just before the posterior margin. The apex is weakly projected forward, and the anterior margin is slightly concave on either side.

Each wing of the lower jaw is composed of two layers: (1) an inner layer of black material, approximately 40 um thick, which presumably represents diagenetically altered chitin and (2) an outer layer of calcite known as the aptychus, approximately $100 \mathrm{um}$ thick (fig. 9J) (for further discussion of the microstructure of the outer layer, see Kruta et al., 2009). The ventral surface of the aptychus is ornamented with growth lines and fine lirae that parallel the lateral and posterior margin. In jaws from the scaphite concretionary horizon, the black layer of the lower jaw is much more commonly preserved than the calcitic layer. The rarity of the calcitic layer is probably due to mechanical damage or chemical dissolution prior to the formation of the enclosing concretion (for a discussion on the diagenetic disappearance of the calcitic layer, see Landman et al., 2006).

FIGURE 8. Lethal injuries in Hoploscaphites, AMNH loc. 3921, scaphite concretionary horizon, lower Baculites baculus Zone, Pierre Shale, Cedar Creek Anticline, east-central Montana. A. AMNH 85473, macroconch, Hoploscaphites peterseni, with a chunk of shell missing from the right side and venter of the shaft (arrow). B. AMNH 85444, macroconch, $H$, crassus, with a hole on the adapical end of the body chamber (arrow). C. AMNH 85450, macroconch, Hoploscaphites crassus, with part of the shell missing along the venter (arrow). D. AMNH 85455, macroconch, Hoploscaphites crassus, with shell damage on the adoral part of the body chamber (arrow). 

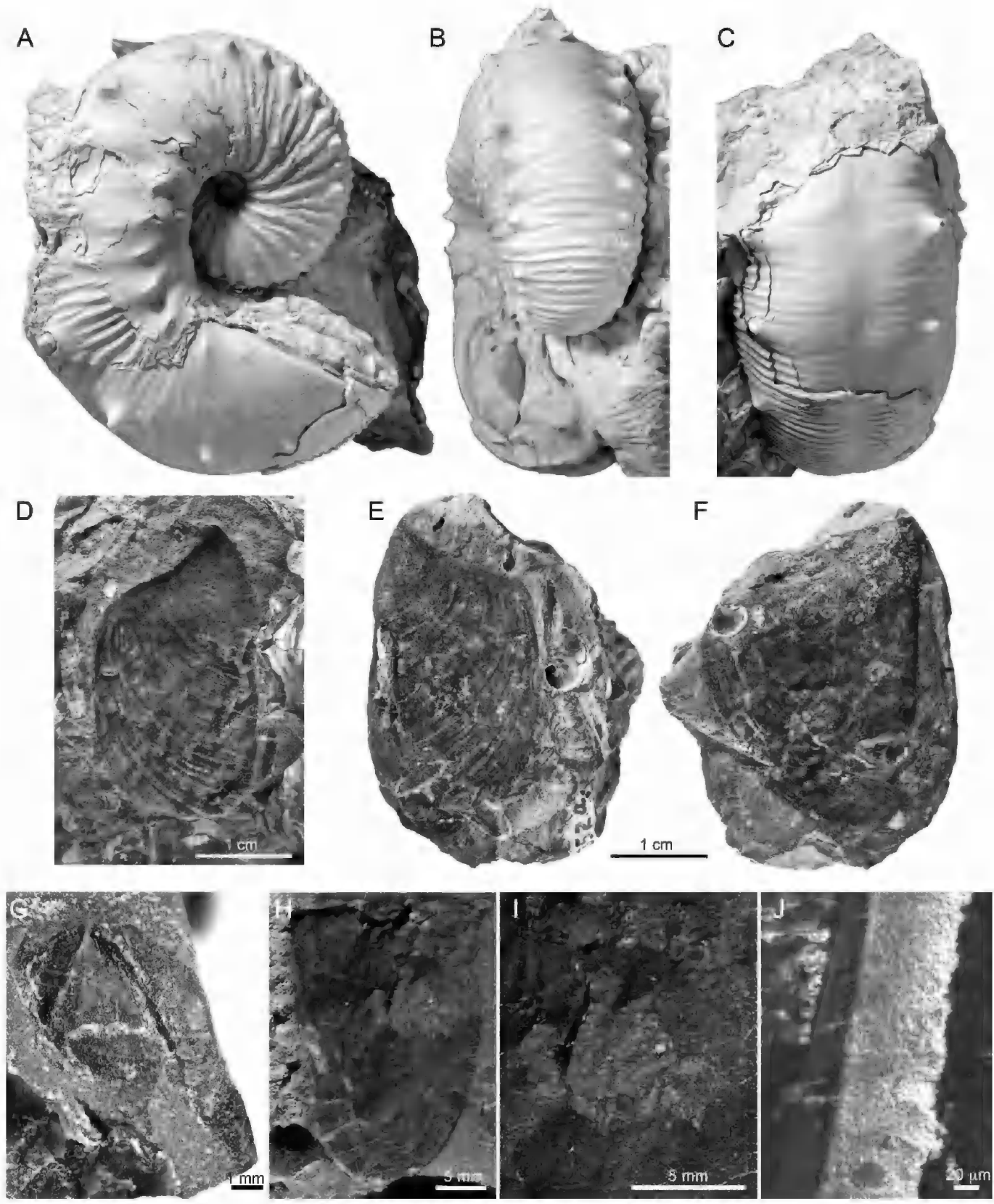

FIGURE 9. Jaws of Hoploscaphites, AMNH loc. 3921, lower Baculites baculus Zone, Pierre Shale, Cedar Creek Anticline, east-central Montana. A-F. Species closely related to Hoploscaphites crassus (Coryell and Salmon, 1934), microconch, AMNH 80109, with associated lower jaw (D-F). A. Right lateral; B. apertural; C. ventral, showing growth deformity manifested as a furrow along the midventer. D. Impression of the lower jaw. E. Left wing of the lower jaw. F. Right wing of the lower jaw. G. Tip of an upper jaw attributed to Hoploscaphites, dorsal view, AMNH 63600. H, I. Lower jaw attributed to H. crassus, AMNH 64498. H. Right lateral view, with hole. I. Close-up of hole. J. SEM of a lower jaw attributed to Hoploscaphites, AMNH 64512. The lower jaw consists of an inner black layer (left) originally composed of chitin, and a mineralized outer layer called the aptychus (right), originally composed of calcite. 
Some jaws show evidence of tearing, warping, and compaction, testifying to their residence time on the sea floor (for further details, see Environment of Deposition). In addition, several jaws, such as AMNH 64498 (fig. 9H, I), bear puncture marks that must have been produced by predation. Presumably, the predator crushed part or all of the body chamber and ingested the soft body including the jaws. The jaws would have subsequently been deposited as fecal matter after passing through the digestive track of the predator. Alternatively, the jaws could have been regurgitated by the predator because they were indigestible.

The incidence of scaphite jaws in the lower part of the Baculites baculus Zone on the Cedar Creek Anticline is similar to that in the Hoploscaphites nicolletii and $H$. nebrascensis zones of the Fox Hills Formation in north-central South Dakota (Landman and Waage, 1993). The incidence is higher than that in the $B$. compressus- $B$. cuneatus zones of the Pierre Shale in southwestern South Dakota (Landman et al., 2010; Landman and Klofak, 2012). Such differences may reflect variation in the rate of burial of shelly debris on the sea floor and the timing of formation of the surrounding concretions. Such differences may also reflect variation in the circumstances under which the particular animals died, and the length of time that they floated after death. In Hoploscaphites, the constricted aperture of the body chamber would have prevented the soft body from immediately falling out after death, favoring the preservation of jaws.

\section{TERMS AND METhods}

In our overview of morphological variation, evolutionary patterns, and systematic descriptions, we utilize a number of terms to describe scaphite morphology, specifically as they apply to Hoploscaphites. The adult shell of Hoploscaphites consists of a closely coiled phragmocone and a slightly to strongly uncoiled body chamber (fig. $7 \mathrm{~A}, \mathrm{~B}$ ). The adult phragmocone is the part of the phragmocone that is exposed in the adult shell.
The point of exposure is the most adapical point of the adult phragmocone. An unpaired muscle scar appears on the venter just adoral of the end of the phragmocone (fig. $10 \mathrm{~A}, \mathrm{~B})$. It is small (2-5 $\mathrm{mm}$ in maximum length, depending on the size of the specimen) and oval in shape. The body chamber consists of the shaft, beginning at the last septum, and a hook terminating at the aperture. The point of recurvature is the point at which the adapertural part of the body chamber recurves dorsally.

Measurements of the adult shell are illustrated in figure 7. All measurements were made using electronic calipers on actual specimens, rather than on photos.

Maximum length of the adult shell (LMAX) = the length from the venter of the adult phragmocone to the venter of the hook

Umbilical diameter of the adult shell (UD) $=$ the diameter of the umbilicus parallel to the line of maximum length

$\mathrm{W}=$ maximum whorl width

$\mathrm{H}=$ maximum whorl height measured from the umbilical seam to the midventer

$\mathrm{W}_{\mathrm{P} 1}, \mathrm{H}_{\mathrm{P} 1}=$ whorl width and whorl height, respectively, at the adapical end of the adult phragmocone, $90^{\circ}$ adapical of the line of maximum length

$\mathrm{W}_{\mathrm{P} 2}, \mathrm{H}_{\mathrm{P} 2}=$ whorl width and whorl height, respectively, at the adoral end of the adult phragmocone, along the line of maximum length

$\mathrm{W}_{\mathrm{S}}, \mathrm{H}_{\mathrm{S}}=$ whorl width and whorl height, respectively, at the midshaft of the body chamber

$\mathrm{W}_{\mathrm{H}}, \mathrm{H}_{\mathrm{H}}=$ whorl width and height, respectively, at the point of recurvature

$V_{S}=$ width of the venter at midshaft between ventrolateral margins on opposite sides of the venter.

In describing specimens, we note the whorl height at which maximum whorl width occurs. For example, the statement that maximum whorl width occurs at $1 / 3$ whorl height means that it occurs at $1 / 3$ whorl height from the umbilical 
seam. We calculated several ratios to describe the shape of the adult shell and facilitate comparisons among specimens. The ratios of whorl width to whorl height were calculated at four points on the shell $\left(\mathrm{W}_{\mathrm{P} 1} / \mathrm{H}_{\mathrm{P} 1}, \mathrm{~W}_{\mathrm{P} 2} / \mathrm{H}_{\mathrm{P} 2}, \mathrm{~W}_{\mathrm{S}} / \mathrm{H}_{\mathrm{S}}\right.$, $\left.\mathrm{W}_{\mathrm{H}} / \mathrm{H}_{\mathrm{H}}\right)$, as described above, and provide a measure of the degree of whorl compression. The ratio of ventral width to whorl height at midshaft $\left(\mathrm{V}_{\mathrm{S}} / \mathrm{H}_{\mathrm{S}}\right)$ provides an additional measure of the degree of whorl compression. The inverse of this ratio $\left(\mathrm{H}_{\mathrm{S}} / \mathrm{V}_{\mathrm{S}}\right)$ expresses the relationship between the height of the whorl and the width of the venter, so that a value of 1.5 implies that the height of the whorl is $1.5 \times$ the width of the venter.

The ratio of maximum length to whorl height of the phragmocone along the line of maximum length $\left(\mathrm{LMAX} / \mathrm{H}_{\mathrm{P} 2}\right)$ is a measure of the degree of uncoiling. The ratio of maximum length to whorl height at midshaft in macroconchs $\left(\mathrm{LMAX} / \mathrm{H}_{\S}\right)$ is a measure of the degree of curvature of the body chamber in lateral view. This ratio applies only to macroconchs because the umbilical shoulder of the body chamber in these forms usually coincides with the line of maximum length, and thus the whorl height $\left(\mathrm{H}_{\mathrm{S}}\right)$ is the distance from the line of maximum length to the venter of the body chamber (equivalent to the radius in the case of a semicircle). The apertural angle was measured on photographs of specimens in lateral view. A line was drawn along the umbilical shoulder and another line was drawn along the apertural margin. The apertural angle is the angle of intersection between these two lines, extending from approximately the point of recurvature to the aperture. This measurement applies only to macroconchs.

The terms used to describe ornamentation were reviewed by Landman et al. (2019). Primary ribs originate near the umbilicus, whereas secondary ribs originate on the flanks or venter, either by branching or intercalation. The density of ribs was measured by counting the number of ribs/cm on the venter at four points on the adult shell: (1) the adapical end of the phragmocone, (2) the adoral end of the phragmocone, (3) the midshaft, and (4) the hook. In addition to ribs, the ornamentation consists of tubercles. Umbilicolateral tubercles occur near the umbilicolateral margin, ventrolateral tubercles near the ventrolateral margin, and lateral tubercles on the flanks (fig. 7). The statement that ventrolateral tubercles occur at $7 / 8$ whorl height means that they occur at $7 / 8$ whorl height from the umbilical seam. We recorded the number of ventrolateral, umbilicolateral, and lateral tubercles on the phragmocone and body chamber of the adult shell, in addition to the distances between tubercles, following the curvature of the shell. We also noted the size and shape of the tubercles as well as the number of ribs that join a tubercle dorsally and the number of ribs that branch from it ventrally.

\section{INTRA- AND INTERSPECIFIC VARIATION}

In this study, we followed a traditional typological approach in defining species. Our collections consist of large numbers of well-preserved specimens that retain their original dimensions, allowing precise measurements and detailed examination of their morphology. In addition, many specimens are derived from single horizons from the same area, providing snapshots, albeit blurry, of living populations (for a recent discussion of time averaging, see Foote et al., 2007). In describing species, we rely on all morphological traits, including ornamentation, shell shape, size, and sutures. The fact that the mature stage of Hoploscaphites is well defined due to the uncoiling of the body chamber permits an unequivocal separation of variation due to ontogeny (different developmental stages) from phenotypic variation among adults.

One source of adult variation is sexual dimorphism. In general, ammonite dimorphs are referred to as macroconchs and microconchs. Following the traditional view, macroconchs are interpreted as females and microconchs as males (Lehmann, 1981; Davis et al., 1996; Klug et al., 2015). The dimorphs of Hoploscaphites are distinguished by differences in size and morphology 
(fig. 7A, B). Macroconchs usually attain a larger size than microconchs, but the size range of the two dimorphs overlap (Landman et al., 2010). The outline of the umbilical shoulder of the body chamber relative to that of the venter in side view is a reliable means of distinguishing dimorphs. The umbilical shoulder of the body chamber is straight in macroconchs whereas it is curved in microconchs, following the outline of the venter. In addition, the umbilical wall is nearly flat and subvertical in macroconchs whereas it is broad and outwardly sloping in microconchs.

Another source of variation is size at maturity within each dimorph. For example, we have observed a wide range of variation in the size of adult macroconchs of Hoploscaphites crassus and $H$. plenus. In $H$. crassus, the size of the smallest macroconch is $67.7 \mathrm{~mm}$ and the size of the largest macroconch is $131.0 \mathrm{~mm}$. In $H$. plenus, the size of the smallest macroconch is $71.8 \mathrm{~mm}$ and the size of the largest macroconch is $130.7 \mathrm{~mm}$. Thus, in both of these species, the ratio of the size of the largest macroconch to that of the smallest is nearly two times. Landman et al. (2010) observed a similar size difference in species of Hoploscaphites from the Baculites compressus- $B$. cuneatus zones of the Pierre Shale. Such variation may reflect differences in the age at which individuals mature. If all specimens grew at approximately the same rate, smaller specimens would have attained maturity at younger ages (for an extended discussion about size-age variation, see deBaets et al., 2015).

In addition to variation within species, we have observed broad variation between species. In many instances, a single specimen is intermediate between two species. For example, some of the specimens in our collection exhibit a broadly inflated whorl section and were, therefore, attributed to Hoploscaphites crassus. However, the ventrolateral tubercles on the body chamber are large and widely spaced, more closely resembling the pattern in $H$. plenus. Similar examples of intermediate specimens exist between $H$. crassus and $H$. peterseni and between $H$. peterseni and $H$. plenus. One possible explanation for this pattern is that all three species represent one biological species with a broad range of intraspecific variation or, alternatively, three subspecies within a single species. We treat them as three separate species because intermediate specimens are relatively rare and because the three species can be readily distinguished from each other based on the diagnoses outlined below.

It is also possible that these three species represent a "flock" of very closely related forms, similar to the "species flocks" observed in modern cichlid fishes (for a discussion about this phenomenon, see Salzburger et al., 2002). Indeed, all three species lived at the same time and inhabited the same geographic area. In addition, all of them share a similar pattern of ornamentation consisting of long, thin, nonbifurcating ribs on the adoral part of the phragmocone, suggesting that they constitute a single monophyletic clade. They differ in the degree of whorl compression and the size and spacing of ventrolateral tubercles. This concept of species flocks has, in fact, been used to explain the explosive radiation of acanthoceratid ammonites in the WIS, as mediated by heterochronic change (Yacobucci, 1999). It may equally apply to the origin of these three species of Hoploscaphites during the early Maastrichtian, following an episode of global cooling. However, the isolation mechanisms that served to separate populations and promote speciation remain obscure (e.g., sea level change, formation of isolated embayments, etc.).

\section{Evolutionary Patterns}

The diversity of morphological characters in Hoploscaphites include shell size, shell shape, ornamentation, degree of uncoiling, and sutures, among others. All these features appear in multiple character states. For example, ventrolateral tubercles on the adult body chamber can be closely or widely spaced, small ( $2 \mathrm{~mm}$ high) or large (6 mm high), conical or clavate, etc. Ribs can be rursiradiate, rectiradi- 
ate, or prorsiradiate. In addition, the various character states for any particular character can occur in combination with different character states for other characters, leading to varied and novel permutations. For example, small ventrolateral tubercles can cooccur with inflated whorl sections or compressed whorl sections. Large ventrolateral tubercles can cooccur with fine, closely spaced ribs or coarse, widely spaced ribs. This panoply of combinatorial outcomes produces a seemingly endless variety of forms building on a single theme.

Despite this variability, we have noted evidence of morphological integration, that is, the nonrandom, persistent cooccurrence of certain character states. In particular, we have noted a correlation between the degree of whorl compression/depression of the shell and the incidence of lateral tubercles. This is apparent in a comparison between macroconchs of Hoploscaphites crassus, $H$. plenus, and $H$. peterseni, on the one hand, and $H$. macer, $H$. criptonodosus, and $H$. sargklofak, on the other hand. The first three species are most abundant in the lower Baculites baculus Zone and the second set of species are most abundant in the upper B. baculus Zone and the B. grandis Zone.

The degree of whorl compression/depression of the shell is expressed by the ratio of whorl width to whorl height at midshaft $\left(\mathrm{W}_{\mathrm{S}} /\right.$ $\mathrm{H}_{\mathrm{S}}$ ). This ratio averages 1.31 in Hoploscaphites crassus (table 1), 1.09 in $H$. plenus (table 3), 0.99 in $H$. peterseni (table 5), 0.90 in H. criptonodosus (fig. 11), 0.81 in H. macer (fig. 11), and 0.70 in $H$. sargklofak (fig. 11). The ratio of ventral width to whorl height at midshaft $\left(V_{S} /\right.$ $\mathrm{H}_{\mathrm{S}}$ ) provides an additional measure of the degree of whorl compression/depression. This ratio averages 0.87 in $H$. crassus (table 1), 0.68 in $H$. plenus (table 3 ), 0.58 in $H$. peterseni (table 5), 0.43 in H. criptonodosus (fig. 11), 0.40 in H. macer (fig. 11), and 0.35 in H. sargklofak (fig. 11).

Lateral tubercles are rare or absent on shells of Hoploscaphites crassus, $H$. plenus, and $H$. peterseni (fig. 11). A maximum of two tubercles have been reported in each of these species (Meek, 1876; Riccardi, 1983). The two tubercles occur on the adapical end of the phragmocone. A single row of five lateral tubercles has been reported in $H$. macer (fig. 11). They appear on the adapical end of the phragmocone and persist for $1 / 8$ whorl (Landman et al., 2019). In contrast, lateral tubercles are common on the shells of $H$. criptonodosus and H. sargklofak (fig. 11). In $H$. criptonodosus, two rows of lateral tubercles with a combined total of 12 tubercles are present on the adapical part of the exposed phragmocone and persist for as much as $1 / 2$ whorl (Landman et al., 2019). In H. sargklofak, two rows of lateral tubercles, with a combined total of 13 tubercles, are present on the exposed phragmocone (Landman et al., 2015a). In addition, a single row of as many as five lateral tubercles extends from the adoral end of the shaft to the aperture, so that the total of lateral tubercles on the exposed shell of this species is 18.

The plot of $\mathrm{W}_{\mathrm{S}} / \mathrm{Hs}$ vs $\mathrm{V}_{\mathrm{S}} / \mathrm{H}_{\mathrm{S}}$ for these six species is shown in figure $11 \mathrm{~A}$. The shape of the shell is more compressed in geologically younger species. In addition, the degree of shell compression is correlated with the number of lateral tubercles (fig. 11B). This correlation is not random but undoubtedly mirrors

FIGURE 10. A, B. Unpaired muscle scar just adoral of the last suture. The adoral direction is toward the bottom. A. Hoploscaphites peterseni, macroconch, USNM 723219, USGS loc. 22142, Baculites eliasi Zone, Bearpaw Shale, Valley County, Montana. B. H. macer Landman et al., 2019, microconch, AMNH 69736, AMNH loc. 3921, upper B. baculus or lower B. grandis Zone, Pierre Shale, Cedar Creek Anticline, east-central Montana. C, D. Hoploscaphites plenus (Meek and Hayden, 1860), AMNH 135082, with lower jaw in the body chamber, AMNH loc. 3921, lower Baculites baculus Zone, Pierre Shale, Cedar Creek Anticline, east-central Montana. C. Left lateral view. D. Close-up of the lower jaw. 

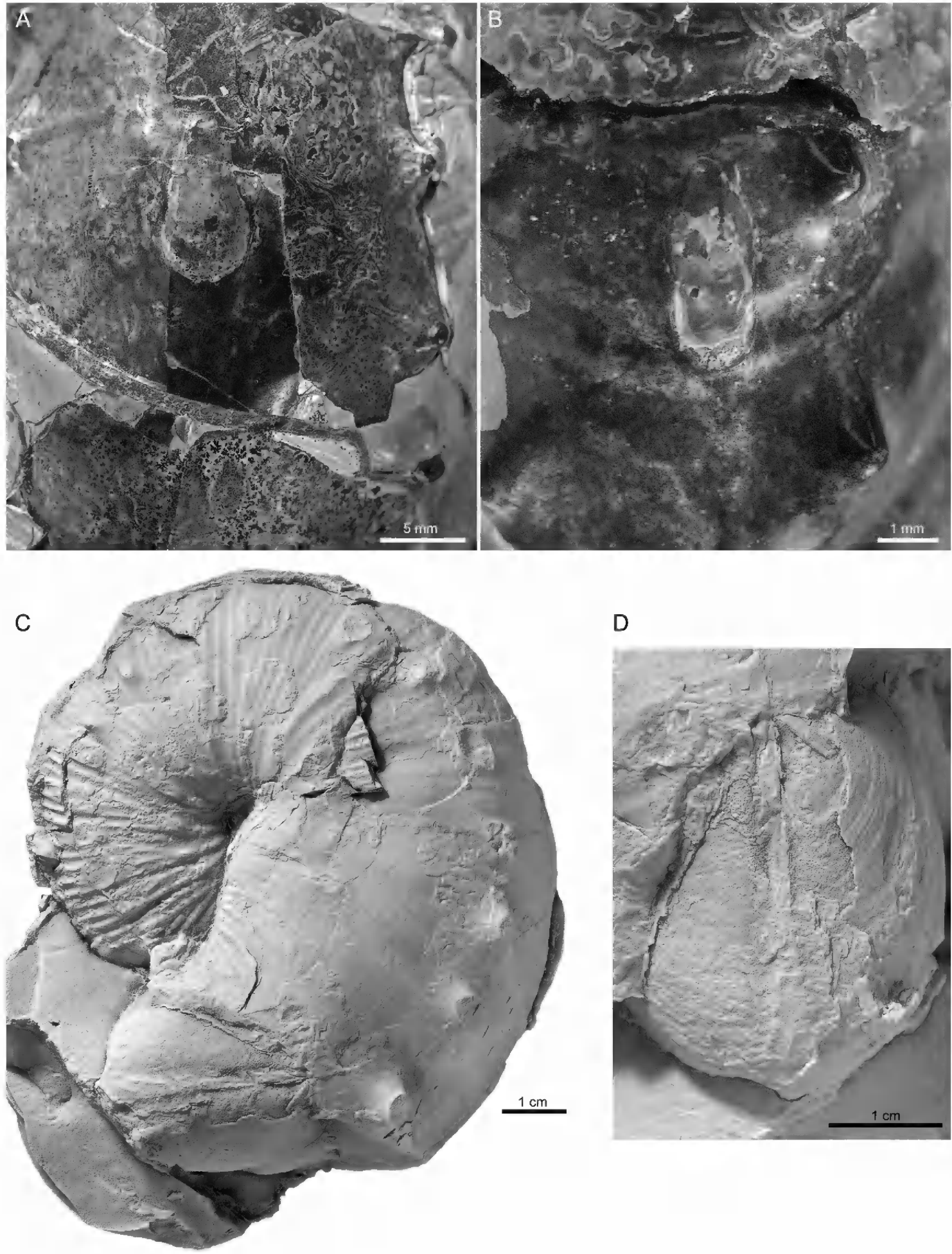

D

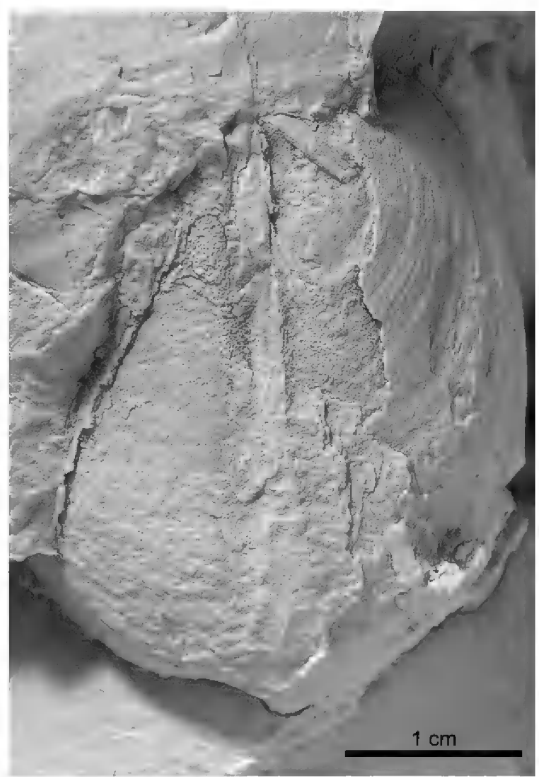


the change in habitat associated with the appearance of the new species. As noted above, the transition from the Baculites eliasi to $B$. grandis zones at Red Bird, Wyoming, and the Cedar Creek Anticline, Montana, corresponds to a change to a higher energy, more nearshore environment, reflecting the progressive migration of the western shoreline of the WIS toward the east (fig. 1). The more compressed shell shapes of Hoploscaphites criptonodosus, $H$. macer, and H. sargklofak would have been more advantageous in such an environment compared to the more depressed shell shapes of $H$. crassus, $H$. plenus, and $H$. peterseni (for a recent discussion of hydrodynamics in ammonites, in general, see Naglik et al., 2015, and in scaphites, in particular, see Peterman et al., 2020). Similarly, the increased tuberculation in the geologically younger species may also be related to the transition to a more nearshore environment, with a simultaneous increase in the number and kinds of predators. The acquisition of lateral tubercles would have provided additional protection against such predators, as suggested by Landman and Waage (1986, 1993), Landman et al. (2010), and Takeda et al. (2016).

\section{REPOSITORIES}

The repository of specimens described in the text is indicated by a prefix, as follows: Department of Invertebrate Paleontology, American Museum of Natural History (AMNH), New York; Academy of Natural Sciences of Drexel University (ANSP); Black Hills Institute of Geological Research (BHI), Hill City, South Dakota; the Field Museum (FMNH), Chicago, Illinois; Geological Survey of Canada (GSC), Ottawa, Canada; Rutgers University Geological Museum (RUGM), New Brunswick, New Jersey; Yale Peabody Museum (YPM), New Haven, Connecticut; and U.S. National Museum (USNM), Washington, D.C. The localities of the specimens are listed in the appendix.

\section{SYSTEMATIC PALEONTOLOGY}

Class Cephalopoda Cuvier, 1797

Order Ammonoidea Zittel, 1884

Suborder Ancyloceratina Wiedmann, 1966

Superfamily Scaphitoidea Gill, 1871

Family Scaphitidae Gill, 1871

Subfamily Scaphitinae Gill, 1871

Genus Hoploscaphites Nowak, 1911

[= Mesoscaphites Atabekian, 1979: 523 (nomen nudum) fide Kennedy, 1986; Wright, 1996; Jeletzkytes Riccardi, 1983: 14]

Type Species: Ammonites constrictus J. Sowerby (1817: 189, pl. A, fig. 1), by original designation.

DiAgnosis: "Small to large scaphites, strongly dimorphic, with broad variation in degree of whorl compression ranging from slender to robust, with involute phragmocone, short to long shaft, and weakly recurved hook; apertural angle ranging from approximately $35^{\circ}$ to $85^{\circ}$; aperture constricted with dorsal projection; ribs straight to flexuous, increasing by branching and intercalation, with weak to strong adoral projection on venter; adult shell with or without umbilicolateral, flank, and ventrolateral tubercles; suture fairly indented, with symmetrically to slightly asymmetrically bifid first lateral lobe" (Landman et al., 2010: 93).

\section{Hoploscaphites crassus \\ (Coryell and Salmon, 1934)}

Figures 9H, I, 10B-D, 12-31, 32A, B, 33-40

Macroconch Synonomy

1885. Scaphites subglobosus. Whiteaves, p. 52

(pars), pl. 8, fig. 2 only; non pl. 7, fig. 3; non pl. 8 , fig. 1.

1917. Scaphites subglobosus Whiteaves. Dowling, p. 32 (pars), pl. 31 , fig. 2 only (= Whiteaves, 1885, pl. 8 , fig. 2); non pl. 31, fig. 1. 
1934. Acanthoscaphites nodosus crassus. Coryell and Salmon, p. 15, figs. 10, 11.

1934. Acanthoscaphites duplico-nodosus. Coryell and Salmon, p. 17, figs. 12, 13.

1983. Jeletzkytes crassus (Coryell and Salmon, 1934). Riccardi, p. 20, pl. 9, figs. 3, 4; textfigs. 9, 13b (suture and cross section, respectively) (= Coryell and Salmon, p. 15, figs. 10,11$)$; pl. 8 , figs. 5 , 6; text-fig. 10 (suture) (= Coryell and Salmon, p. 17, figs. 12, 13).

1983. Jeletzkytes cf. crassus (Coryell and Salmon, 1934). Riccardi, p. 20, pl. 7, figs. 3-5; pl. 8, figs. 1-4; pl. 22, figs. 2-4 (= Whiteaves, 1885 , p. 52 , pl. 8 , fig. 2); text-figs. $11,12,13 \mathrm{c}$ (two sutures and cross section, respectively).

1997. Jeletzkytes crassus (Coryell and Salmon, 1934). Larson et al., p. 79, 80, unnumbered figs.

2016. Jeletzkytes crassus (Coryell and Salmon, 1934). Klein, p. 137.

Microconch Synonomy

1876. Scaphites nodosus var. quadrangularis. Meek, p. 428 (pars), pl. 25, fig. 4 only; non fig. 2a-c (= Hoploscaphites brevis microconch); non fig. 3a-c (= Hoploscaphites plenus microconch).

1977. Hoploscaphties nodosus quadrangularis (Meek and Hayden). Kauffman, pl. 32, fig. 8 (= Meek. 1876, pl. 25, fig. 4).

1983. Jeletzkytes cf. brevis (Meek) ô. Riccardi, p. 25, pl. 10, figs. 1, 2 (= Meek. 1876, pl. 25, fig. 4).

1997. Jeletzkytes crassus (Coryell and Salmon, 1934). Larson et al., p. 79, 80, unnumbered figs.

1997. Jeletzkytes "quadrangularis" (Meek and Hayden, 1860). Larson et al., p. 78, unnumbered fig. (= Meek. 1876, pl. 25, fig. 4).

2010. Hoploscaphites plenus (Meek, 1876), microconch. Landman, p. 64, fig. 6A-C (= Meek, 1876, pl. 25, fig. 4).
EMEnded Diagnosis: Macroconchs medium to large in size, globose; whorl cross section of shaft depressed reniform with well-rounded flanks and broadly rounded venter; width of venter approximately 90\% whorl height; small, deep umbilicus; prominent umbilical bulge; apertural angle averaging $60^{\circ}$; long, fine, straight, closely spaced ribs on adoral part of phragmocone, with little branching or intercalation, and moderately strong adoral projection on venter; long, fine, weakly concave, moderately widely spaced ribs on shaft, with moderately strong adoral projection on venter; umbilicolateral tubercles absent or small and closely spaced on phragmocone, becoming slightly larger and more widely spaced on body chamber; ventrolateral tubercles small and closely spaced on phragmocone at $7 / 8$ whorl height, becoming slightly larger and more widely spaced on body chamber, usually persisting to aperture. Microconchs medium to large in size, robust, and more loosely uncoiled than macroconchs; umbilical wall of shaft broad and outwardly sloping; pattern of ornament similar to that of macroconchs, with relatively more prominent umbilicolateral tubercles. Suture deeply incised with broad-stemmed asymmetircally bifid first lateral saddle.

Types: The holotype is AMNH 95774 (= formerly AMNH 24234) (fig. 13) from approximately 100 feet $(30.3 \mathrm{~m})$ below the top of the Pierre Shale, a little west of the center of T. 14 N., R. 55 E., near Glendive, Dawson County, Montana (Coryell and Salmon, 1934: 15, figs. 10, 11). It was refigured by Riccardi (1983: pl. 9, figs. 3, 4) and is a steinkern with shell material preserved on the adoral part of the phragmocone. Riccardi (1983) pointed out that the specimen of Acanthoscaphites duplico-nodosus of Coryell and Salmon (1934: 17, figs. 12,13) is a fragment of a phragmocone of a macroconch of $H$. crassus. We concur and, as first revising authors, select crassus as the name bearer of this species. Whiteaves (1885) described two specimens, both of which are phragmocones, from the Bearpaw Shale of Saskatchewan, as 
A

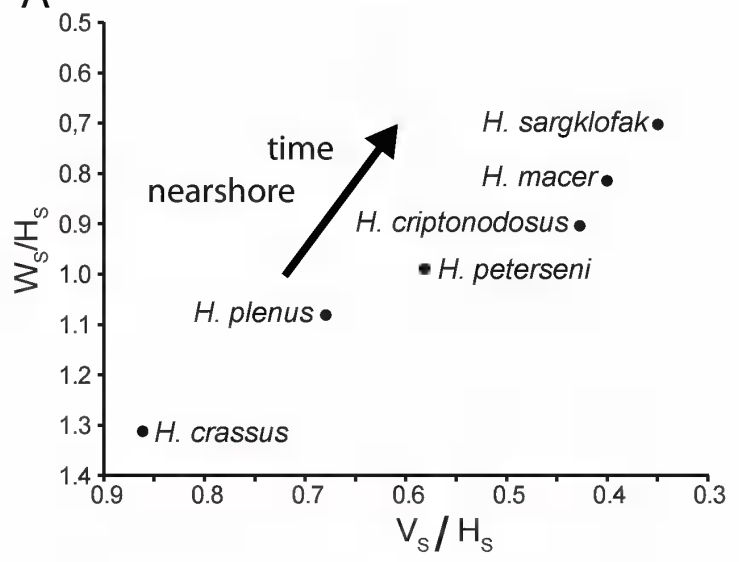

$\mathrm{B}$

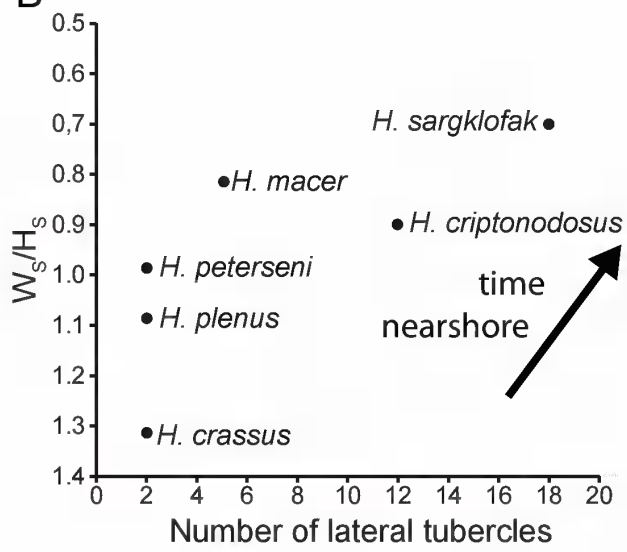

Source

Lateral tubercles (number)

\begin{tabular}{|c|c|c|c|c|c|c|c|c|c|}
\hline Species & Zone & Ws/Hs & & & Vs/Hs & & & Source & \\
\hline & & Mean & SD & $\mathrm{n}$ & Mean & SD & $\mathrm{n}$ & & \\
\hline H. crassus & $\mathrm{Be}-\mathrm{IBb}$ & 1.31 & 0.12 & 32 & 0.87 & 0.10 & 28 & table 1 & 2 \\
\hline H. criptonodosus & $\mathrm{uBb}-\mathrm{Bg}$ & 0.90 & 0.07 & 39 & 0.43 & 0.07 & 39 & Landman et al., 2019: table 3 & 12 \\
\hline H. macer & $\begin{array}{l}\mathrm{uBb}- \\
\mathrm{lBg}\end{array}$ & 0.81 & 0.06 & 34 & 0.40 & 0.05 & 34 & Landman et al., 2019: table 1 & \\
\hline H. peterseni & $\mathrm{Be}-\mathrm{IBb}$ & 0.99 & 0.09 & 26 & 0.68 & 0.09 & 32 & table 5 & \\
\hline H. plenus & $\mathrm{Be}-\mathrm{IBb}$ & 1.09 & 0.08 & 32 & 0.58 & 0.08 & 23 & table 4 & ? \\
\hline H. sargklofak & $\mathrm{Bg}$ & 0.70 & 0.06 & 33 & 0.35 & 0.06 & 27 & Landman et al., 2015: table 1 & 18 \\
\hline
\end{tabular}

FIGURE 11. Comparison of the degree of whorl compression and tuberculation in macroconchs of six species of Hoploscaphites from the Baculites eliasi-B. grandis zones of the Pierre Shale (see table below for source of measurements). A. Plot of the average values of $\mathrm{W}_{S} / \mathrm{Hs}$ vs $\mathrm{V}_{S} / \mathrm{H}_{\mathrm{S}}$ reveals a trend toward more compressed shells in geologically younger species (toward upper right). B. Plot of the average values of $\mathrm{W}_{\mathrm{S}} / \mathrm{Hs}$ versus the maximum number of lateral tubercles on the adult shell also reveals a trend toward increased tuberculation in geologically younger species (toward upper right). Both trends may reflect a shift to more nearshore environments. Abbreviations: Be, Baculites eliasi Zone; Bg, B. grandis Zone; $\mathbf{l B b}$, lower B. baculus Zone; $\mathbf{u B b}$, upper B. baculus Zone; $\mathbf{1 B g}$, lower B. grandis Zone.

Scaphites subglobosus. As discussed by Cobban (1987), the larger one (Whiteaves, 1885: 52, pl. 7, fig. 3; pl. 8, fig. 1) is the lectotype of Rhaeboceras subglobosum. The smaller one (Whiteaves, 1885: 52, pl. 8, fig. 2) was assigned by Elias (1933) to $H$. plenus. It is characterized by numerous ventrolateral tubercles, a globose shell shape, and a depressed reniform whorl section. Because it is only part of a phragmocone, it is impossible to identify it to the species level with complete confidence, but we tentatively assign it to $H$. crassus, in agreement with Riccardi (1983: 20).
Meek (1876: 428) illustrated three specimens of Scaphites nodosus var. quadrangularis. These specimens represent microconchs of three species. One of the paratypes (USNM 365) illustrated by Meek (1876: pl. 25, fig. 4) is a robust specimen with coarse, widely spaced ribs. We interpret it as a microconch of Hoploscaphites crassus (fig. 33). It is probably from the Pierre Shale on the Cedar Creek Anticline, east-central Montana. The holotype of S. nodosus var. quadrangularis (USNM 366) illustrated by Meek (1876: pl. 25, fig. 3a-c) is a microconch of $H$. plenus (fig. $56 \mathrm{H}-\mathrm{K}$ ), from the 


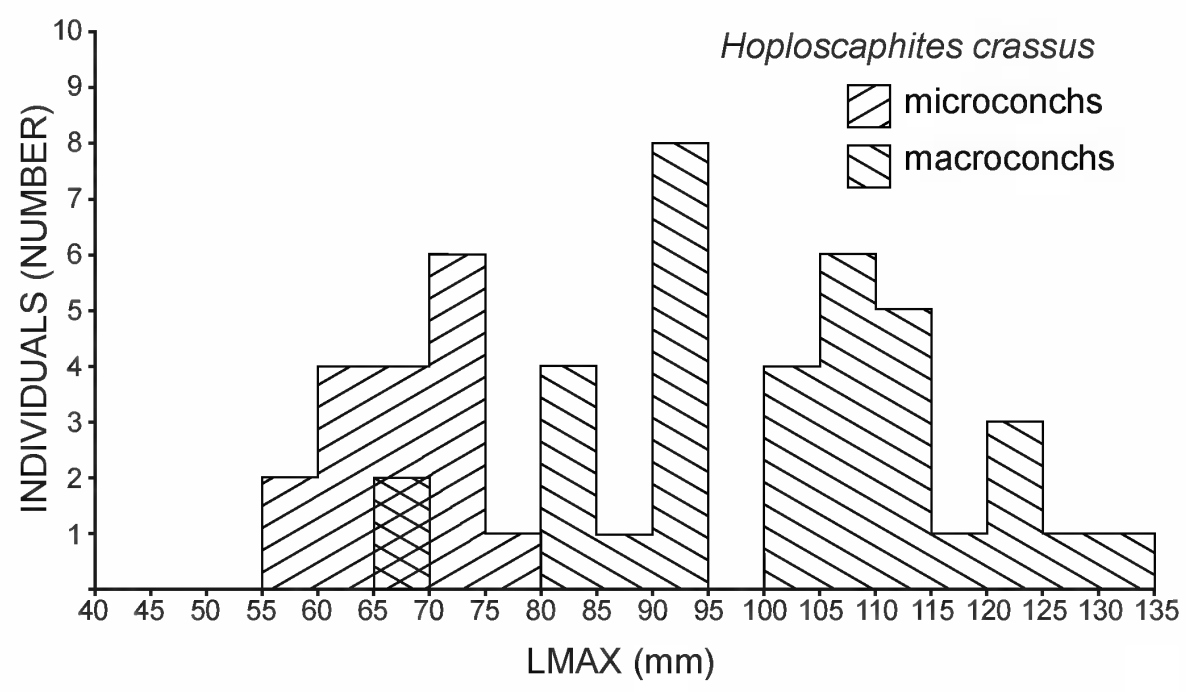

FIGURE 12. Size frequency histogram of Hoploscaphites crassus (Coryell and Salmon, 1934), based on the samples in tables 1 and 2.

same site, and is treated later in the text. The other paratype of S. nodosus var. quadrangularis (USNM 386690), illustrated by Meek (1876: pl. 25, fig. 2a-c), is a microconch of $H$. brevis (Meek, 1876), as discussed by Landman et al. (2010: 15-17, 160, 161, fig. 6D-G). It is probably from the Pierre Shale on the south fork of the Cheyenne River, South Dakota.

MATERIAL: The collection consists of 85 complete or nearly complete macroconchs and microconchs of which 32 macroconchs and 17 microconchs comprise the measured set. Those for which we have detailed information are from the upper part of the Baculites eliasi Zone and lower part of the B. baculus Zone. They are especially abundant in the scaphite concretionary layer in the lower part of the B. baculus Zone of the Pierre Shale on the Cedar Creek Anticline, Montana (Bishop, 1967, 1973).

Macroconch Description: Macroconchs are robust and medium to large in size. LMAX averages $102.5 \mathrm{~mm}$ and ranges from 67.7 to $131.0 \mathrm{~mm}$ (table 1). The ratio of the size of the largest specimen to that of the smallest is 1.86 . The holotype is on the larger end of the spectrum (LMAX $=114.2 \mathrm{~mm}$ ). The size distribution is broad with two notable gaps at 70-80 $\mathrm{mm}$ and 95-100 mm (fig. 12).
All specimens share in common a globose shape with a circular to oval outline in side view. In smaller specimens like AMNH 76341 (fig. 16), the shell is rounded in outline $\left(\mathrm{LMAX} / \mathrm{H}_{\mathrm{S}}=\right.$ 1.95), whereas in larger specimens, like the holotype (fig. 13), the shell is more oval in outline $\left(\mathrm{LMAX} / \mathrm{H}_{\mathrm{S}}=2.27\right)$. All specimens are tightly coiled. In smaller specimens like BHI 4291 (fig. 22 ), the hook is closely pressed against the phragmocone $\left(\mathrm{LMAX} / \mathrm{H}_{\mathrm{P} 2}=2.62\right)$, whereas in larger specimens, like the holotype (fig. 13), a small gap appears at this point (LMAX/ $\mathrm{H}_{\mathrm{P} 2}=$ 2.80).

The phragmocone occupies approximately $1 / 2$ whorl and usually terminates just below the line of maximum length. The apertural angle averages $58.1^{\circ}$ and ranges from 40 to $71^{\circ}$. The apertural lip is flexuous with a deep constriction and accompanying varix. The dorsal margin of the aperture is bordered by an elongate, broadly rounded projection, as shown in AMNH 77604 (fig. 24).

The umbilicus is small and deep. The umbilical diameter averages $6.0 \mathrm{~mm}$ and ranges from 3.8 to $8.6 \mathrm{~mm}$ (table 1). UD/LMAX averages 0.06 and ranges from 0.04 to 0.07 . The umbilicus is partially occluded by an umbilical bulge on the umbilical shoulder of the shaft. Due to the presence of the umbilical bulge, the outline of 

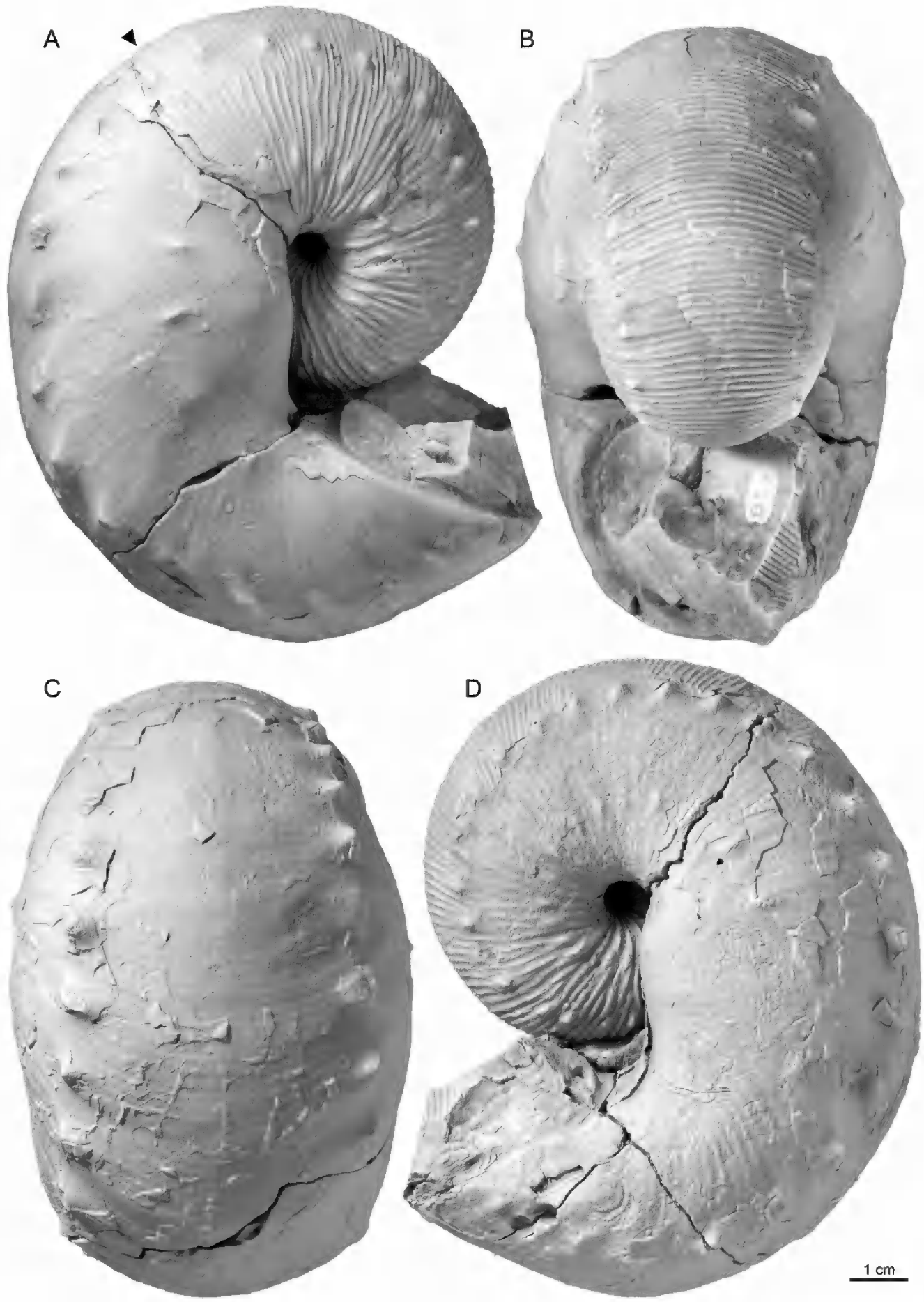

FIGURE 13. Hoploscaphites crassus (Coryell and Salmon, 1934), macroconch. A-D. AMNH 95774 (= formerly AMNH 24234), holotype, Baculites baculus Zone, Pierre Shale, Cedar Creek Anticline, east-central Montana. A, Right lateral; B, apertural; C, ventral; D, left lateral. Arrow indicates the base of the body chamber. 

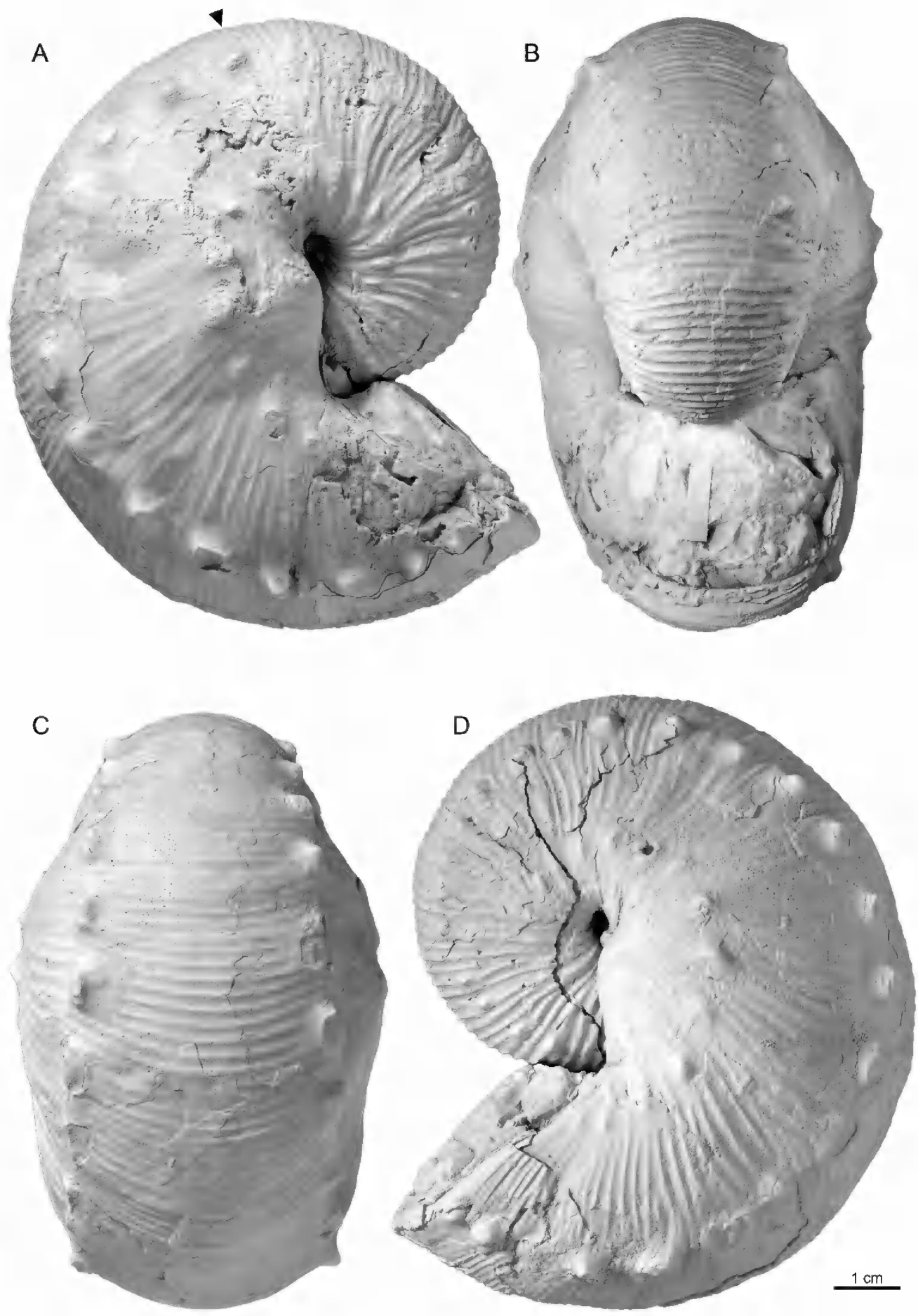

FIGURE 14. Hoploscaphites crassus (Coryell and Salmon, 1934), macroconch, A-D. AMNH 72741, transitional to H. peterseni, AMNH loc. 3921, lower Baculites baculus Zone, Pierre Shale, Cedar Creek Anticline, east-central Montana. A, Right lateral; B, apertural; C, ventral; D, left lateral. Arrow indicates the base of the body chamber. 


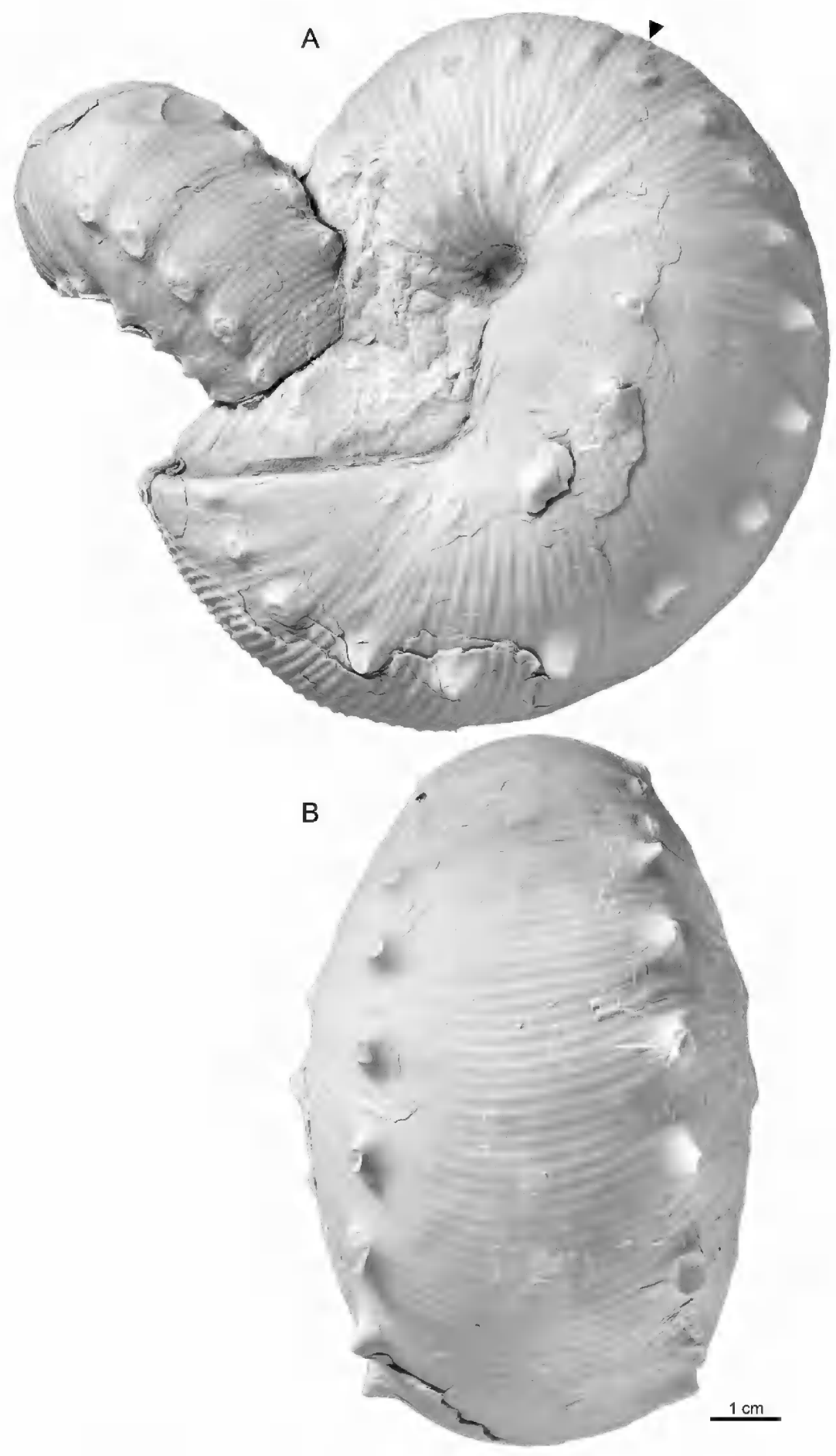

FIGURE 15. Hoploscaphites crassus (Coryell and Salmon, 1934), macroconch. A, B. AMNH 134699, macroconch with microconch attached, AMNH loc. 3921, lower Baculites baculus Zone, Pierre Shale, Cedar Creek Anticline, east-central Montana. A, Left lateral; B, ventral. Arrow indicates the base of the body chamber. 


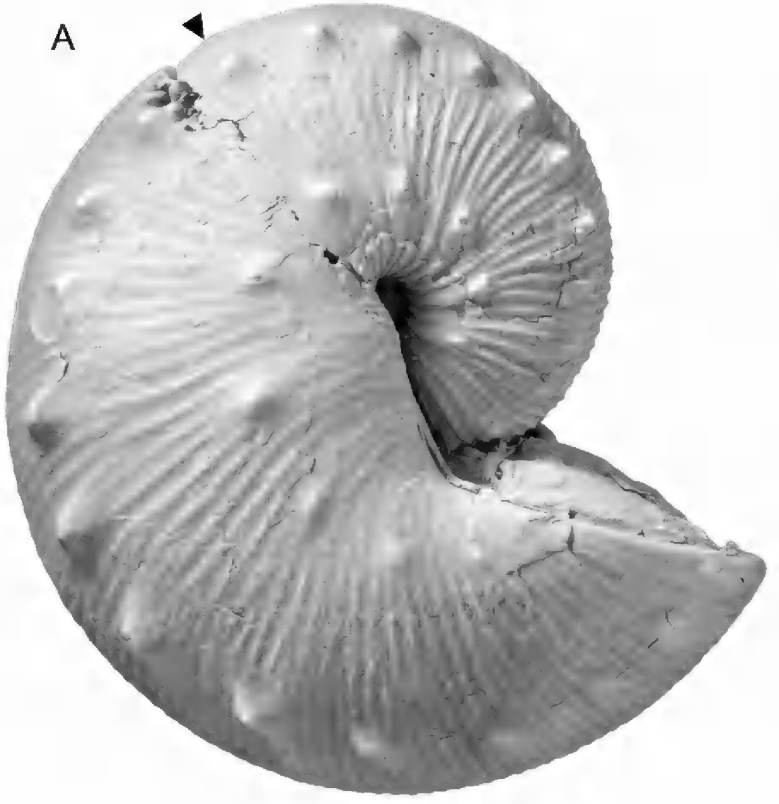

B
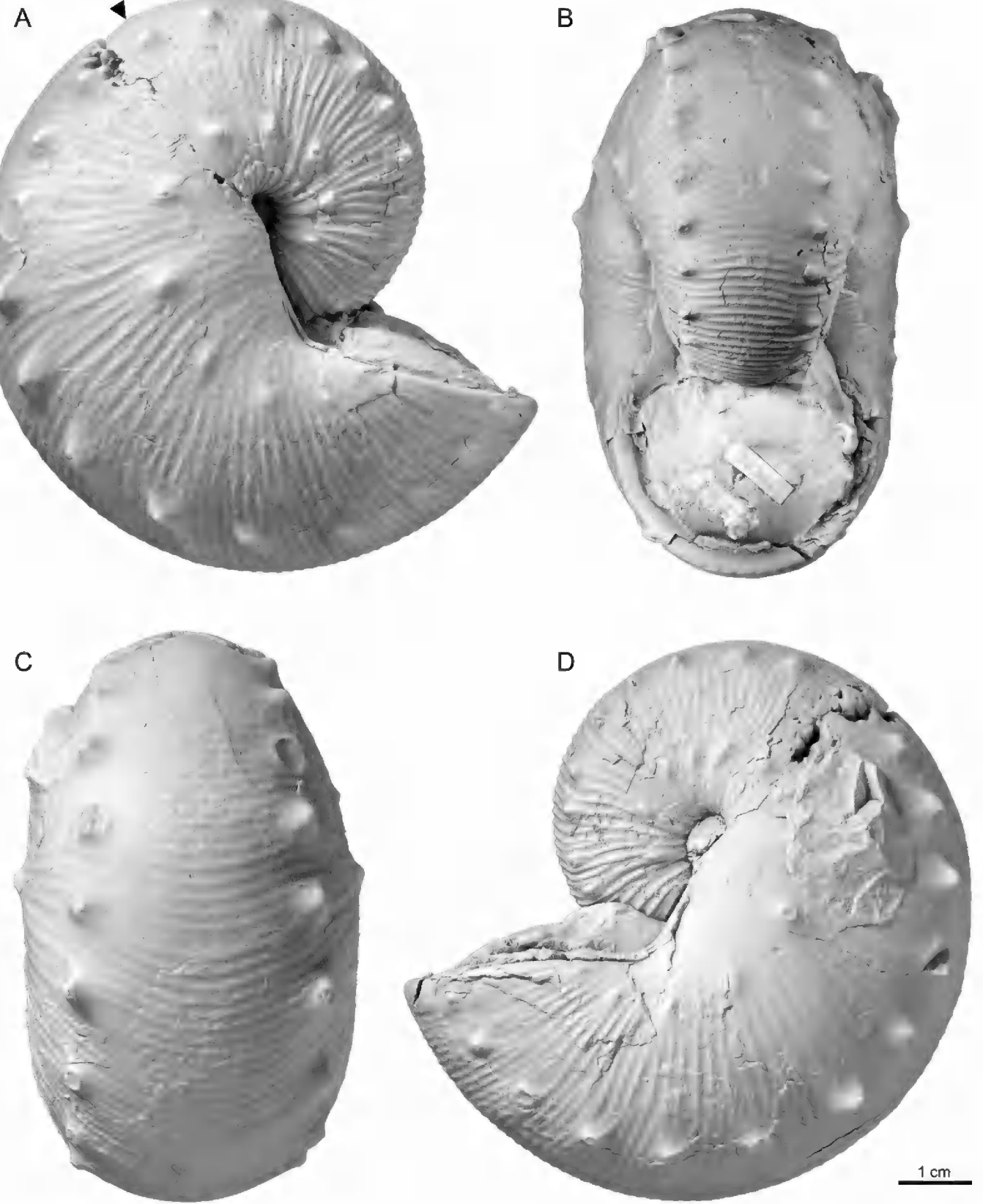

FIGURE 16. Hoploscaphites crassus (Coryell and Salmon, 1934), macroconch. A-D. AMNH 76341, small specimen, AMNH loc. 3921, Baculites baculus or lower B. grandis zones, Pierre Shale, Cedar Creek Anticline, east-central Montana. A, Right lateral; B, apertural; C, ventral; D, left lateral. Arrow indicates the base of the body chamber. 


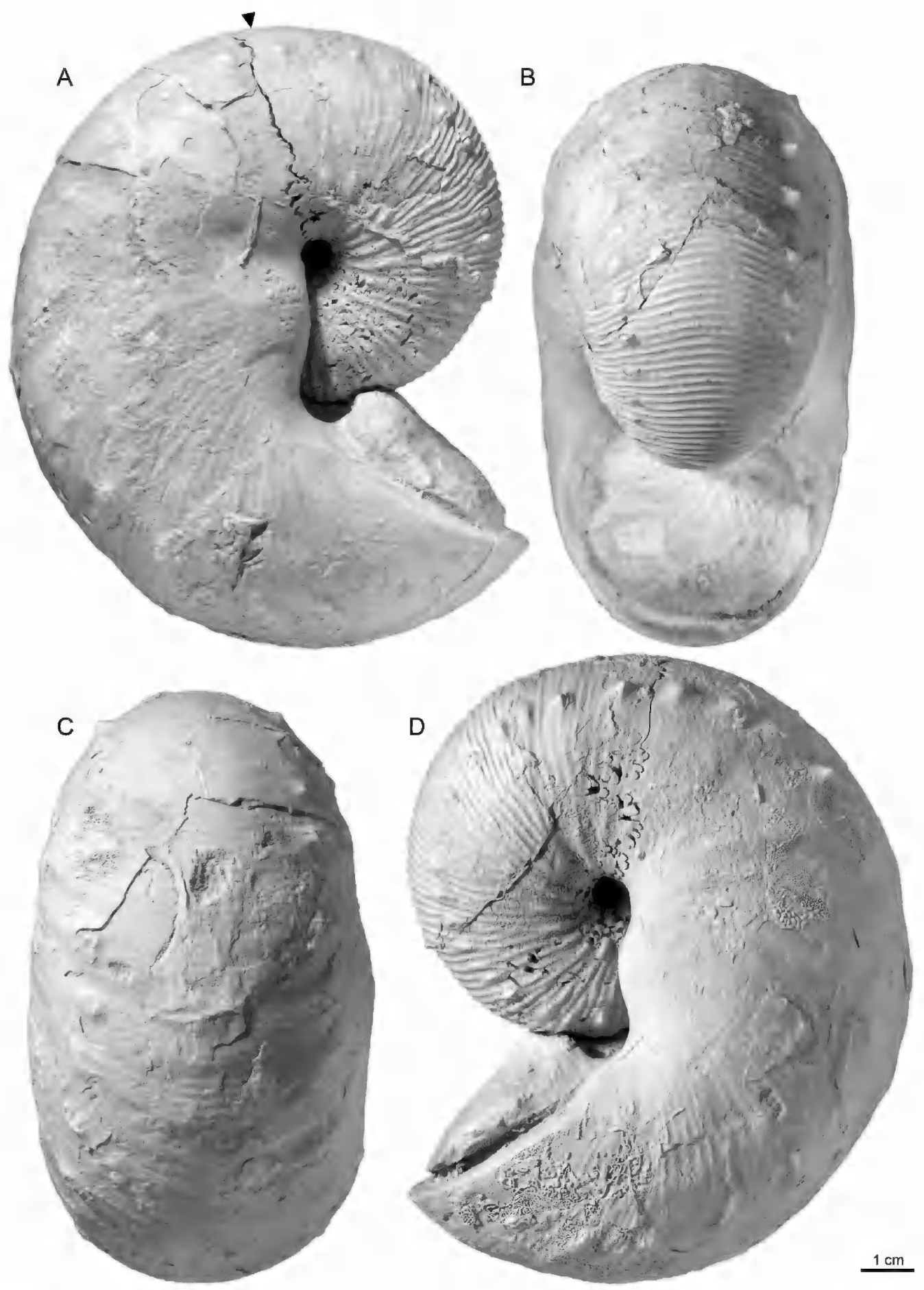

FIGURE 17. Hoploscaphites crassus (Coryell and Salmon, 1934), macroconch. A-D. YPM 35609, YPM loc. A4778, lower Baculites baculus Zone, Pierre Shale, Niobrara County, Wyoming. A, Right lateral; B, apertural; C, ventral; D, left lateral. Arrow indicates the base of the body chamber. 


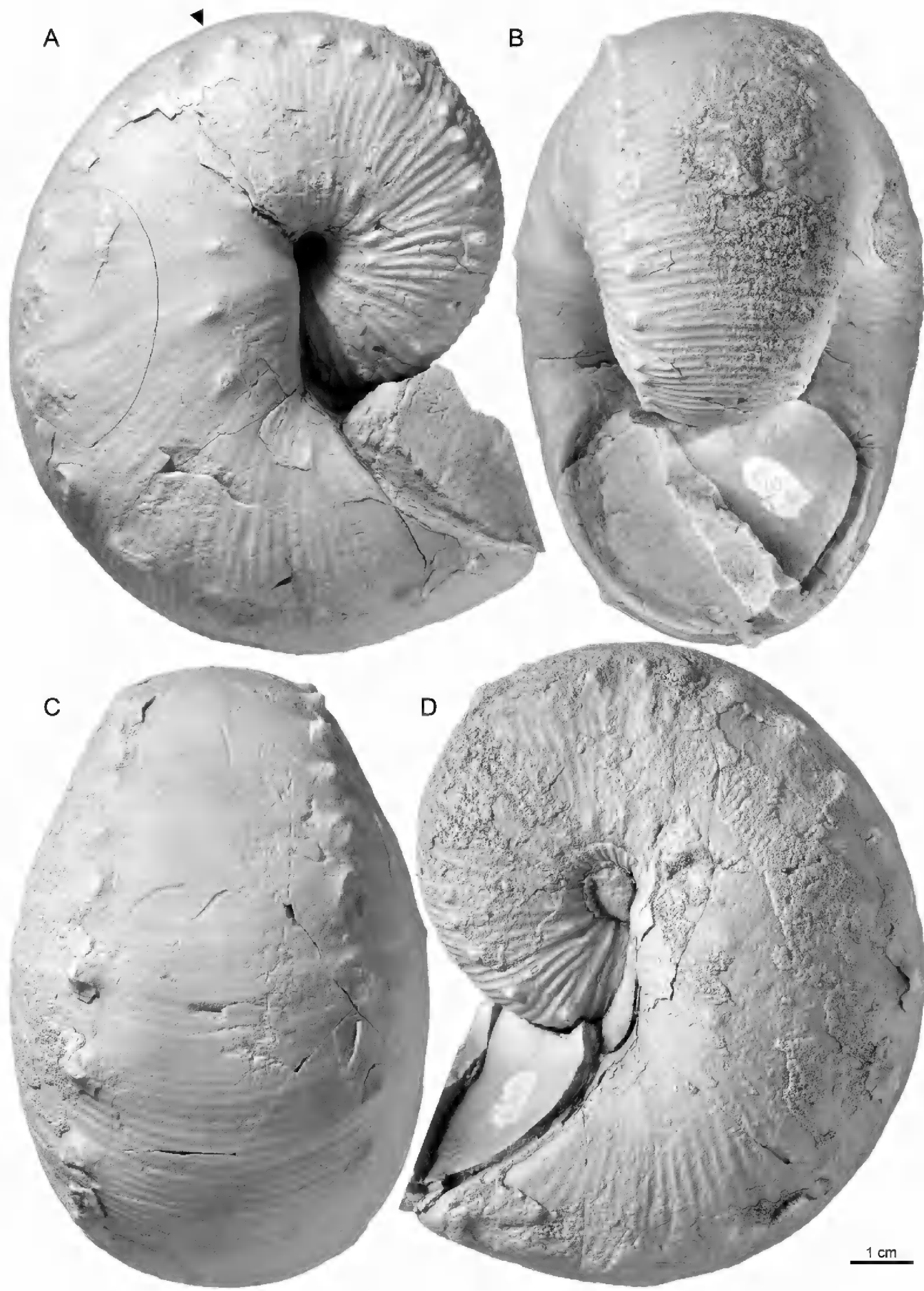

FIGURE 18. Hoploscaphites crassus (Coryell and Salmon, 1934), macroconch. A-D. YPM 35608, YPM loc. A4778, lower Baculites baculus Zone, Pierre Shale, Niobrara County, Wyoming. A, Right lateral; B, apertural; C, ventral; D, left lateral. Arrow indicates the base of the body chamber. 


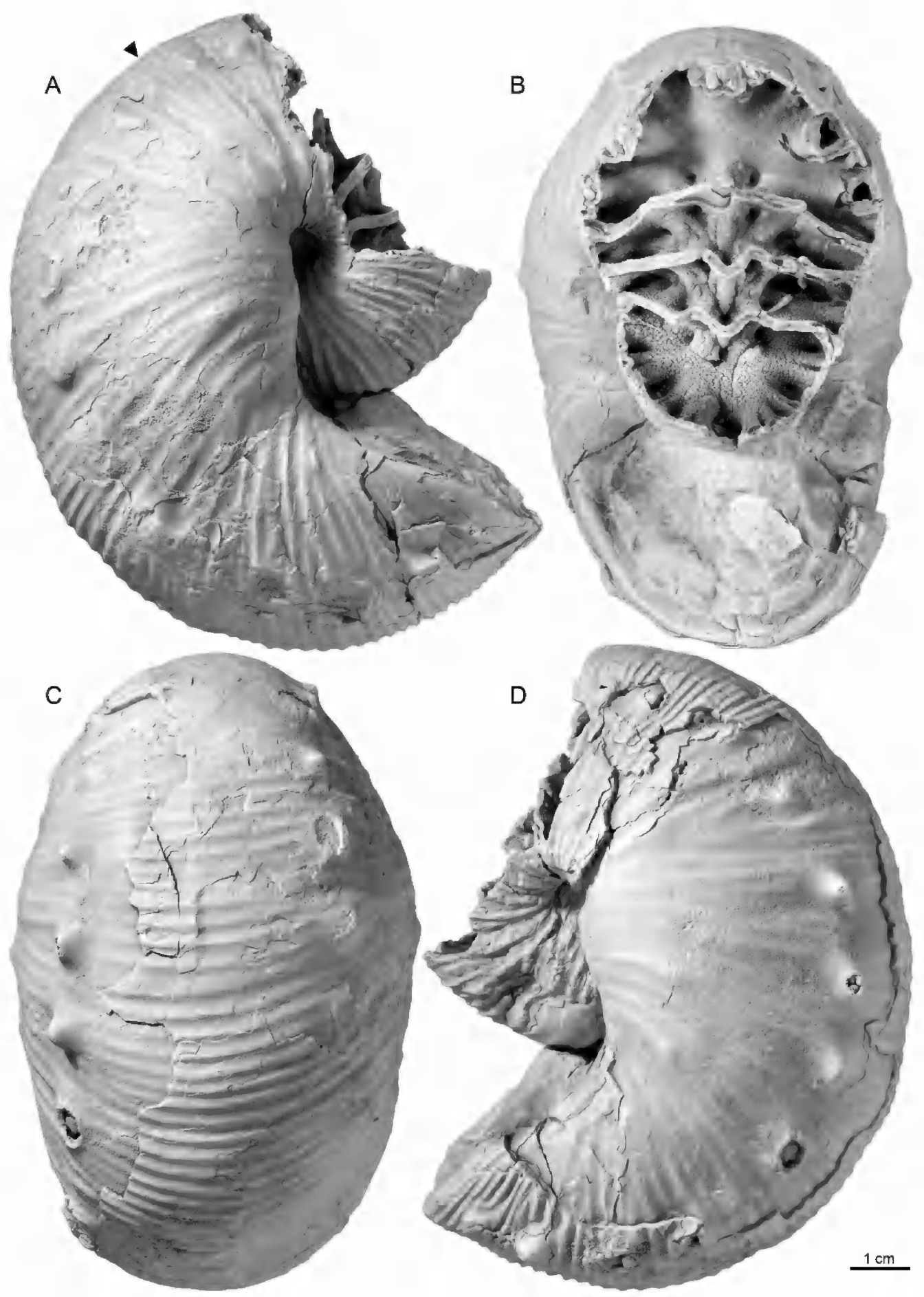

FIGURE 19. Hoploscaphites crassus (Coryell and Salmon, 1934), macroconch. A-D. SDSM 149986, coarsely ornamented specimen, Baculites baculus Zone, Pierre Shale, Cedar Creek Anticline, east-central Montana. A, Right lateral; B, apertural; C, ventral; D, left lateral. Arrow indicates the base of the body chamber. 

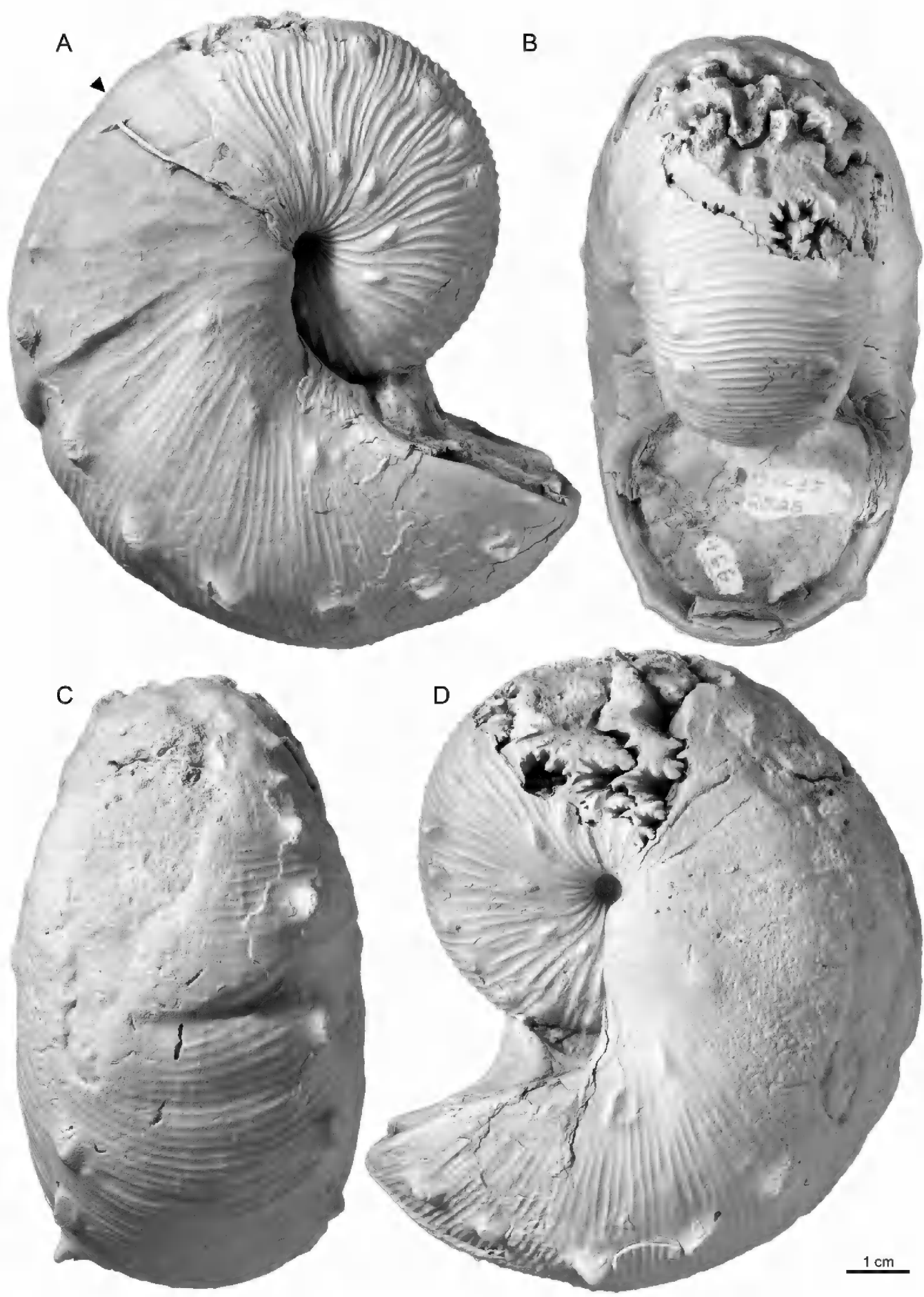

FIGURE 20. Hoploscaphites crassus (Coryell and Salmon, 1934), macroconch. A-D. SDSM 149985, nonlethal injury on the venter of the shaft, Baculites baculus Zone, Pierre Shale, Cedar Creek Anticline, east-central Montana. A, Right lateral; B, apertural; C, ventral; D, left lateral. Arrow indicates the base of the body chamber. 

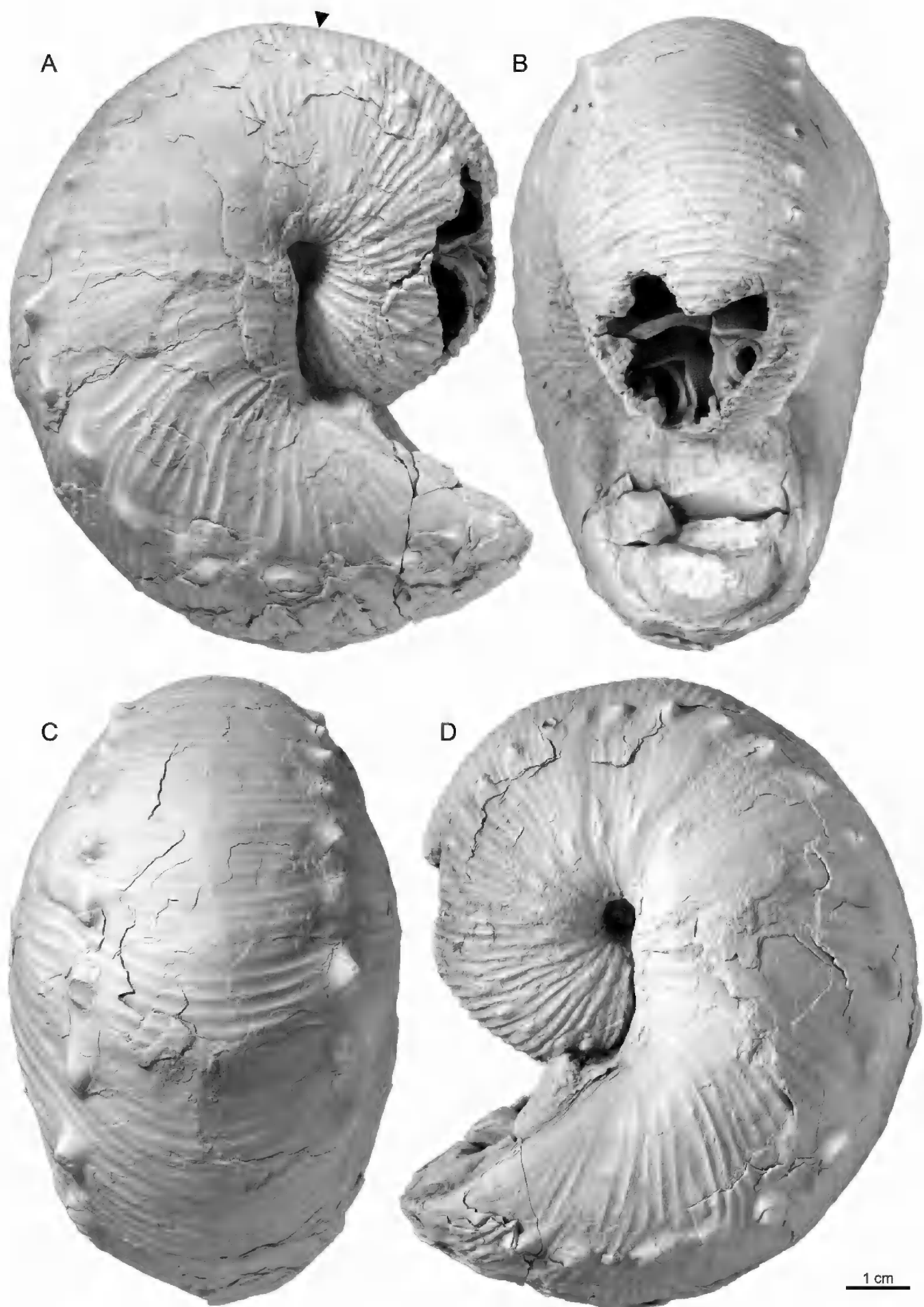

FIGURE 21. Hoploscaphites crassus (Coryell and Salmon, 1934), macroconch. A-D. SDSM 149983, Baculites baculus Zone, Pierre Shale, Cedar Creek Anticline, east-central Montana. A, Right lateral; B, apertural; C, ventral; $\mathbf{D}$, left lateral. Arrow indicates the base of the body chamber. 
A

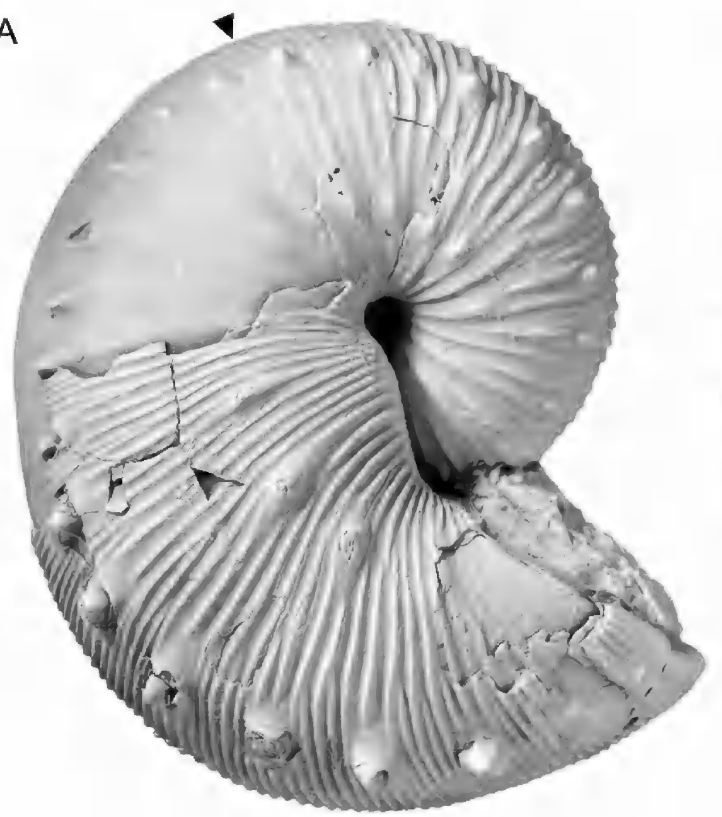

B
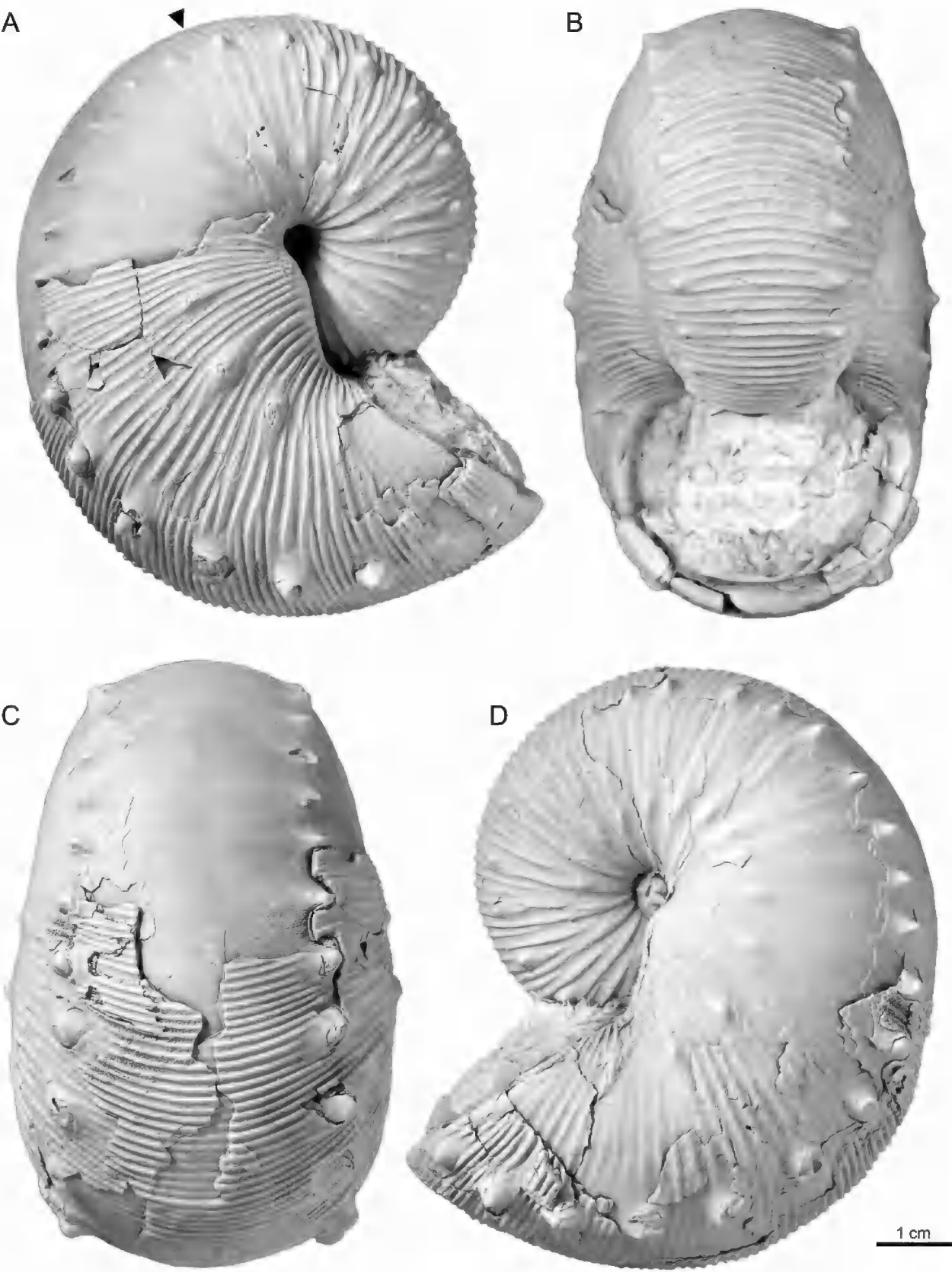

FIGURE 22. Hoploscaphites crassus (Coryell and Salmon, 1934), macroconch. A-D. BHI 4291, small specimen, Baculites baculus Zone, Pierre Shale, Cedar Creek Anticline, east-central Montana. A, Right lateral; B, apertural; C, ventral; D, left lateral. Arrow indicates the base of the body chamber. 

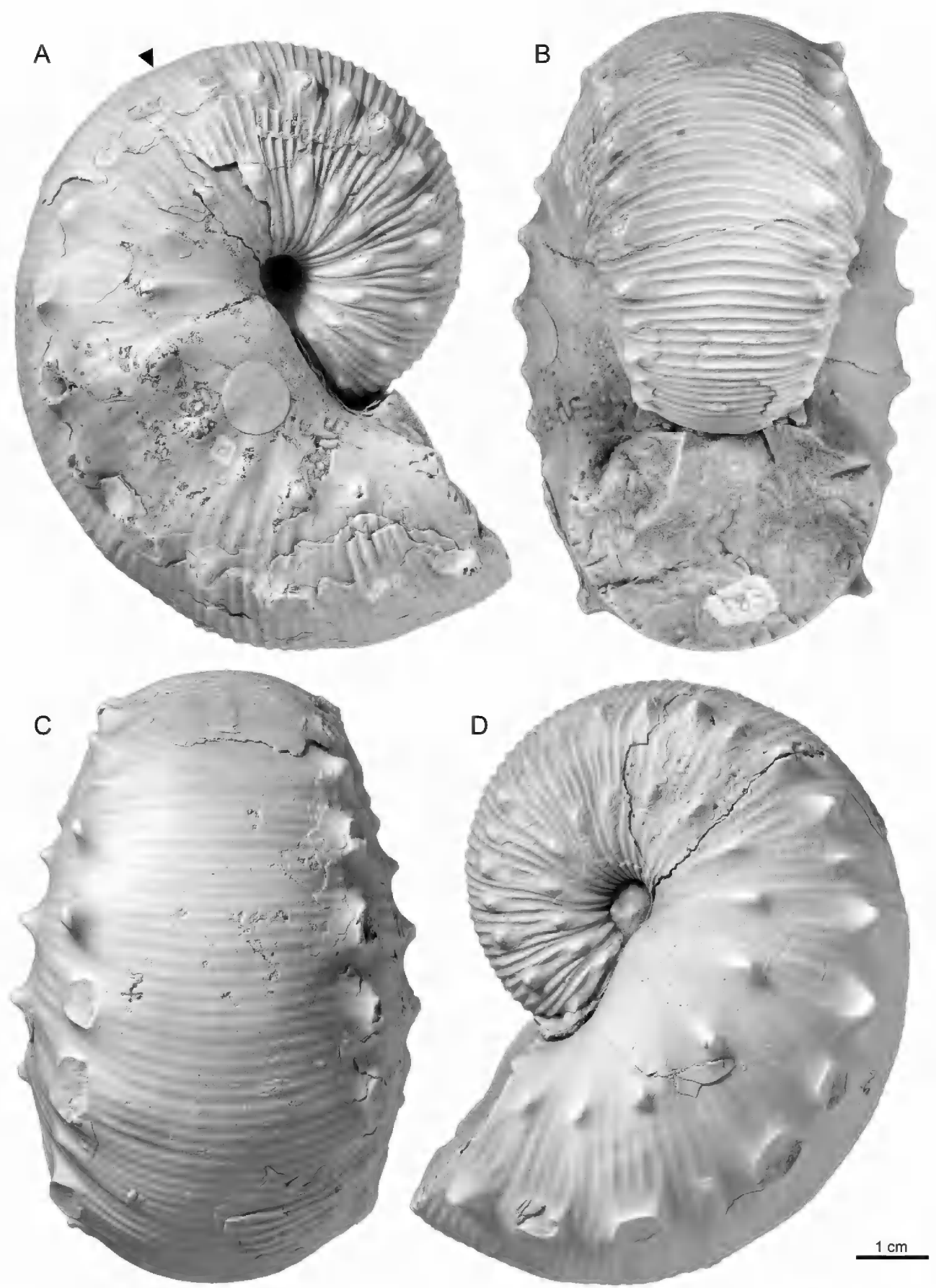

FIGURE 23. Hoploscaphites crassus (Coryell and Salmon, 1934), macroconch. A-D. USNM 723203, small specimen with globular whorl section but widely spaced ventrolateral tubercles, USGS loc. 12745, lower Baculites baculus Zone, Pierre Shale, Cedar Creek Anticline, east-central Montana. A, Right lateral; B, apertural; C, ventral; D, left lateral. Arrow indicates the base of the body chamber. 

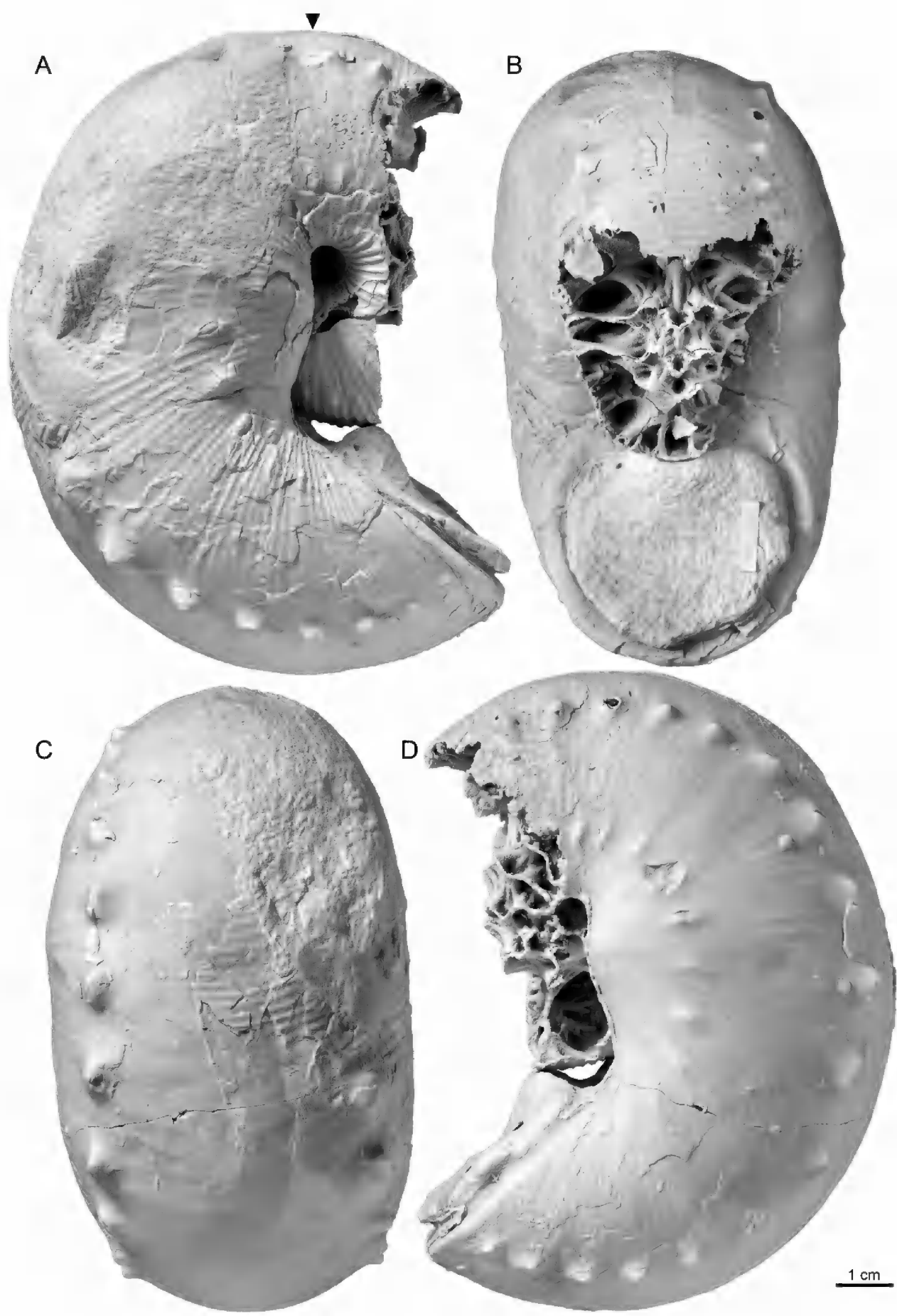

FIGURE 24. Hoploscaphites crassus (Coryell and Salmon, 1934), macroconch. A-D. AMNH 77604, with large piece of shell missing from the adapical part of the body chamber (smooth area) indicating a lethal injury, AMNH loc. 3246, lower Baculites baculus Zone, Pierre Shale, Wibaux (= Mingusville), Montana. A, Right lateral; B, apertural; C, ventral; D, left lateral. Arrow indicates the base of the body chamber. 


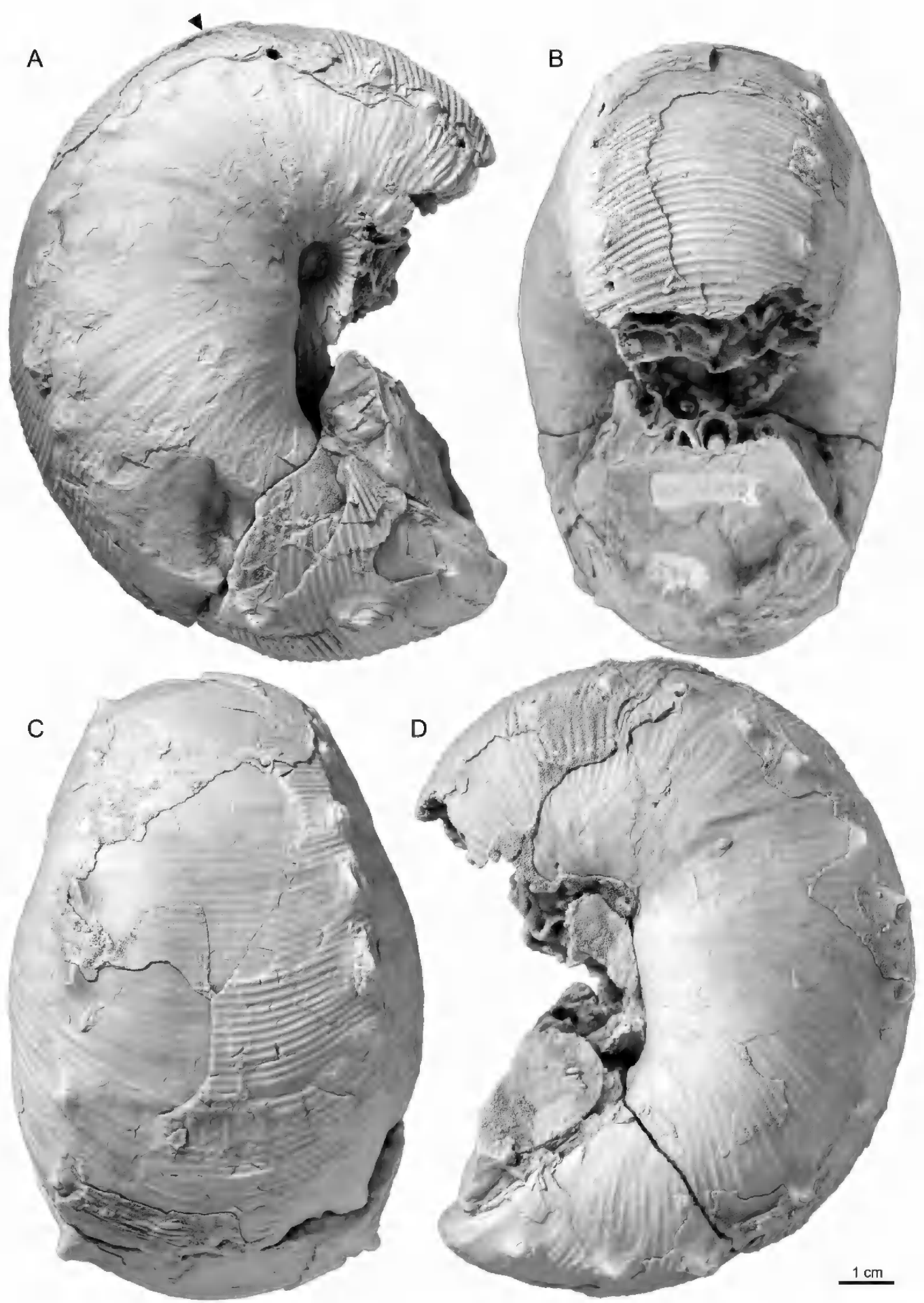

FIGURE 25. Hoploscaphites crassus (Coryell and Salmon, 1934), macroconch. A-D. BHI 4292, Baculites baculus Zone, Pierre Shale, Cedar Creek Anticline, east-central Montana. A, Right lateral; B, apertural; C, ventral; D, left lateral. Arrow indicates the base of the body chamber. 

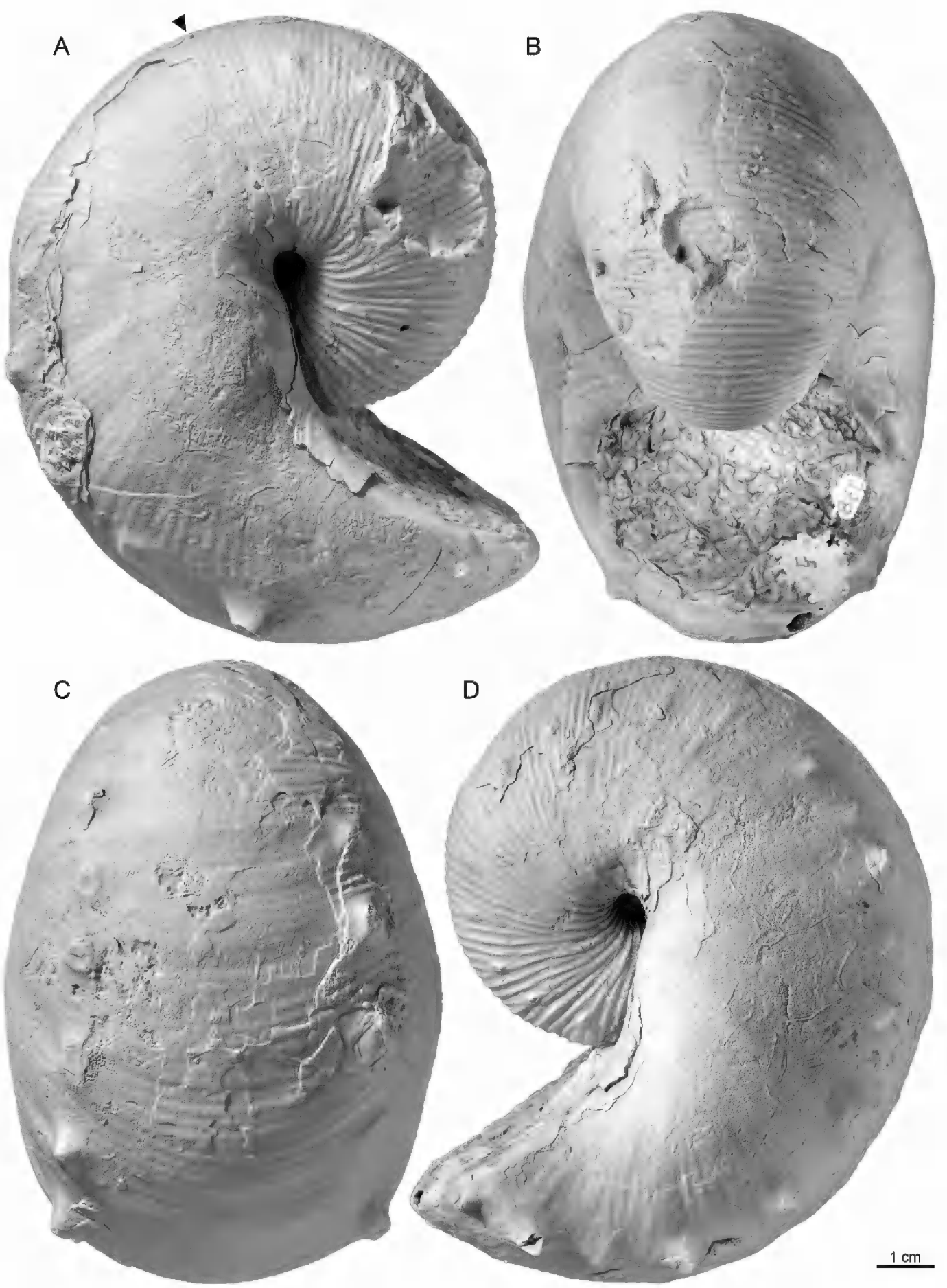

FIGURE 26. Hoploscaphites crassus (Coryell and Salmon, 1934), macroconch. A-D. AMNH 135326, robust specimen with unusually widely spaced ventrolateral tubercles, AMNH loc. 3921, lower Baculites baculus Zone, Pierre Shale, Cedar Creek Anticline, east-central Montana. A, Right lateral; B, apertural; C, ventral; D, left lateral. Arrow indicates the base of the body chamber. 


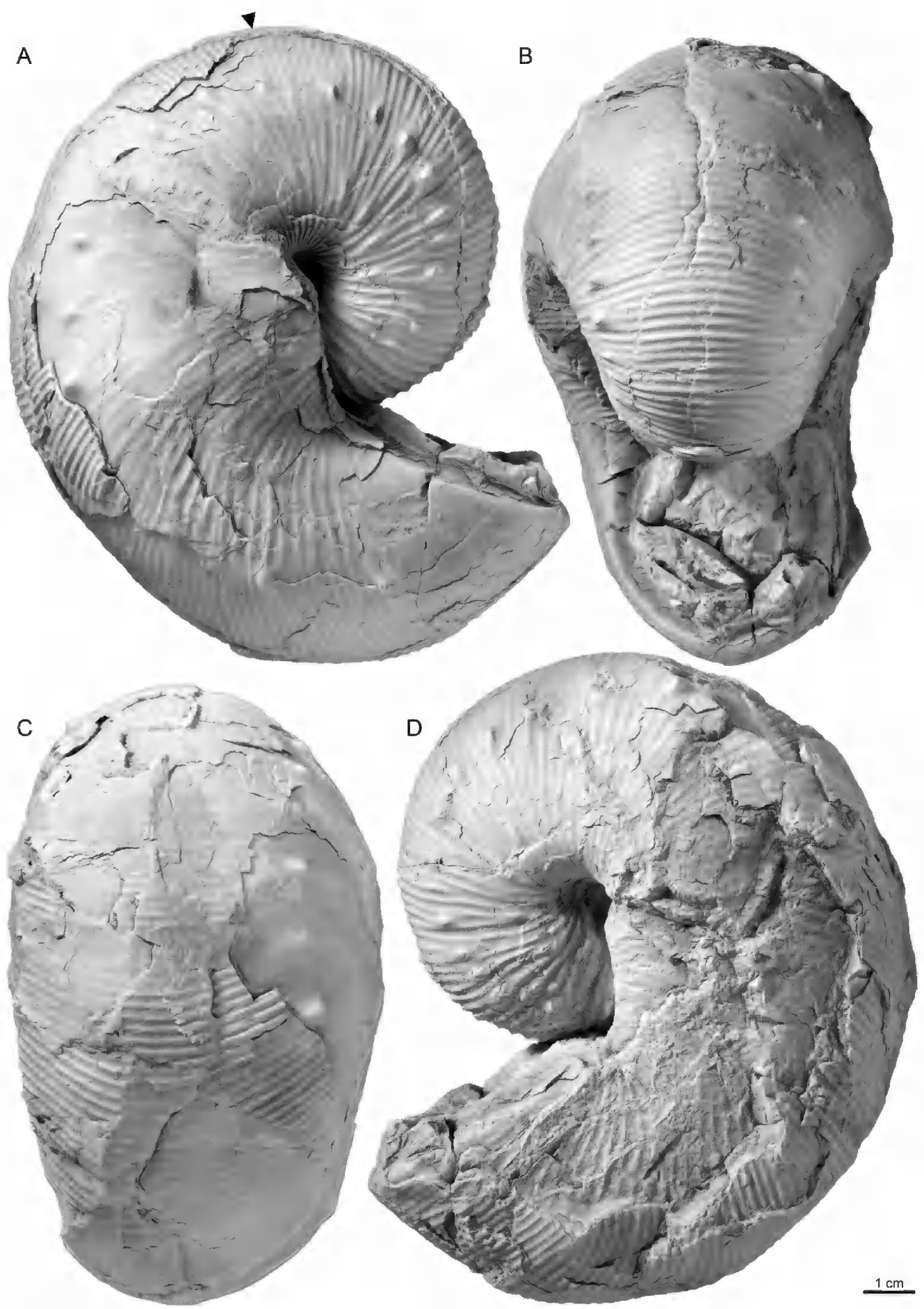

FIGURE 27. Hoploscaphites crassus (Coryell and Salmon, 1934), macroconch. A-D. SDSM 149987, somewhat crushed, Baculites baculus Zone, Pierre Shale, Cedar Creek Anticline, east-central Montana. A, Right lateral; B, apertural; C, ventral; D, left lateral. Arrow indicates the base of the body chamber. 

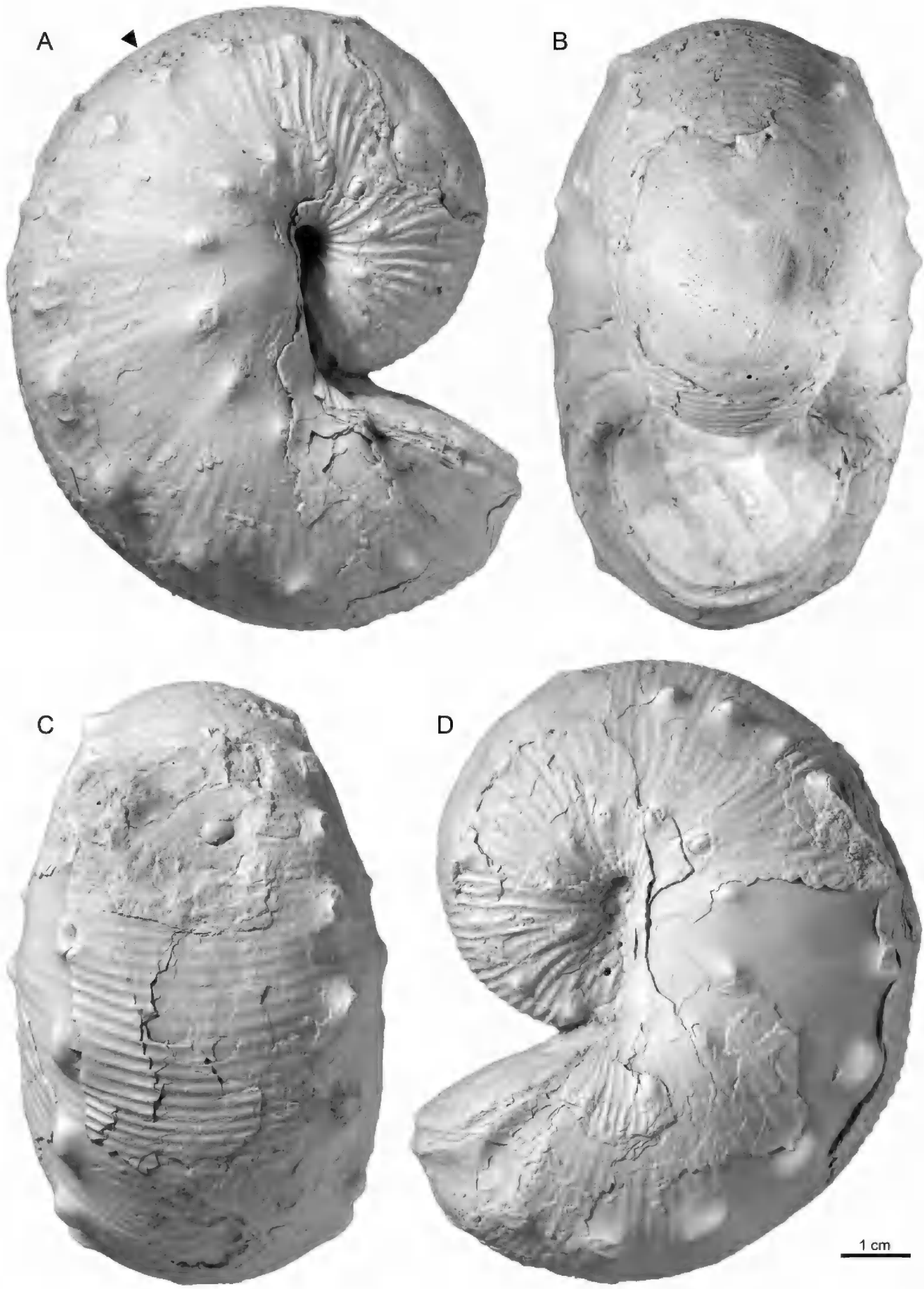

FIGURE 28. Hoploscaphites crassus (Coryell and Salmon, 1934), macroconch. A-D. BHI 4301, with pinched-in area near the aperture, Baculites baculus Zone, Pierre Shale, Cedar Creek Anticline, east-central Montana. A, Right lateral; B, apertural; C, ventral; D, left lateral. Arrow indicates the base of the body chamber. 

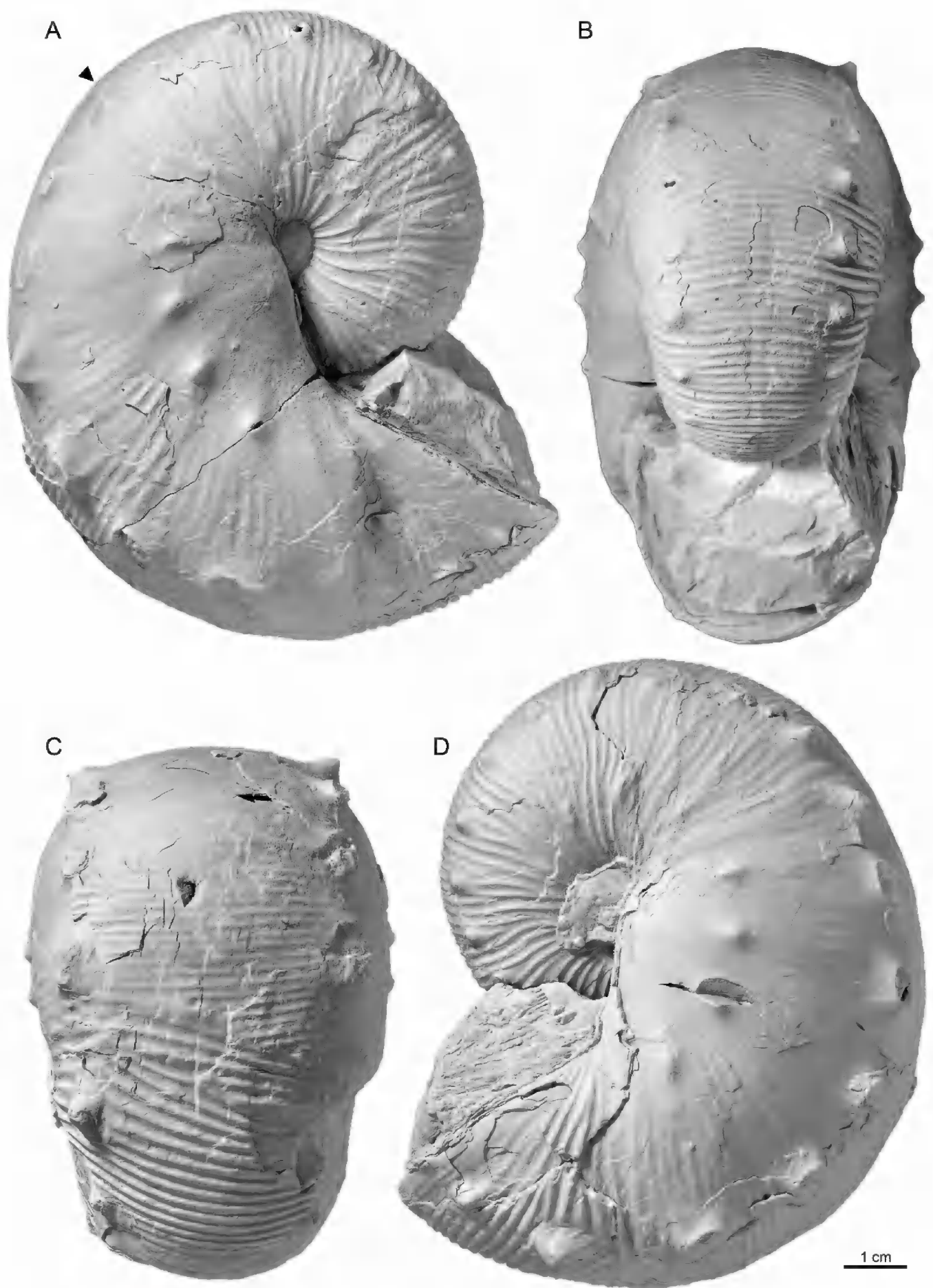

FIGURE 29. Hoploscaphites crassus (Coryell and Salmon, 1934), macroconch. A-D. FMNH UC 3653A, unknown locality, but probably Baculites baculus Zone, Pierre Shale, Cedar Creek Anticline, east-central Montana. A, Right lateral; B, apertural; C, hook; D, left lateral. Note the disruption in the ribbing on the venter due to a nonlethal injury. Arrow indicates the base of the body chamber. 


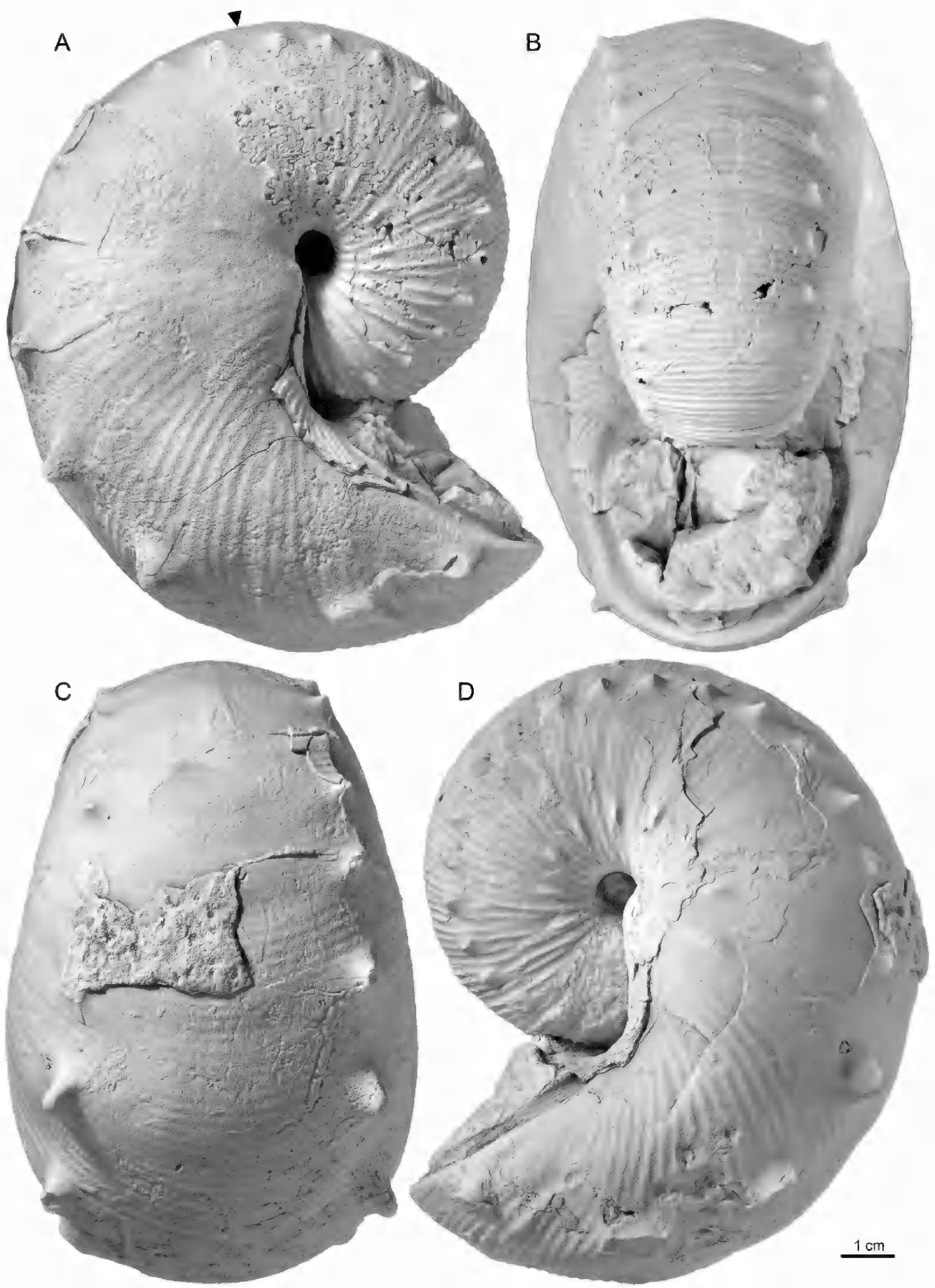

FIGURE 30. Hoploscaphites crassus (Coryell and Salmon, 1934), macroconch, with widely spaced ventrolateral tubercles. A-D. ANSP IP 81678, transitional to H. plenus (Meek and Hayden, 1860), unknown locality, but probably Baculites baculus Zone, Pierre Shale, Cedar Creek Anticline, east-central Montana. A, Right lateral; B, apertural; C, ventral; D, left lateral. Arrow indicates the base of the body chamber. 


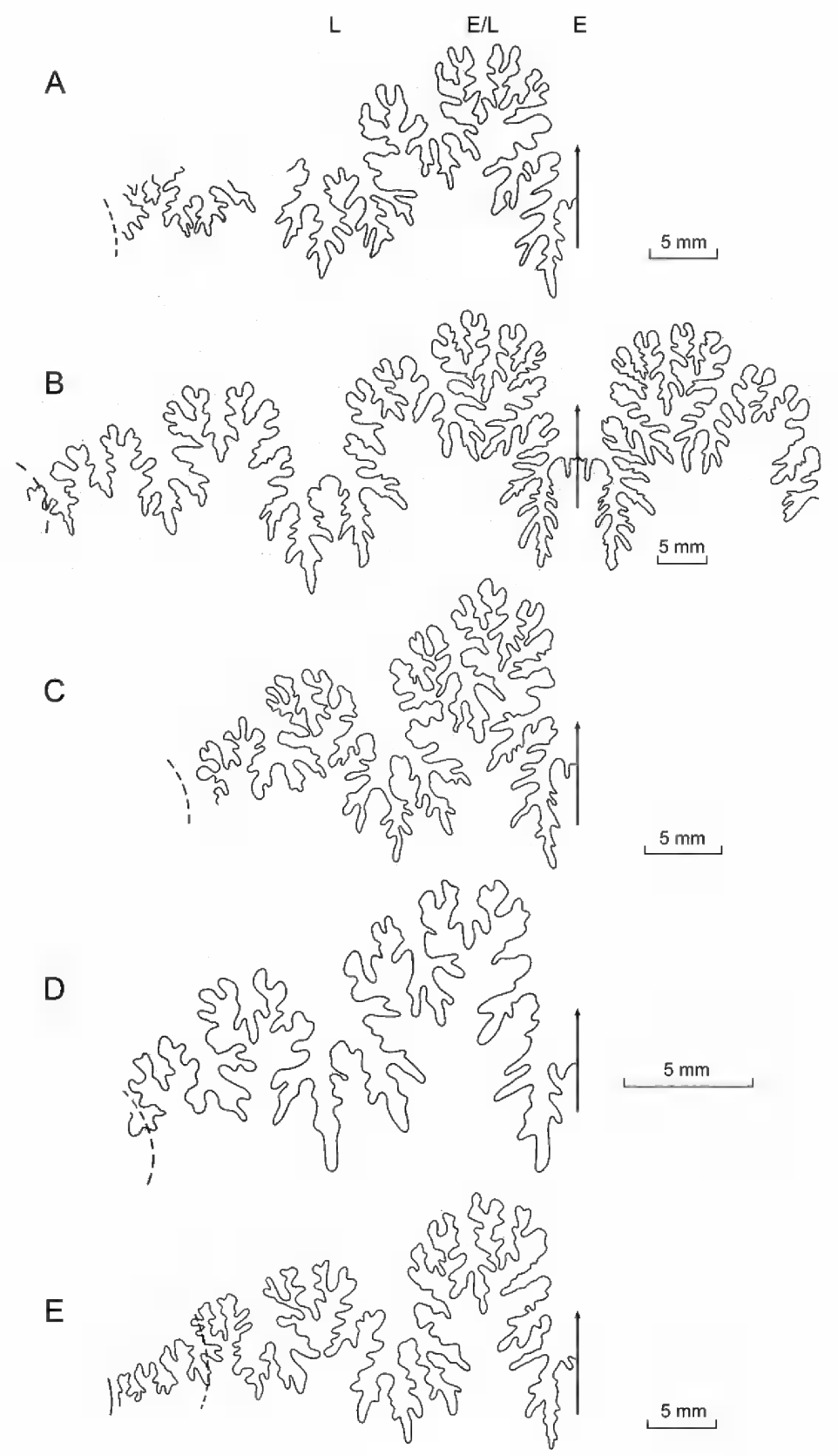

FIGURE 31. Sutures of Hoploscaphites crassus (Coryell and Salmon, 1934), macroconchs. A. AMNH 95774 (= formerly AMNH 24234), holotype, $\mathrm{W}=43.6 \mathrm{~mm}, \mathrm{H}=34 \mathrm{~mm}$, Baculites baculus Zone, Pierre Shale, Cedar Creek Anticline, Montana (from Riccardi, 1983, text-fig. 9). B. ANSP IP 81678, third from last suture, $\mathrm{H}=31.8 \mathrm{~mm}$, locality unknown, but probably Baculites baculus Zone, Pierre Shale, Cedar Creek Anticline, Montana. C. AMNH 24235, holotype, Acanthoscaphites duplico-nodosus Coryell and Salmon, 1934, fragment, $\mathrm{W}=28.3 \mathrm{~mm}, \mathrm{H}=24.8$ mm, Baculites baculus Zone, Pierre Shale, Cedar Creek Anticline, Montana (from Riccardi, 1983, text-fig. 10). D. GSC 67095, Jeletzkytes cf. crassus Riccardi, 1983, W $=19.5 \mathrm{~mm}, \mathrm{H}=16.3 \mathrm{~mm}$, Baculites baculus Zone, Bearpaw Shale, Alberta (from Riccardi, 1983, text-fig. 11). E. GSC 5339a, Jeletzkytes cf. crassus Riccardi, 1983, fragment, W $=32.5 \mathrm{~mm}, \mathrm{H}=25.8 \mathrm{~mm}$, Baculites baculus Zone, Bearpaw Shale, Saskatchewan (from Riccardi, 1983, text-fig. 12). 

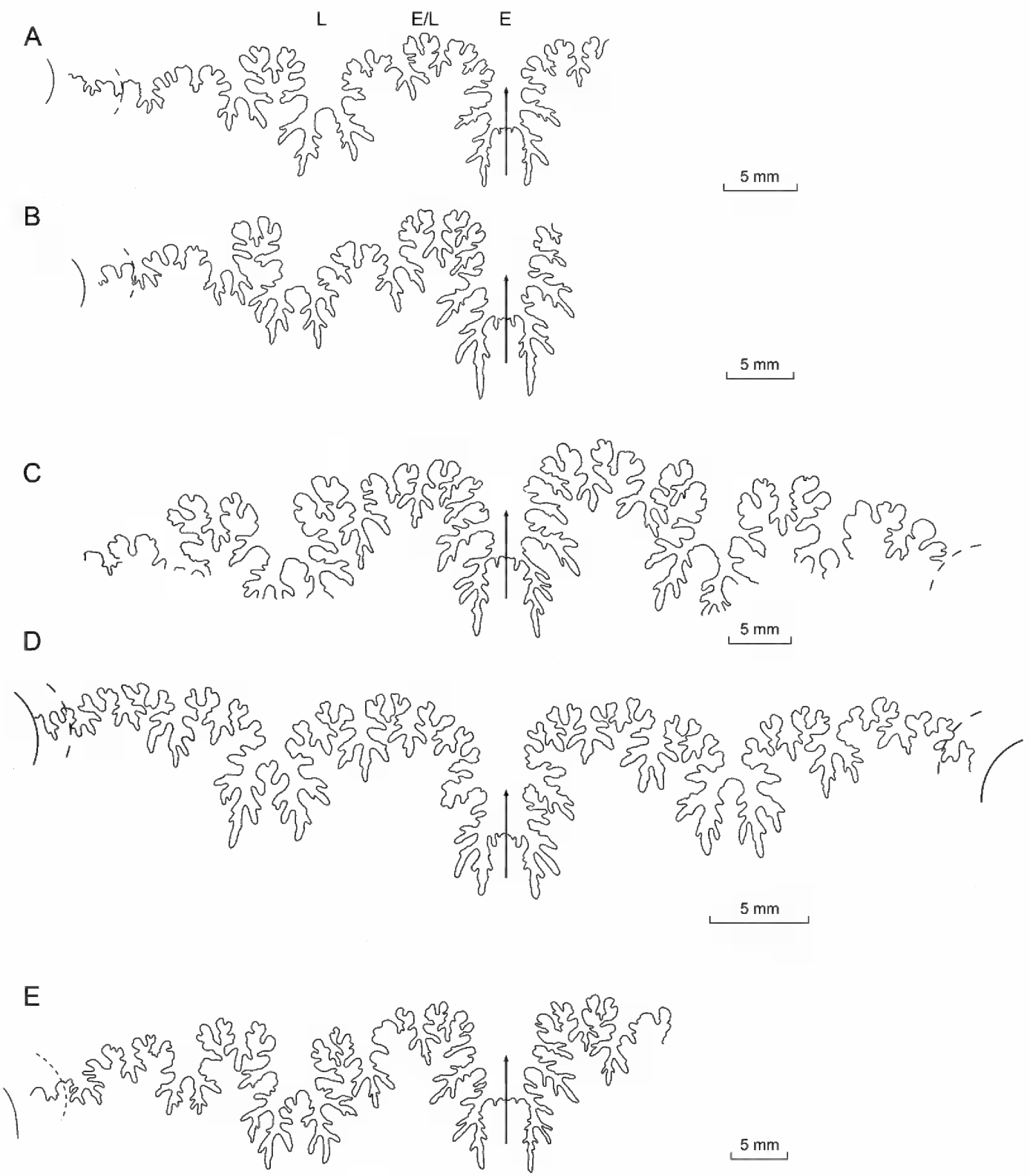

FIGURE 32. Sutures of Hoploscaphites crassus (Coryell and Salmon, 1934), H. plenus (Meek and Hayden 1860), and $H$. peterseni. A. Hoploscaphites crassus, AMNH 76167, microconch, second from last suture, $\mathrm{H}=22.1$ mm, AMNH loc. 3921, lower Baculites baculus Zone, Pierre Shale, Cedar Creek Anticline, Montana. B. Hoploscaphites crassus, AMNH 76166, microconch, fourth from last suture, H=21.5 mm, AMNH loc. 3921, lower Baculites baculus Zone, Pierre Shale, Cedar Creek Anticline, Montana. C. Hoploscaphites plenus, macroconch, BHI 4130, second from last suture, AMNH loc. 3921, Baculites baculus or lower B. grandis Zone, Pierre Shale, Cedar Creek Anticline, Montana. D. Hoploscaphites plenus, microconch, YPM 35597, second from last suture, $\mathrm{W}=18.4 \mathrm{~mm}$, Baculites baculus or lower B. grandis Zone, Pierre Shale, Wibaux (= Mingusville), Montana. E. Hoploscaphites peterseni, macroconch, AMNH 76187, last suture, AMNH loc. 3921, lower Baculites baculus Zone, Pierre Shale, Cedar Creek Anticline, Montana. 
the umbilical shoulder is convex in lateral view. The umbilical bulge is prominent in BHI 4291 (fig. 22) but not as well developed in USNM 723203 (fig. 23).

The whorl section of the phragmocone near the point of exposure is depressed reniform with maximum whorl width at $1 / 3$ whorl height. $\mathrm{W}_{\mathrm{Pl}} /$ $\mathrm{H}_{\mathrm{P} 1}$ averages 1.22 and ranges from 1.06 to 1.43 (1.33 in the holotype). The umbilical wall is steep and subvertical and the umbilical shoulder is sharply rounded. The flanks of the phragmocone are well rounded, as in BHI 4291 (fig. 22), to broadly rounded, as in BHI 4301 (fig. 28), with maximum whorl width at $1 / 3$ whorl height. The ventrolateral shoulder is sharply to well rounded and the venter is broadly rounded.

In passing from the adapical to the adoral part of the phragmocone, the whorl width and height increase, so that the cross section of the shell, as viewed from the ventral side, develops a $\mathrm{V}$-shape, as shown in AMNH 77604 (fig. 24). The whorl section of the phragmocone along the line of maximum length is slightly more depressed than that at the point of exposure. $\mathrm{W}_{\mathrm{P} 2} / \mathrm{H}_{\mathrm{P} 2}$ averages 1.28 and ranges from 1.05 to 1.46 (1.45 in the holotype). The whorl section varies from depressed ovoid, as in BHI 4291 (fig. 22), to depressed reniform, as in the holotype (fig. 13). The umbilical wall is steep and subvertical and the umbilical shoulder is sharply rounded. The inner flanks are well rounded and the outer flanks are broadly rounded and converge toward the venter. The ventrolateral shoulder is sharply rounded and the venter is broadly to well rounded.

In passing from the phragmocone to the shaft, whorl width increases markedly and reaches its maximum value at midshaft forming a swelling at this point, coincident with the position of the umbilical bulge. $\mathrm{W}_{\mathrm{S}} / \mathrm{H}_{\mathrm{S}}$ averages 1.31 and ranges from 1.03 to 1.52 (1.44 in the holotype). The whorl section is depressed reniform with maximum whorl width at $1 / 3$ whorl height. The umbilical wall is steep and convex and the umbilical shoulder is sharply rounded. The inner flanks are well rounded and the outer flanks are broadly rounded and converge toward the venter. The ventrolateral shoulder is sharply rounded and the venter is broadly rounded. $\mathrm{V}_{\mathrm{S}} / \mathrm{H}_{\mathrm{S}}$ averages 0.87 and ranges from 0.69 to 1.05 ( 0.90 in the holotype), indicating that the venter is, on average, nearly as wide as the whorl is high.

Both whorl width and whorl height decrease toward the point of recurvature. This decrease is accentuated in BHI 4301 (fig. 28) in which the shell pinches in approximately $1 \mathrm{~cm}$ adapical of the aperture. This is probably due to an injury or growth deformity. In general, the shape of the whorl section at the point of recurvature is nearly the same as that at midshaft. $\mathrm{W}_{\mathrm{H}} / \mathrm{H}_{\mathrm{H}}$ averages 1.41 and ranges from 1.15 to 1.80 (1.53 in the holotype). The umbilical wall is broad and nearly flat and the umbilical shoulder is sharply rounded. The flanks are well rounded, the ventrolateral shoulder is sharply rounded, and the venter is broadly rounded.

Whorl width and whorl height continue to decrease toward the aperture and, as a result, the aperture is markedly reduced in size relative to the whorl section at midshaft. The aperture is ovoid and nearly equidimensional in AMNH 77604 (fig. 24), whereas it is ovoid and slightly depressed in YPM 35608 (fig. 18). The umbilical wall is broad and nearly flat and the umbilical shoulder is sharply rounded. The flanks are broadly rounded and converge to a narrow, broadly rounded venter.

At the adapical end of the exposed phragmocone, narrow ribs arise at the umbilical seam and cross the umbilical wall slightly rursiradiate. They strengthen across the umbilical shoulder and swing slightly backward and then forward on the inner flanks. If umbilicolateral tubercles are present on the specimen, one rib usually joins an umbilicolateral tubercle dorsally and two or three ribs branch from it ventrally, with one to three ribs intercalating between tubercles. Ribs are straight and rectiradiate on the outer flanks. In SDSM 149986 (fig. 19), the ribs on the right side of the phragmocone are more closely spaced than those on the left side due to an injury. Intercalation and branching 
occur at the ventrolateral tubercles or at their respective locations, and along the outer margins of the outer flanks. One rib usually joins a ventrolateral tubercle dorsally and two ribs branch from it ventrally, with two or three ribs intercalating between tubercles. Ribs are uniformly spaced on the venter, which they cross with a moderately strong adoral projection. The rib density on the venter on the adapical part of the phragmocone ranges from 5 to $7 \mathrm{ribs} / \mathrm{cm}$ (6 ribs/ $\mathrm{cm}$ in the holotype).

The same pattern of ribbing continues onto the adoral part of the phragmocone. Ribs are narrow and slightly rursiradiate on the broad umbilical wall. They strengthen on the umbilical shoulder and are slightly concave on the inner flanks. If umbilicolateral tubercles are present on the specimen, one or two ribs usually join a tubercle dorsally and two or three ribs branch from it ventrally, with one or two ribs intercalating between tubercles. Ribs are straight and rectiradiate on the midflanks, forming a broad area of evenly spaced, nonbifurcating ribs. Branching and intercalation occur at the ventrolateral tubercles and on the outer margins of the outer flanks. One or two ribs usually join a ventrolateral tubercle dorsally and two to four ribs branch from it ventrally. If tubercles are paired on opposite sides of the venter, ribs loop between tubercles, with as many as five nontuberculate ribs intercalating between them. If tubercles are not paired on opposite sides of the venter, ribs that branch from a tubercle on one side of the venter intercalate between pairs of tubercles on the opposite side of the venter. Ribs cross the venter with a moderately strong adoral projection. They are slightly more closely spaced on the adoral than on the adapical part of the phragmocone. The rib density on the venter on the adoral part of the phragmocone ranges from 6 to $8 \mathrm{ribs} / \mathrm{cm}$ ( $8 \mathrm{ribs} / \mathrm{cm}$ in the holotype).

Ribs are not preserved on the shaft of the holotype but are preserved in many other specimens such as BHI 4291 (fig. 22) and AMNH 134699 (fig. 15). In BHI 4291 (fig. 22), 9 ribs $/ \mathrm{cm}$ are present on the umbilical wall at midshaft. On the adapical one-third of the shaft, ribs are slightly concave on the inner flanks but straighten out on the outer flanks. Starting at midshaft, ribs are broadly concave on both the inner and outer flanks; they become progressively more prorsiradiate and widely spaced toward the aperture. One or two ribs usually join an umbilicolateral tubercle dorsally and three or four ribs branch from it ventrally, with four or five ribs intercalating between tubercles. Intercalation and branching also occur at the ventrolateral tubercles. Two or three ribs usually join a ventrolateral tubercle dorsally and four or five ribs branch from it ventrally. As on the phragmocone, if tubercles are paired on opposite sides of the venter, ribs loop between tubercles, with three to five nontuberculate ribs intercalating between them. If tubercles are not paired on opposite sides of the venter, ribs that branch from a tubercle on one side of the venter intercalate between pairs of tubercles on the opposite side of the venter. Ribs are evenly and closely spaced on the venter, which they cross with a moderately strong adoral projection. The rib density on the venter at midshaft ranges from 4 to $9 \mathrm{ribs} / \mathrm{cm}$ ( $7 \mathrm{ribs} / \mathrm{cm}$ in the holotype).

The same pattern of ribbing persists onto the hook. Ribs swing forward at the umbilical shoulder and are broadly concave on the flanks. Intercalation and branching occur at the umbilicolateral and ventrolateral tubercles. Ribs cross the venter with a slight adoral projection. 'The rib density on the venter of the hook is similar to that at midshaft and ranges from 6 to $9 \mathrm{ribs} / \mathrm{cm}$ (7 in the holotype).

Umbilicolateral tubercles are usually present at the point of exposure, having migrated out from a more dorsal position in earlier whorls. They occur at $1 / 3$ whorl height. They are closely spaced, gradually becoming more widely spaced toward the adoral end of the phragmocone. The maximum distance between consecutive tubercles on the phragmocone ranges from 4 to $7.5 \mathrm{~mm}$. The total number of umbilicolateral tubercles on the exposed phragmocone ranges from 5 to 13 (13 in the holotype); BHI 4291 (fig. 22) bears 9 

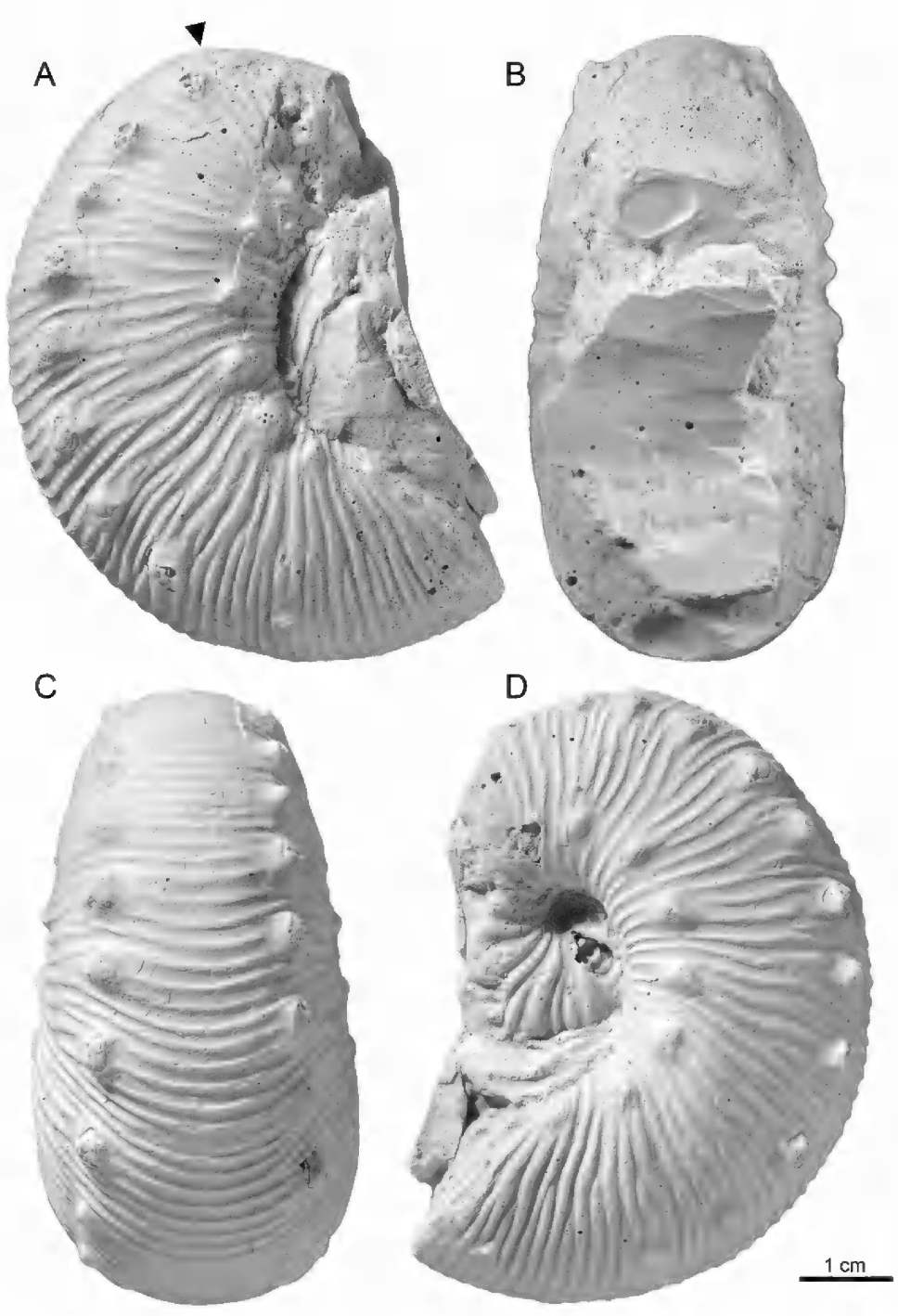

FIGURE 33. Hoploscaphites crassus (Coryell and Salmon, 1934), microconch. A-D. USNM 365 (= cast of paratype, Scaphites nodosus quadrangularis illustrated by Meek, 1876: pl. 25, fig. 4), Baculites baculus or lower B. grandis Zone, Pierre Shale, Cedar Creek Anticline, east-central Montana. A, Right lateral; B, apertural; C, ventral; D, left lateral. Arrow indicates the base of the body chamber.

umbilicolateral tubercles on the phragmocone. In contrast, umbilicolateral tubercles are absent altogether in AMNH 135326 (fig. 26).

The umbilicolateral tubercles on the phragmocone range in height from 0.25 to 1.0 $\mathrm{mm}$. They are bullate and elongated radially. As mentioned previously, one or two ribs usually join an umbilicolateral tubercle dorsally and two or three ribs branch from it ventrally. However, in USNM 723203 (fig. 23), the ribs that join an umbilicolateral tubercle dorsally are very broad and, in some instances, even comprise two ribs fused together. Moreover, in the holotype (fig. 13), some of the umbilicolateral tubercles do not occur on ribs at all, but rather in the interspaces between them.

Umbilicolateral tubercles occur at $1 / 3$ to nearly $1 / 2$ whorl height on the body chamber. The 


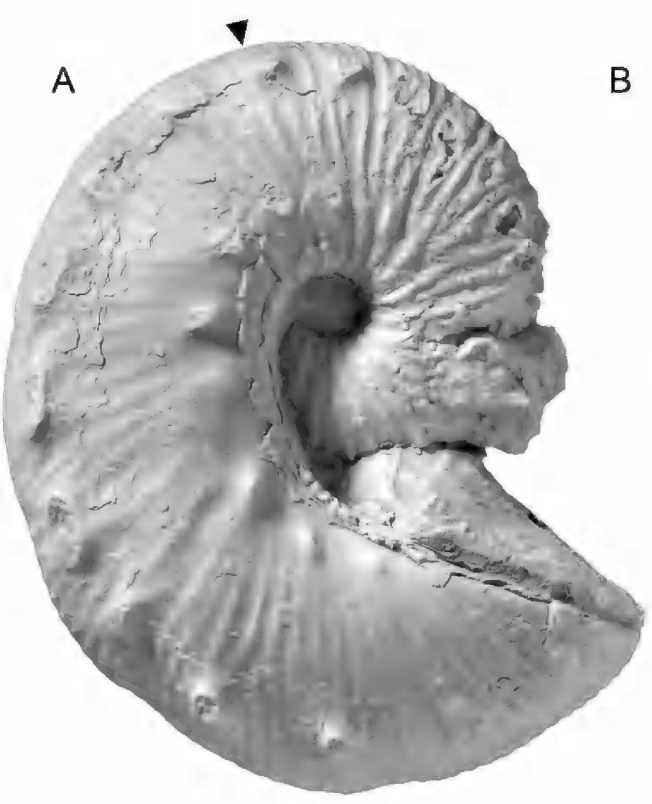

B
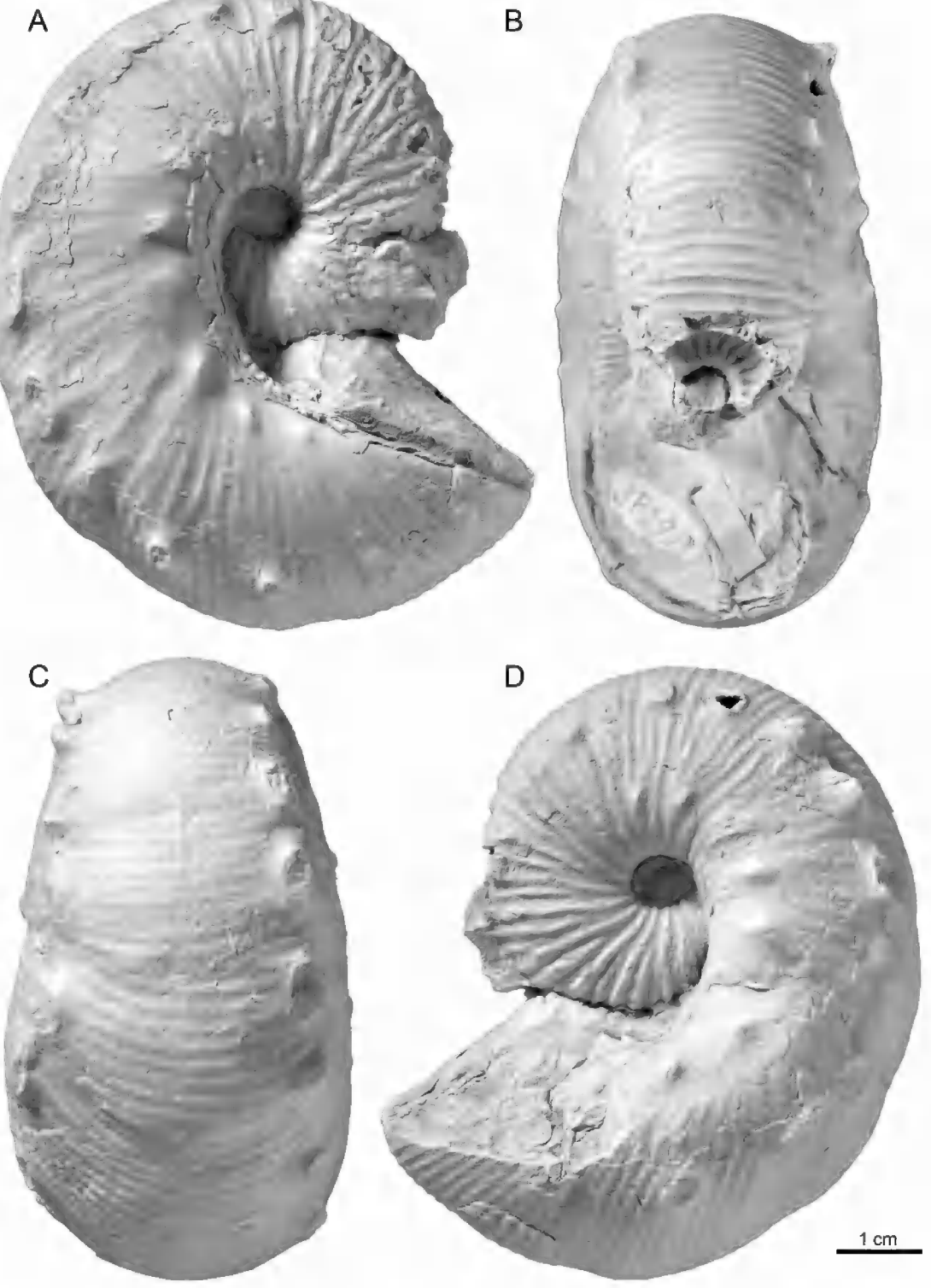

FIGURE 34. Hoploscaphites crassus (Coryell and Salmon, 1934), microconch. A-D. AMNH 105905, AMNH loc. 3921, lower Baculites baculus Zone, Pierre Shale, Cedar Creek Anticline, east-central Montana. A, Right lateral; B, apertural; C, ventral; D, left lateral. Arrow indicates the base of the body chamber.

number of umbilicolateral tubercles on the body chamber ranges from 3 to 8 ( 5 in the holotype), with the exception of AMNH 135326 (fig. 26), in which they are absent altogether. Excluding this specimen, the total number of umbilicolateral tubercles on the exposed shell ranges from 9 to
20 (20 in the holotype). The umbilicolateral tubercles attain their maximum spacing at midshaft and usually become more closely spaced thereafter. They usually persist to the aperture, as in the holotype (fig. 13) and BHI 4291 (fig. 22). The tubercles are bullate but terminate in sharp 

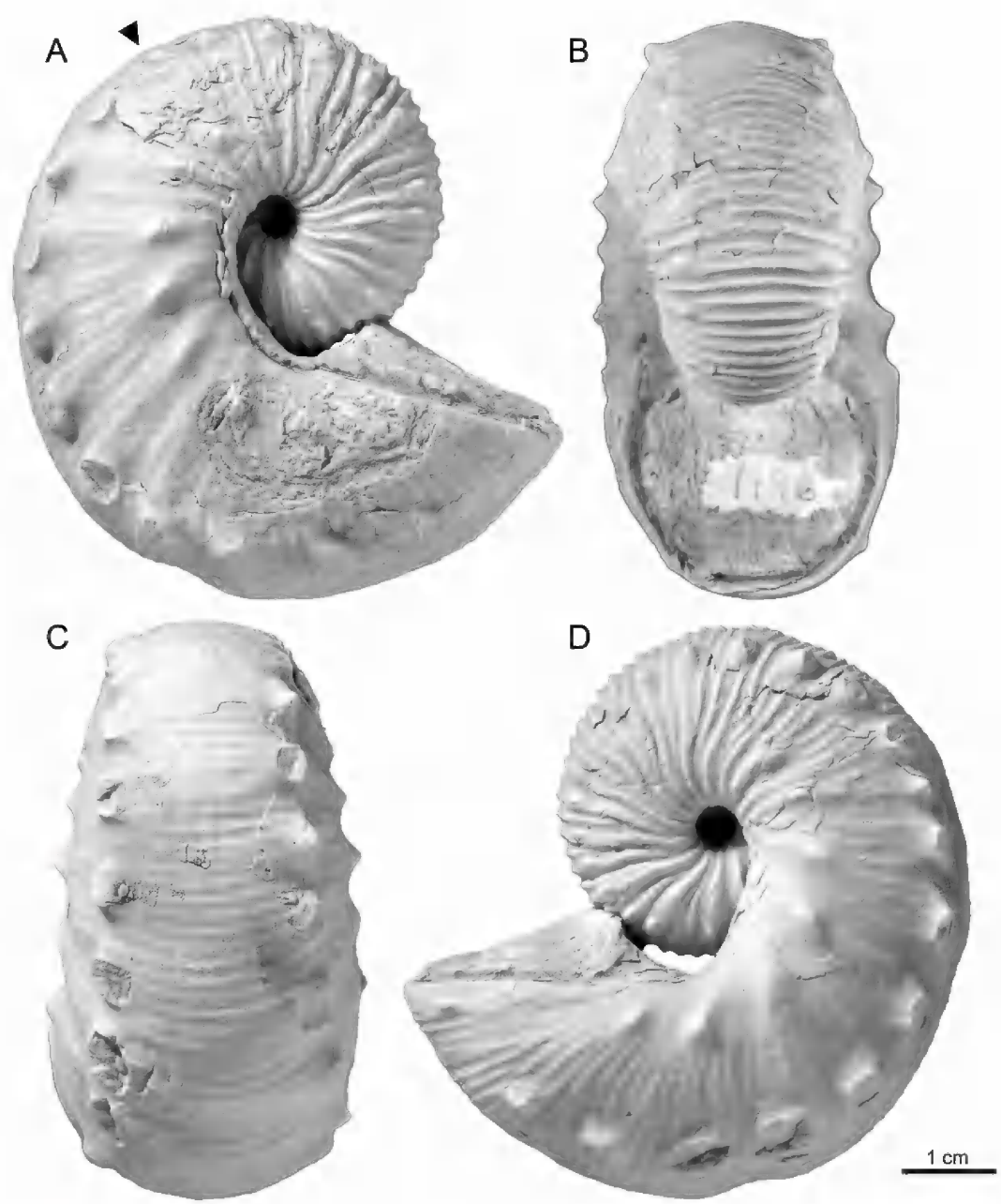

FIGURE 35. Hoploscaphites crassus (Coryell and Salmon, 1934), microconch. A-D. ANSP IP 33670, Baculites baculus or lower B. grandis Zone, Pierre Shale, Cedar Creek Anticline, east-central Montana. A, Right lateral; B, apertural; C, ventral; D, left lateral. Arrow indicates the base of the body chamber.

points. They are relatively more prominent in smaller specimens, such as BHI 4891 (fig. 22), than in larger specimens, such as SDSM 149986 (fig. 19). The maximum height of tubercles ranges from $1.5-2 \mathrm{~mm}$.

Even in specimens in which umbilicolateral tubercles are absent or reduced in size such as AMNH 135326 (fig. 26) and SDSM 149987 (fig. 27), ventrolateral tubercles are present starting at the point of exposure. They occur at $3 / 4$ to $7 / 8$ whorl height and may be paired or offset on opposite sides of the venter. The total number of ventrolateral tubercles on the exposed phragmocone ranges from 7 to 17, depending on the size of the shell (17 in the holotype). They are more or less evenly spaced, becoming progressively more widely spaced toward the base of the body chamber, with the maximum distance between tubercles ranging from 6 to $15 \mathrm{~mm}$ (12 $\mathrm{mm}$ in the holotype). We note, however, many exceptions to this pattern. In YPM 35608 (fig. 18), the tubercles are grouped in pairs, and in BHI 4291 (fig. 22), three of the most closely spaced tubercles occur near the adoral end of the phragmocone.

As mentioned in describing the phragmocone, one or two ribs usually join a ventrolateral 

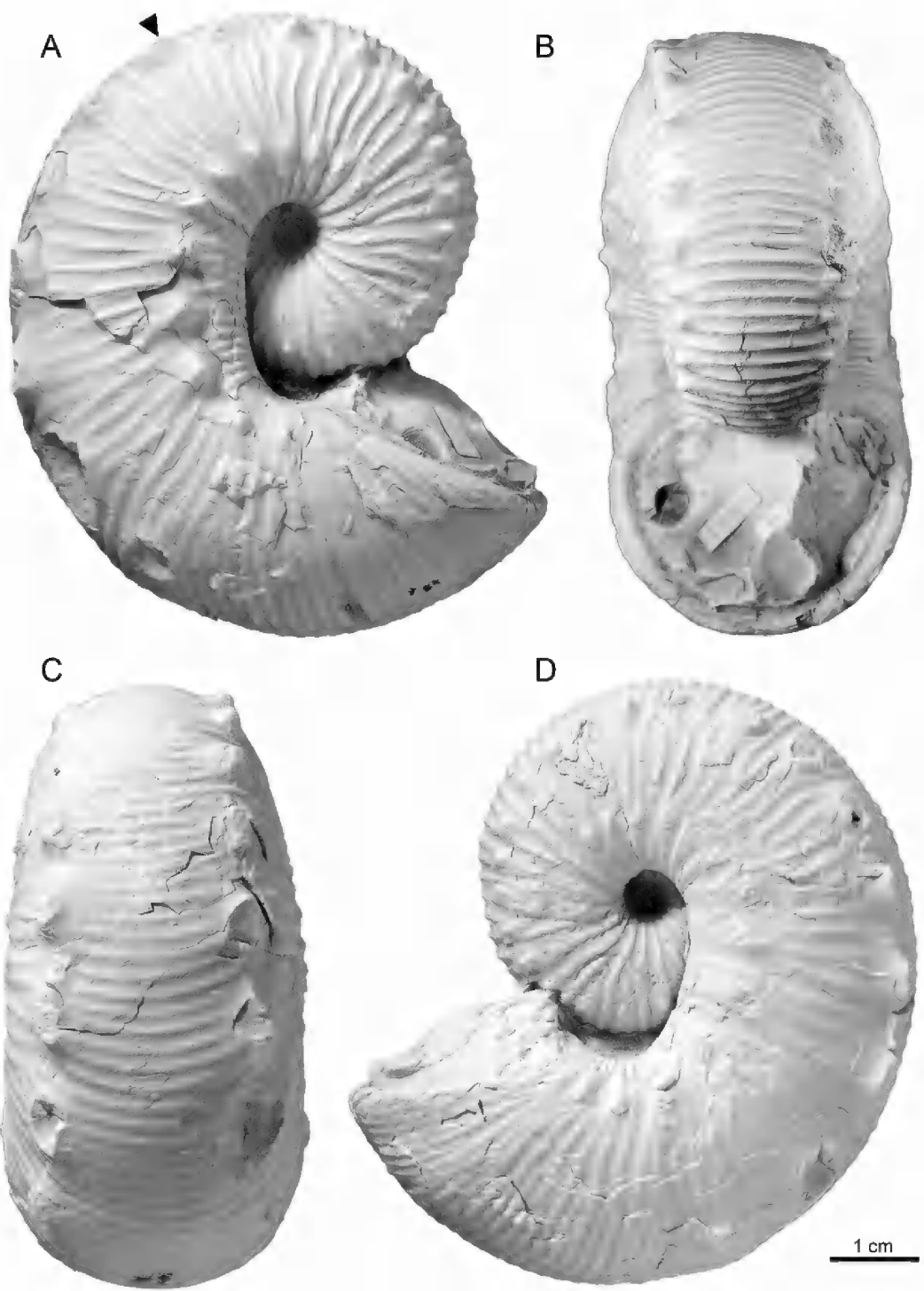

FIGURE 36. Hoploscaphites crassus (Coryell and Salmon, 1934), microconch. A-D. USNM 723215, Baculites baculus Zone, Pierre Shale, Cedar Creek Anticline, east-central Montana. A, Right lateral; B, apertural; C, ventral; D, left lateral. Arrow indicates the base of the body chamber.

tubercle dorsally and two to four ribs branch from it ventrally. However, in many specimens such as BHI 4291 (fig. 22) and SDSM 149987 (fig. 27), some of the ventrolateral tubercles occur in the interspaces between ribs. The tubercles on the phragmocone are radially elongated but terminate in sharp points. As shown in USNM 723203 (fig. 23), tubercles usually exhibit steeply sloping adapical faces and more gently sloping adoral faces. They range in height from 1.0-2.5 mm.

Ventrolateral tubercles continue onto the body chamber, usually persisting right to the aperture. They occur at $7 / 8$ whorl height and are paired or slightly offset on opposite sides of the venter. The total number of ventrolateral tubercles on the body chamber ranges from 8 to 15 (13 in the holotype), so that the 

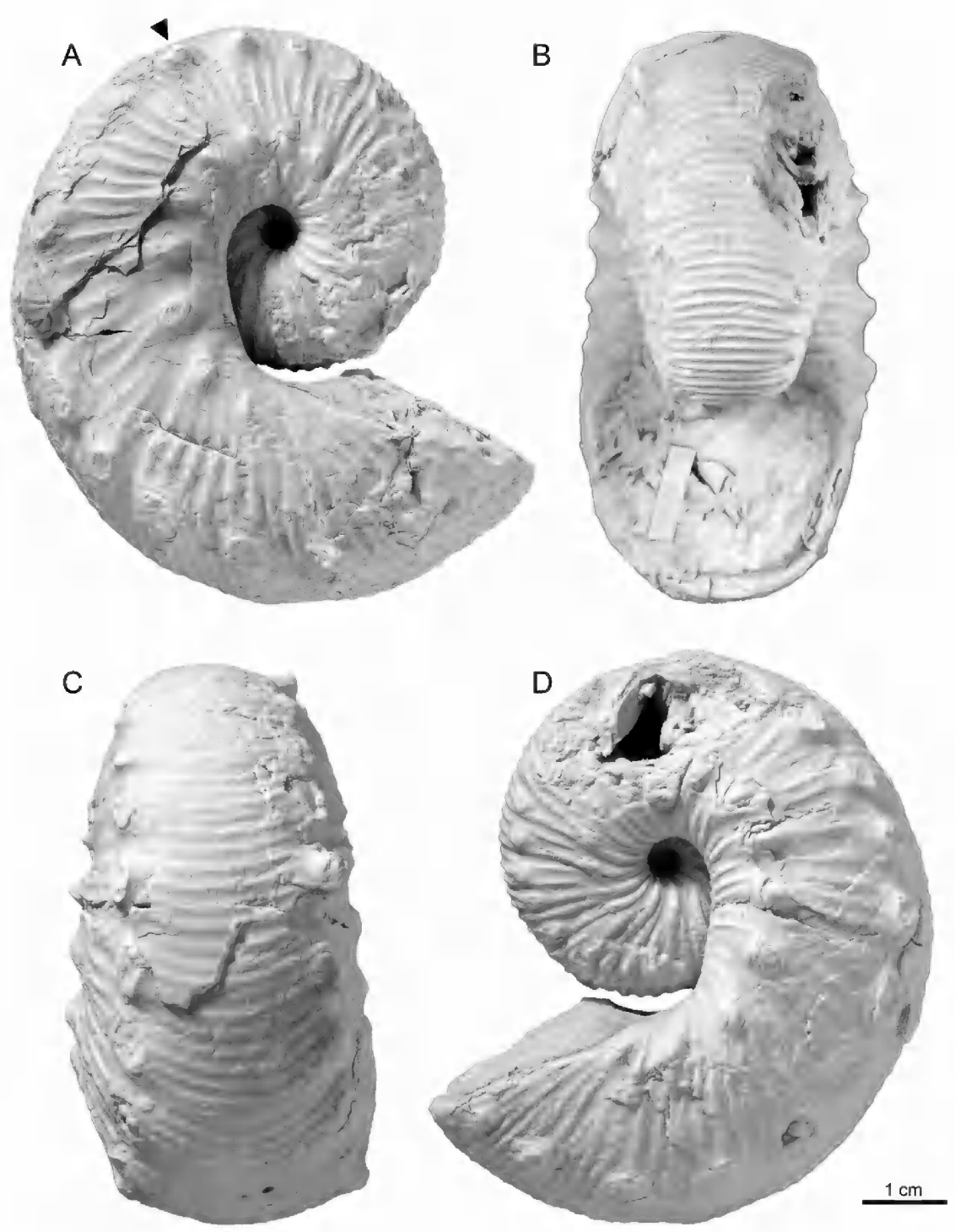

FIGURE 37. Hoploscaphites crassus (Coryell and Salmon, 1934), microconch. A-D. AMNH 76166, AMNH loc. 3921, lower Baculites baculus Zone, Pierre Shale, Cedar Creek Anticline, east-central Montana. A, Right lateral; B, apertural; C, ventral; D, left lateral. Arrow indicates the base of the body chamber.

total number of ventrolateral tubercles on the exposed shell ranges from 21 to 36 (30 in the holotype). Tubercles gradually become more widely spaced adorally, and attain their maximum spacing at midshaft or on the adoral one-third of the shaft. The maximum distance between consecutive tubercles ranges from 7 to $18 \mathrm{~mm}$ (12 $\mathrm{mm}$ in the holotype). Thereafter, the spacing between tubercles decreases toward the aperture, as shown in the holotype (fig. 13). Exceptions to this rule are BHI 4292 (fig. 25), AMNH 135326 (fig. 26), and ANSP IP 81678 (fig. 30), in which the distance between tubercles remains nearly the same on the entire body chamber, a pattern that is similar to that in Hoploscaphites plenus.

Ventrolateral tubercles usually attain their maximum height on the adoral one-third of the 

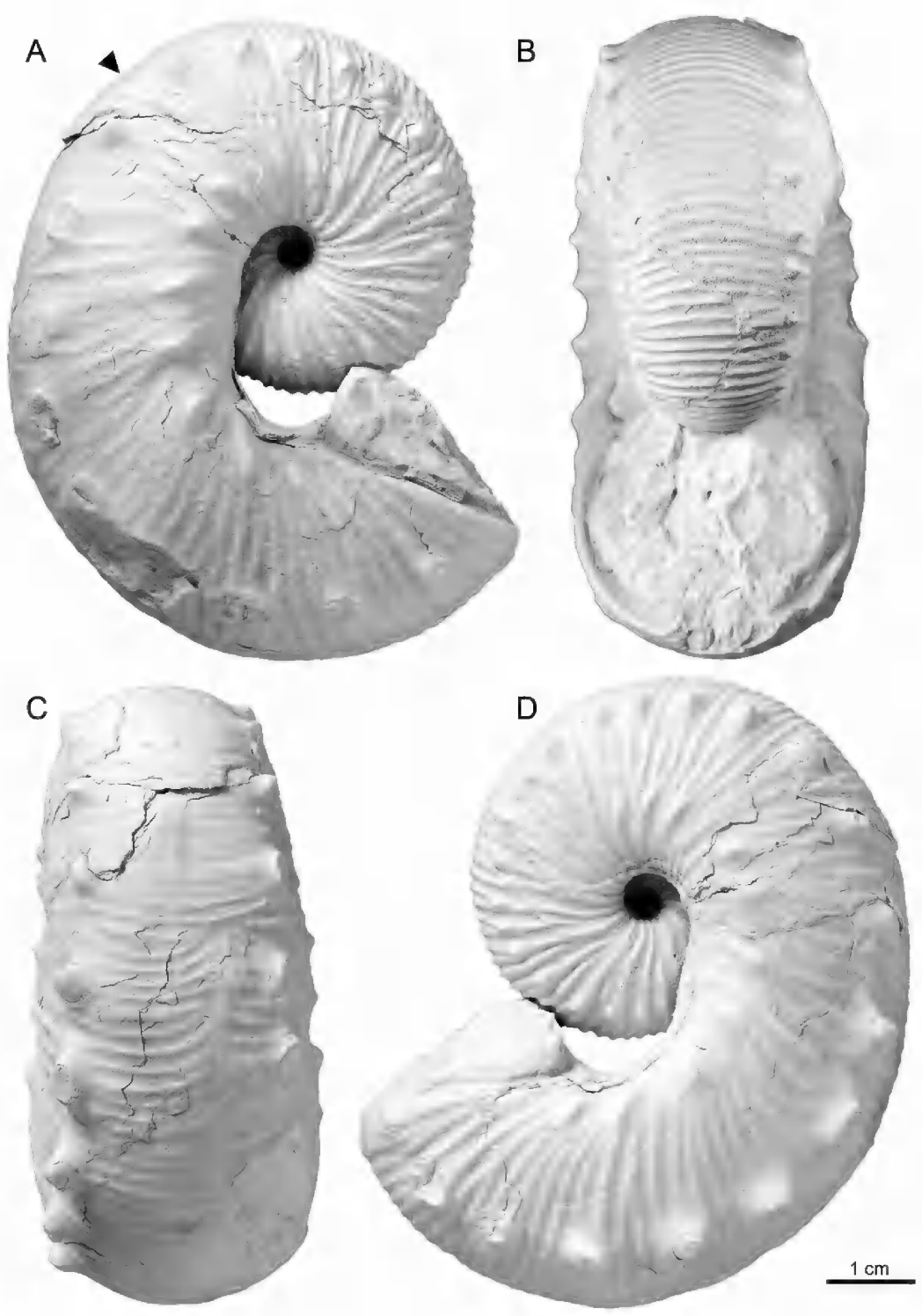

FIGURE 38. Hoploscaphites crassus (Coryell and Salmon, 1934), microconch. A-D. SDSM 149989, Baculites baculus Zone, Pierre Shale, Cedar Creek Anticline, east-central Montana. A, Right lateral; B, apertural; C, ventral; D, left lateral. Arrow indicates the base of the body chamber.

shaft. They range in height from $2 \mathrm{~mm}$, as in the holotype (fig. 13), to $5 \mathrm{~mm}$, as in $\mathrm{AMNH}$ 135326 (fig. 26). However, in general, tubercles do not attain the size of those in Hoploscaphites plenus. Smaller tubercles ( $2 \mathrm{~mm}$ high) are conical in shape whereas larger tubercles $(5 \mathrm{~mm}$ high) are clavate in shape, with steep adapical and gently sloping adoral faces.
Lateral tubercles are absent in all the specimens we examined. The only possible exception is SDSM 149983 (fig. 21), in which two ribs become slightly bullate just dorsal of the ventrolateral tubercles on the adapical end of the phragmocone.

The suture is deeply incised. The first lateral saddle $(\mathrm{E} / \mathrm{L})$ is broad stemmed and asymmetri- 

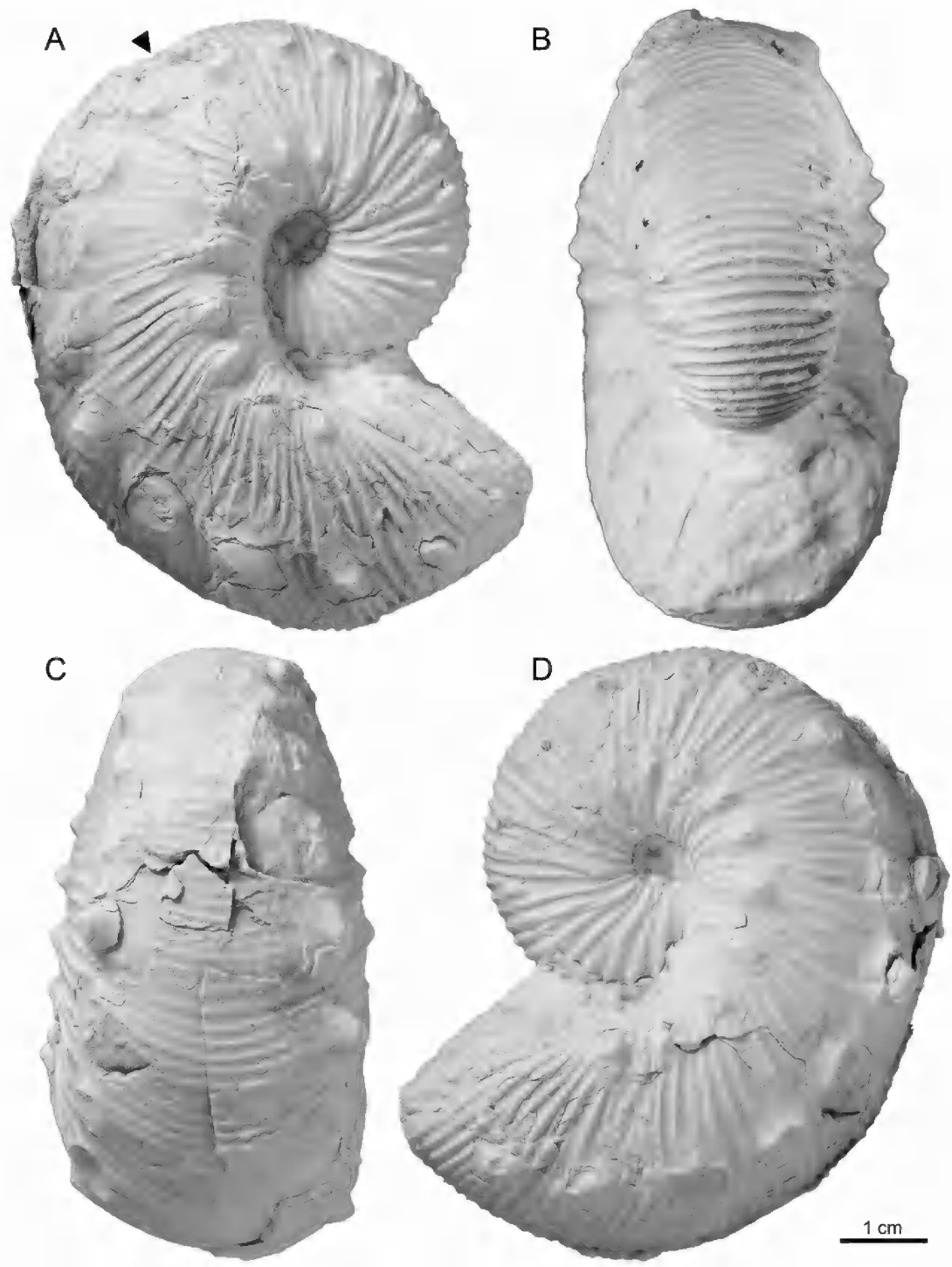

FIGURE 39. Hoploscaphites crassus (Coryell and Salmon, 1934), microconch. A-D. AMNH 134700, AMNH loc. 3921, lower Baculites baculus Zone, Pierre Shale, Cedar Creek Anticline, east-central Montana. A, Right lateral; B, apertural; C, ventral; D, left lateral. Arrow indicates the base of the body chamber.

cally bifid, with the ventral branch larger than the dorsal branch. The first lateral lobe (L) is narrow, symmetrically bifid, and nearly as deep as the ventral lobe (fig. 31).

Microconch Description: What we take to be microconchs of this species are robust, loosely uncoiled forms, with the same pattern of ornamentation as on the macroconchs. LMAX aver- ages $67.4 \mathrm{~mm}$ and ranges from 57.7 to $78.3 \mathrm{~mm}$ (table 2). The size distribution is unimodal and asymmetric with a peak at 70-75 mm (fig. 12). The ratio of the average size of microconchs to that of macroconchs is 0.66 .

UD averages $4.2 \mathrm{~mm}$ and ranges from 3.4 to $5.1 \mathrm{~mm}$. UD/LMAX averages 0.06 and ranges from 0.04 to 0.08 . The umbilical seam of the 

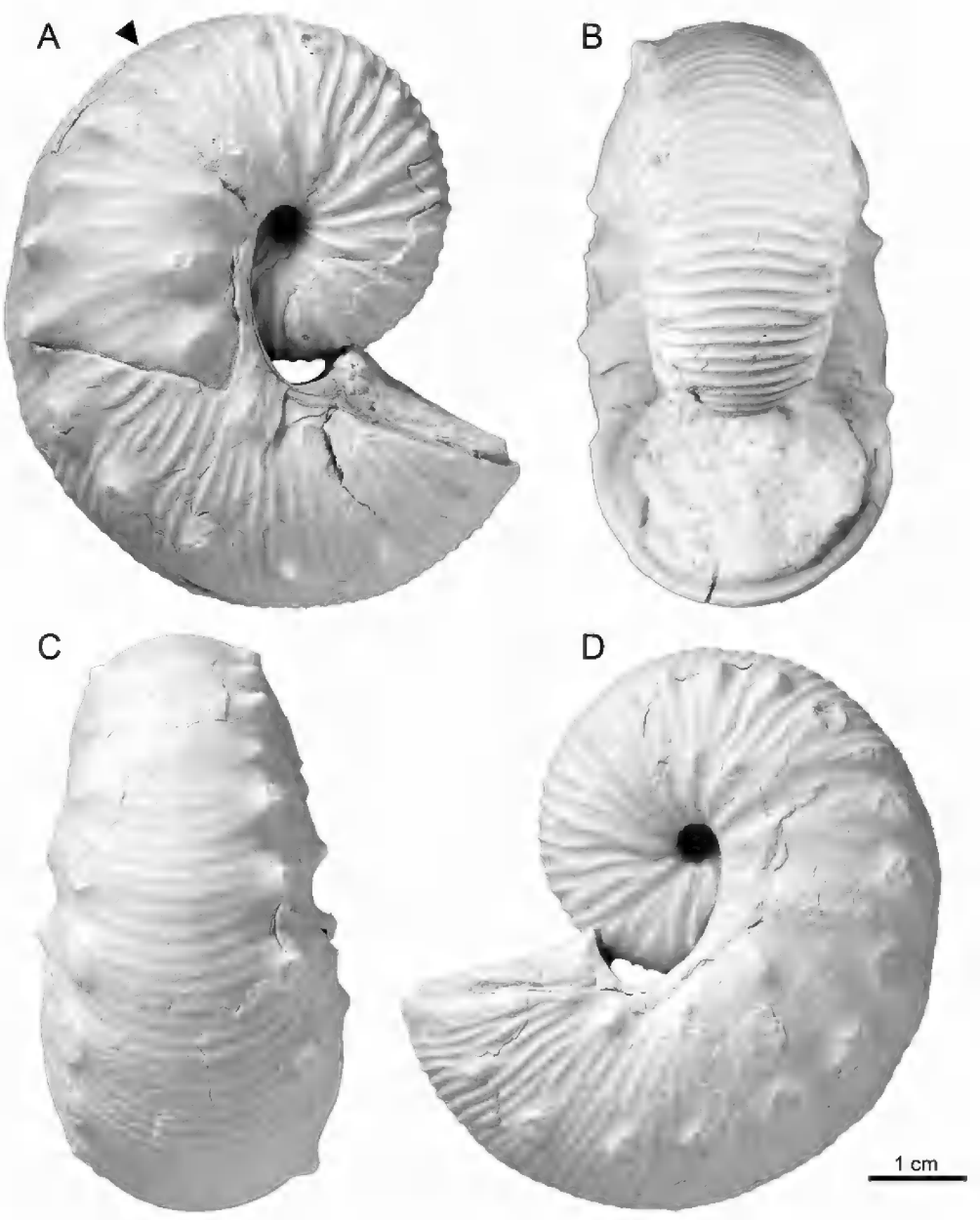

FIGURE 40. Hoploscaphites crassus (Coryell and Salmon, 1934), microconch. A, B. SDSM 149988, Baculites baculus Zone, Pierre Shale, Cedar Creek Anticline, east-central Montana. A, Right lateral; B, apertural. C, D. AMNH 76167, AMNH loc. 3921, lower Baculites baculus Zone, Pierre Shale, Cedar Creek Anticline, eastcentral Montana. C, ventral; D, left lateral. Arrow indicates the base of the body chamber.

shaft is concave in lateral view, as in other microconchs of Hoploscaphites. All specimens are robust with an oval outline in lateral view. In addition, microconchs are more loosely uncoiled than macroconchs. $\mathrm{LMAX} / \mathrm{H}_{\mathrm{P} 2}$ averages 2.96 , which is significantly higher than that in macroconchs (2.78).

The whorl section of the exposed phragmocone is depressed subquadrate. $\mathrm{W}_{\mathrm{P} 1} / \mathrm{H}_{\mathrm{P} 1}$ averages 1.08 and ranges from 0.90 to 1.24 (table 2 ). $\mathrm{W}_{\mathrm{P} 2} /$ $\mathrm{H}_{\mathrm{P} 2}$ averages 1.16 and ranges from 1.05 to 1.28 . The umbilical wall is steep and subvertical and the umbilical shoulder is sharply rounded. The inner flanks are sharply rounded and the outer flanks are broadly rounded, with maximum whorl width at $1 / 3$ whorl height. The ventrolateral shoulder is sharply rounded and the venter is well rounded.

Whorl width increases gradually from the phragmocone into the body chamber and attains its maximum value at the point of recurvature. Whorl height also increases gradually and attains its maximum value at midshaft, and remains nearly the same thereafter. The whorl section at 


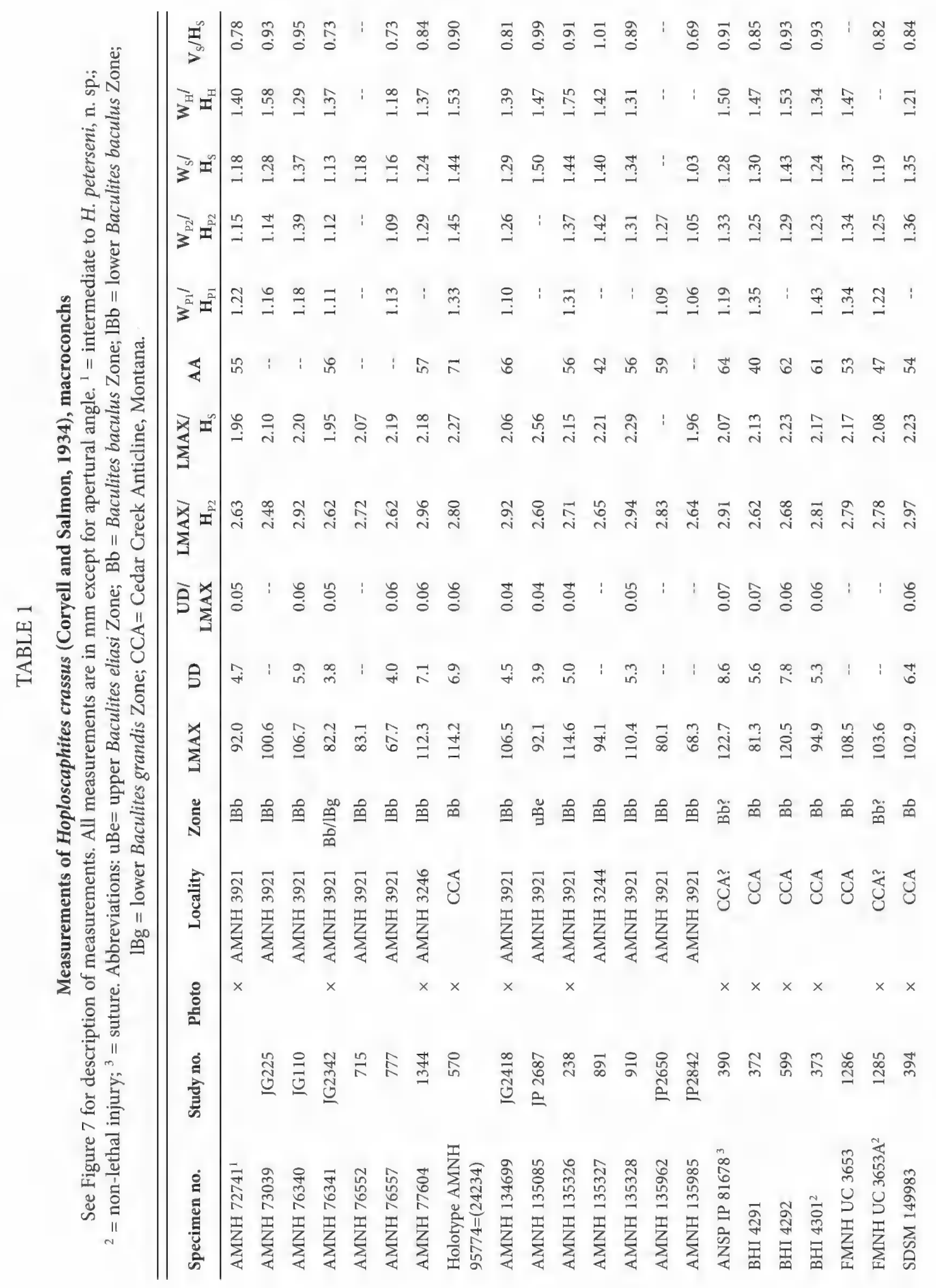




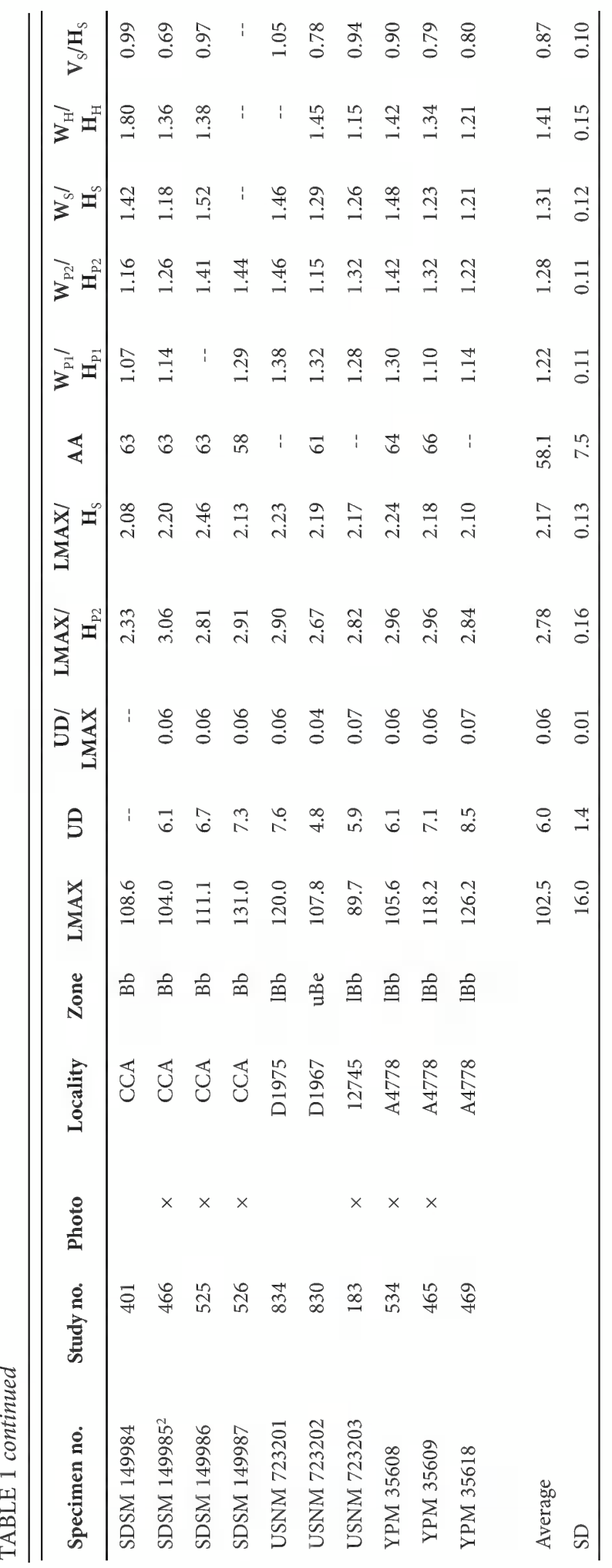


midshaft is depressed reniform with maximum whorl width at $1 / 3$ whorl height. Ws/Hs averages 1.22 and ranges from 1.09 to 1.38 (table 2). The umbilical wall is steep and slopes outward, and the umbilical shoulder is sharply rounded. The flanks are broadly rounded, the ventrolateral shoulder is sharply rounded, and the venter is broadly rounded. $\mathrm{V}_{\mathrm{S}} / \mathrm{H}_{\mathrm{S}}$ averages 0.87 and ranges from 0.72 to 1.05 , indicating that, on average, the venter is nearly as wide as the whorl is high. The whorl section at the point of recurvature is more ovate than that at midshaft. $\mathrm{W}_{\mathrm{H}} / \mathrm{H}_{\mathrm{H}}$ averages 1.29 and ranges from 1.19 to 1.42 .

Ornament in microconchs is similar to that in macroconchs. On the exposed phragmocone, narrow ribs arise at the umbilical seam and strengthen across the umbilical shoulder. They bend slightly backward on the inner flanks and slightly forward on the outer flanks, forming a broad convexity. On the adoral end of the phragmocone, one rib usually joins an umbilicolateral tubercle dorsally and two ribs branch from it ventrally, with one rib intercalating between tubercles. As on macroconchs, intercalation and branching also occur at the ventrolateral tubercles and along the outer margins of the outer flanks. One or two ribs usually join a ventrolateral tubercle dorsally and two or three ribs branch from it ventrally, with one or two ribs intercalating between tubercles. Ribs are uniformly spaced on the venter, which they cross with a moderately strong adoral projection. The rib density on the venter on the adoral part of the phragmocone ranges from 6 to $8 \mathrm{ribs} / \mathrm{cm}$.

Ribs are strong and moderately widely spaced on the shaft. They swing slightly backward on the umbilical wall and inner flanks, slightly forward on the midflanks, and slightly backward again on the outer flanks. They become progressively more prorsiradiate toward the adoral end of the shaft. Intercalation and branching occur at the umbilicolateral and ventrolateral tubercles, as exemplified by USNM 365 (fig. 33). In this specimen, two ribs join an umbilicolateral tubercle dorsally, and three ribs branch from it ventrally, with two ribs intercalating between tubercles.
Two or three ribs join a ventrolateral tubercle dorsally, and an equal number of ribs branch from it ventrally. In areas where tubercles are paired on opposite sides of the venter, ribs loop between tubercles, with two or three nontuberculate ribs intercalating between them. In areas where tubercles are not paired on opposite sides of the venter, ribs that branch from a tubercle on one side of the venter intercalate between pairs of tubercles on the opposite side of the venter. Ribs are evenly and closely spaced on the venter, which they cross with a moderately strong adoral projection. The rib density on the venter at midshaft in USNM 365 is 6 ribs $/ \mathrm{cm}$, which remains the same on the hook (fig. 33).

Umbilicolateral tubercles are present in all specimens and first appear on the adoral end of the phragmocone. They occur at $1 / 3$ whorl height and are more prominent in microconchs than in macroconchs. They strengthen on the shaft and develop into bullae, with a maximum height of 3 $\mathrm{mm}$. Many of the tubercles exhibit steep adapical faces and gently sloping adoral faces. The tubercles become progressively more widely spaced adorally, and attain their maximum spacing on the adoral one-third of the shaft, after which they become more closely spaced again toward the aperture. The maximum distance between consecutive tubercles on the adoral one-third of the shaft in USNM 365 is $7 \mathrm{~mm}$ (fig. 33).

Ventrolateral tubercles are present starting at the point of exposure. In SDSM 149989 (fig. 38 ), in which the ornamentation is very well preserved, a total of 17 ventrolateral tubercles appear on the phragmocone. They occur at $7 / 8$ whorl height and are more or less evenly spaced, gradually becoming more widely spaced toward the adoral end of the phragmocone. The distance between consecutive tubercles in this specimen increases from $4 \mathrm{~mm}$ on the adapical end of the phragmocone to $8 \mathrm{~mm}$ on the adoral end of the phragmocone. Tubercles are usually paired on opposite sides of the venter but, occasionally, they are offset. They are conical in shape but elongated radially, with a maximum height of $3 \mathrm{~mm}$. 
Ventrolateral tubercles continue uninterruptedly to the aperture. In SDSM 149989 (fig. 38), nine ventrolateral tubercles appear on the body chamber, so that the total number of tubercles on the exposed shell of this specimen is 26 . Tubercles become increasingly larger and more clavate on the shaft, reaching a maximum height of 4 $\mathrm{mm}$. They exhibit steep adapical faces and gently sloping adoral faces. Tubercles gradually become more widely spaced toward the adoral one-third of the shaft. In our sample of specimens, the maximum distance between consecutive tubercles in this area ranges from 10 to $16 \mathrm{~mm}$. Tubercles become more closely spaced toward the aperture and, in some instances, disappear altogether, as shown in USNM 723215 (fig. 36).

The suture of microconchs is similar to that of macroconchs (fig. 32A, B).

Discussion: Hoploscaphites crassus is characterized by a globose shell with strongly inflated flanks and small, evenly spaced ventrolateral tubercles. It most closely resembles $H$. plenus, from which it differs in having more numerous, smaller, and more closely spaced ventrolateral tubercles, and a more robust whorl section. For example, the average value of $\mathrm{V}_{S} / \mathrm{H}_{\mathrm{S}}$ in macroconchs of $H$. crassus is significantly higher than that in macroconchs of $H$. plenus (0.87 vs 0.68 ). However, $H$. crassus clearly shows much morphology in common with $H$. plenus. Riccardi (1983: 21) also recognized this fact and cautioned that "more material is necessary to establish the ranges of their morpholgical variability and hence definite validity." We retain the two as separate species because of discernable differences but acknowledge the existence of intermediate specimens that share features of both species. Hoploscaphites crassus is easily distinguished from the slightly younger $H$. criptonodosus (Riccardi, 1983) by its more inflated whorl section and lack of lateral tubercles.

OCCURRence: Hoploscaphites crassus is restricted to the upper part of the Baculites eliasi and the lower part of the B. baculus zones. It occurs in the Pierre Shale on the Cedar Creek
Anticline, east-central Montana, the Pierre Shale on the Old Woman Anticline in Niobrara County, Wyoming, the Lewis Shale in Carbon County, Wyoming, and the Bearpaw Shale in Valley and Stillwater counties, Montana. On the Cedar Creek Anticline, it is most abundant in the scaphite and septarian concretionary layers in the lower part of the $B$. baculus Zone. Hoploscaphites crassus is also reported from the B. eliasi and B. baculus zones in Saskatchewan and Alberta (Riccardi, 1983).

Hoploscaphites plenus (Meek and Hayden, 1860)

Figures 10C, D, 32C, D, 41-58

Macroconch Synonymy

1860a. Scaphites nodosus var. plenus. Meek and Hayden, p. 177.

1860b. Scaphites nodosus var. plenus. Meek and Hayden, p. 420.

1861. Scaphites nodosus var. plenus. Gabb, p. 33.

1864. Scaphites nodosus var. plenus Meek and Hayden. Meek, p. 24.

1876. Scaphites nodosus Owen var. plenus Meek and Hayden. Meek, p. 429, pl. 26, fig. 1a-c.

?1899. Scaphites nodosus Meek. Logan, p. 209, pl.

22, fig. 2; pl. 23, figs. $1-4,6-12$

(unidentifiable because only sutures and drawings of early ontogenetic stages).

1905. Scaphites nodosus plenus Meek and

Hayden. Schuchert, p. 588.

?1905. Scaphites nodosus var. plenus Meek and Hayden. Smith, p. 638, figs. 1.1; 3.4, 7, 8, 10 (unidentifiable because only sutures and early ontogenetic stages).

1916. Scaphites nodosus plenus. Nowak, p. 59. 1927. Acanthoscaphites nodusus var. plenus.

Reeside, p. 32.

1933. Scaphites plenus Meek. Elias, p. 314 (pars), pl. 36, fig. 1a-c, 2a-c (unidentifiable because only early ontogenetic stages); pl. 37, fig. la-c (unidentifiable because only early ontogenetic stage); pl. 39, fig. 1a-c (unidentifiable because only early 
ontogenetic stage); pl. 40, figs. 3-5

(unidentifiable because sutures of only early ontogenetic stages), fig. 6 (= Meek, 1876, pl. 26, fig. 1c).

1934. Acanthoscaphites nodosus plenus. Coryell and Salmon, p. 11.

1940. Acanthoscaphites plenus. Landes, p. 178.

1977. Hoploscaphites nodosus plenus (Meek and Hayden). Kauffman, p. 274, pl. 32, fig. 1 (= Meek, 1876, pl. 26, fig. 1a).

1980. Hoploscaphites nodosus plenus. Thomel, fig. 111.

1983. Jeletzkytes plenus (Meek). Riccardi, p. 21, pl. 9, figs. 1, 2; text-fig. 13a (= cross section of Meek, 1876, pl. 26, fig. 1a).

?1983. Jeletzkytes aff. brevis (Meek) + . Riccardi, p. 27, pl. 6, figs. 1-4; text fig. 23 (suture); text fig. 24 (cross section).

1997. Jeletzkytes plenus (Meek and Hayden, 1860).

Larson et al., p. 80, unnumbered figs.

non 2010. Hoploscaphites plenus (Meek, 1876). Landman, p. 50, fig 2A, B; p. 198, fig. 86E-G.

2016. Jeletzkytes plenus (Meek and Hayden, 1861). Klein, p. 143.

Microconch Synonomy

1876. Scaphites nodosus var. quadrangularis Meek, p. 248 (pars), pl. 25, fig. 3a-c only; non fig. 2a-c (= Hoploscaphites brevis microconch); non fig. 4 (= Hoploscaphites crassus microconch).

1910. Scaphites nodosus quadrangularis (Meek). Grabau and Shimer, p. 177, figs. 1429, 1430 (= Meek, 1876, pl. 25, figs. 3a-c).

1915. Scaphites binodosus F.A. Roemer var. quadrangularis Meek. Frech, p. 559, text-fig. 5.

1921. Scaphites nodosus var. quadrangularis. Grabau, p. 701, fig. 1698h (= Meek, 1876, pl. 25, fig. 3c).

?1931. Acanthoscaphites nodosus var. quadrangularis (Meek and Hayden). Warren, pl. 1, fig. 2.

1934. Acanthoscaphites nodosus quadrangularis. Coryell and Salmon, fig. 9a, b (= Meek, 1876, pl. 25, fig. 3a, b).
1944. Acanthoscaphites nodosus quadrangularis.

Shimer and Shrock, p. 591, pl. 246, figs. 4-6 (= Meek, 1876, pl. 25, fig. 3a-c).

?1968. Scaphites elegans Tate. Jeletzky, p. 49.

1983. Jeletzkytes cf. brevis (Meek, 1876) o. Riccardi, p. 25 (pars), pl. 10, figs. 5, 6 only (= Meek, 1876: pl. 25, fig. 3a, b), ? figs. 10-18; ? text-fig. 22b (suture).

1997. Jeletzkytes "quadrangularis" (Meek and Hayden, 1860). Larson et al., p. 78, unnumbered fig., lower right (= Meek, 1876, pl. 25, fig. $3 a+$ ventral view).

non 2010. Hoploscaphites plenus (Meek, 1876). Landman et al., p. 14, fig. 6A-C (= Hoploscaphites crassus microconch).

2010. Hoploscaphites plenus (Meek, 1876), microconch. Landman et al., p. 14, fig. $6 \mathrm{H}-\mathrm{K}$ (= Meek, 1876, pl. 25, figs. 3a, b + right lateral + ventral).

Emended Diagnosis: Macroconchs medium to large in size, robust; whorl cross section of shaft depressed subquadrate with broadly rounded flanks and venter; width of venter approximately $70 \%$ whorl height; small umbilicus; apertural angle averaging $60^{\circ}$; long, fine, straight, closely spaced ribs on adoral part of phragmocone, with little branching or intercalation, and moderately strong adoral projection on venter; long, fine, straight, more widely spaced ribs on shaft, with moderately strong adoral projection on venter; small, closely spaced umbilicolateral tubercles on phragmocone, becoming slightly larger and more widely spaced on body chamber; small, moderately widely spaced ventrolateral tubercles on phragmocone at $7 / 8$ whorl height, becoming much larger and more widely spaced on body chamber, usually persisting to aperture. Microconchs medium to large in size, robust, and more loosely uncoiled than macroconchs; umbilical wall of shaft broad and outwardly sloping; pattern of ornament similar to that of macroconchs, with relatively more prominent umbilicolateral tubercles. Suture deeply incised with broadstemmed asymmetircally bifid first lateral saddle. 
Types: Meek and Hayden (1860a: 177) described Scaphites nodosus var. plenus and noted that

it differs from Dr. Owen's [1852] figure of S. nodosus in being greatly more ventricose, and shorter in proportion to its height, whilst the inner row of nodes are much smaller and near the umbilicus. There are some differences in the details of the septa which cannot, however, be readily explained without figures. It is likewise much larger than the specimens represented by Professor Owen, or any individual of that form that we have seen, its length being 4.57 inches, height 3.87 inches, and its breadth 2.52 inches.

The detailed dimensions given by the authors indicate that they were referring to a single specimen, which is, thus, the type by monotypy (USNM 364). Meek (1876: pl. 26, fig. 1a-c) illustrated "the perfect large type-specimen of this variety," which exactly matches the dimensions given by Meek and Hayden (1860a: 177). It is a steinkern of a macroconch but retains some shell on the adoral end of the phragmocone and body chamber. The right side of the hook exhibits a large reparied injury. It is from the Pierre Shale on the "Yellowstone River, Montana, 150 miles [248 km] above the mouth," and was collected by Lieutenant G.K. Warren of the U.S. Topographical Engineers. It is probably from the layer of scaphite concretions in the lower Baculites baculus Zone of the Pierre Shale on the Cedar Creek Anticline, Montana (Bishop, 1967, 1973). Since its initial description, the variety plenus has been elevated to the species level by many authors (e.g., Riccardi, 1983).

The holotype (USNM 366) of Scaphites nodosus var. quadrangularis illustrated by Meek (1876: 428, pl. 25, figs. 3a-c) is a microconch of Hoploscaphites plenus (fig. $56 \mathrm{H}-\mathrm{K}$ ). Together, with the macroconch described above, they form a single dimorphic pair, here desginated as $H$. plenus. The microconch is from the same locality as the macroconch. It is relatively finely ribbed with widely spaced ventrolateral tubercles. It exhibits a repaired injury on the venter at the point of recurvature, which takes the form of a blister and, as a result, the ribs are more widely spaced in this region.

Material: The collection consists of 85 complete or nearly complete specimens of which 38 macroconchs and 30 microconchs comprise the measured set. They are most abundant in the Baculites baculus Zone but occasionally occur in the $B$. eliasi Zone and possibly in the lower part of the B. grandis Zone.

Macroconch Description: Adults are medium to large in size. LMAX averages 96.0 $\mathrm{mm}$ and ranges from 71.8 to $130.7 \mathrm{~mm}$ (table $3)$. The holotype is on the larger end of the spectrum (LMAX = $116.2 \mathrm{~mm}$ ). As in Hoploscaphites crassus, the size distribution is broad with peaks at $85-90 \mathrm{~mm}$ and $95-100$ $\mathrm{mm}$. Many of the smaller specimens such as BHI 4303 (fig. 49) and BHI 4701 (fig. 50) appear to be from higher up in the stratigraphic section (upper part of the Baculites baculus Zone or possibly lower part of the B. grandis Zone), but the details needed to confirm this are lacking. The ratio of the size of the largest specimen to that of the smallest is 1.82 . The outline of the shell in lateral view is oval. $\mathrm{LMAX} / \mathrm{H}_{\mathrm{S}}$ averages 2.16 and ranges from 2.02 to 2.34 (2.23 in the holotype). YPM 35679 (fig. 53) is an example of a shell with a more rounded outline $\left(\mathrm{LMAX} / \mathrm{H}_{\mathrm{S}}\right.$ = 2.02) and AMNH 76294 (fig. 46) is an example of a shell with a more oval outline (LMAX/ $H_{S}=2.34$ ). The shells are relatively tightly coiled with a short shaft and small gap, if any, between the phragmocone and hook. LMAX/ $\mathrm{H}_{\mathrm{P} 2}$ averages 2.85 and ranges from 2.56 to 3.05 (2.95 in the holotype).

The phragmocone occupies approximately $1 / 2$ whorl and usually terminates just below the line of maximum length. The apertural angle averages $60^{\circ}$ and ranges from $44^{\circ}$ to $73^{\circ}$ (table 3 ). The apertural margin is flexuous with a prominent constriction and accompanying varix. The umbilicus is small and deep. The umbilical diameter averages $5.1 \mathrm{~mm}$, and ranges from 3.7 to $6.9 \mathrm{~mm}$. UD/LMAX averages 0.05 and ranges from 0.04 to 0.07 (table 3 ). The umbilical shoulder of the shaft is straight in side view with a weak umbilical bulge. 
The whorl section of the phragmocone at the point of exposure is depressed subquadrate with maximum whorl width at $1 / 3$ whorl height. $\mathrm{W}_{\mathrm{P} 1} /$ $\mathrm{H}_{\mathrm{P} 1}$ averages 1.10 and ranges from 0.90 to 1.24 (1.23 in the holotype). The umbilical wall is steep and subvertical and the umbilical shoulder is sharply rounded. The flanks are broadly rounded and gently converge toward the venter. The ventrolateral shoulder is sharply rounded and the venter is broadly rounded. In passing from the adapical to the adoral end of the phragmocone, both the whorl width and whorl height increase equally, so that the cross section of the shell, as viewed from the ventral side, does not develop a V-shape, as in Hoploscaphites crassus. The whorl section of the phragmocone along the line of maximum length is only slightly more depressed than that at the point of exposure. $\mathrm{W}_{\mathrm{P} 2} / \mathrm{H}_{\mathrm{P} 2}$ averages 1.17 and ranges from 0.99 to 1.31 (1.22 in the holotype).

The shell attains its maximum whorl width on the adoral one-third of the shaft, after which the width decreases steadily to the aperture. The shell attains its maximum whorl height at midshaft, after which the height decreases to the point of recurvature and then remains nearly the same up to the aperture. The whorl section at midshaft is depressed subquadrate to reniform. For example, it is subquadrate in YPM 35679 (fig. 53) whereas it is more nearly reniform in the holotype (fig. 42). $\mathrm{W}_{\mathrm{S}} / \mathrm{H}_{\mathrm{S}}$ averages 1.09 and ranges from 0.97 to 1.28 (1.20 in the holotype). The umbilical wall of the shaft is steep and subvertical and the umbilical shoulder is sharply rounded. The inner flanks are inflated and well rounded and the outer flanks are more broadly rounded and gently converge toward the venter. The ventrolateral shoulder is sharply rounded and the venter is broadly rounded. $\mathrm{V}_{\mathrm{S}} / \mathrm{H}_{\mathrm{S}}$ averages 0.68 and ranges from 0.52 to 0.87 (0.83 in the holotype), indicating that, on average, the venter is not as wide as the whorl is high.

The whorl section becomes more depressed toward the point of recurvature due to a marked decrease in whorl height. $\mathrm{W}_{\mathrm{H}} / \mathrm{H}_{\mathrm{H}}$ averages 1.24 and ranges from 1.05 to 1.43 (1.25 in the holo- type). The umbilical shoulder is sharply rounded and the flanks are well rounded. The venter is much narrower and more sharply rounded than at midshaft. As in Hoploscaphites crassus, the apertural opening is reduced in size relative to the whorl section at midshaft. It is depressed trigonal in AMNH 76294 (fig. 46) and depressed subovoid in SDSM 149981 (fig. 43).

At the point of exposure, strong ribs arise at the umbilical seam and cross the umbilical wall slightly rursiradiate. They strengthen on the umbilical shoulder and bend slightly backward on the inner flanks and intersect the umbilicolateral tubercles. One rib usually joins an umbilicolateral tubercle dorsally and two or three ribs branch from it ventrally, with one rib intercalating between tubercles. The ribs are straight, moderately widely spaced, and prorsiradiate on the outer flanks with additional intercalation and branching at the ventrolateral tubercles and on the outer margins of the outer flanks. One rib usually joins a ventrolateral tubercle dorsally and two or three ribs branch from it ventrally, with two or three ribs intercalating between tubercles. If the ventrolateral tubercles are paired on opposite sides of the venter, ribs that branch from a tubercle on one side of the venter loop to a tubercle on the opposite side. Ribs are uniformly strong and evenly spaced on the venter, which they cross with a moderately strong adoral projection. In the holotype, the rib density on the venter is $6 \mathrm{ribs} / \mathrm{cm}$ on the adapical end of the phragmocone.

On the adoral end of the phragmocone, ribs are narrow and slightly rursiradiate on the umbilical wall. They strengthen on the inner flanks and pass between or merge with the umbilicolateral tubercles. In the holotype, one or two ribs join an umbilicolateral tubercle dorsally and two or three ribs branch from it ventrally, with one or two ribs intercalating between tubercles. The outer flanks are covered with long, narrow, closely spaced, rectiradiate ribs, a pattern that this species shares in common with Hoploscaphites crassus and $H$. peterseni. Intercalation and branching occur on the outer margins 
of the outer flanks and at the ventrolateral tubercles. In the holotype, groups of four or five ribs branch from each ventrolateral tubercle and link to tubercles on the opposite side of the venter, with as many as five nontuberculate ribs intercalating between tubercles. Ribs cross the venter with a moderately strong adoral projection. The rib density on the venter on the adoral part of the phragmocone ranges from 6 to $8 \mathrm{ribs} / \mathrm{cm}$ ( $6 \mathrm{ribs} / \mathrm{cm}$ in the holotype).

On the shaft, ribs cross the umbilical wall with a slight backward bend. In YPM 35679 (fig. 53), $9 \mathrm{ribs} / \mathrm{cm}$ are present on the umbilical wall. They strengthen on the umbilical shoulder and are concave on the inner flanks. Due to poor preservation of this specimen, it is difficult to determine the exact number of ribs that join and branch from each umbilicolateral tubercle. The best estimate is that one or two ribs join an umbilicolateral tubercle dorsally and two or three ribs branch from it ventrally. Ribs are straight and weakly prorsiradiate on the flanks, becoming more strongly prorsiradiate adorally. In the holotype, four or five ribs join a ventrolateral tubercle dorsally and six or seven ribs branch from it ventrally, with as many as eight ribs intercalating between tubercles. Because tubercles are offset on opposite sides of the venter in the holotype, the ribs that branch from a tubercle on one side of the venter intercalate between pairs of tubercles on the opposite side of the venter. Ribs cross the venter with a moderately strong adoral projection. The rib density on the venter ranges from 5 to $8 \mathrm{ribs} / \mathrm{cm}$ (6 ribs/cm in the holotype).

As on the shaft, the ribs on the flanks of the hook are straight and prorsiradiate. The ribbing on the holotype is interrupted by an injury on the right side (fig. 42). As a result, the ribs are strongly convex on the flanks and bend backward at the ventrolateral margin, which is devoid of ornament. In contrast, the ornament on the left side of the shell is undisturbed. In all specimens, ribs cross the venter with a moderately strong adoral projection. In general, the ribs on the hook are slightly more closely spaced than those on the shaft ( $6 \mathrm{ribs} / \mathrm{cm}$ on the venter of the shaft versus $7 \mathrm{ribs} / \mathrm{cm}$ on the venter of the hook in the holotype).

Small, closely spaced umbilicolateral tubercles are present on the phragmocone in most, but not all, specimens. They occur at $1 / 3$ whorl height. The tubercles are more or less evenly spaced, becoming slightly more widely spaced toward the adoral end of the phragmocone. The maximum distance between consecutive tubercles ranges from 4 to $5.5 \mathrm{~mm}$ ( $4.5 \mathrm{~mm}$ in the holotype). A total of 11 umbilicolateral tubercles are present on the phragmocone of the holotype. The tubercles are bullate in shape and radially elongate, with a maximum height of $1 \mathrm{~mm}$.

If umbilicolateral tubercles are present on the phragmocone, they usually extend onto the body chamber, but not necessarily to the aperture. They are surprisingly weak relative to the much stronger ventrolateral tubercles. They occur at $1 / 3$ whorl height and become more widely spaced adorally, with the maximum distance between consecutive tubercles ranging from 10 to $17 \mathrm{~mm}$ (17 $\mathrm{mm}$ in the holotype). A total of 4 umbilicolateral tubercles are present on the body chamber of the holotype, so that the total number of umbilicolateral tubercles on the exposed shell of this specimen is 14 . The tubercles are bullate in shape with a maximum height of $2 \mathrm{~mm}$.

Ventrolateral tubercles are present at the point of exposure and continue onto the entire exposed phragmocone. They occur at $7 / 8$ whorl height and are perched either on the ribs or in the interspaces between them. Tubercles may be paired or offset from one side of the venter to the other. A total of 11 ventrolateral tubercles are present on the phragmocone of the holotype. Tubercles are more or less evenly spaced, becoming more widely spaced toward the base of the body chamber. The distance between the two most adoral tubercles in the holotype is $13 \mathrm{~mm}$. Tubercles are conical in shape and slightly elongated radially. They range in height from $1.25-2.25 \mathrm{~mm}$.

The ventrolateral tubercles on the body chamber also occur at $7 / 8$ whorl height and are paired 
or offset on opposite sides of the venter. They are widely spaced with the maximum distance between consecutive tubercles occuring on the adoral end of the shaft, after which they become slightly more closely spaced on the hook and usually, but not always, persist to the aperture. We describe the spacing of tubercles in three specimens to illustrate the range of variation. In the holotype (fig. 42), the distance between tubercles increases from $19 \mathrm{~mm}$ on the adapical end of the shaft to $30 \mathrm{~mm}$ on the adoral end of the shaft, and then decreases to $25 \mathrm{~mm}$ on the hook. In AMNH 76294 (fig. 46), which is a slightly smaller specimen, the distance between tubercles on the shaft remains nearly the same throughout (14-16 $\mathrm{mm}$ ), and then gradually decreases to $8.5 \mathrm{~mm}$ near the aperture. In $\mathrm{AMNH}$ 135090 (fig. 47), which is nearly the same size as AMNH 76294, the distance between tubercles on the shaft also remains nearly the same throughout (17-20 $\mathrm{mm}$ ), and then gradually decreases to $7 \mathrm{~mm}$ near the aperture.

In addition to their wide spacing, one of the characteristic features of the ventrolateral tubercles is their large size. They reach a maximum size on the adoral end of the shaft and beginning of the hook, after which they diminish in size or disappear. They are clavate in shape with steeply sloping adapical faces and gently sloping adoral faces. Where preserved in their entirety, or nearly so, tubercles range from 2 to 6 $\mathrm{mm}$ in height and up to $11 \mathrm{~mm}$ in length. Commonly, however, the tubercles are broken off and only their bases remain.

As a result of their large size and wide spacing, the number of ventrolateral tubercles on the shell is lower than that in the closely related species Hoploscaphites crassus. For example, the total number of ventrolateral tubercles on the exposed shell of the holotype of H. plenus is 19 (fig. 42). The total number of tubercles on the exposed shell of BHI 4701 is 18 (fig. 50) and the total number of tubercles on the exposed shell of $\mathrm{AMNH}$ 105910 is 23 (fig. 44). In contrast, the total number of ventrolateral tubercles on the exposed shell of the holotype of $H$. crassus is 30 (fig. 13).
Lateral tubercles are rare or absent in all of the specimens in our collection. The holotype bears slightly bullate swellings, three in number, starting at the point of exposure, on the left side of the shell. They occur near the ventrolateral tubercles on the outer one-third of the flanks. The maximum height of the swellings is $0.5 \mathrm{~mm}$ and the maximum distance between them is 6.5 $\mathrm{mm}$. The swellings disappear toward the middle one-third of the exposed phragmocone.

The suture is deeply incised (fig. 32C; Meek, 1876: pl. 26, fig. 1c; Elias, 1933: pl. 40, fig. 6). The first lateral saddle is broad stemmed and asymmetrically bifid. The first lateral lobe $(\mathrm{L})$ is narrow, symmetrically bifid, and not as deep as the ventral lobe.

Microconch Description: What we interpret as microconchs of this species are robust, loosely uncoiled forms, with relatively flat flanks and widely spaced ventrolateral tubercles on the body chamber. Adults are small to medium in size. LMAX averages $58.5 \mathrm{~mm}$ and ranges from 51.1 to $68.2 \mathrm{~mm}$ (table 4 ). The size distribution is unimodal with a peak at $60-65 \mathrm{~mm}$ (fig. 41). The ratio of the average size of microconchs to that of macroconchs is 0.61 .

UD averages $3.8 \mathrm{~mm}$ and ranges from 3.0 to $4.7 \mathrm{~mm}$ (table 4). UD/LMAX averages 0.06 and ranges from 0.06 to 0.08 . The average value in microconchs is higher than that in macroconchs (0.05). The umbilical shoulder is concave in lateral view in contrast to macroconchs in which it is straight or convex in lateral view. Microconchs are oval in side view and more loosely uncoiled than macroconchs. LMAX/H $\mathrm{H}_{\mathrm{P} 2}$ averages 3.02, which is significantly higher than that in macroconchs (2.85). The phragmocone is relatively large and represents approximately $60 \%$ of the shell length and usually terminates below the line of maximum length.

The whorl section at the point of exposure is subovoid and nearly equidimensional, with maximum whorl width at $1 / 4$ whorl height. $\mathrm{W}_{\mathrm{P} 1} / \mathrm{H}_{\mathrm{P} 1}$ averages 1.02 and ranges from 0.74 to 1.30 . The umbilical wall is steep and subvertical, and the umbilical shoulder is sharply rounded. The inner 


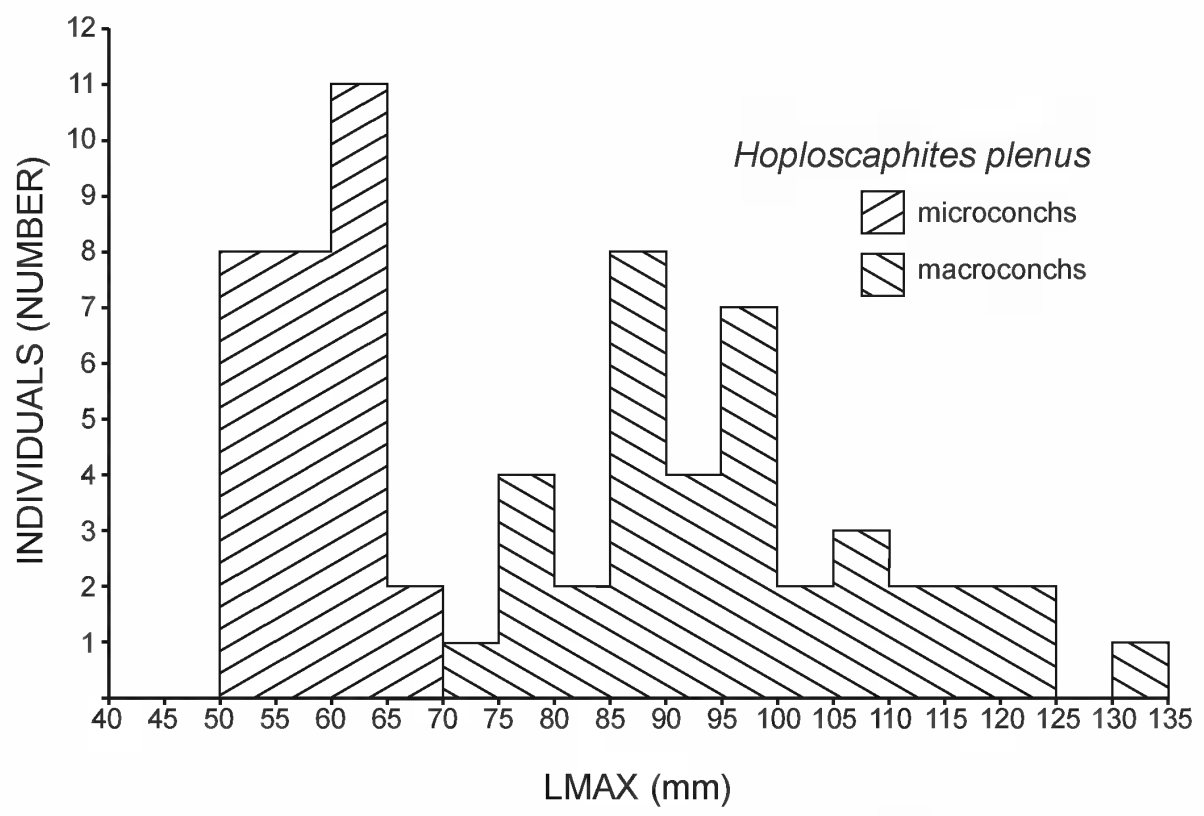

FIGURE 41. Size frequency histogram of Hoploscaphites plenus (Meek and Hayden, 1860), based on the samples in tables 3 and 4 .

flanks are well rounded and the outer flanks are broadly rounded and gently converge toward the venter. The ventrolateral shoulder is sharply rounded and the venter is broadly rounded.

Whorl width expands into the body chamber and attains its maximum value at the point of recurvature. Whorl height also increases, and attains its maximum value at midshaft, after which it remains the same. The whorl section at midshaft is depressed reniform with maximum whorl width at $1 / 3$ whorl height. $\mathrm{W}_{\mathrm{S}} / \mathrm{H}_{\mathrm{S}}$ averages 1.11 and ranges from 0.88 to 1.30 (table 4 ). The umbilical wall is broad and slopes outward, and the umbilical shoulder is sharply rounded. The inner flanks are well rounded and the outer flanks are broadly rounded. The ventrolateral shoulder is sharply rounded and the venter is broadly rounded. $\mathrm{V}_{\mathrm{S}} / \mathrm{H}_{\mathrm{S}}$ averages 0.74 and ranges from 0.59 to 0.90 , indicating that, on average, the venter is approximately $3 / 4$ as wide as the whorl is high. The whorl section at the point of recurvature is more ovoid and depressed than that at midshaft. $\mathrm{W}_{\mathrm{H}} / \mathrm{H}_{\mathrm{H}}$ averages 1.19 and ranges from 1.02 to 1.36 . The apertural opening is approxi- mately the same size as the whorl section at midshaft, unlike the situation in macroconchs in which the apertural opening is reduced relative to that at midshaft.

The ornament in microconchs is similar to that in macroconchs. On the exposed phragmocone, ribs arise at the umbilical seam and are strong and rectiradiate on the umbilical wall. They swing backward on the inner flanks, forward on the midflanks, and backward again on the outer flanks. Intercalation and branching occur almost exclusively at the umbilicolateral and ventrolateral tubercles. One rib usually joins an umbilicolateral tubercle dorsally and two ribs branch from it ventrally, with one rib intercalating between tubercles. One or two ribs join a ventrolateral tubercle dorsally and as many as four ribs branch from it ventrally, with one or two ribs intercalating between tubercles. Ribs are strong and uniformly spaced on the venter, which they cross with a moderately strong adoral projection. The rib density on the adoral part of the phragmocone is 8 or $9 \mathrm{ribs} / \mathrm{cm}$. 


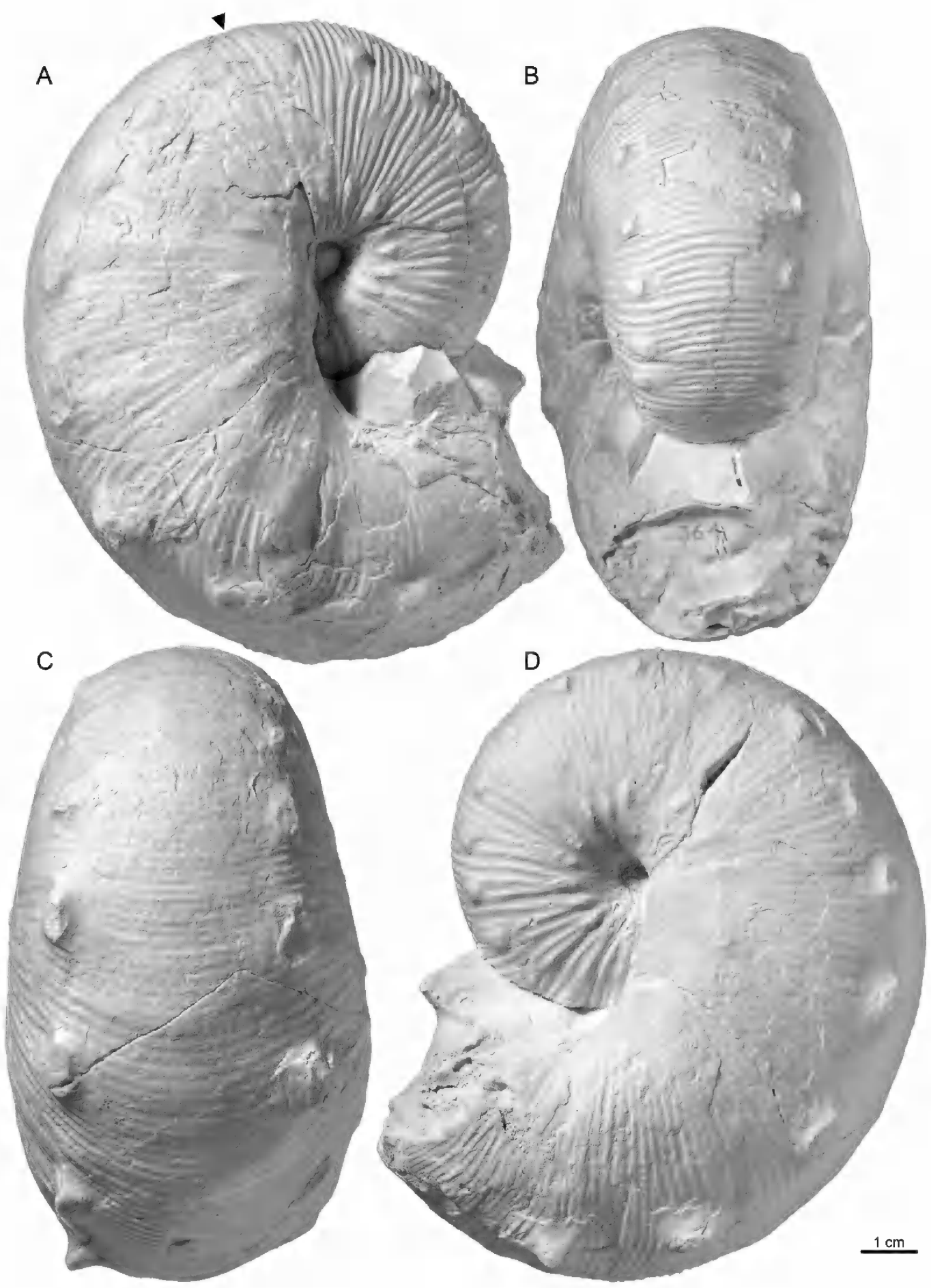

FIGURE 42. Hoploscaphites plenus (Meek and Hayden, 1860), macroconch. A-D. USNM 364, cast of holotype, unknown locality, but probably Baculites baculus or lower B. grandis Zone, Pierre Shale, Cedar Creek Anticline, east-central Montana. A, Right lateral; B, apertural; C, ventral; D, left lateral. Arrow indicates the base of the body chamber. 

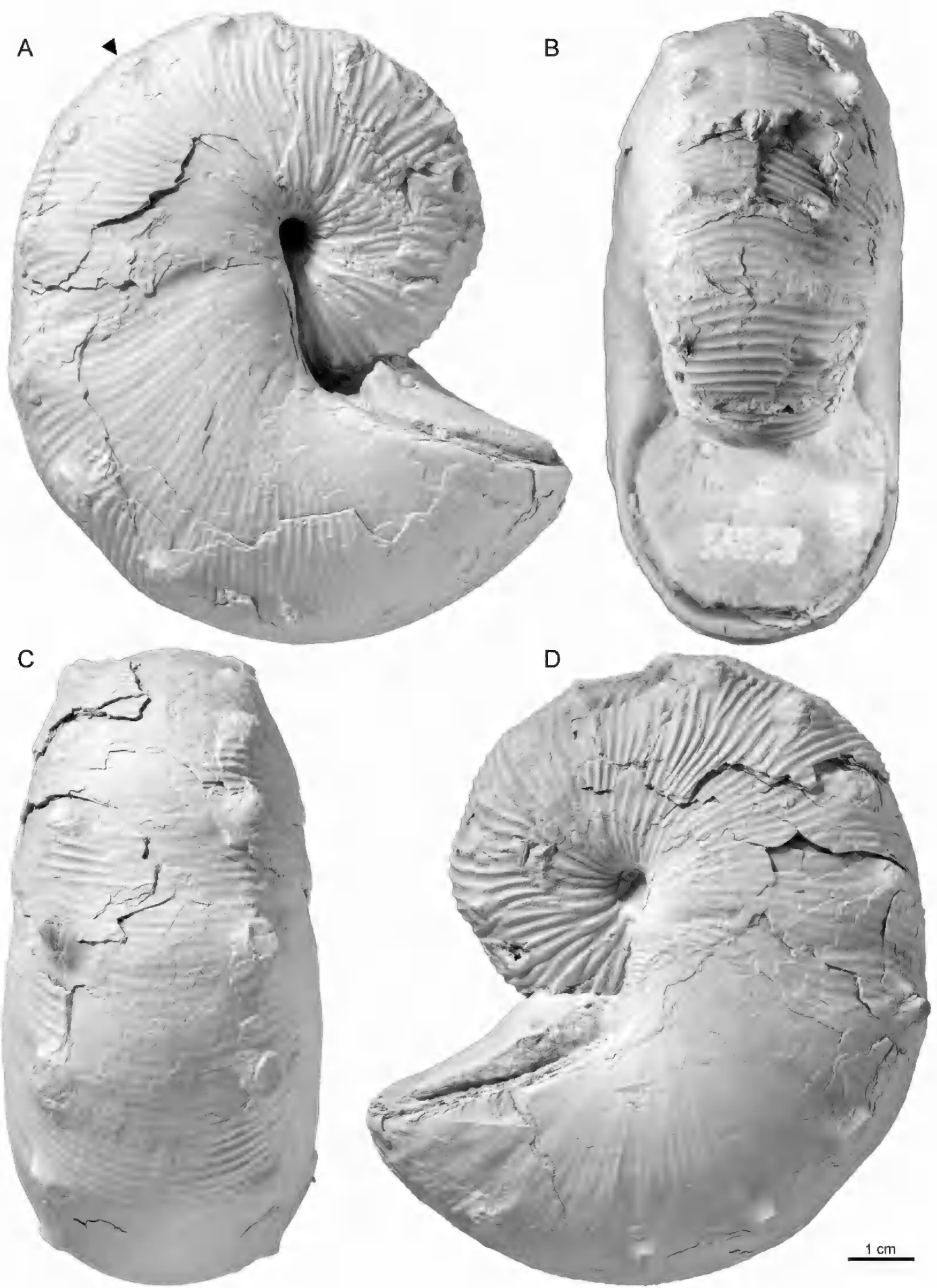

FIGURE 43. Hoploscaphites plenus (Meek and Hayden, 1860), macroconch. A-D. SDSM 149981, upper Baculites eliasi or lower B. baculus Zone, Pierre Shale, Dawson County, Montana. A, Right lateral; B, apertural; C, ventral; $\mathbf{D}$, left lateral. Arrow indicates the base of the body chamber. 


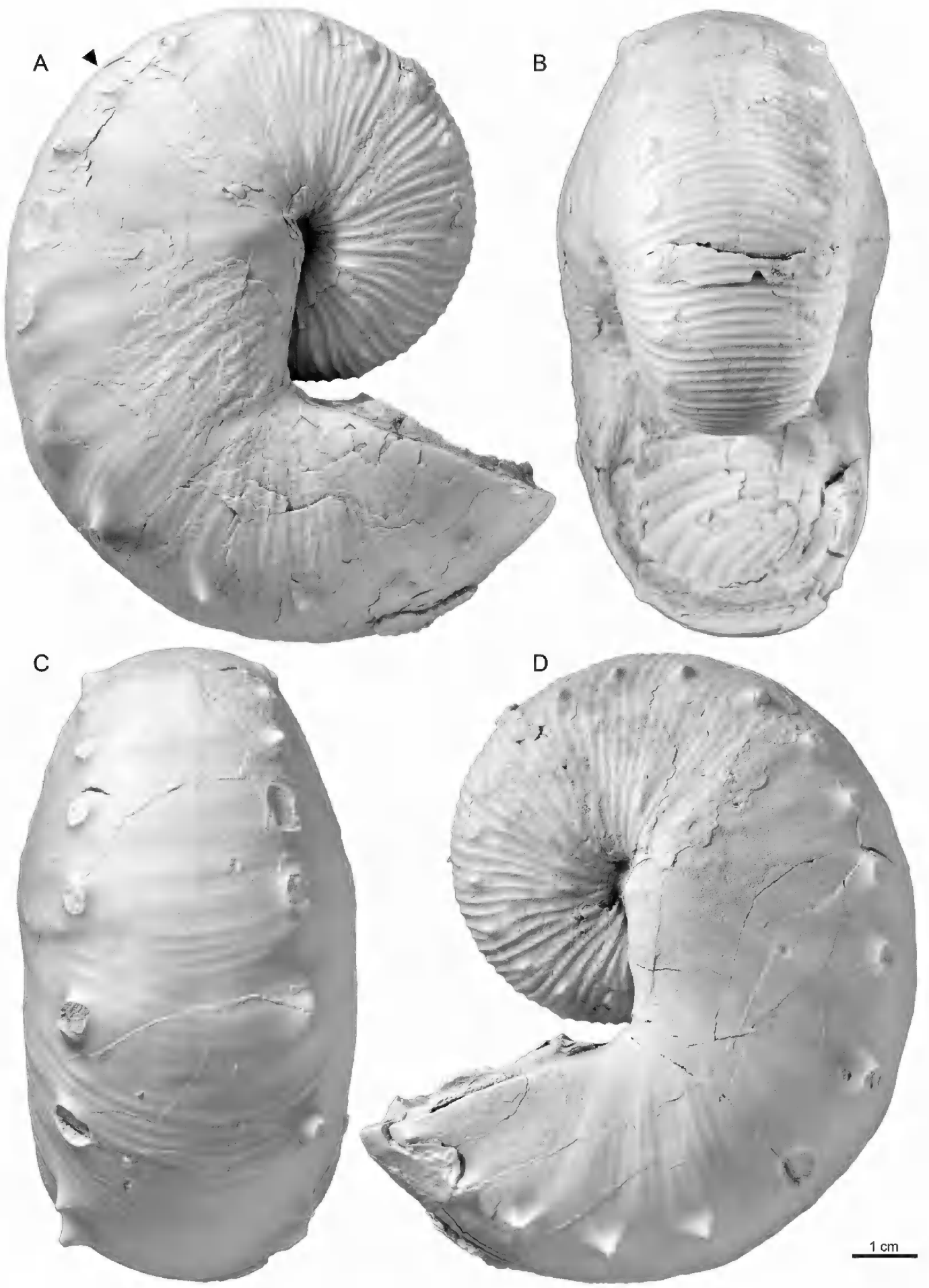

FIGURE 44. Hoploscaphites plenus (Meek and Hayden, 1860), macroconch. A-D. AMNH 105910, AMNH loc. 3921, upper Baculites baculus Zone, Pierre Shale, Cedar Creek Anticline, east-central Montana. A, Right lateral; B, apertural; C, ventral; D, left lateral. Arrow indicates the base of the body chamber. 

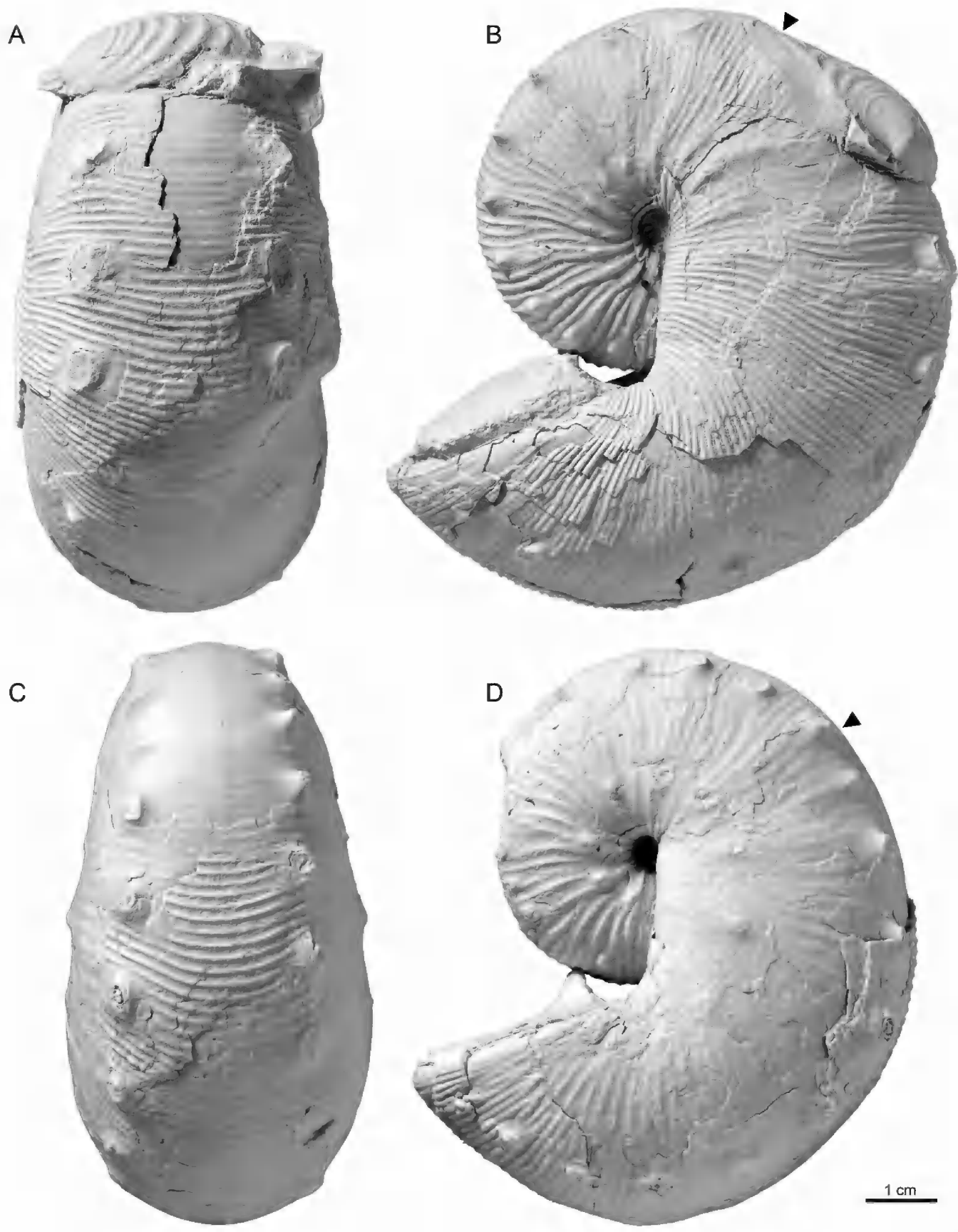

FIGURE 45. Hoploscaphites plenus (Meek and Hayden, 1860), macroconch. A, B. AMNH 135966, AMNH loc. 3921, lower Baculites baculus Zone, Pierre Shale, Cedar Creek Anticline, east-central Montana. A, ventral; B, left lateral. C, D. BHI 4130, Baculites baculus or B. grandis Zone, Pierre Shale, Cedar Creek Anticline, eastcentral Montana. C, ventral; D, left lateral. 


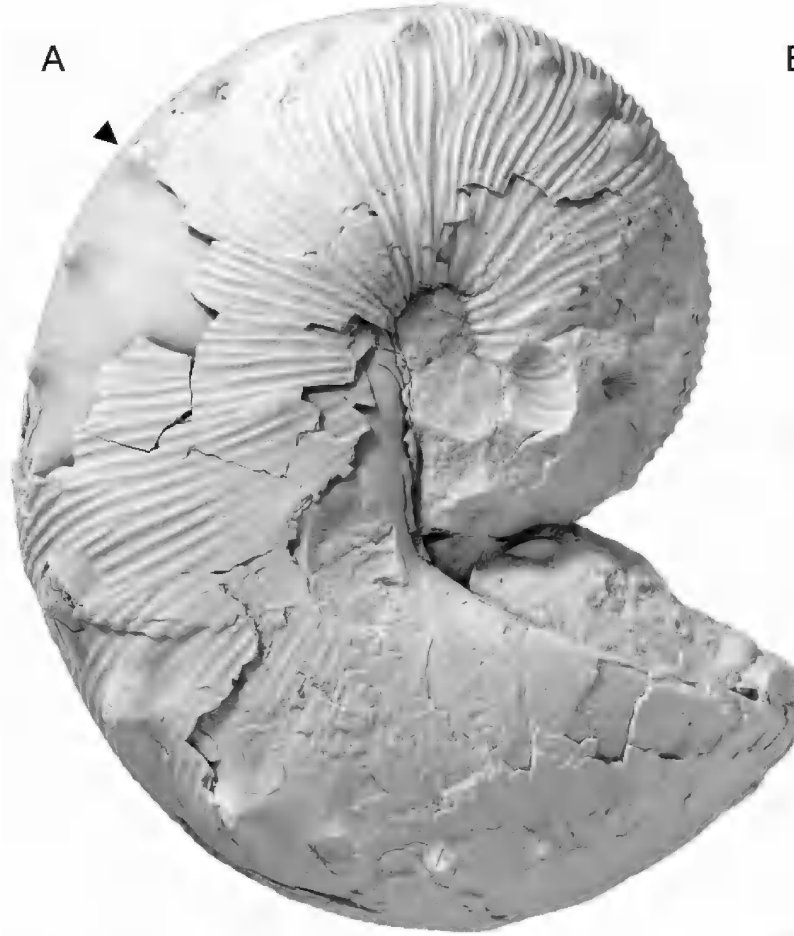

B

C
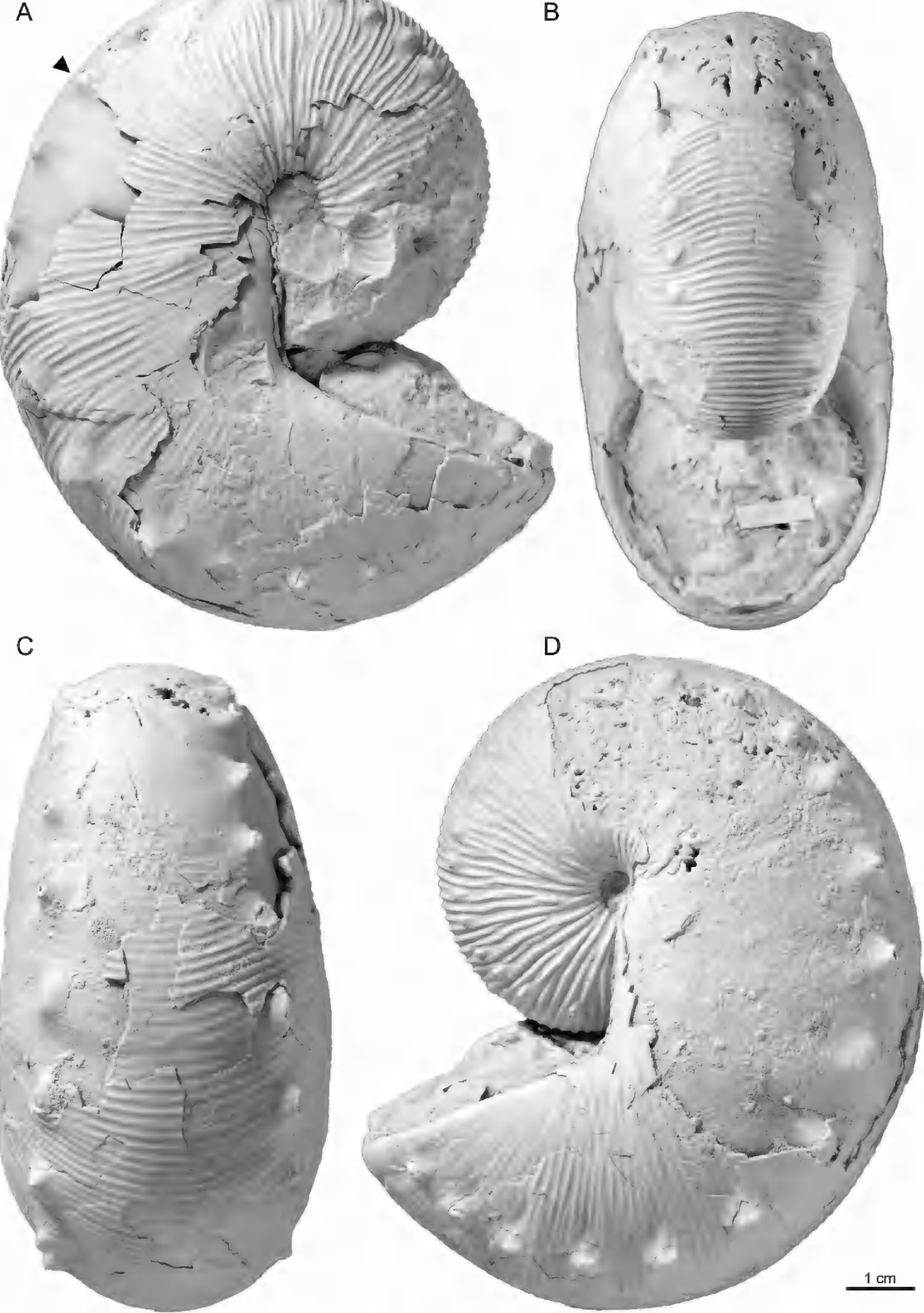

FIGURE 46. Hoploscaphites plenus (Meek and Hayden, 1860), macroconch. A-D. AMNH 76294, loc. 3921, upper Baculites baculus Zone, Pierre Shale, Cedar Creek Anticline, east-central Montana. A, Right lateral; B, apertural; C, ventral; D, left lateral. Arrow indicates the base of the body chamber. 


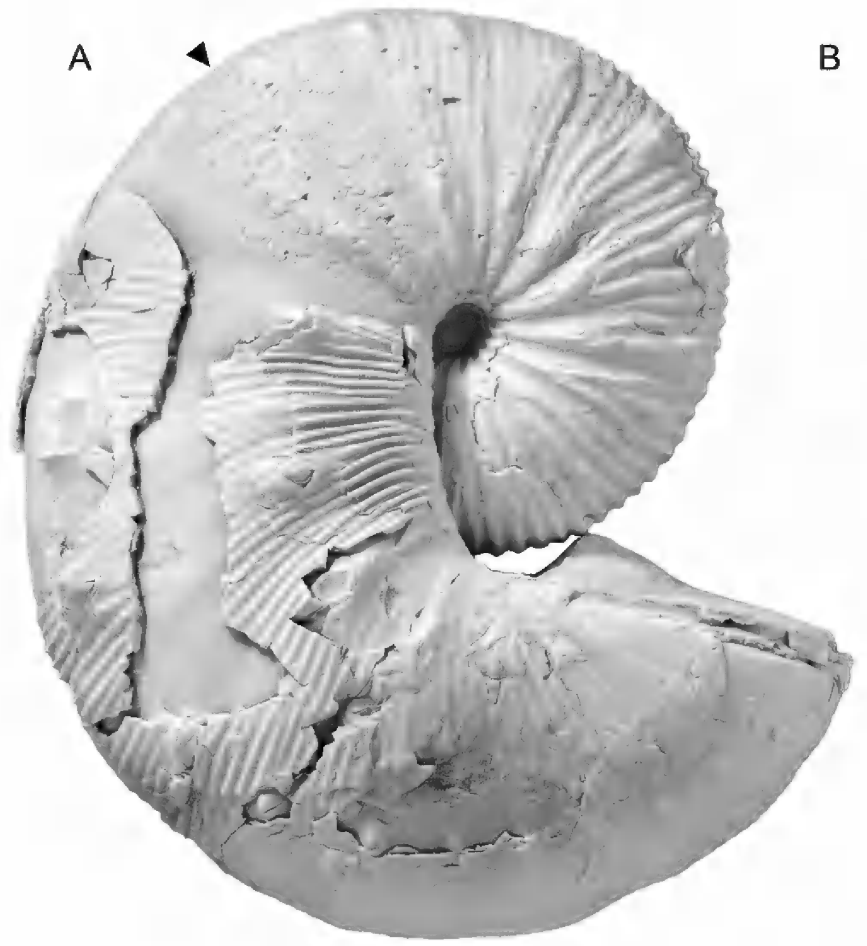

B
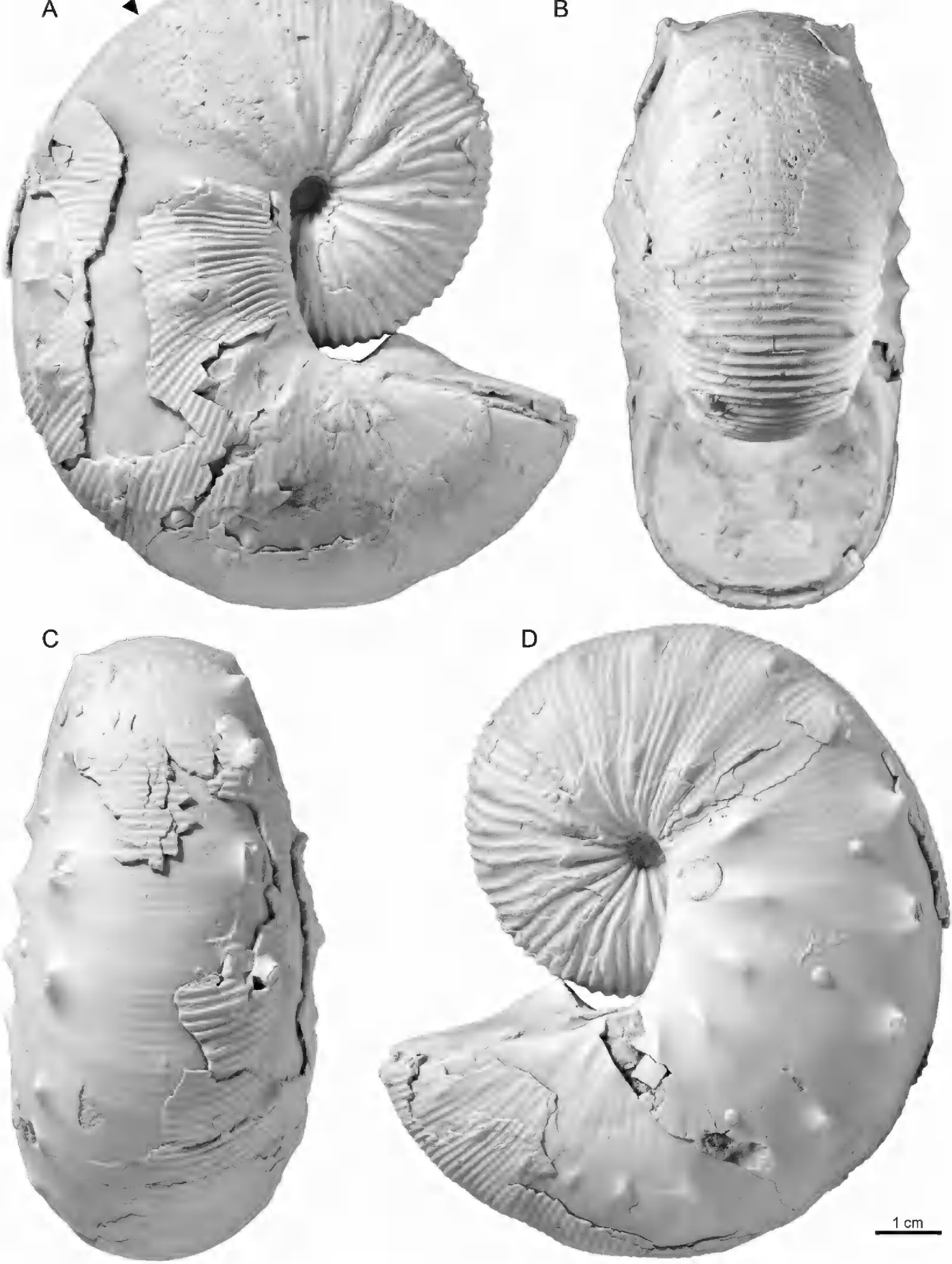

FIGURE 47. Hoploscaphites plenus (Meek and Hayden, 1860), macroconch. A-D. AMNH 135090, unknown locality. A, Right lateral; B, apertural; C, ventral; D, left lateral. Arrow indicates the base of the body chamber. 


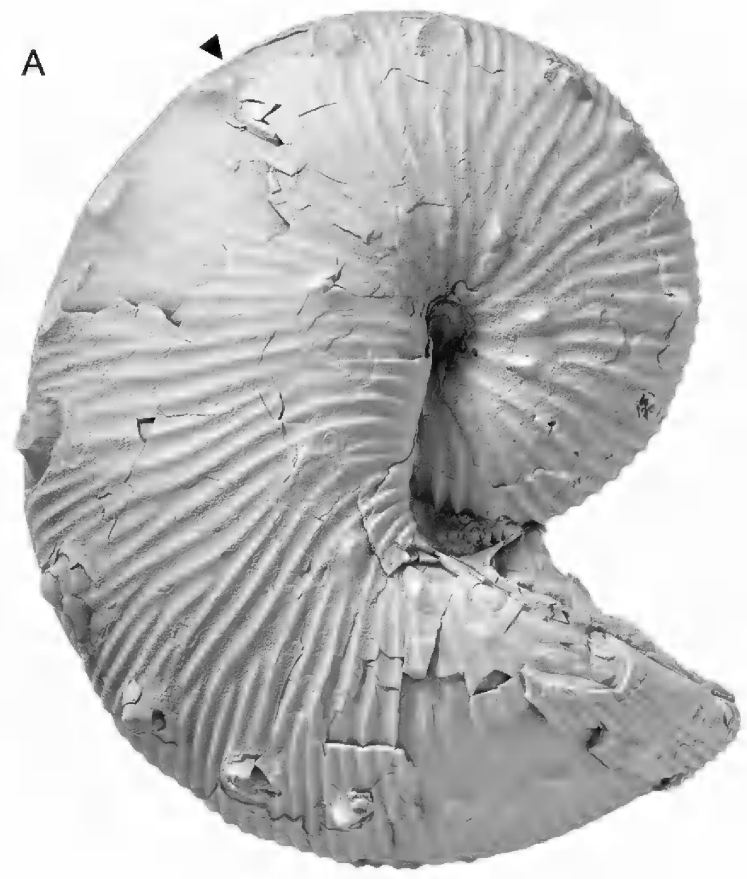

B
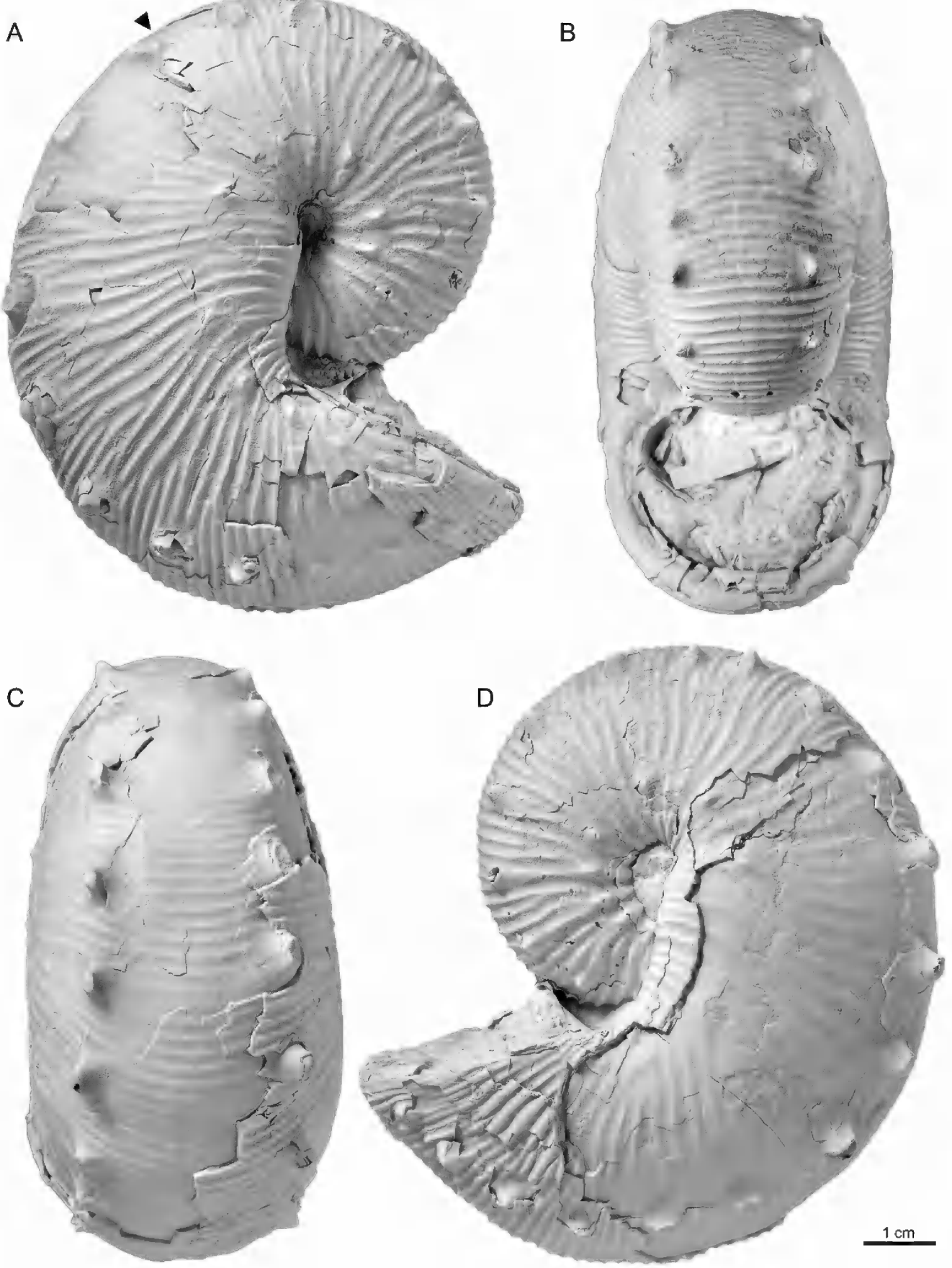

FIGURE 48. Hoploscaphites plenus (Meek and Hayden, 1860), macroconch. A-D. AMNH 71856, AMNH loc. 3921, upper Baculites baculus or lower B. grandis Zone, Pierre Shale, Cedar Creek Anticline, east-central Montana. A, Right lateral; B, apertural; C, ventral; D, left lateral. Arrow indicates the base of the body chamber. 


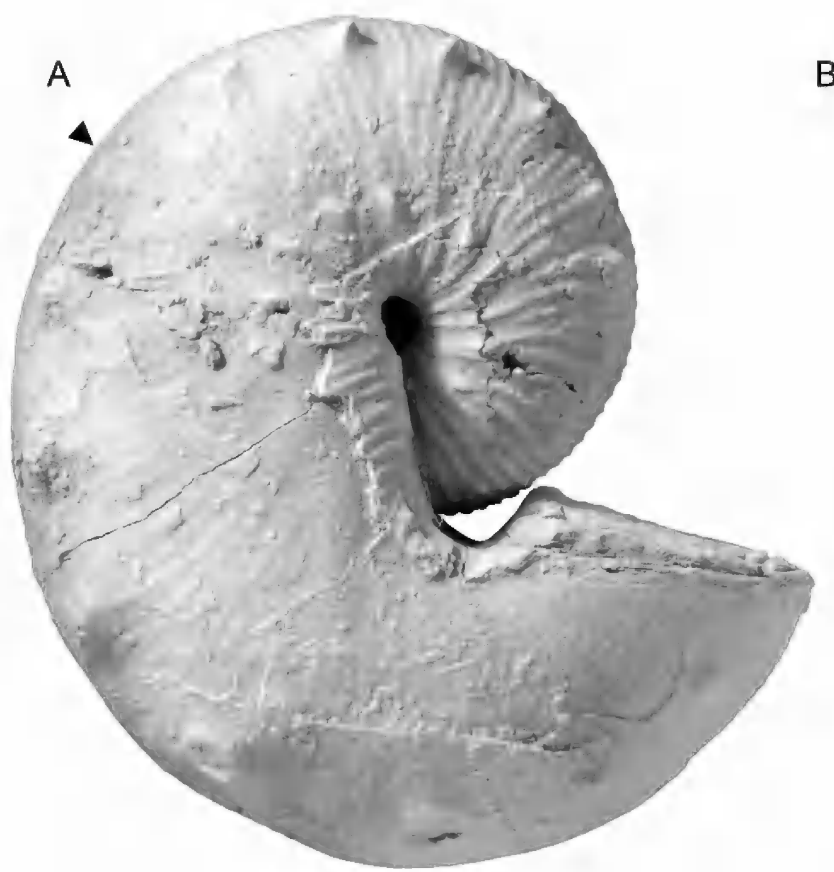

B
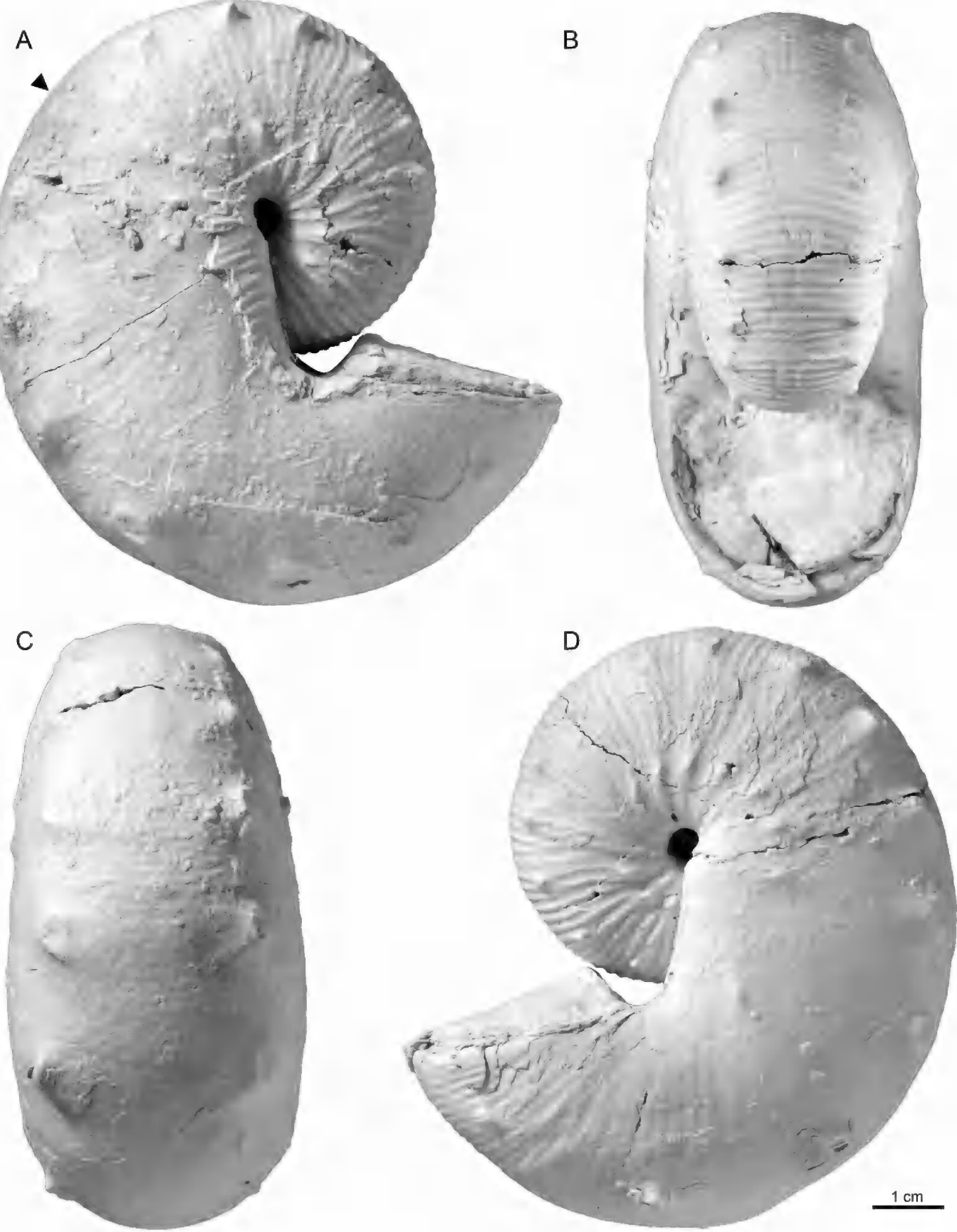

FIGURE 49. Hoploscaphites plenus (Meek and Hayden, 1860), macroconch. A-D. BHI 4303, Baculites baculus or lower B. grandis Zone, Pierre Shale, Cedar Creek Anticline, east-central Montana. A, Right lateral; B, apertural; C, ventral; D, left lateral. Arrow indicates the base of the body chamber. 

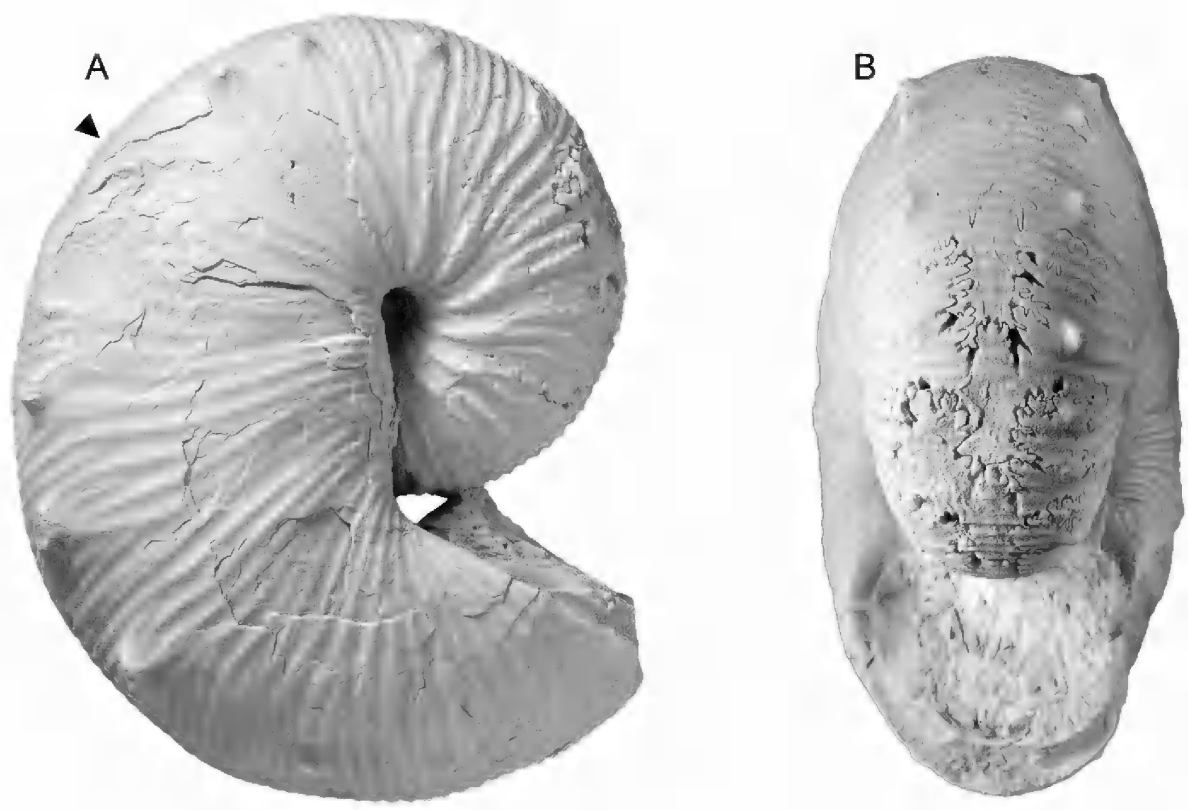

C
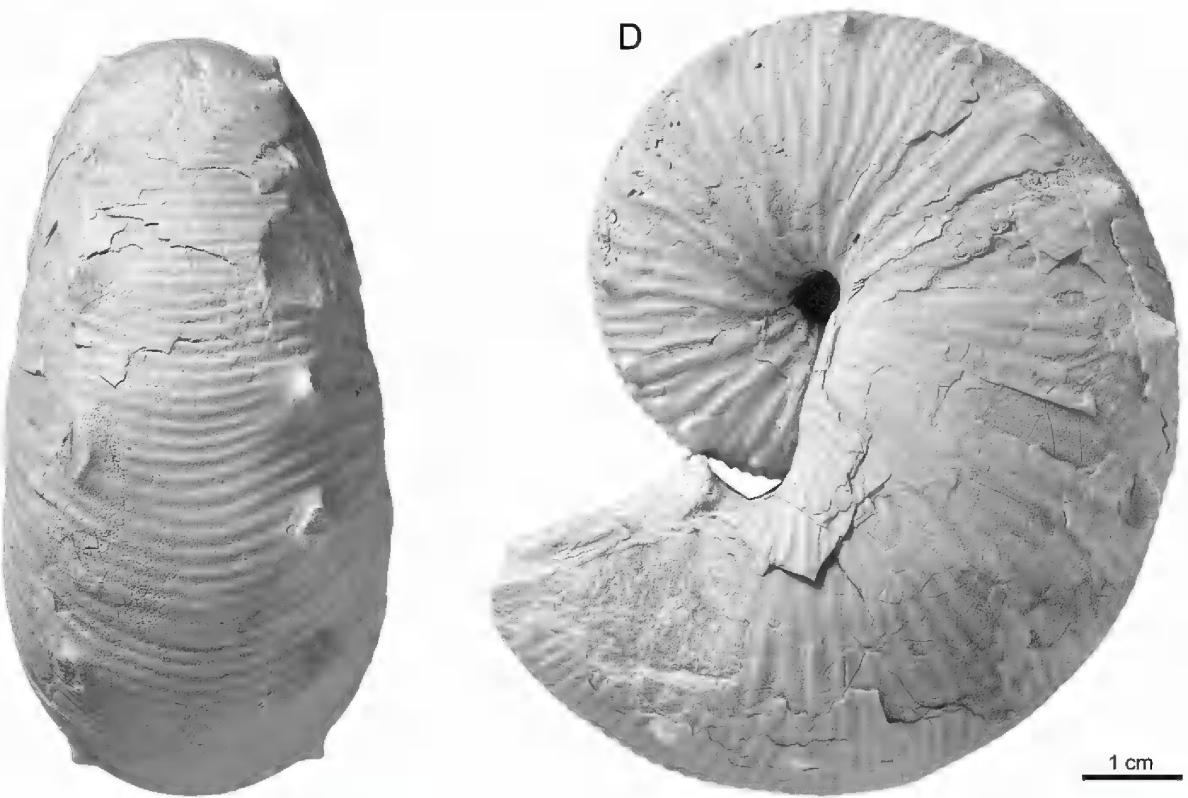

FIGURE 50. Hoploscaphites plenus (Meek and Hayden, 1860), macroconch. A-D. BHI 4701, Baculites baculus or lower B. grandis Zone, Pierre Shale, Cedar Creek Anticline, east-central Montana. A, Right lateral; B, apertural; C, ventral; D, left lateral. Arrow indicates the base of the body chamber. 

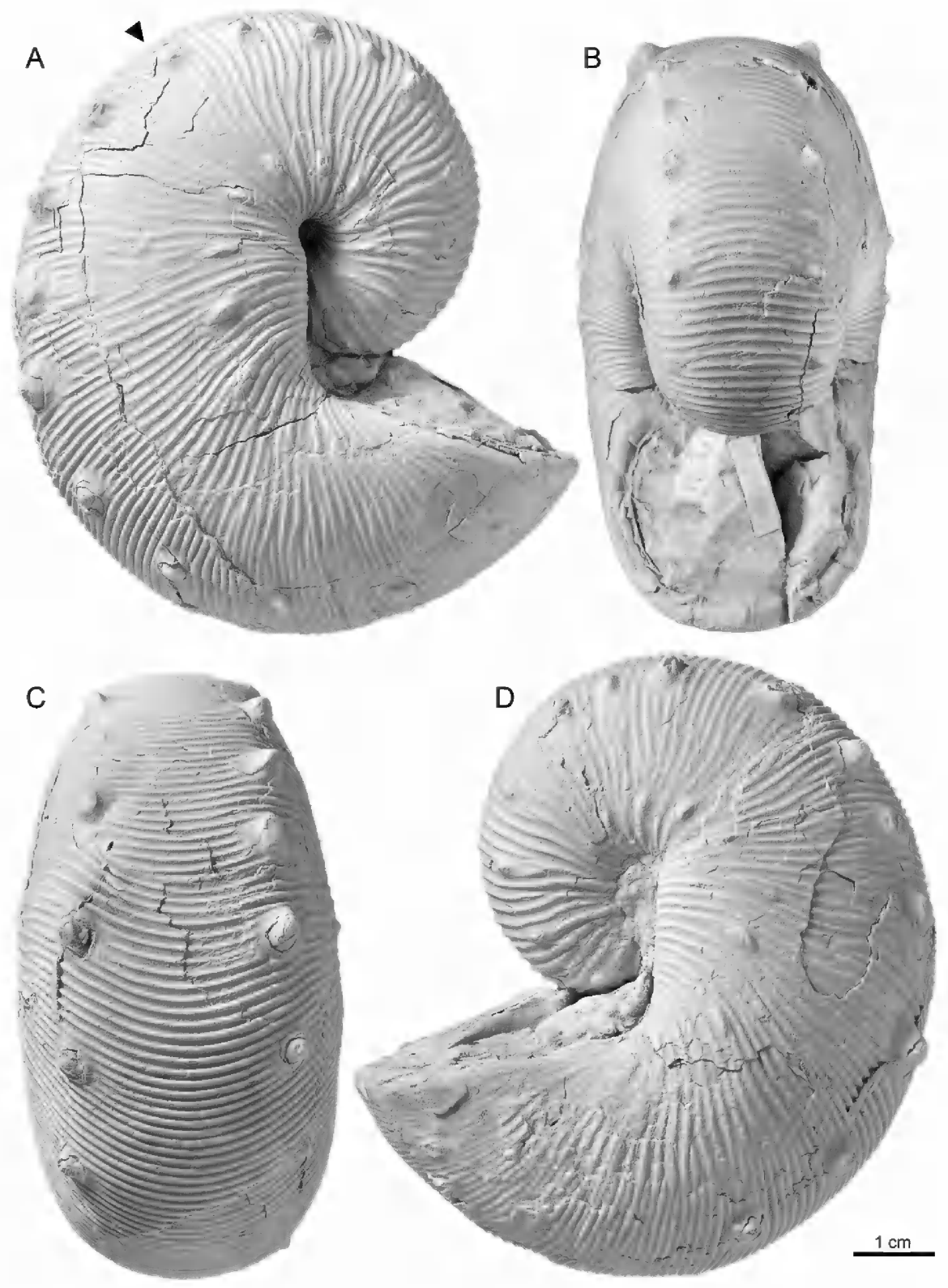

FIGURE 51. Hoploscaphites plenus (Meek and Hayden, 1860), macroconch. A-D. AMNH 76189, AMNH loc. 3921, Baculites baculus or lower B. grandis Zone, Pierre Shale, Cedar Creek Anticline, east-central Montana. A, Right lateral; B, apertural; C, ventral; D, left lateral. Arrow indicates the base of the body chamber. 
A

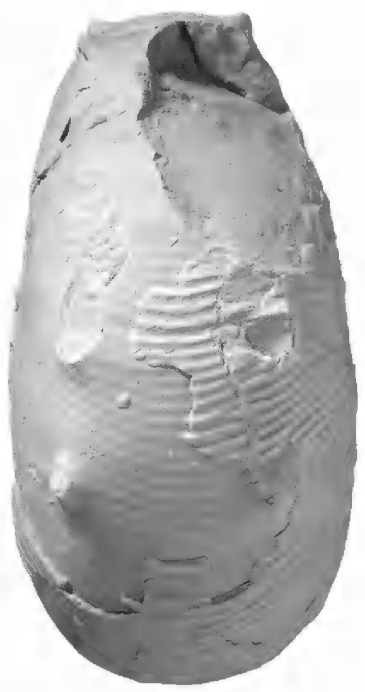

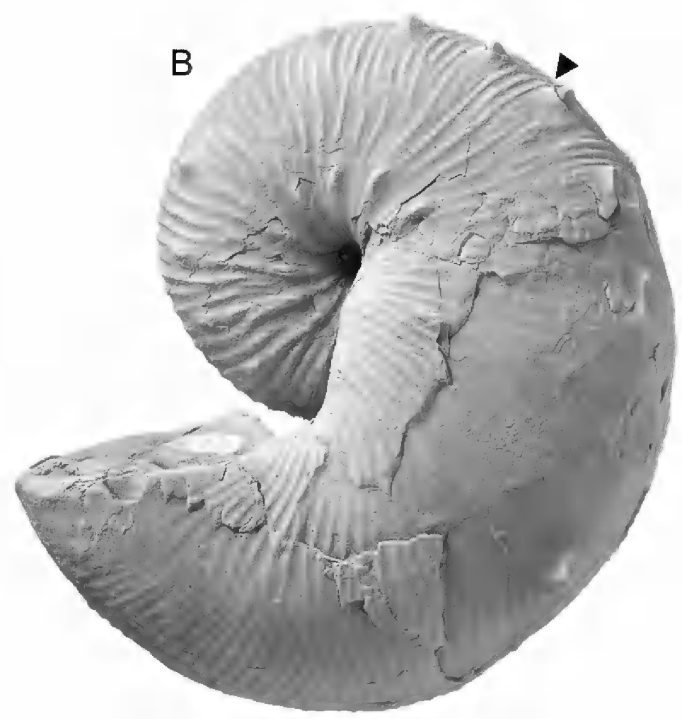
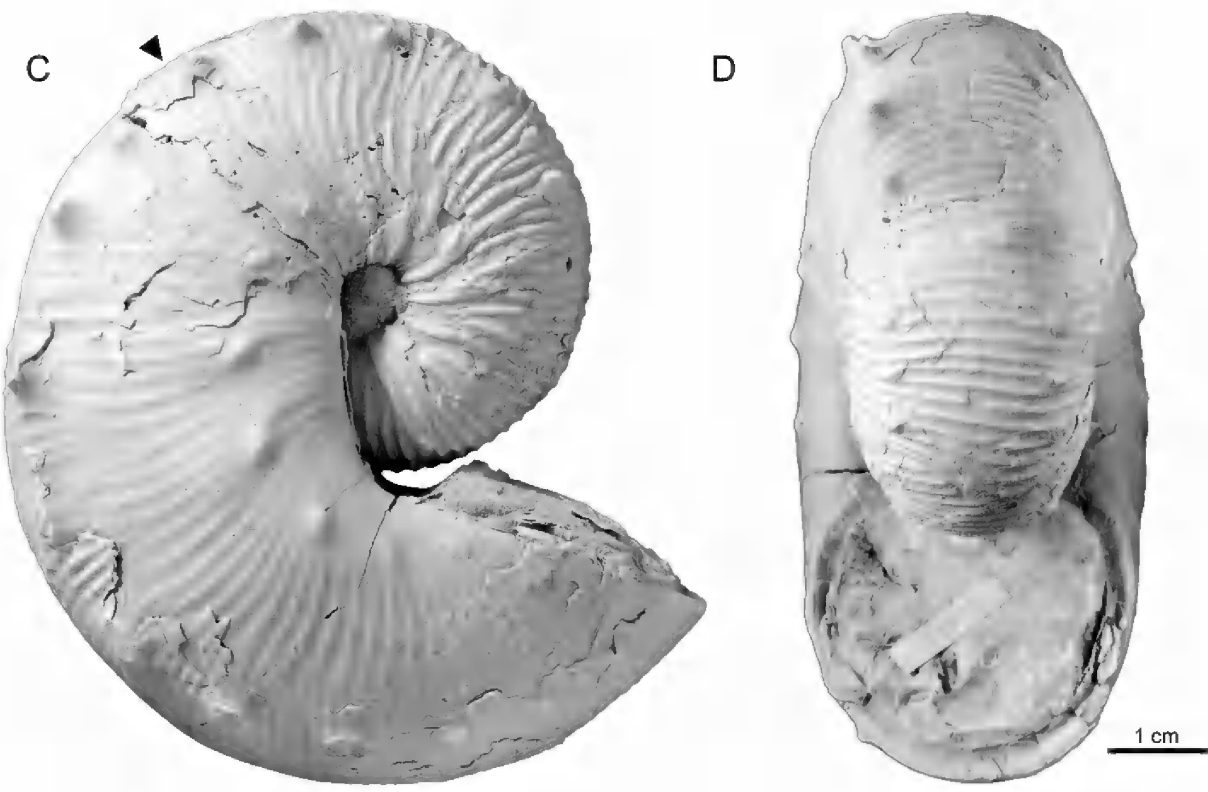

FIGURE 52. Hoploscaphites plenus (Meek and Hayden, 1860), small macroconchs. A, B. AMNH 71933, AMNH loc. 3921, Baculites baculus or lower B. grandis Zone, Pierre Shale, Cedar Creek Anticline, east-central Montana. A, ventral; B, left lateral. C, D. AMNH 71911, AMNH loc. 3921, upper Baculites baculus or lower B. grandis Zone, Pierre Shale, Cedar Creek Anticline, east-central Montana. C, left lateral; D, apertural. 


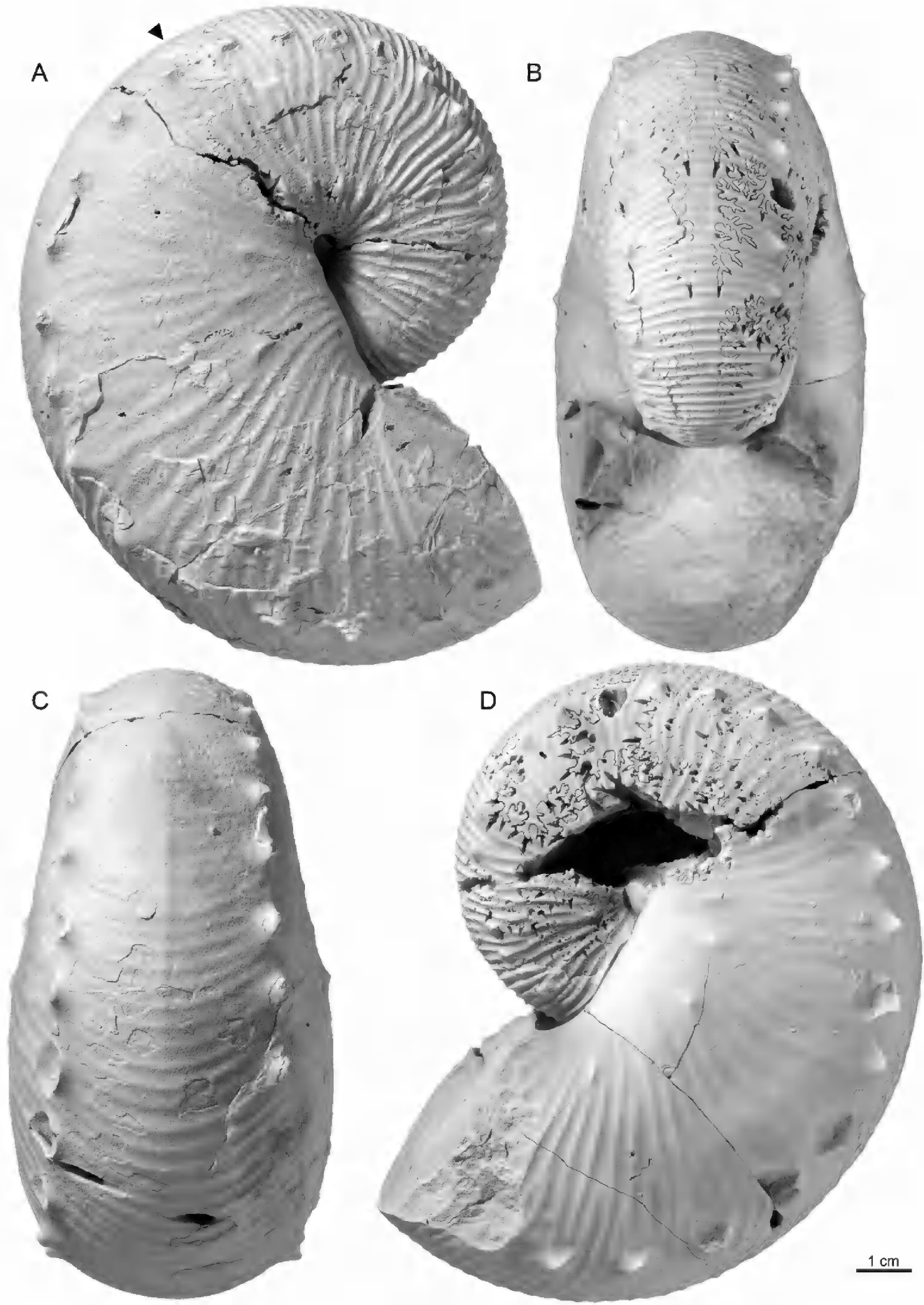

FIGURE 53. Hoploscaphites plenus (Meek and Hayden, 1860), large macroconch. A-D. YPM 35679, transitional to H. crassus (Coryell and Salmon, 1934), YPM loc. 4778, Baculites baculus Zone, Pierre Shale, Red Bird, Wyoming. A, Right lateral; B, apertural; C, ventral; D, left lateral. Arrow indicates the base of the body chamber. 

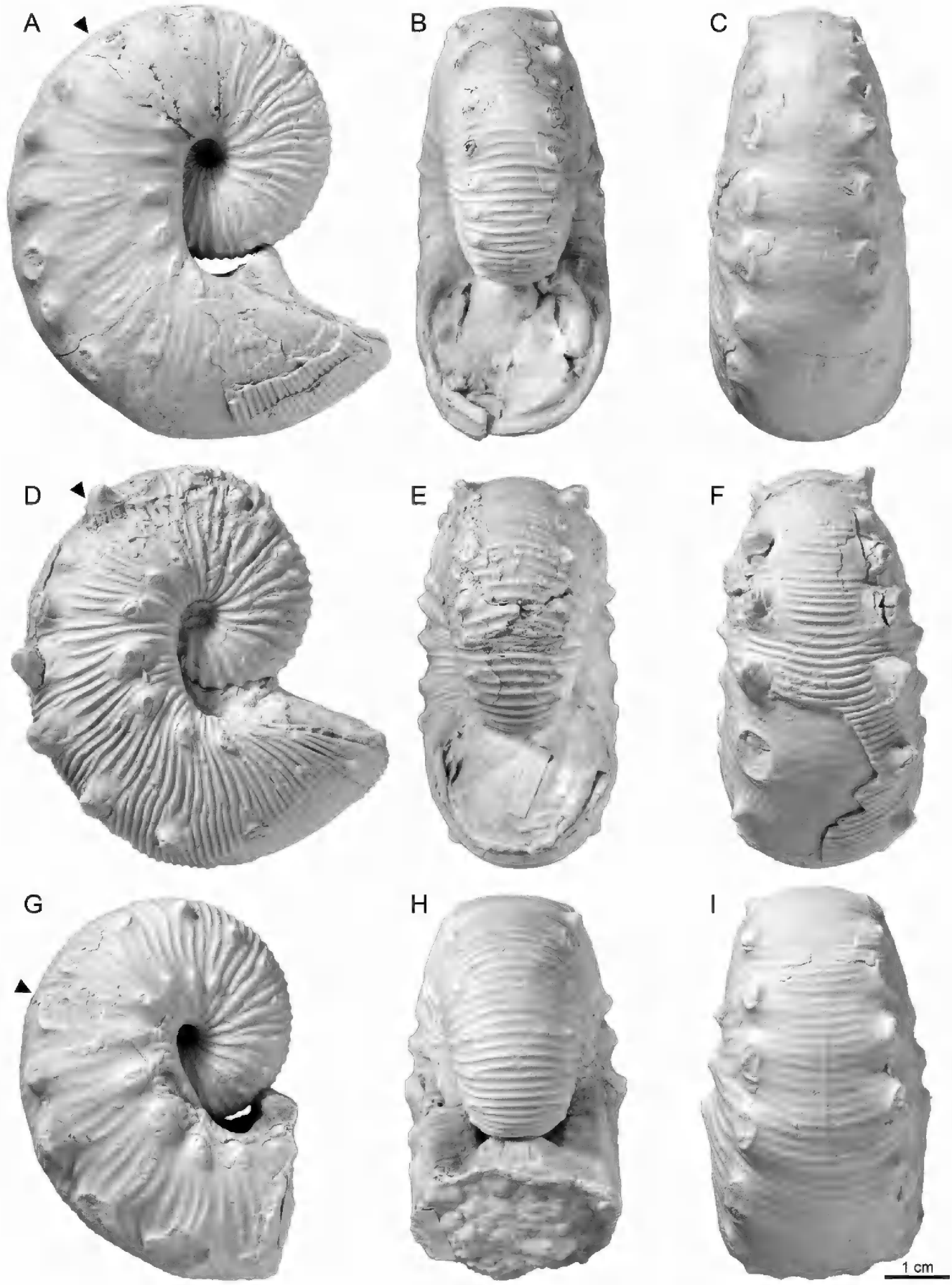

FIGURE 54. Hoploscaphites plenus (Meek and Hayden, 1860), microconchs. A-C. YPM 250650, YPM loc. A6521, Fort Yates, Sioux County, North Dakota (dubious locality). A, Right lateral; B, apertural; C, ventral. D-F. AMNH 76342, AMNH loc. 3921, lower Baculites baculus Zone, Pierre Shale, Cedar Creek Anticline, east-central Montana. D, Right lateral; E, apertural; F, ventral. G-I. AMNH 82964, AMNH loc. 3270, Baculites baculus Zone, Pierre Shale, Dawson County, Montana. H, apertural; I, ventral. Arrow indicates the base of the body chamber. 

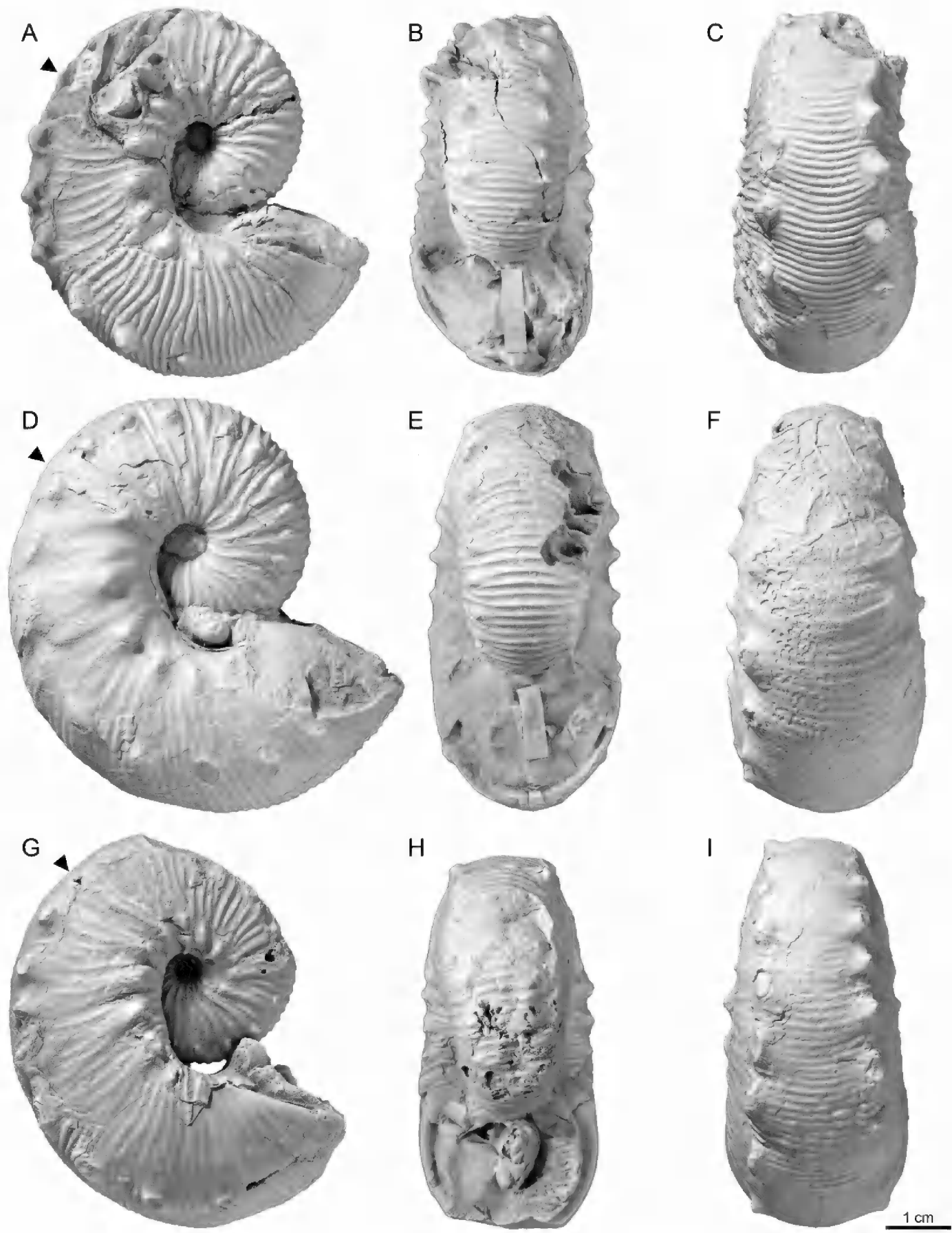

FIGURE 55. Hoploscaphites plenus (Meek and Hayden, 1860), microconchs. A-C. AMNH 85515, AMNH loc. 3921, lower Baculites baculus Zone, Pierre Shale, Cedar Creek Anticline, east-central Montana. A, Right lateral; B, apertural; C, ventral. D-F. AMNH 72540, AMNH loc. 3921, Baculites baculus or lower B. grandis Zone, Pierre Shale, Cedar Creek Anticline, east-central Montana. D, Right lateral; E, apertural; F, ventral. G-I. YPM 35681, YPM loc. A6521, Fort Yates, Sioux County, North Dakota (dubious locality). G, Right lateral; H, apertural; I, ventral. Arrow indicates the base of the body chamber. 
A

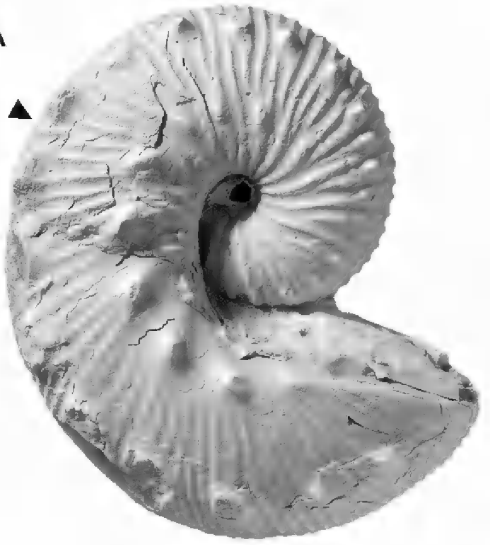

B
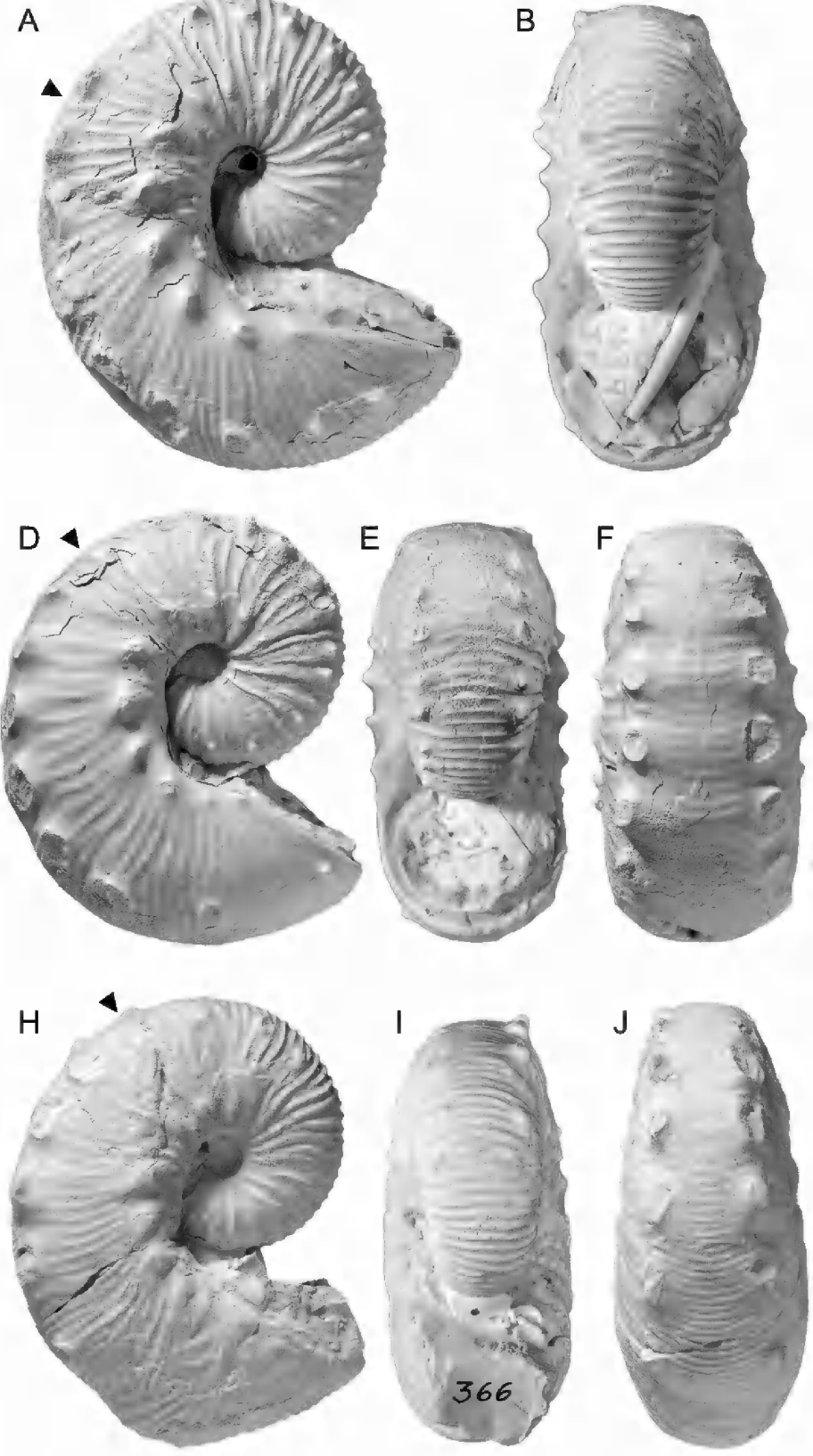
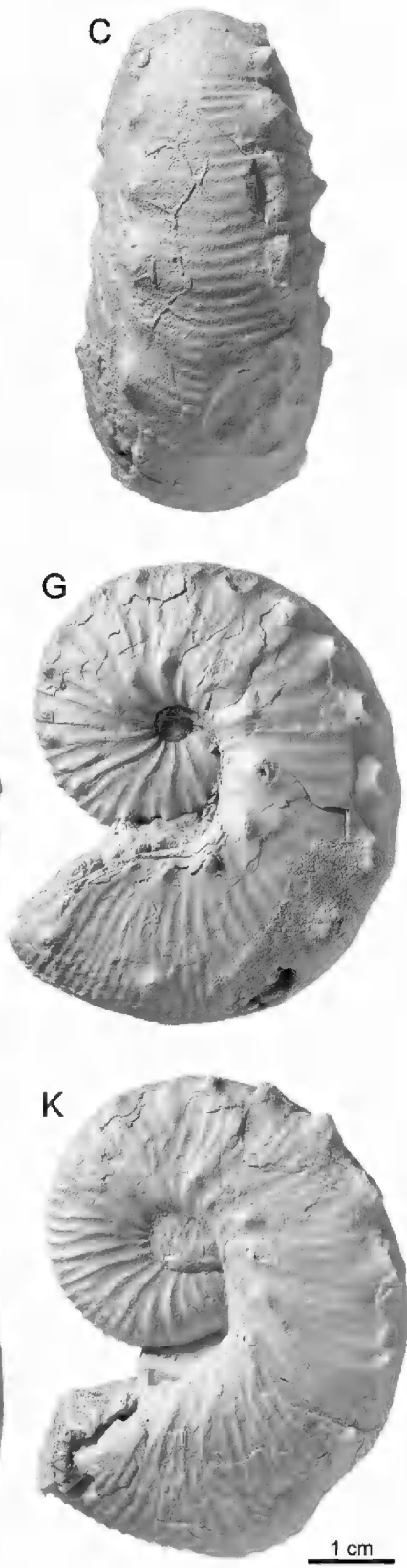

FIGURE 56. Hoploscaphites plenus (Meek and Hayden, 1860), microconchs. A-C. AMNH 135970, AMNH loc. 3921, lower Baculites baculus Zone, Pierre Shale, Cedar Creek Anticline, east-central Montana. A, Right lateral; B, apertural; C, ventral. D-G. AMNH 135991, AMNH loc. 3921, Baculites baculus or lower B. grandis Zone, Pierre Shale, Cedar Creek Anticline, east-central Montana. D, Right lateral; E, apertural; F, ventral; G, left lateral. H-K. USNM 366 (cast of holotype of Scaphites nodosus var. quadrangularis), illustrated in Meek (1876: pl. 25, fig. 3a-c), said to be from the Pierre Shale on the "Yellowstone River, Montana, 150 miles above its mouth," and probably, more specifically, from the Cedar Creek Anticline, Dawson County, Montana. H, Right lateral; I, apertural; J, ventral; K, left lateral. Arrow indicates the base of the body chamber. 

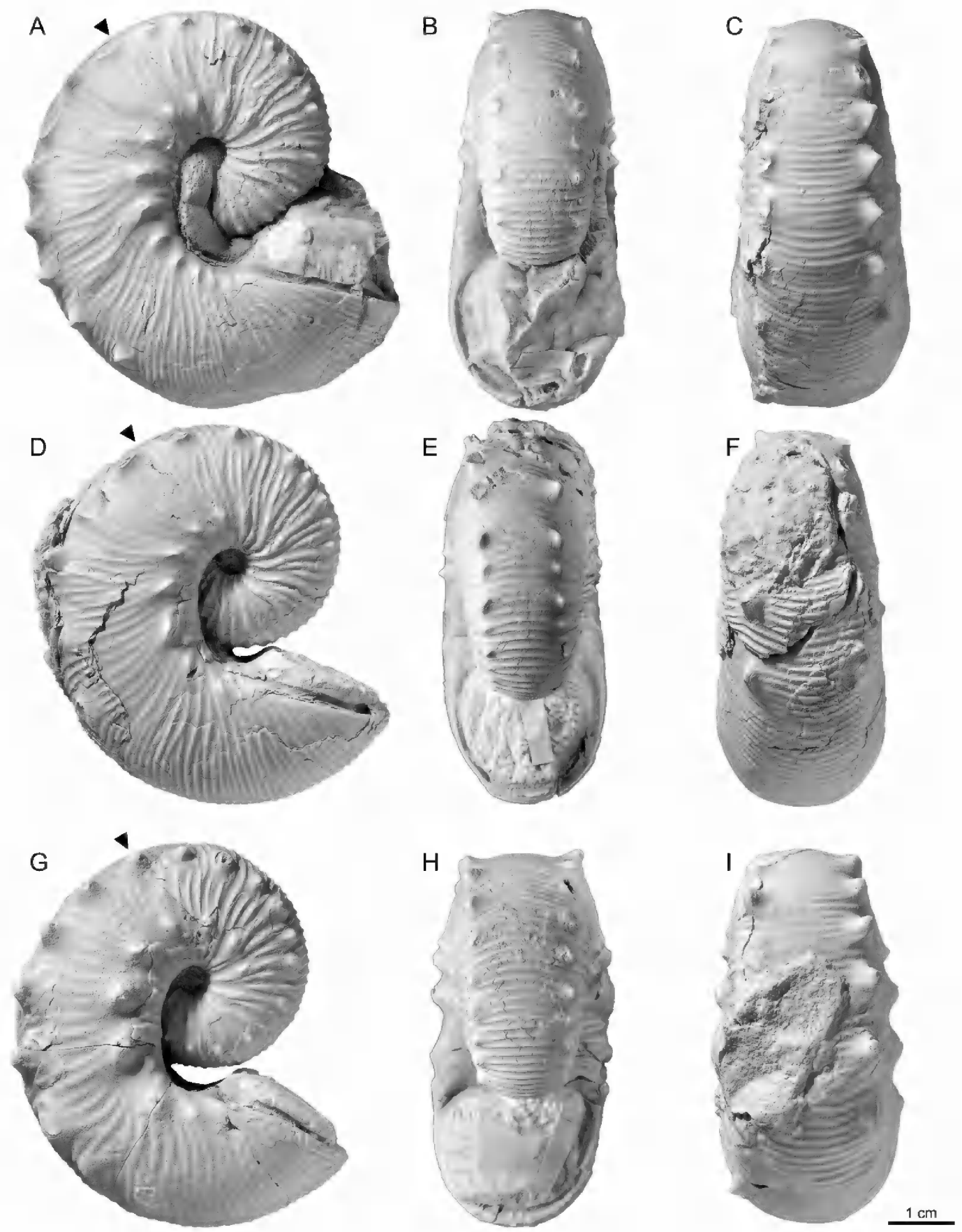

FIGURE 57. Hoploscaphites plenus (Meek and Hayden, 1860), microconchs. A-C. YPM 1971, YPM loc. 1503, Baculites baculus or lower B. grandis Zone, Pierre Shale, Wibaux (= Mingusville), Wibaux County, Montana. A, Right lateral; B, apertural; C, ventral. D-F. AMNH 135974, AMNH loc. 3921, Baculites baculus or lower B. grandis Zone, Pierre Shale, Cedar Creek Anticline, east-central Montana. D, Right lateral; E, apertural; F, ventral. G-I. AMNH 135981, AMNH loc. 3921, upper Baculites baculus or lower B. grandis Zone, Pierre Shale, Cedar Creek Anticline, east-central Montana. G, Right lateral; H, apertural; I, ventral. Arrow indicates the base of the body chamber. 

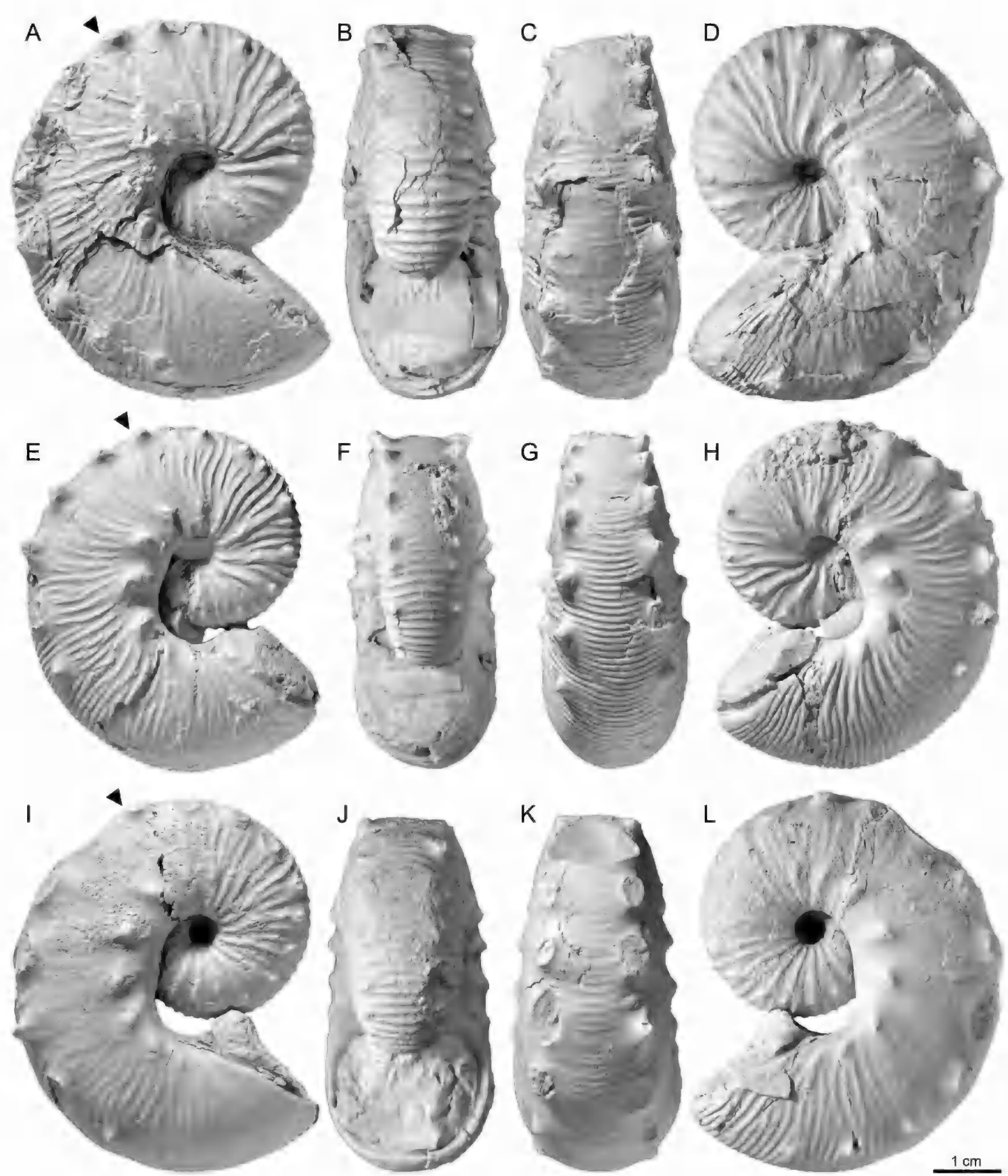

FIGURE 58. Hoploscaphites plenus (Meek and Hayden, 1860), microconchs. A-D. AMNH 105896, AMNH loc. 3921, lower Baculites baculus Zone, Pierre Shale, Cedar Creek Anticline, east-central Montana. A, Right lateral; B, apertural; C, ventral. D, left lateral. E-H. AMNH 135983, AMNH loc. 3921, Baculites baculus or lower B. grandis Zone, Pierre Shale, Cedar Creek Anticline, east-central Montana. E, Right lateral; F, apertural; G, ventral; H, left lateral. I-L. YPM 35597, YPM loc. 1503, Baculites baculus or lower B. grandis Zone, Pierre Shale, Wibaux (= Mingusville), Montana. I, Right lateral; J, apertural; K, ventral; L, left lateral. Arrow indicates the base of the body chamber. 


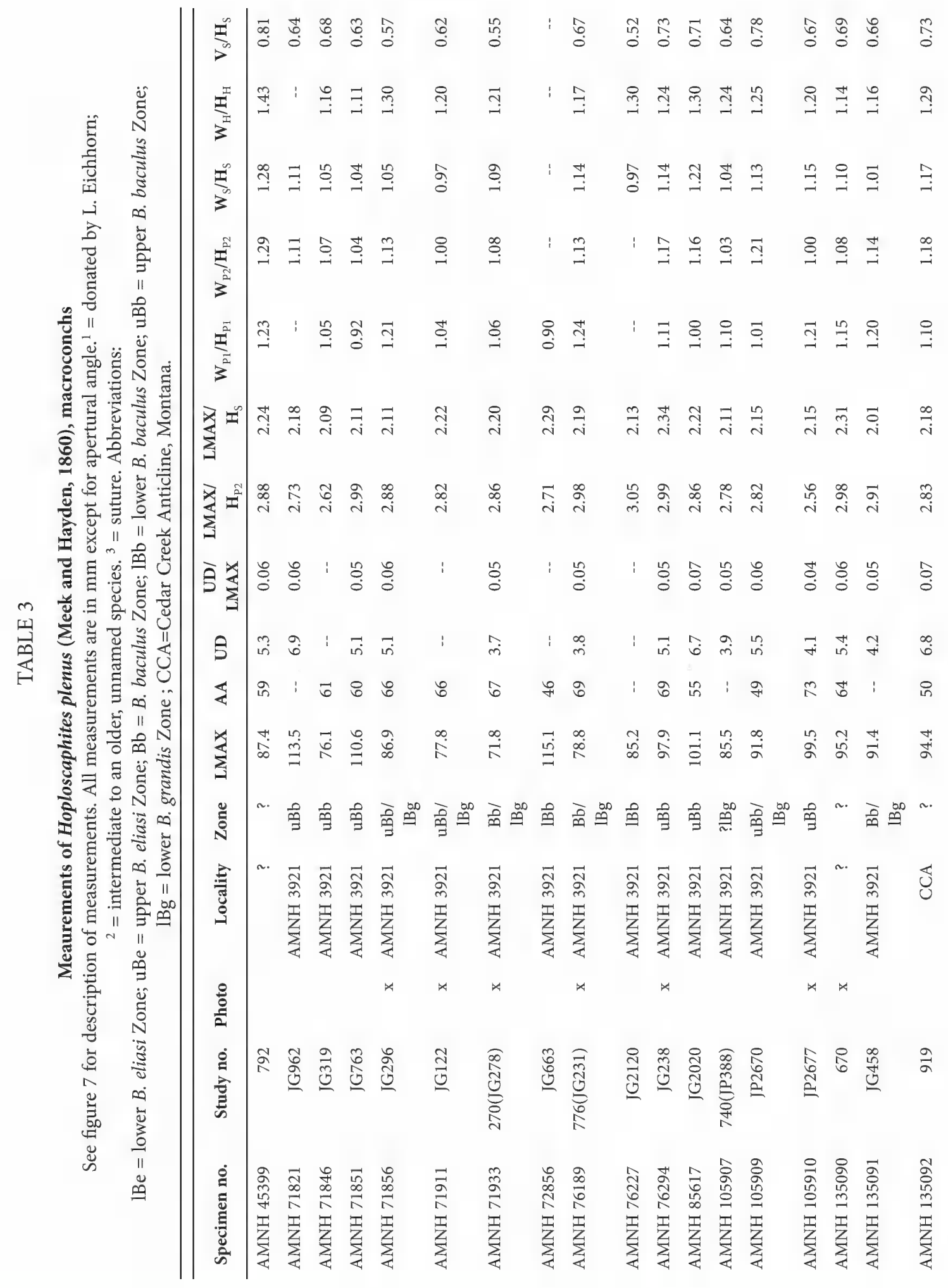




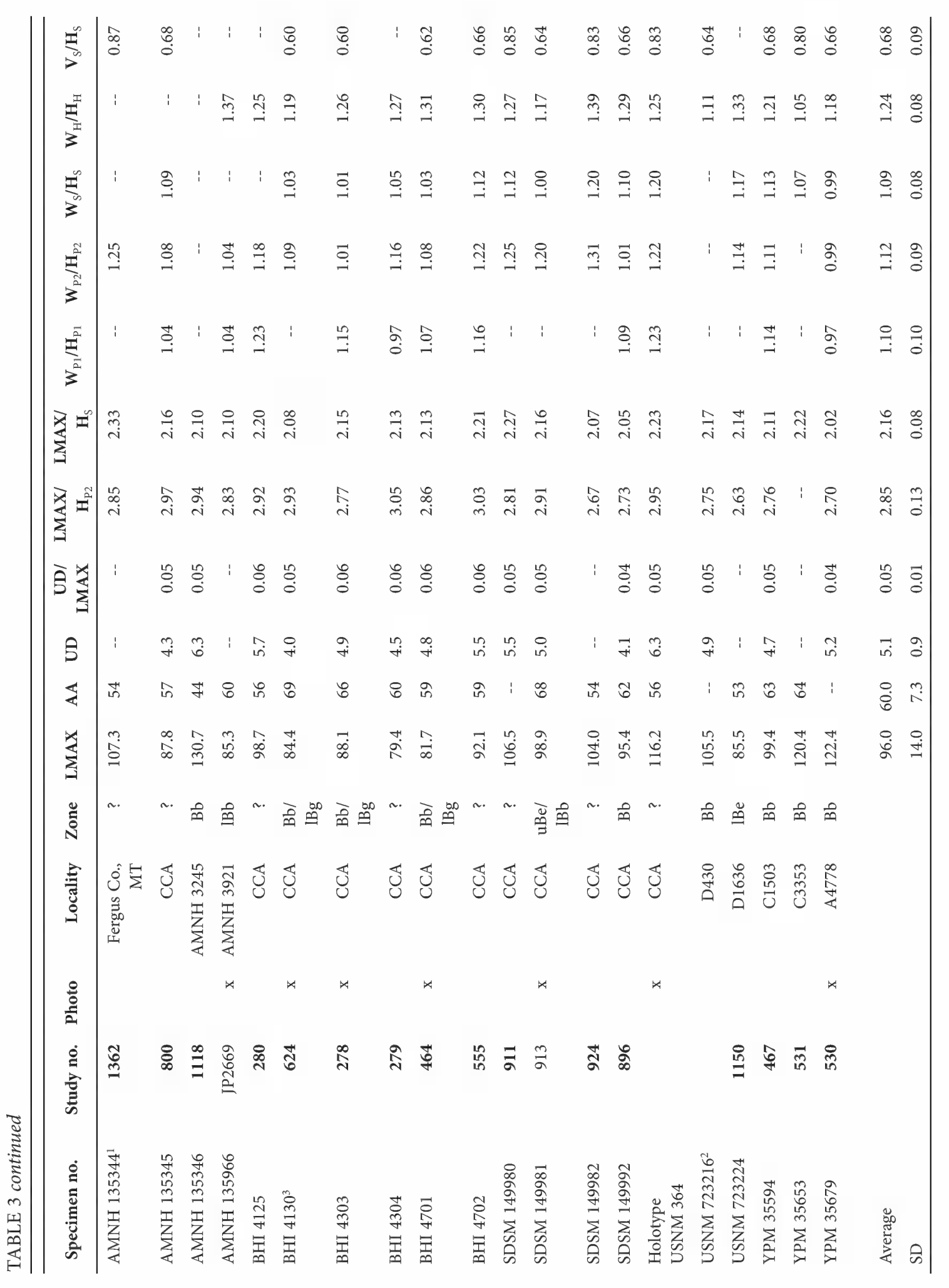




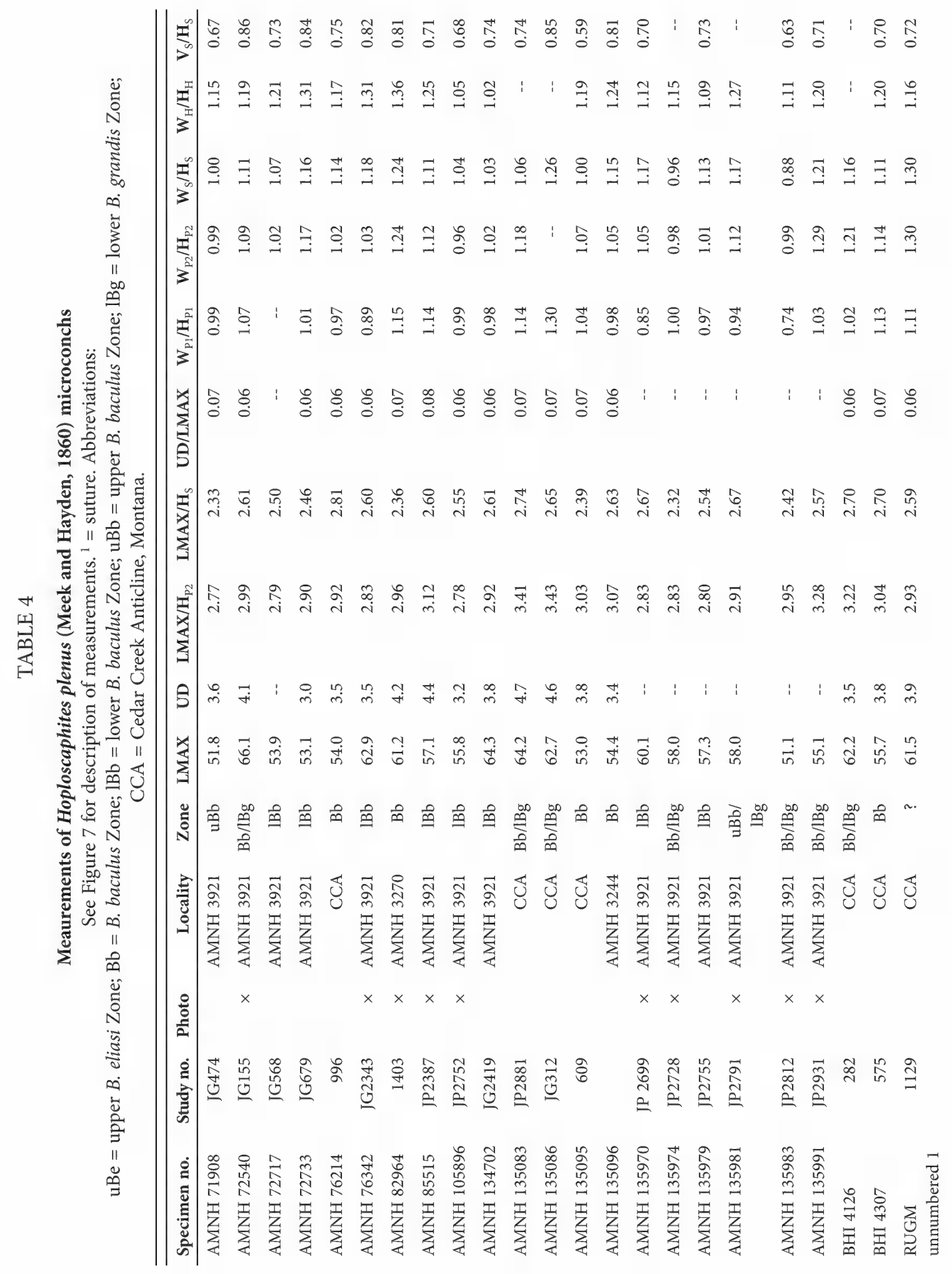




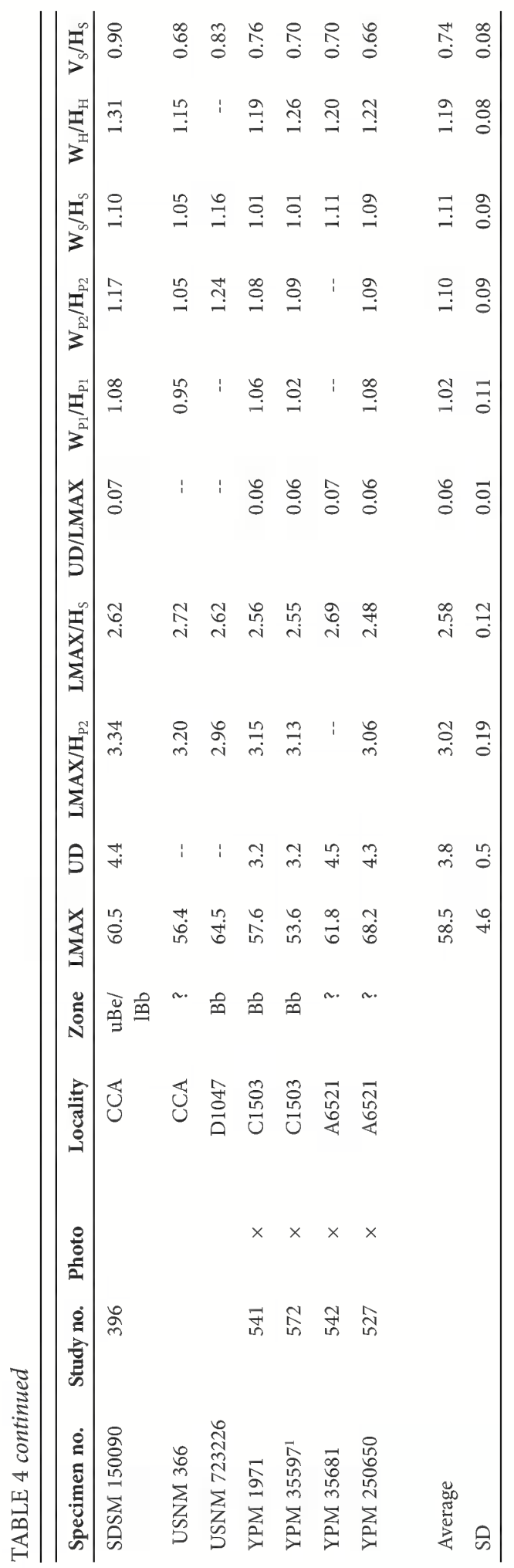


At midshaft, ribs are evenly and closely spaced on the umbilical wall, e.g., $12 \mathrm{ribs} / \mathrm{cm}$ on the umbilical wall in YPM 1971 (fig. 57A-C). They merge with or intercalate between umbilicolateral tubercles. Two ribs usually join an umbilicolateral tubercle dorsally and four ribs branch from it ventrally, with two ribs intercalating between tubercles. Ribs are prorsiradiate on the flanks, swinging slightly forward on the midflanks and slightly backward on the outer flanks, forming a broad convexity. In AMNH 76342 (fig. $54 \mathrm{D}-\mathrm{F}$ ) in which the ornamentation on the shaft is very well preserved, it appears that three ribs join a ventrolateral tubercle dorsally and four ribs branch from it ventrally, with as many as four ribs intercalating between tubercles. Ribs are closely and evenly spaced on the venter, which they cross with a strong adoral projection. The rib density on the venter at midshaft in $\mathrm{AMNH} 76342$ is $8 \mathrm{ribs} / \mathrm{cm}$ (fig. 54D-F). Ribs become progressively more prorsiradiate and closely spaced toward the aperture. For example, the rib density on the venter of the hook in AMNH 76342 is 9 ribs/cm (fig. 54D-F).

Umbilicolateral tubercles are present starting at the adoral end of the phragmocone. They continue onto the body chamber and usually persist to the aperture. They are perched on the umbilical shoulder at $1 / 4$ whorl height. They are evenly and moderately widely spaced on the body chamber. The distance between consecutive tubercles at midshaft ranges from 7 to $8.5 \mathrm{~mm}$. Although as noted above, two ribs usually join a tubercle dorsally, in many specimens such as AMNH 76342 (fig. 54D-F), tubercles also occur in the interspaces between ribs. A total of 9 or 10 umbilicolateral tubercles are present on the exposed shell.

Given the smaller size of microconchs compared to macroconchs, umbilicolateral tubercles are relatively more prominent on microconchs than they are on macroconchs. They are bullate and rectiradiate on the adapical end of the shaft, becoming progressively more prorsiradiate toward the aperture. In some specimens such as AMNH 76342 (fig. 54D-F), they develop into large clavi as much as $3 \mathrm{~mm}$ high, with steeply sloping adapical faces and gently sloping adoral faces.

Ventrolateral tubercles are present in all specimens starting at the adapical end of the exposed phragmocone. In YPM 1971(fig. 57A-C) in which the ornamentation is very well preserved, a total of 11 ventrolateral tubercles are present on the phragmocone. They occur at $7 / 8$ whorl height and become more widely spaced adorally, although the distance between them does not increase uniformly. For example, the distance between consecutive tubercles in this specimen, starting at the point of exposure, is $4.5,6,6,3.5$, $4.5,7,3.5,5,6$, and $6 \mathrm{~mm}$. Most of the tubercles are paired on opposite sides of the venter, but some are offset. The tubercles become increasingly larger toward the adoral end of the phragmocone and develop into clavi.

Ventrolateral tubercles continue onto the shaft and usually, but not always, extend to the aperture. For example, tubercles extend to the aperture in AMNH 76342 (fig. 54D-F), whereas they terminate at the adoral end of the shaft in AMNH 135983 (fig. 58E-H). As a result, the number of tubercles on the body chamber is higher in AMNH 76342 than in AMNH 135983 (9 vs. 6). Tubercles are more or less evenly spaced on the body chamber at intervals of 10-12 mm. The maximum distance between tubercles occurs on the adoral end of the shaft, e.g., $14 \mathrm{~mm}$ in AMNH 76342 (fig. 54D-F). Tubercles also become larger and more clavate in this area and attain a height of as much as $5 \mathrm{~mm}$. They exhibit steeply sloping adapical faces and gently sloping adoral faces, as shown in AMNH 76342 (fig. $54 \mathrm{D}-\mathrm{F})$. The top of each tubercle in this specimen forms a flat, inclined plane with a raised, horseshoe-shaped outer rim.

The suture of microconchs is similar to that of macroconchs (fig. 32D).

Discussion: What has traditionally been considered Hoploscaphites plenus is a large, fairly robust shell. However, our collection contains many smaller size specimens that we include in this species. The stratigraphic distribution of 
these smaller specimens is not well constrained (upper part of the Baculites baculus Zone-lower part of the B. grandis Zone) and requires further examination. Hoploscaphites plenus most closely resembles $H$. crassus from which it differs in having a more compressed whorl section with flatter flanks, and fewer, larger, and more widely spaced ventrolateral tubercles. However, as noted in the discussion about $H$. crassus, many specimens are intermediate between the two species.

Elias (1933, p. 314, pl. 36, fig. 2a-c; pl. 40, fig. 5) described and illustrated a small specimen as Scaphites plenus from the basal beds of the Salt Grass Member of the Pierre Shale in Wallace County, Kansas. It is a broken fragment $35 \mathrm{~mm}$ in diameter consisting mostly of phragmocone. The flanks are relatively flat and subparallel and the venter is broadly rounded; as a result, the whorl cross section is subquadrate. However, until the early ontogeny of Hoploscaphites plenus is more fully documented, we hesitate to attribute it to this species. In addition, the source of this specimen-the lower part of the Salt Grass Member-dates from the Baculites reesidei and B. jenseni zones (Gill et al., 1972: 10), and is older than any of our specimens of $H$. plenus.

In descriptions of Hoploscaphites plenus, much has been made about the presence of an incipient row of lateral tubercles on the adapical portion of the exposed phragmocone. Meek (1876: 429) described the holotype as showing "a slight tendency to develop a third intermediate series of very small lateral nodes about midway between the other rows, such as I have not seen in any of the other varieties. This tendency, however, is only marked by a scarcely perceptible swelling of the costae at this point." Such a row of slightly bullate swellings is also present, but rare, in specimens of $H$. crassus and $H$. peterseni. In contrast, lateral tubercles are much more common in the closely related, geologically younger species $H$. macer, $H$. sargklofak, and $H$. criptonodosus.

OCCURRence: Hoploscaphites plenus is abundant in the Baculites baculus Zone but also occurs in the B. eliasi and possibly the lower part of the $B$. grandis zones. It occurs in the Pierre Shale on the Cedar Creek Anticline, east-central Montana, and in Niobrara, Weston, and Crook counties, northeast Wyoming. It has also been reported en passant from the $B$. eliasi and $B$. baculus zones of the Bearpaw Shale of southern Saskatchewan and southern Alberta (Forester et al., 1977; Riccardi, 1983, and references therein).

\section{Hoploscaphites peterseni, n. sp.}

Figures 10A, 32E, 59-78

Macroconch Synonymy

1997. Jeletzkytes plenus. Larson et al., p. 81, unnumbered fig.

2019. Hoploscaphites sp. Landman et al., figs. 11E, F, 23F.

DiAGNosis: Macroconchs medium to large in size, nearly circular in outline; whorl cross section of shaft compressed subovoid with broadly rounded flanks and venter; width of venter approximately $60 \%$ whorl height; small umbilicus with umbilical bulge; apertural angle averaging $56^{\circ}$; long, fine, straight, closely spaced ribs on adoral part of phragmocone, with little branching or intercalation, and weak adoral projection on venter; long, fine, weakly concave, slightly more widely spaced ribs on shaft, with moderately strong adoral projection on venter; umbilicolateral tubercles absent or small and closely spaced on body chamber, forming a semicircle; ventrolateral tubercles small and closely spaced at $7 / 8$ whorl height, usually persisting to aperture. Microconchs medium to large in size, and more loosely uncoiled than macroconchs; umbilical wall of shaft broad and outwardly sloping; pattern of ornament similar to that on macroconchs, with relatively more prominent umbilicolateral tubercles. Suture deeply incised with broad-stemmed, asymmetrically bifid first lateral saddle.

EтумоLogy: This species is named in honor of Jack G. Petersen (Waterloo, Iowa) who, for over 25 years, collected and skillfully prepared 
hundreds of specimens of Eutrephoceras and Hoploscaphites from the Cedar Creek Anticline in east-central Montana. He has also generously donated many of these specimens to the AMNH for scientific research and display. It is fair to say that without Jack's contributions to this study, we would never have succeeded in conveying the richness and variety of the ammonites from the Cedar Creek Anticline.

TYPES: Following the traditional practice in scaphite systematics (Landman and Waage, 1993), we designate a macroconch rather than a microconch, as the holotype of this species. It is AMNH 71848 (fig. 60) from the Baculites baculus Zone or lower part of the B. grandis Zone of the Pierre Shale on the Cedar Creek Anticline in east-central Montana. It is a steinkern that retains some of its shell and is $88.7 \mathrm{~mm}$ in diameter with a weak umbilical bulge. It exhibits a repaired injury on the right side of the phragmocone near the point of exposure, which is manifested by an interruption in the ribbing. The macroconch paratypes are AMNH 41294 (fig. 61) and 105906 (fig. 70) from the B. baculus Zone from the same general site and USNM 723217 (fig. 67) from the B. eliasi Zone of the Bearpaw Shale, Valley County, Montana. The microconch paratypes are AMNH 76400 (fig. $77 \mathrm{G}-\mathrm{I}$ ) and 105901 (fig. 75A-D) from the $B$. baculus Zone or lower part of the $B$. grandis Zone, and the upper part of the B. baculus Zone, respectively, from the Pierre Shale on the Cedar Creek Anticline in east-central Montana.

MATERIAL: The collection consists of approximately 70 complete or nearly complete specimens of which 36 macroconchs and 26 microconchs comprise the measured set. Those for which we have detailed stratigraphic information are mostly from the lower part of the $B$. baculus Zone of the Pierre Shale on the Cedar Creek Anticline, east-central Montana, and the B. eliasi Zone of the Bearpaw Shale, Valley County, Montana.

Macroconch Description: Macroconchs are medium to large in size and robust. LMAX averages $87.8 \mathrm{~mm}$ and ranges from 69.5 to 114.6 $\mathrm{mm}$ (table 5). The holotype is in the middle of the size range $(\mathrm{LMAX}=88.7 \mathrm{~mm})$. The ratio of the size of the largest specimen to that of the smallest is 1.65 . The size distribution is bimodal with a primary peak at $75-80 \mathrm{~mm}$ and a secondary peak at 100-105 mm (fig. 59).

All specimens are circular in side view. LMAX/ $/ \mathrm{H}_{\mathrm{S}}$ averages 2.04, indicating that LMAX is approximately $2 \times$ the whorl height at midshaft, conforming nearly perfectly to the proportions of a circle. In addition, all specimens are tightly coiled with hardly any gap between the phragmocone and hook. $\mathrm{LMAX} / \mathrm{H}_{\mathrm{P} 2}$ averages 2.77 and ranges from 2.46 to 3.11 (3.11 in the holotype).

As in other species of Hoploscaphites, the phragmocone of the adult shell is relatively large and represents approximately $60 \%$ of the shell length. The phragmocone usually terminates adoral of the line of maximum length. The apertural angle is relatively high; it averages $56.3^{\circ}$ and ranges from $45^{\circ}$ to $67^{\circ}$. The apertural lip is flexuous with a deep constriction and accompanying varix. The dorsal margin of the aperture is bordered by an elongate, broadly rounded projection.

The umbilicus is small and deep. The umbilical diameter averages $4.2 \mathrm{~mm}$ and ranges from 2.6 to $5.6 \mathrm{~mm}$ (table 5). UD/LMAX averages 0.05 and ranges from 0.04 to 0.06 . In many specimens, the umbilicus is partially occluded by an umbilical bulge on the umbilical shoulder of the shaft. Due to the presence of the bulge, the outline of the umbilical shoulder is convex in lateral view. The umbilical bulge is prominent in AMNH 41294 (fig. 61) but not as well developed in the holotype (fig. 60).

The whorl section at the point of exposure is subovoid and nearly equidimensional, with maximum whorl width at $1 / 4$ whorl height. $\mathrm{W}_{\mathrm{P}_{1}} / \mathrm{H}_{\mathrm{P}_{1}}$ averages 1.03 and ranges from 0.73 to 1.24 (1.12 in the holotype). The umbilical wall is steep and convex and the umbilical shoulder is sharply rounded. The flanks are well rounded and gently converge toward the venter. The ventrolateral shoulder is sharply rounded and the venter is broadly rounded. 
In passing from the adapical to the adoral part of the phragmocone, both whorl width and whorl height increase, so that the shape of the whorl section of the phragmocone along the line of maximum length is approximately the same as that at the point of exposure. $\mathrm{W}_{\mathrm{P} 2} / \mathrm{H}_{\mathrm{P} 2}$ averages 1.04 and ranges from 0.78 to 1.24 (1.24 in the holotype). The cross section is subovoid with maximum whorl width at $1 / 3$ whorl height. The umbilical wall is steep and subvertical and the umbilical shoulder is sharply rounded. The flanks are broadly rounded and gently converge toward the venter.

Whorl width increases markedly and reaches its maximum value on the adoral part of the shaft, whereas whorl height reaches its maximum value at midshaft. $\mathrm{W}_{\mathrm{S}} / \mathrm{H}_{\mathrm{S}}$ averages 0.99 and ranges from 0.80 to 1.16 (1.08 in the holotype). The whorl section at midshaft is compressed subovoid, as in the holotype (fig. 60), or reniform, as in USNM 723217 (fig. 67), with maximum whorl width at $1 / 3$ whorl height. The umbilical wall is steep and weakly convex and the umbilicolateral shoulder is sharply rounded. The inner flanks are well rounded and the outer flanks are broadly rounded and converge steeply toward the venter. The ventrolateral shoulder is sharply rounded and the venter is broadly rounded. $\mathrm{V}_{\mathrm{S}} / \mathrm{H}_{\mathrm{S}}$ averages 0.58 and ranges from 0.46 to 0.73 ( 0.71 in the holotype), indicating that the width of the venter is, on average, slightly more than one-half the height of the whorl.

In passing from the shaft to the hook, the whorl width remains nearly the same. In contrast, the whorl height decreases markedly. As a result, the whorl section is more depressed at the point of recurvature than at midshaft. $\mathrm{W}_{\mathrm{H}} / \mathrm{H}_{\mathrm{H}}$ averages 1.16 and ranges from 0.93 to 1.37 (1.19 in the holotype). The umbilical shoulder is sharply rounded and the flanks are broadly rounded. The opening at the aperture is reduced in size relative to the whorl section at midshaft. It is subovoid and slightly depressed in the holotype (fig. 60).

At the point of exposure, ribs are straight and rectiradiate on the umbilical wall. They bend slightly backward on the inner flanks and pass between or merge with the umbilicolateral tubercles. In the holotype (fig. 60), one rib joins an umbilicolateral tubercle dorsally and three ribs branch from it ventrally, with one or two ribs intercalating between tubercles. The ribs bend forward on the outer flanks and form a broad convexity. Intercalation and branching occur on the outer margins of the outer flanks and at the ventrolateral tubercles. In the holotype, one or two ribs join a ventrolateral tubercle dorsally and two or three ribs branch from it ventrally, with an equal number of ribs intercalating between tubercles. The ribs that branch from tubercles on one side of the venter loop to tubercles on the other side of the venter. Ribs are uniformly strong and evenly spaced on the venter, and show a slight adoral projection. The rib density on the venter of the adapical end of the phragmocone in the holotype is $6 \mathrm{ribs} / \mathrm{cm}$.

On the adoral part of the phragmocone, ribs bend slightly backward on the umbilical wall. They are straight on the inner flanks, and bend forward on the midflanks and backward on the outer flanks, forming a broad convexity. Ribs are long, narrow, and closely spaced on the outer flanks, a pattern similar to that in Hoploscaphites crassus and $H$. plenus. Intercalation and branching occur on the outer flanks and at the umbilicolateral and ventrolateral tubercles. In the holotype, one rib joins an umbilicolateral tubercle dorsally and two ribs branch from it ventrally, with two ribs intercalating between tubercles. One or two ribs join a ventrolateral tubercle dorsally and groups of two or three ribs branch from it ventrally, which loop to paired tubercles on the opposite side of the venter, with one or two ribs intercalating between groups. Ribs are closely and evenly spaced on the venter, which they cross with a slight adoral projection. The rib density is higher on the adoral than on the adapical part of the phragmocone ( 7 vs. $6 \mathrm{ribs} / \mathrm{cm}$ in the holotype).

The shaft is covered with thin, closely spaced ribs. They bend slightly backward on the umbilical wall and shoulder. In the holotype, 10 ribs/ 
$\mathrm{cm}$ are present on the umbilical wall. Ribs bend strongly forward on the inner flanks and strongly backward on the outer flanks, forming a broad convexity. They are rectiradiate on the adapical end of the shaft and become progressively more prorsiradiate toward the adoral end of the shaft. As on the phragmocone, intercalation and branching occur on the outer flanks and at the sites of the umbilicolateral and ventrolateral tubercles. As a result, the midflanks are covered with a broad area of nonbifurcating ribs. In the holotype, one or two ribs join an umbilicolateral tubercle dorsally and two or three ribs branch from it ventrally, with as many as five ribs intercalating between tubercles. Two or three ribs join a ventrolateral tubercle dorsally and three or four ribs branch from it ventrally, with up to five ribs intercalating between tubercles. Because the ventrolateral tubercles are paired on opposite sides of the venter in the holotype, ribs that branch from a tubercle on one side of the venter loop to the tubercle on the other side of the venter. Ribs cross the venter with a moderately strong adoral projection. The rib density on the shaft of the holotype is the same as that on the adoral part of the phragmocone (7 ribs $/ \mathrm{cm}$ ).

As on the shaft, ribs on the flanks of the hook are narrow, prorsiradiate, and nearly straight, Intercalation and branching occur on the outer margins of the outer flanks and at the umbilicolateral and ventrolateral tubercles. Ribs cross the venter with a moderately strong adoral projection and become progressively more closely spaced toward the aperture, culminating in a rib density of $10 \mathrm{ribs} / \mathrm{cm}$ on the venter of the holotype.

Umbilicolateral tubercles are present in only one-half of the specimens in our collection. For example, they are present in the holotype starting at the point of exposure (fig. 60), but are absent in AMNH 41294 (fig. 61). The tubercles occur at $1 / 3$ whorl height and are evenly spaced, becoming slightly more widely spaced toward the adoral end of the phragmocone. In the holotype, the distance between the two most adoral tubercles on the phragmocone is $5 \mathrm{~mm}$. The tubercles are small with a maximum height of 1 $\mathrm{mm}$ and are elongated radially. A total of seven tubercles are present on the phragmocone of the holotype. Some of these tubercles do not occur on the ribs themselves but rather in the interspaces between them.

In those specimens in which umbilicolateral tubercles are present on the phragmocone, the tubercles continue onto the body chamber, usually persisting to the aperture. They occur at $1 / 3$ whorl height and are arranged in a semicircle paralleling the outline of the venter in side view. They gradually become more widely spaced and attain their maximum spacing at midshaft, after which they become more closely spaced. The maximum distance between tubercles in the holotype is $9 \mathrm{~mm}$. As on the phragmocone, the umbilicolateral tubercles on the body chamber are small, with a maximum height of $1 \mathrm{~mm}$. They are bullate and follow the curvature of the ribs, so that the tubercles on the midshaft and hook are elongated in a prorsiradiate direction. A total of 6 umbilicolateral tubercles are present on the body chamber of the holotype, so that the total number of tubercles on the exposed shell of this specimen is 11 .

All specimens bear ventrolateral tubercles starting at the point of exposure. They occur at $7 / 8$ whorl height and are more or less evenly spaced, with maximum spacing at the adoral end of the phragmocone. However, in many specimens, the tubercles are grouped in clusters. For example, in the holotype (fig. 60), the distance between consecutive tubercles on the exposed phragmocone on the left side, starting at the point of exposure, is $8,4,6.5,11,6.5,7.5,6,7.5$, 8.5 , and $7.5 \mathrm{~mm}$. A total of 11 ventrolateral tubercles are present on the phragmocone of the holotype and are paired on opposite sides of the venter. In contrast, in SDSM 149991 (fig. 64), the ventrolateral tubercles are offset from one side of the venter to the other. Tubercles are conical in shape and slightly elongated radially, with a maximum height of $3 \mathrm{~mm}$.

Ventrolateral tubercles extend onto the body chamber and, almost always, persist to the aper- 
ture. They are moderately widely spaced and nearly evenly distributed, forming a pattern similar to that in Hoploscaphites crassus. The tubercles attain their maximum spacing on the adoral one-third of the shaft (11.5 $\mathrm{mm}$ in the holotype), after which they become more closely spaced. Similarly, the tubercles attain their maximum size on the adoral one-third of the shaft, after which they decrease in size. In many specimens, such as SDSM 149990 (fig. 71), the tubercles develop into clavi with a maximum height of 3 $\mathrm{mm}$. A total of 14 ventrolateral tubercles occurs on the body chamber of the holotype, so that the total number of ventrolateral tubercles on the exposed shell of this specimen is 25 .

Lateral tubercles are very rare. In the holotype (fig. 60), one bullate tubercle occurs on the adapical end of the phragmocone on the left side of the specimen just dorsal of the ventrolateral tubercle. Similarly, in SDSM 149991 (fig. 64), two bullate tubercles are present on the adapical end of the phragmocone on the right side of the specimen just dorsal of the ventrolateral tubercles.

The suture is deeply incised with a broad stemmed and asymmetrically bifid first lateral saddle (E/L) and a narrow, symmetrically bifid first lateral lobe (L) that is nearly as deep as the ventral lobe (fig. 32E).

Microconch Description: Microconchs are smaller and more loosely uncoiled than macroconchs, but exhibit a similar ornamentation and shape of the whorl section. LMAX averages $58.1 \mathrm{~mm}$ and ranges from 44.2 to $79.1 \mathrm{~mm}$ (table 6 ). The size distribution is unimodal with a peak at $50-55 \mathrm{~mm}$ (fig. 59). The ratio of the average size of microconchs to that of macroconchs is 0.66. The umbilical shoulder of the shaft in microconchs is concave in lateral view and parallels the curvature of the venter. UD averages 3.5 $\mathrm{mm}$ and ranges from 2.6 to $4.5 \mathrm{~mm}$ (table 6). UD/LMAX averages 0.06 and ranges from 0.05 to 0.07 . In AMNH 76311 (fig. 78E-H), the umbilical diameter on the right side is much larger than that on the left side due to a pathology. As noted, microconchs are more loosely uncoiled than macroconchs. This difference is expressed by the ratio $\mathrm{LMAX} / \mathrm{H}_{\mathrm{P} 2}$, which averages 2.98 in microconchs versus 2.77 in macroconchs.

The whorl section at the adapical end of the phragmocone is compressed subquadrate with maximum whorl width at $1 / 4$ whorl height. $\mathrm{W}_{\mathrm{Pl}}$ / $\mathrm{H}_{\mathrm{P} 1}$ averages 0.94 and ranges from 0.74 to 1.09 (table 6). The umbilical wall is steep and subvertical and the umbilical shoulder is sharply rounded. The flanks are broadly rounded and the ventrolateral shoulder is sharply rounded. The whorl section at the adoral end of the phragmocone is more depressed than that at the adapical end because of a larger increase in whorl width than whorl height. $\mathrm{W}_{\mathrm{P} 2} / \mathrm{H}_{\mathrm{P} 2}$ averages 1.05 and ranges from 0.93 to 1.22 . The whorl section is compressed subovoid with maximum whorl width at $1 / 3$ whorl height. The inner flanks are well rounded, and the outer flanks are more broadly rounded and gently converge toward the venter.

Whorl width and height both increase in passing into the shaft. Whorl width attains its maximum value at the point of recurvature whereas whorl height attains its maximum value at midshaft. The whorl section at midshaft is subquadrate to reniform with maximum whorl width at $1 / 4$ whorl height, coincident with the position of the umbilicolateral tubercles. $\mathrm{W}_{\mathrm{S}} / \mathrm{H}_{\mathrm{S}}$ averages 1.03 and ranges from 0.78 to 1.18 . The umbilical wall is broad and slopes outward, and the umbilical shoulder is sharply rounded. The flanks are broadly rounded to nearly flat and gently converge toward the venter. The ventrolateral shoulder is sharply rounded and the venter is broadly rounded. $\mathrm{V}_{\mathrm{S}} / \mathrm{H}_{\mathrm{S}}$ averages 0.67 and ranges from 0.55 to 0.80 , indicating that, on average, the venter is slightly more than one-half as wide as the whorl is high. The whorl section at the point of recurvature is more depressed; $\mathrm{W}_{\mathrm{H}} / \mathrm{H}_{\mathrm{H}}$ averages 1.14 and ranges from 0.82 to 1.32 .

On the exposed phragmocone, ribs arise at the umbilical seam and are straight to slightly rursiradiate on the umbilical wall. They are 


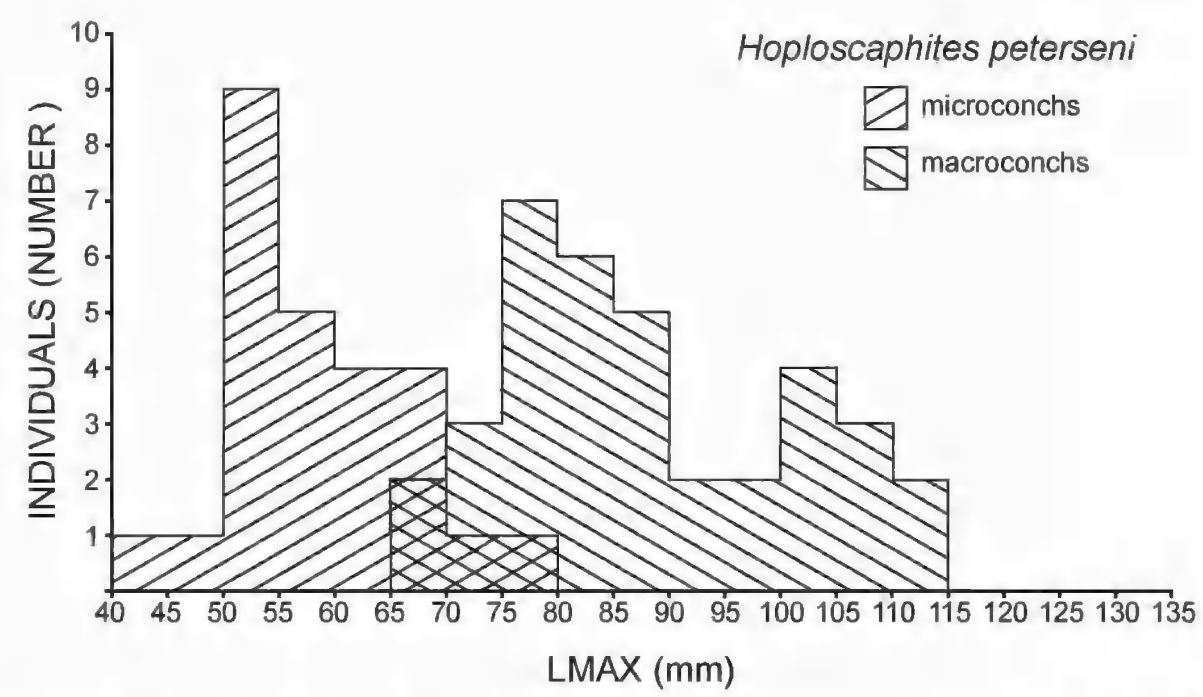

FIGURE. 59. Size frequency histogram of Hoploscaphites peterseni, based on the samples in tables 5 and 6.

weakly flexuous on the flanks, swinging slightly backward on the inner flanks, slightly forward on the midflanks, and slightly backward again on the outer flanks. On the adoral end of the phragmocone, where umbilicolateral tubercles appear, one rib usually joins an umbilicolateral tubercle dorsally and three ribs branch from it ventrally, with two ribs intercalating between tubercles. Additional branching and intercalation occur on the outer flanks and at the ventrolateral tubercles. One rib usually joins a ventrolateral tubercle dorsally and two ribs branch from it ventrally, with an equal number of ribs intercalating between tubercles. Ribs are uniformly and evenly spaced on the venter, which they cross with a slight adoral projection. The rib density on the venter on the adoral part of the phragmocone is 7 or $8 \mathrm{ribs} / \mathrm{cm}$.

Ribs are closely spaced and slightly rursiradiate on the umbilical wall of the shaft. They are moderately widely spaced and prorsiradiate on the flanks. They swing forward on the inner flanks and backward on the outer flanks, forming a broad convexity. Intercalation and branching occur on the outer flanks and at the umbilicolateral and ventrolateral tubercles. One rib usually joins an umbilicolateral tubercle dorsally and three ribs branch from it ventrally, with up to three ribs intercalating between tubercles. In AMNH 105901 (fig. 75A-D), three or four ribs join a ventrolateral tubercle dorsally and five to seven ribs branch from it ventrally, with one to three ribs intercalating between tubercles. The result of so much branching at the ventrolateral tubercles is that the venter is covered with fine, closely spaced ribs. The rib density on the venter at midshaft in this specimen is $9 \mathrm{ribs} / \mathrm{cm}$. Ribs become progressively more prorsiradiate and closely spaced toward the aperture.

Umbilicolateral tubercles appear on the adoral end of the exposed phragmocone. They strengthen on the shaft and usually persist to the aperture. They are perched on the umbilical shoulder at $1 / 3$ whorl height. The umbilicolateral tubercles in microconchs are relatively stronger than they are in macroconchs. They are bullate and become progressively more prorsiradiate toward the aperture. In many specimens, they develop into clavi as much as $2 \mathrm{~mm}$ high, with steep adapical faces and gently sloping adoral faces. They are evenly and moderately widely spaced; the maximum distance between tubercles usually occurs at midshaft, e.g., $8.5 \mathrm{~mm}$ in AMNH 76400 (fig. 77G-I). The number of umbilicolateral tubercles on the exposed shell ranges from 4 to 6 . 


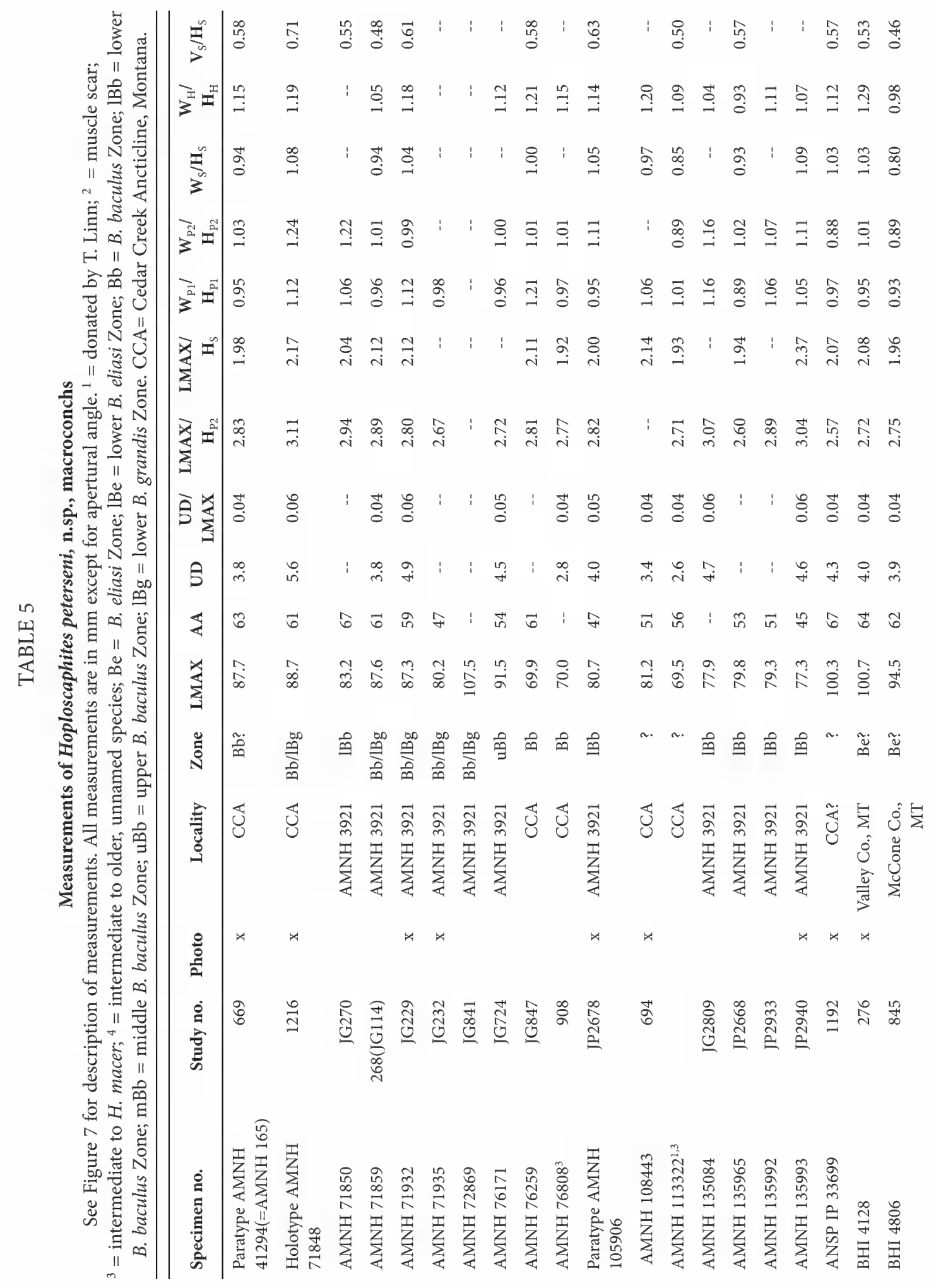




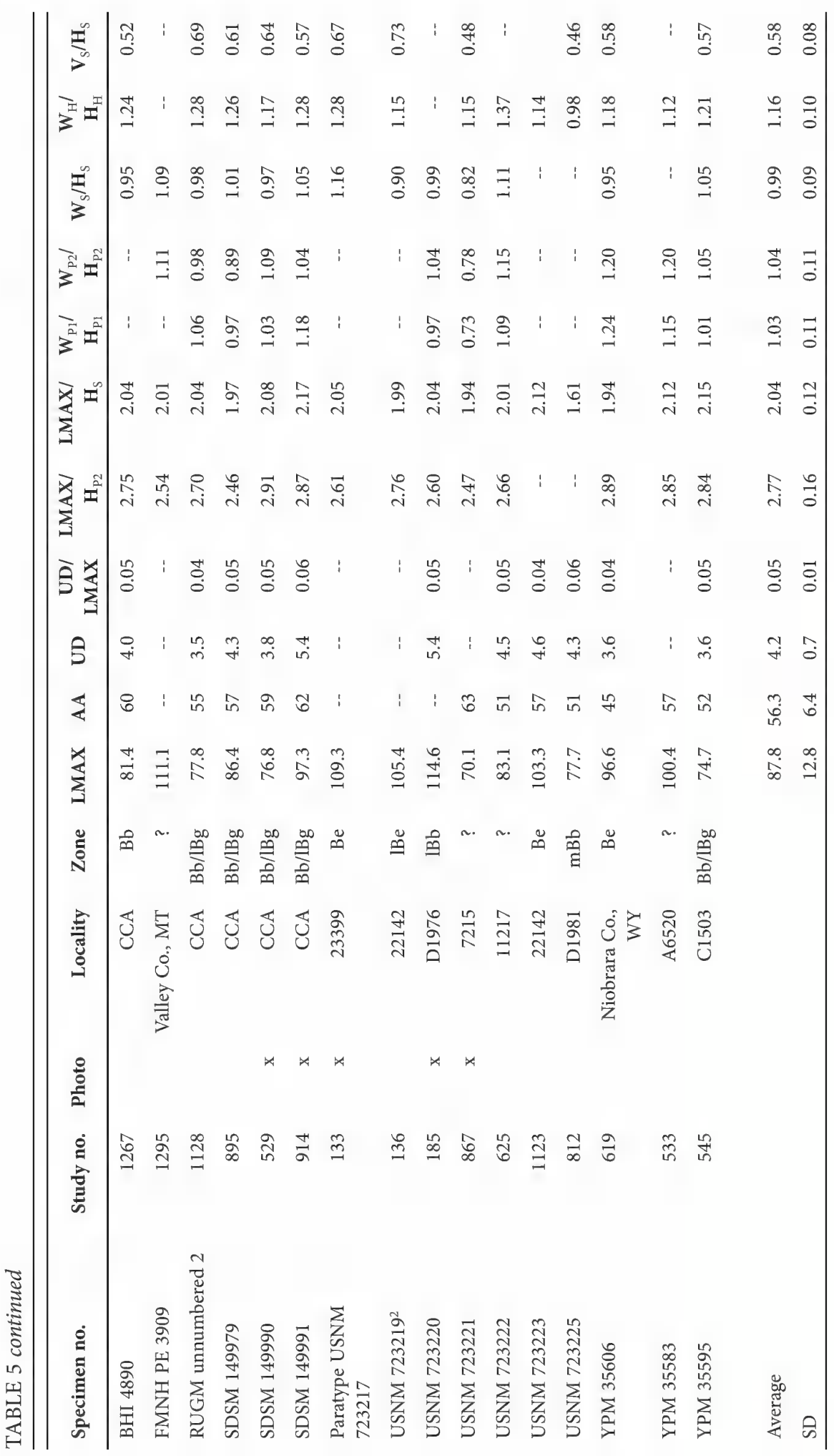




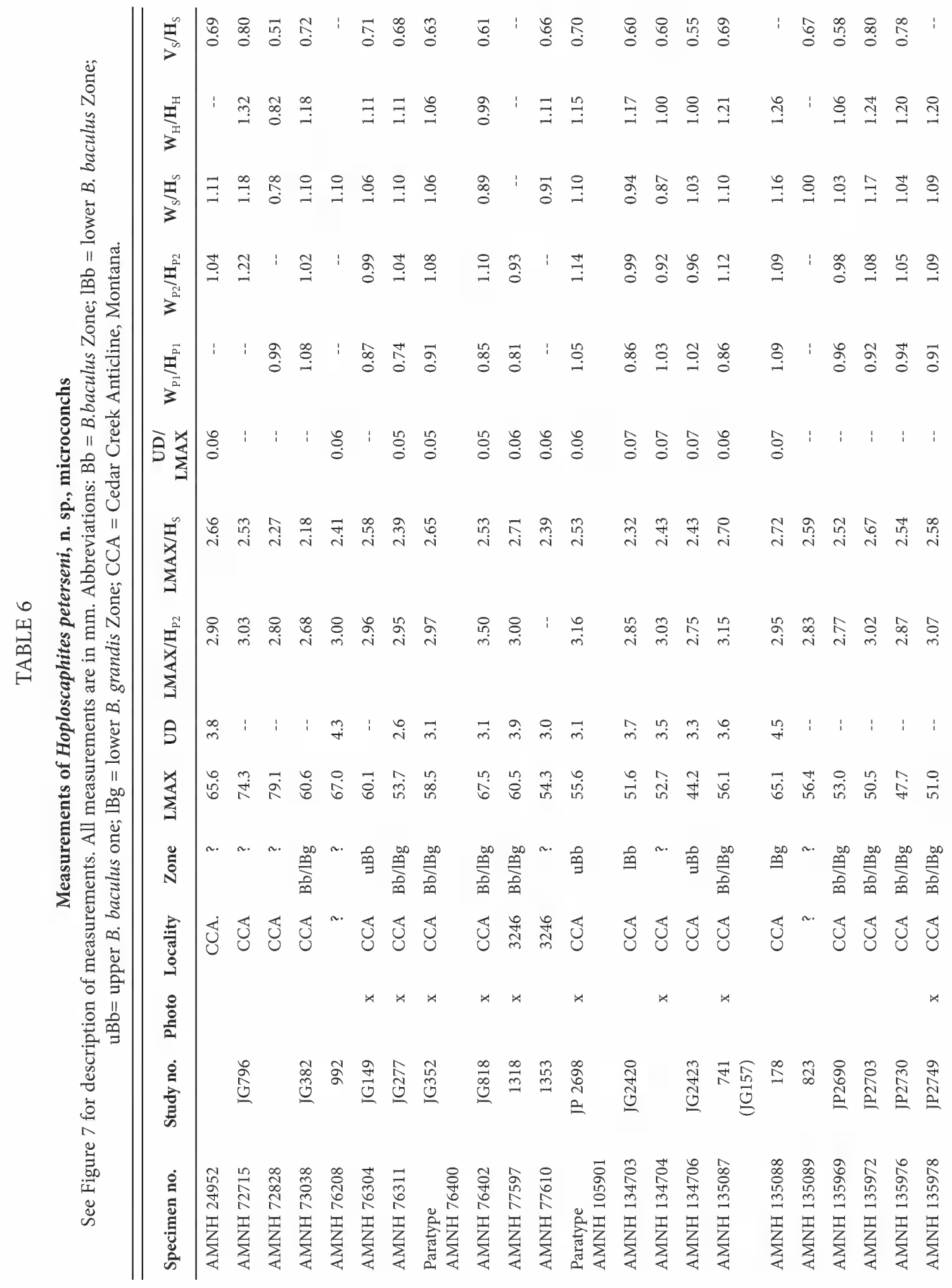




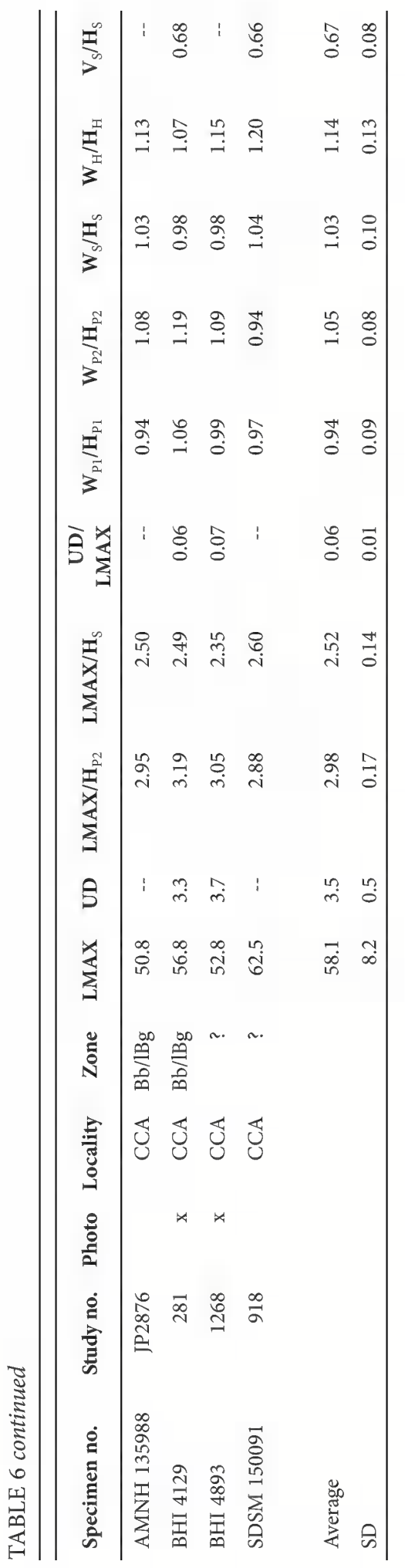



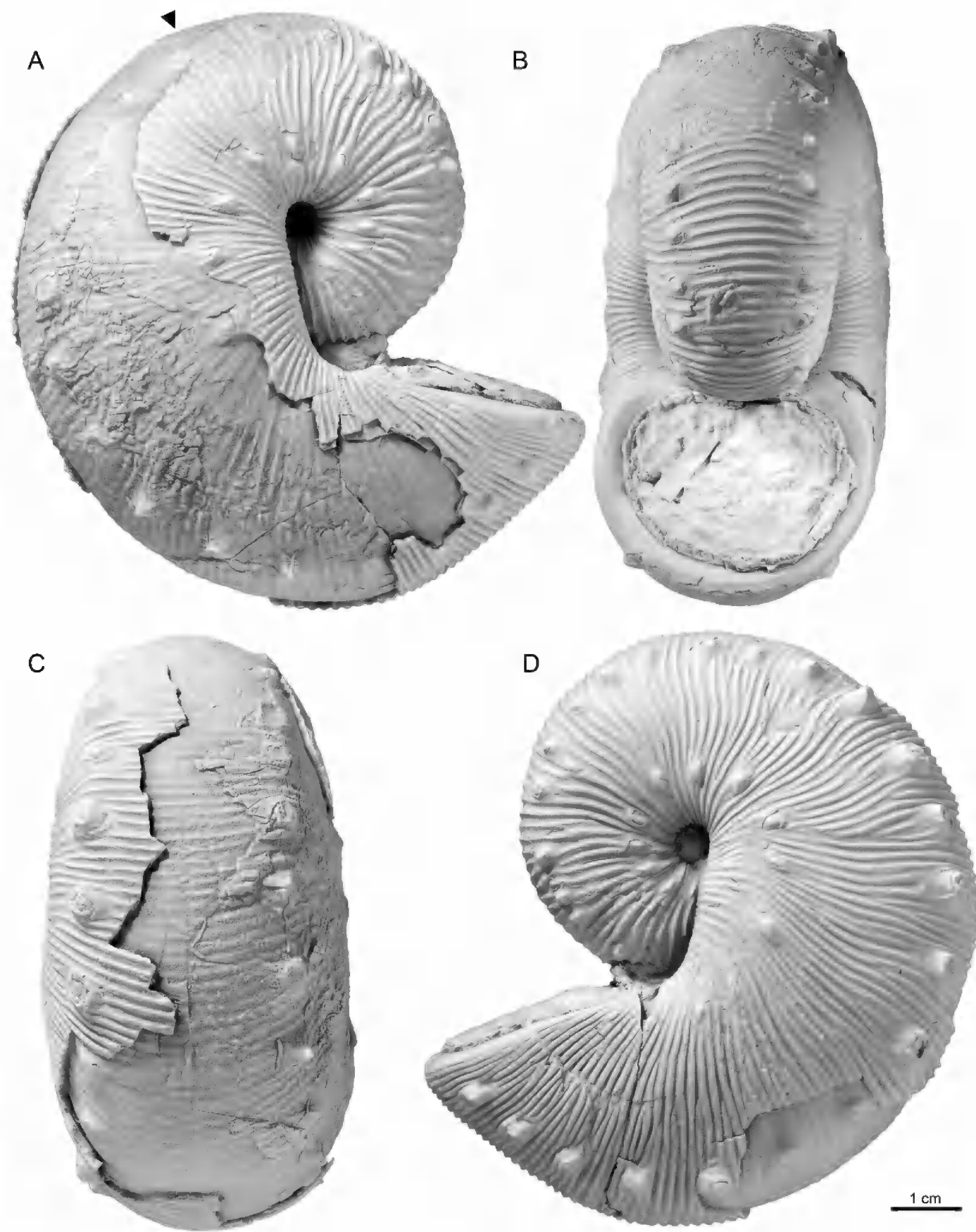

FIGURE 60. Hoploscaphites peterseni, macroconch, holotype. A-D. AMNH 71848, AMNH loc. 3921, Baculites baculus or lower B. grandis Zone, Pierre Shale, Cedar Creek Anticline, east-central Montana. A, Right lateral; B, apertural; C, ventral; D, left lateral. Arrow indicates the base of the body chamber. 

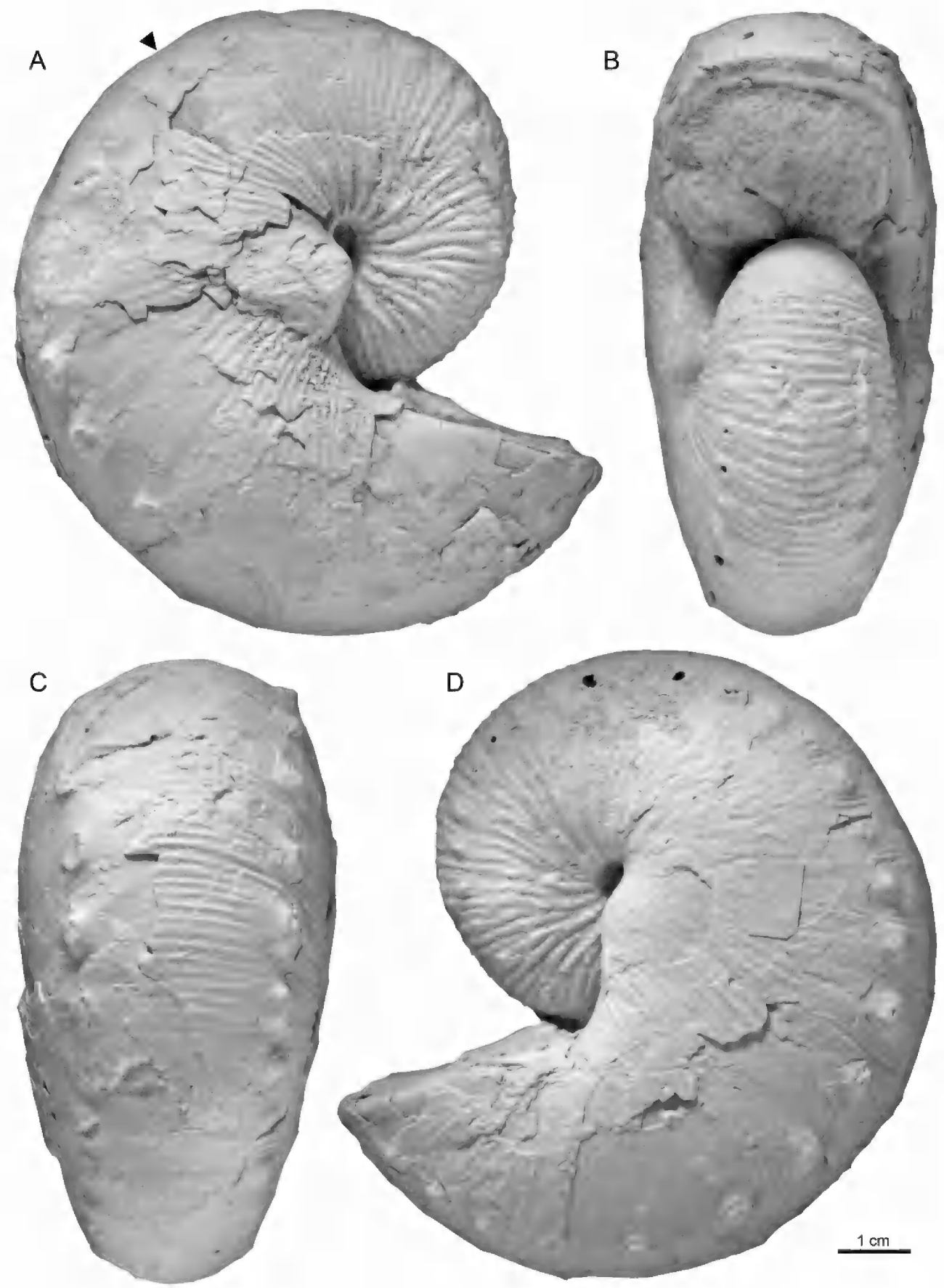

FIGURE 61. Hoploscaphites peterseni, macroconch, paratype. A-D. AMNH 41294 (formerly AMNH 165), Baculites baculus or lower B. grandis Zone, Pierre Shale, Dawson County, Montana. A, Right lateral; B, apertural; C, ventral; D, left lateral. Arrow indicates the base of the body chamber. 

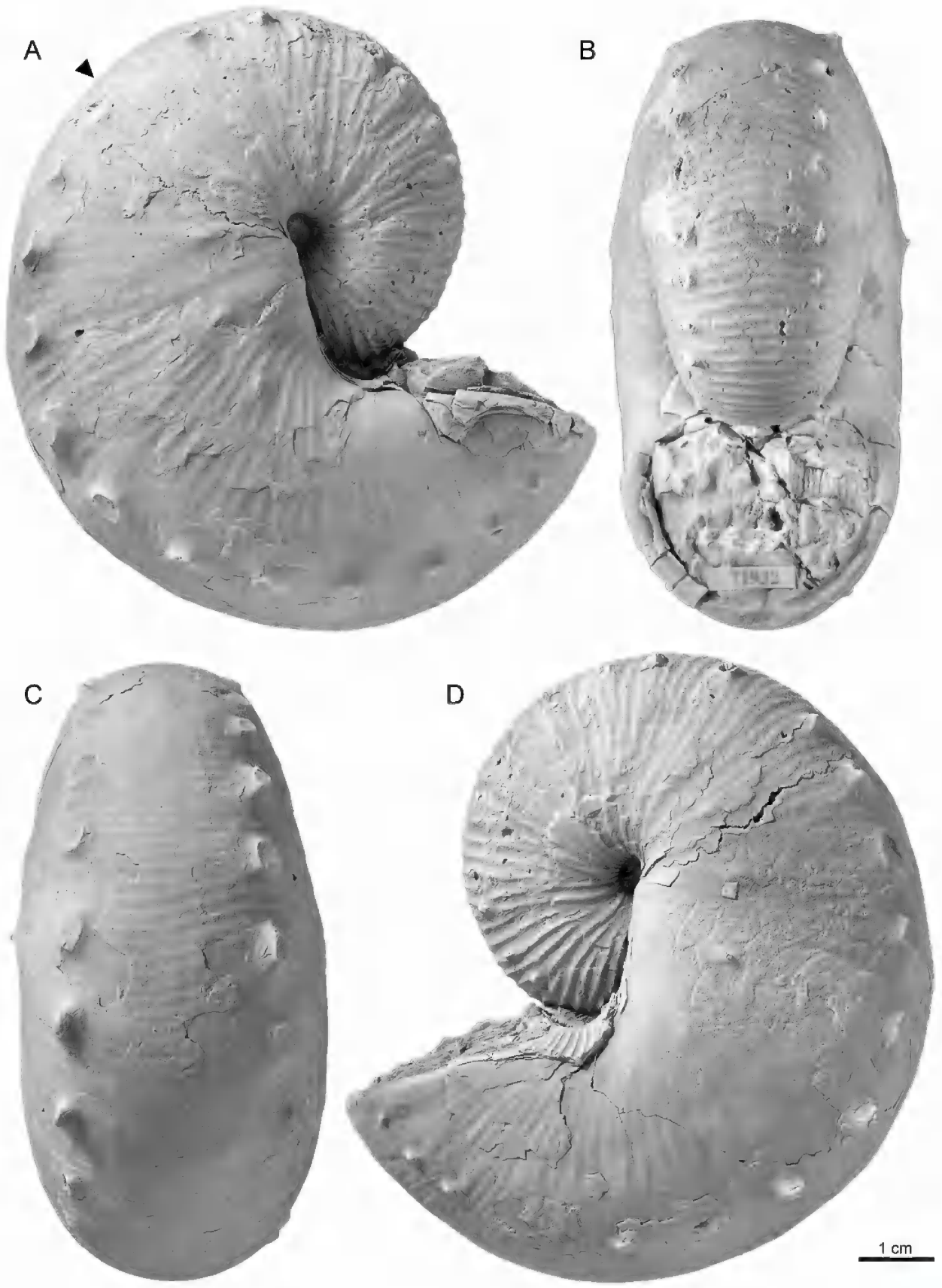

FIGURE 62. Hoploscaphites peterseni, macroconch. A-D. AMNH 71932, AMNH loc. 3921, Baculites baculus or lower B. grandis Zone, Pierre Shale, Cedar Creek Anticline, east-central Montana. A, Right lateral; B, apertural; C, ventral; D, left lateral. Arrow indicates the base of the body chamber. 

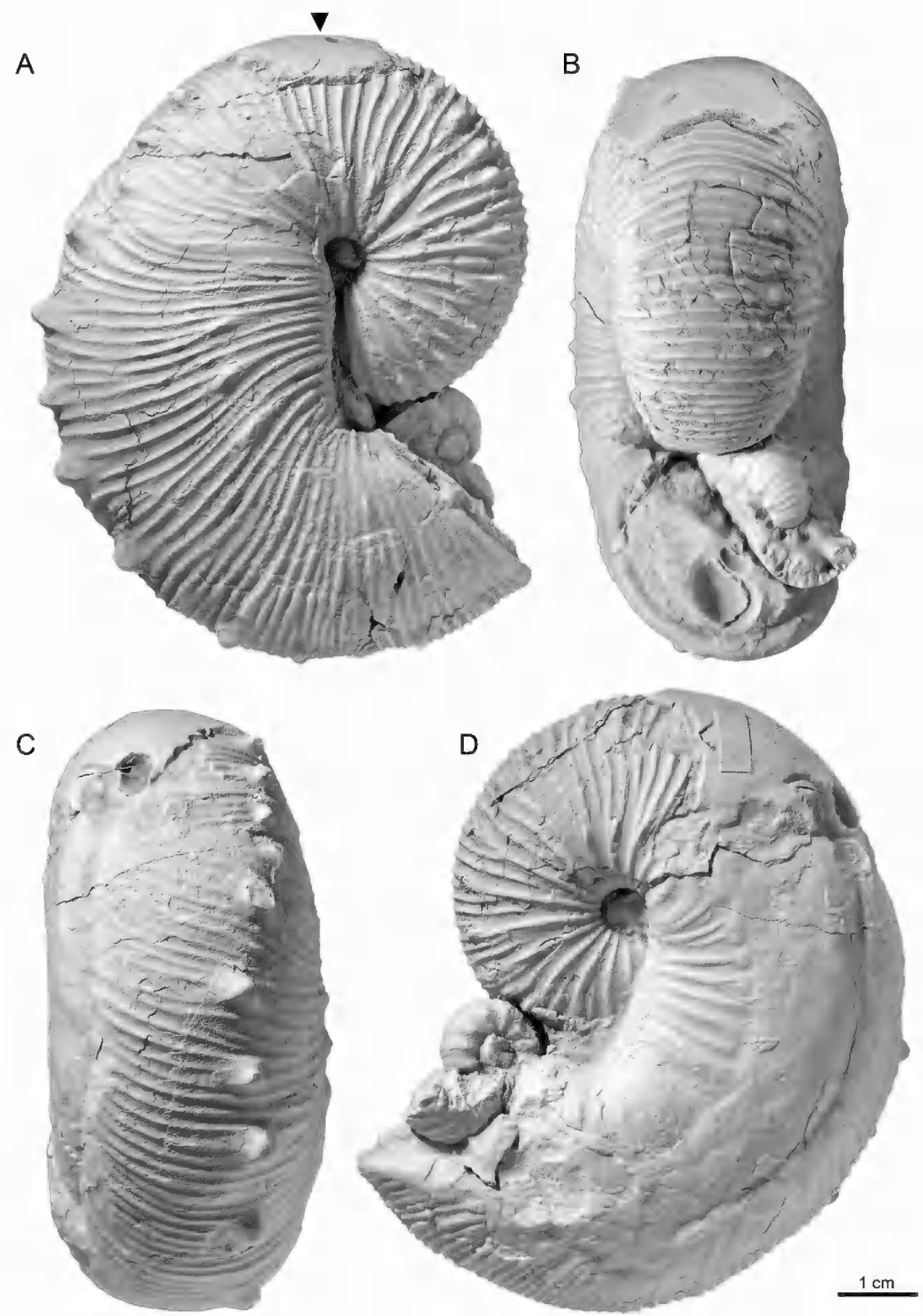

FIGURE 63. Hoploscaphites peterseni, macroconch. A-D. AMNH 135993, coarsely ribbed specimen, AMNH loc. 3921, lower Baculites baculus Zone, Pierre Shale, Cedar Creek Anticline, east-central Montana. A, Right lateral; B, apertural; C, ventral; D, left lateral. Note the longitudinal furrow resulting from a sublethal injury. Arrow indicates the approximate base of the body chamber. 

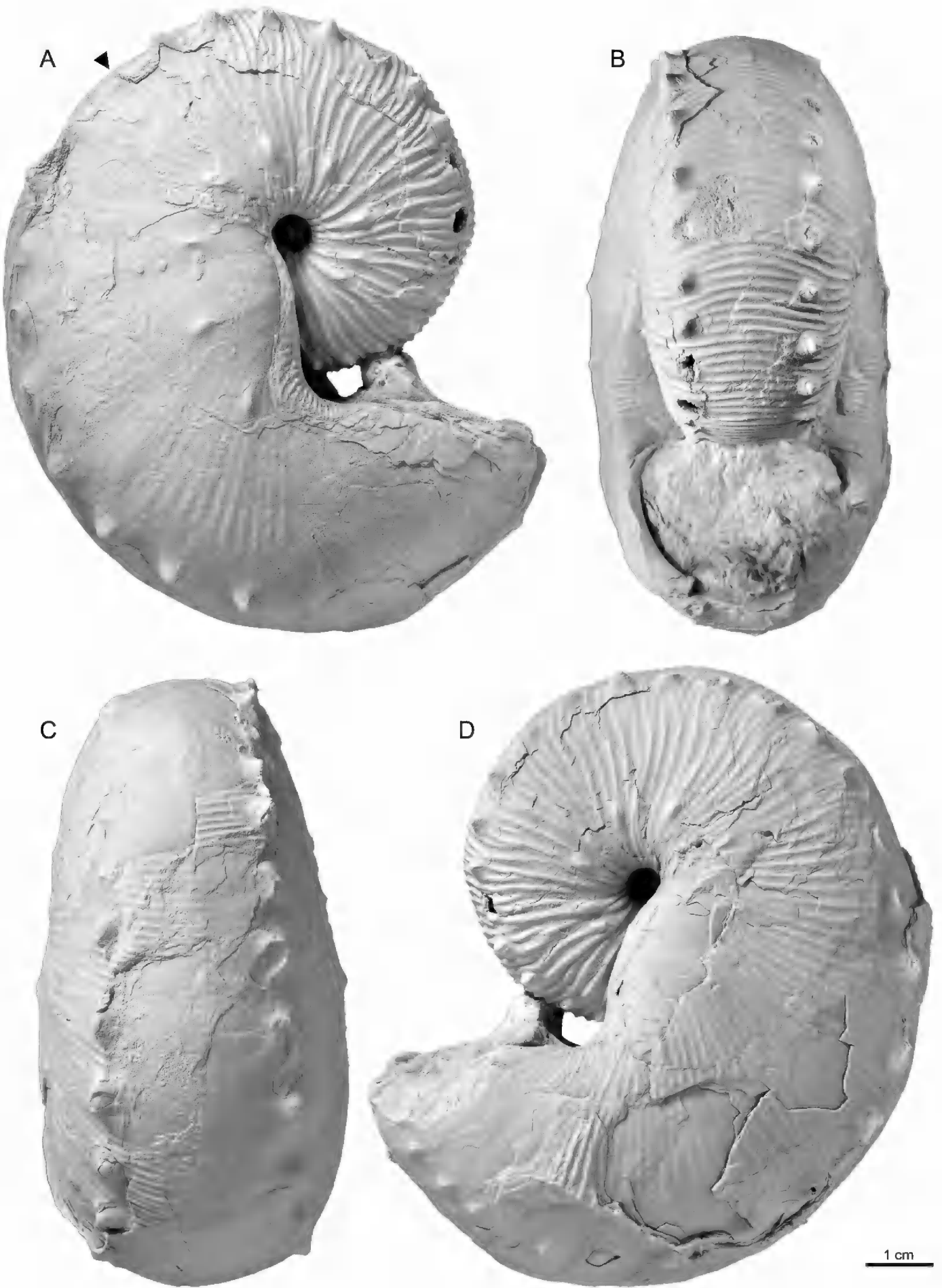

FIGURE 64. Hoploscaphites peterseni, macroconch. A-D. SDSM 149991, Baculites baculus or lower B. grandis Zone, Pierre Shale, Dawson County, Montana. A, Right lateral; B, apertural; C, ventral; D, left lateral. Arrow indicates the base of the body chamber. 

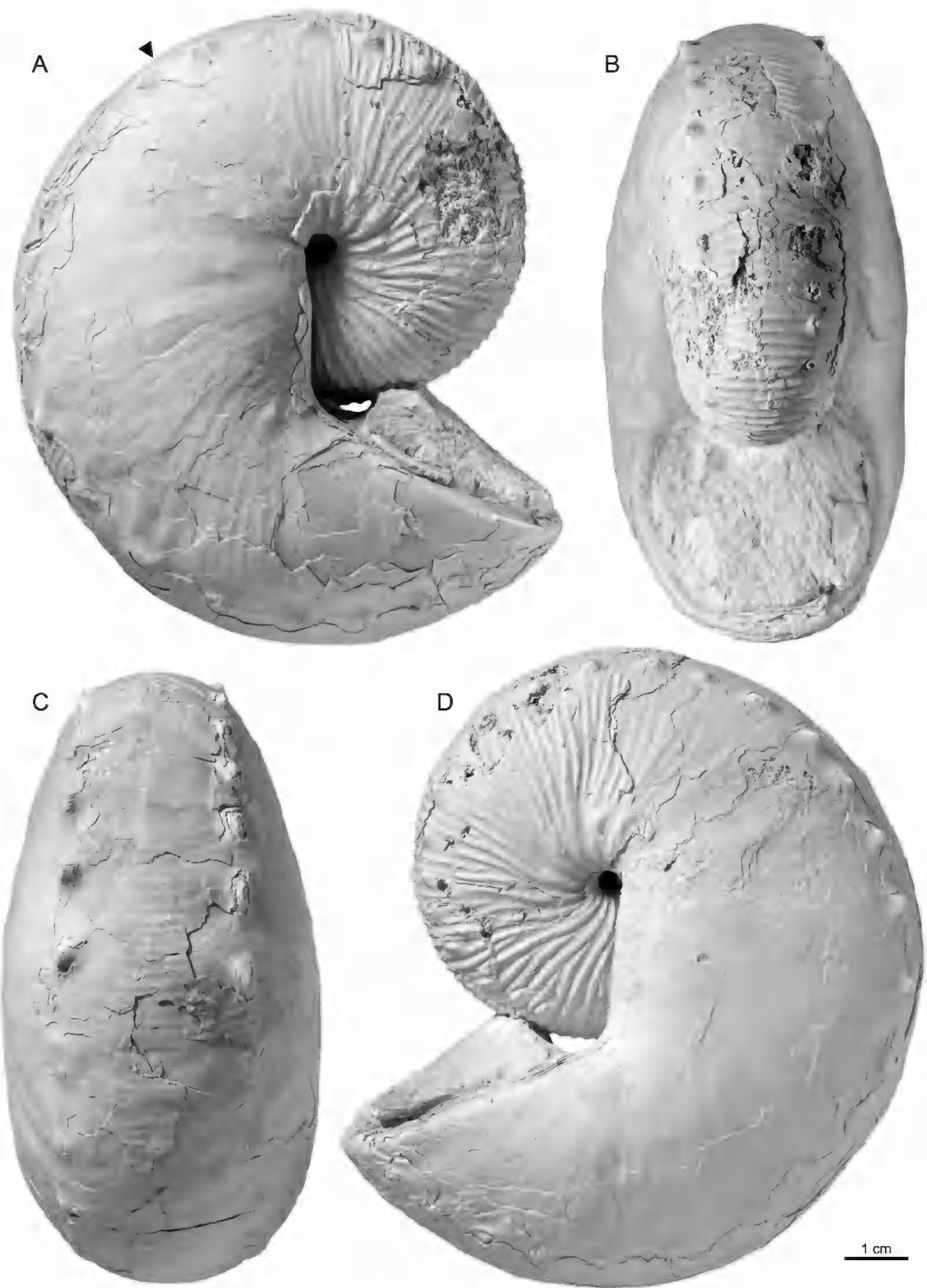

FIGURE 65. Hoploscaphites peterseni, macroconch. A-D. BHI 4128, probably Baculites eliasi Zone, Bearpaw Shale, Valley County, Montana. A, Right lateral; B, apertural; C, ventral; D, left lateral. Arrow indicates the base of the body chamber. 


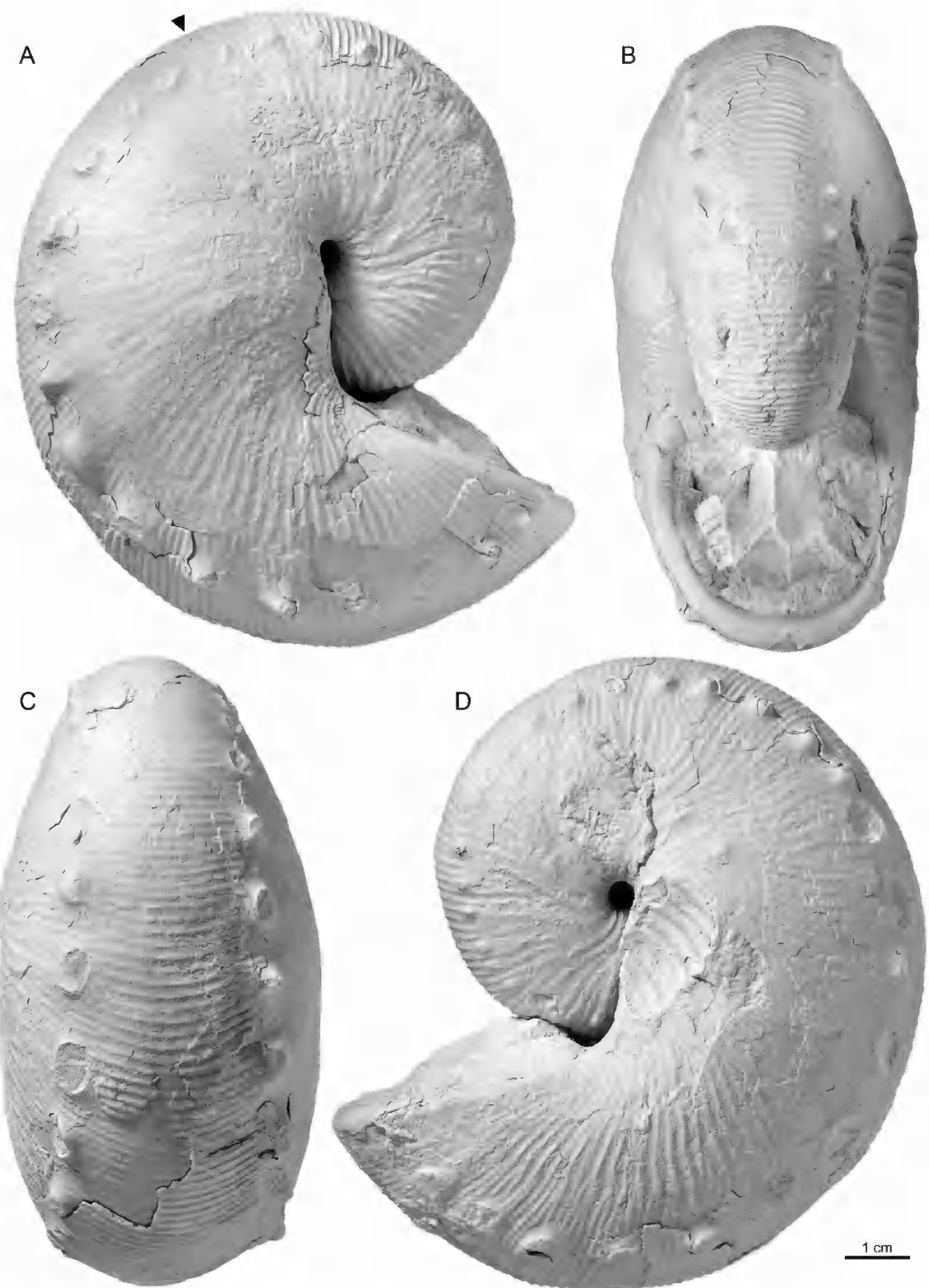

FIGURE 66. Hoploscaphites peterseni, macroconch. A-D. ANSP IP 33699, locality unknown, but probably from the Pierre Shale, Cedar Creek Anticline, east-central Montana. A, Right lateral; B, apertural; C, ventral; $\mathrm{D}$, left lateral. Arrow indicates the base of the body chamber. 


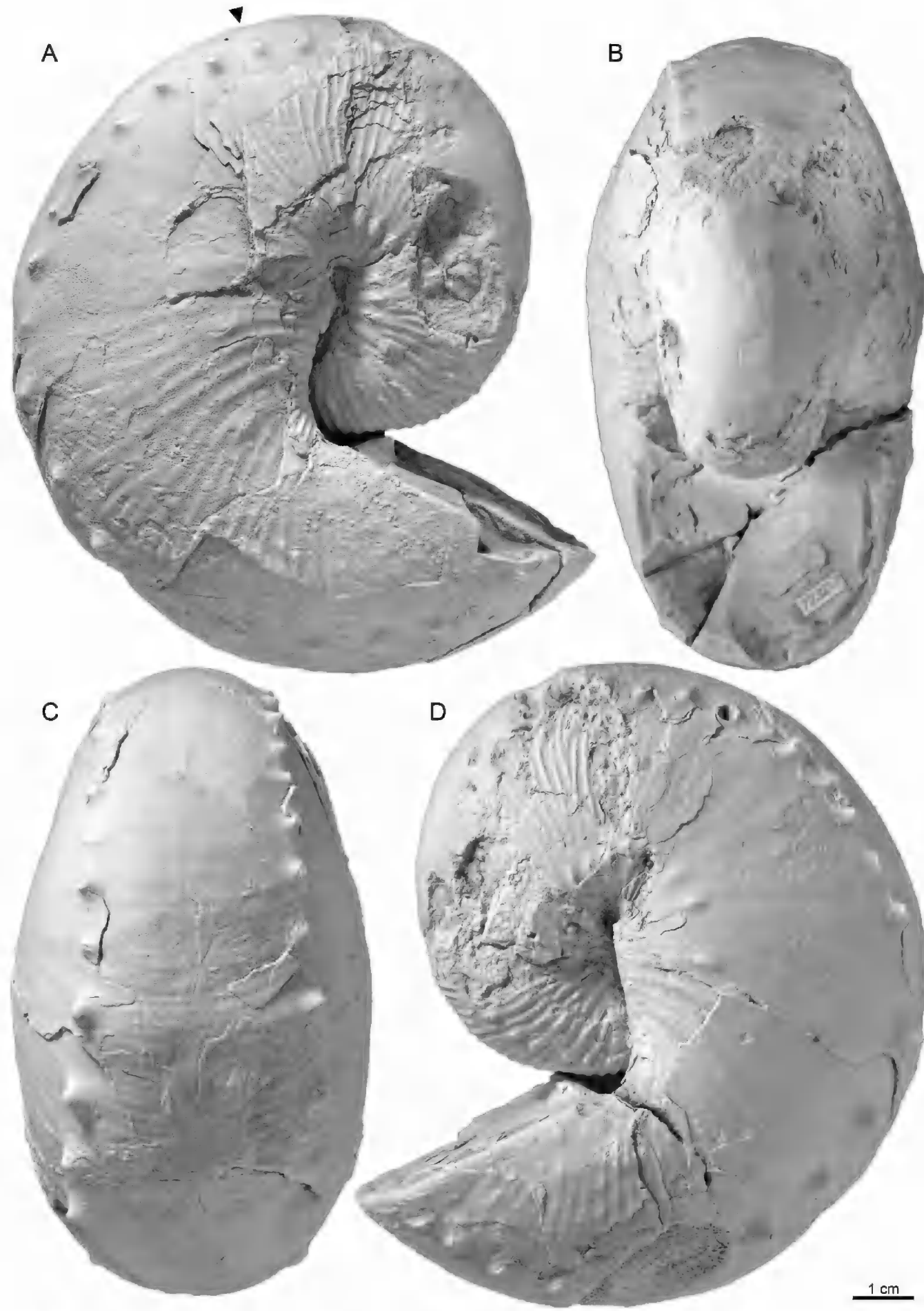

FIGURE 67. Hoploscaphites peterseni, macroconch, paratype. A-D. USNM 723217, USGS loc. 23399, Baculites eliasi zone, Bearpaw Shale, Valley County, Montana. A, Right lateral; B, apertural; C, ventral; D, left lateral. Arrow indicates the base of the body chamber. 


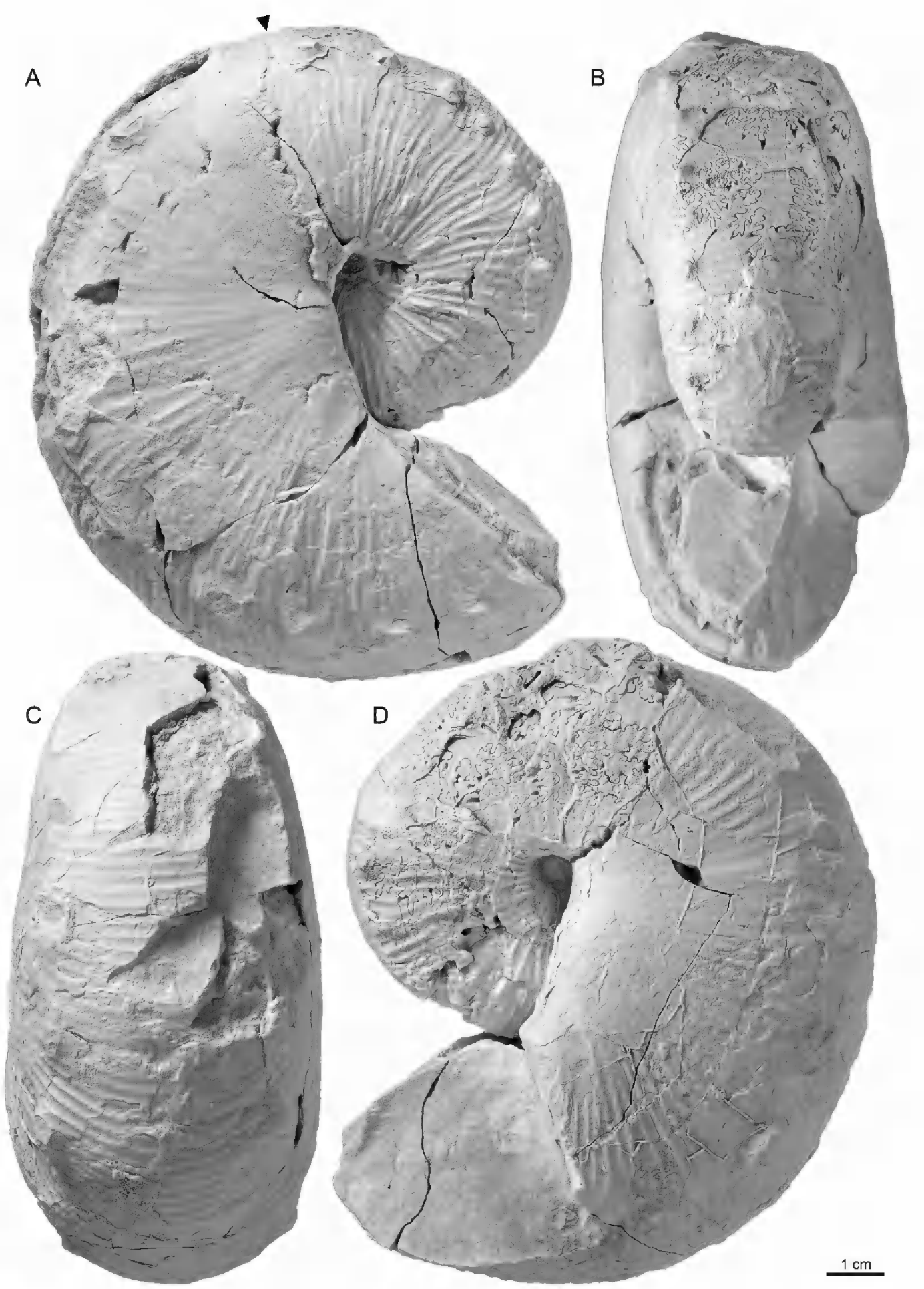

FIGURE 68. Hoploscaphites peterseni, macroconch. A-D. USNM 723220, USGS loc. D1976, lower Baculites baculus Zone, Pierre Shale, Niobrara County, Wyoming. A, Right lateral; B, apertural; C, ventral; D, left lateral. Arrow indicates the base of the body chamber. 

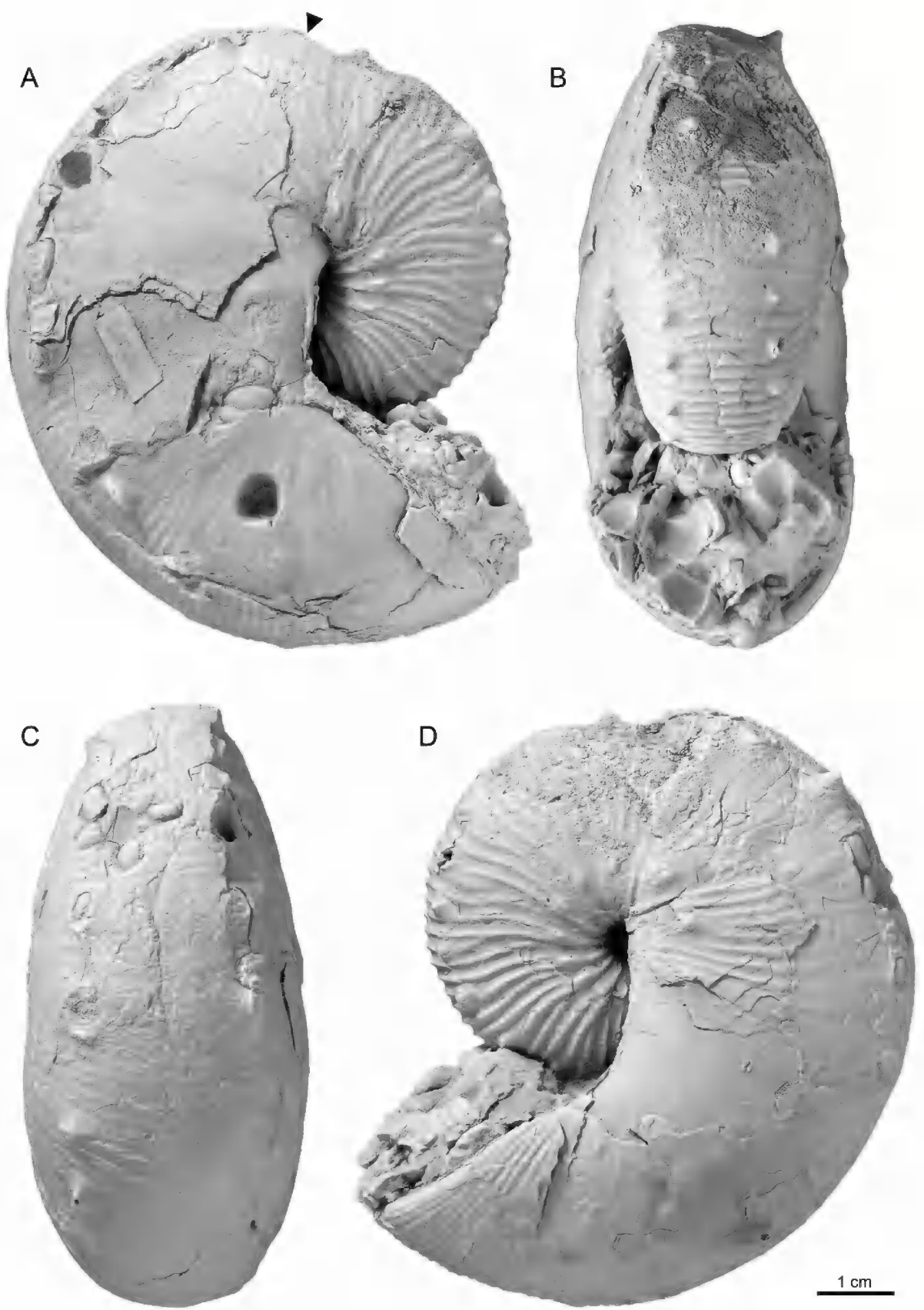

FIGURE 69. Hoploscaphites peterseni, macroconch. A-D. AMNH 108443, Pierre Shale, Cedar Creek Anticline, east-central Montana. A, Right lateral; B, apertural; C, ventral; D, left lateral. Arrow indicates the base of the body chamber. 

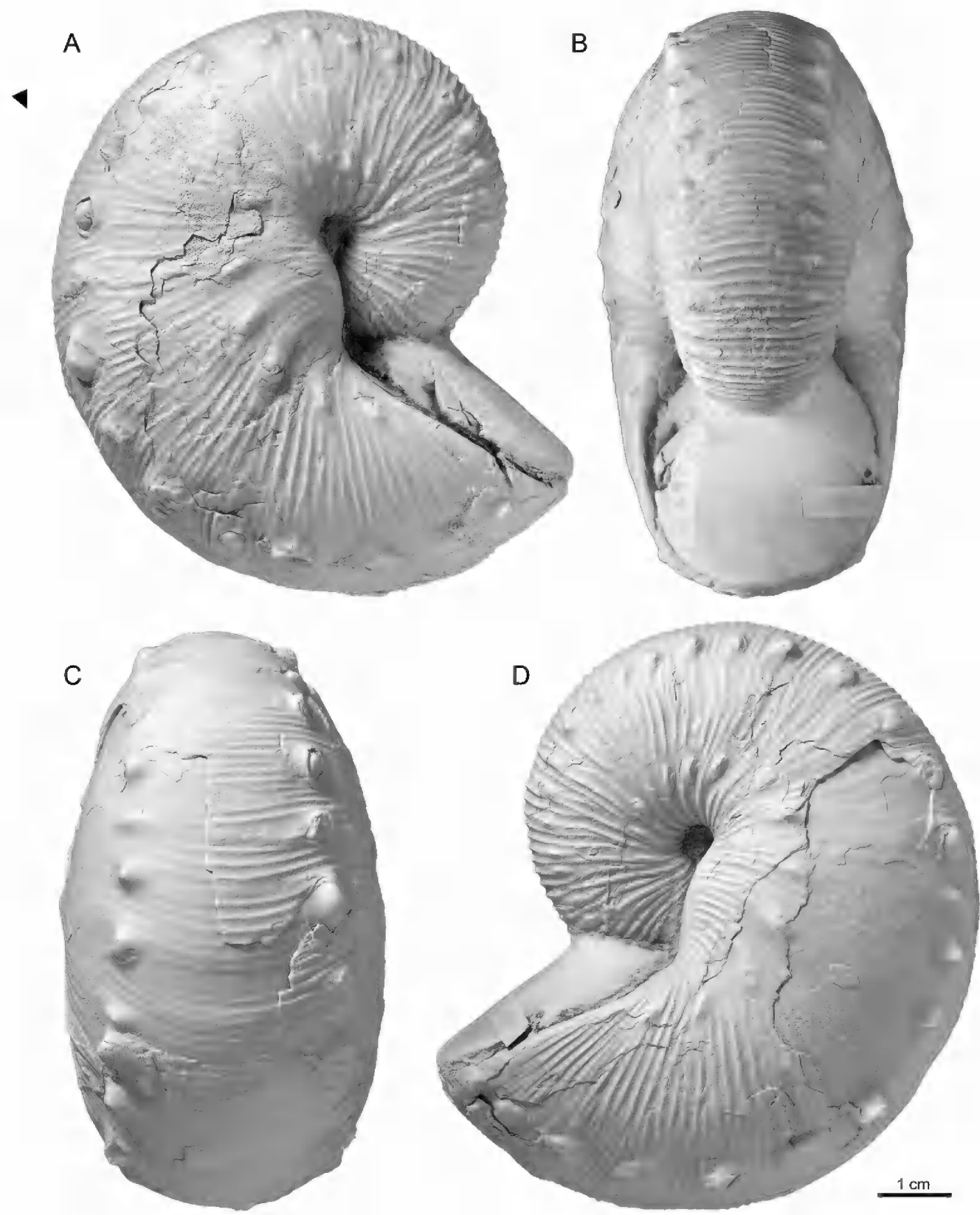

FIGURE 70. Hoploscaphites peterseni, macroconch. A-D. AMNH 105906, paratype, robust specimen, AMNH loc. 3921, lower Baculites baculus Zone, Pierre Shale, Cedar Creek Anticline, east-central Montana. A, Right lateral; B, apertural; C, ventral; D, left lateral. Arrow indicates the base of the body chamber. 

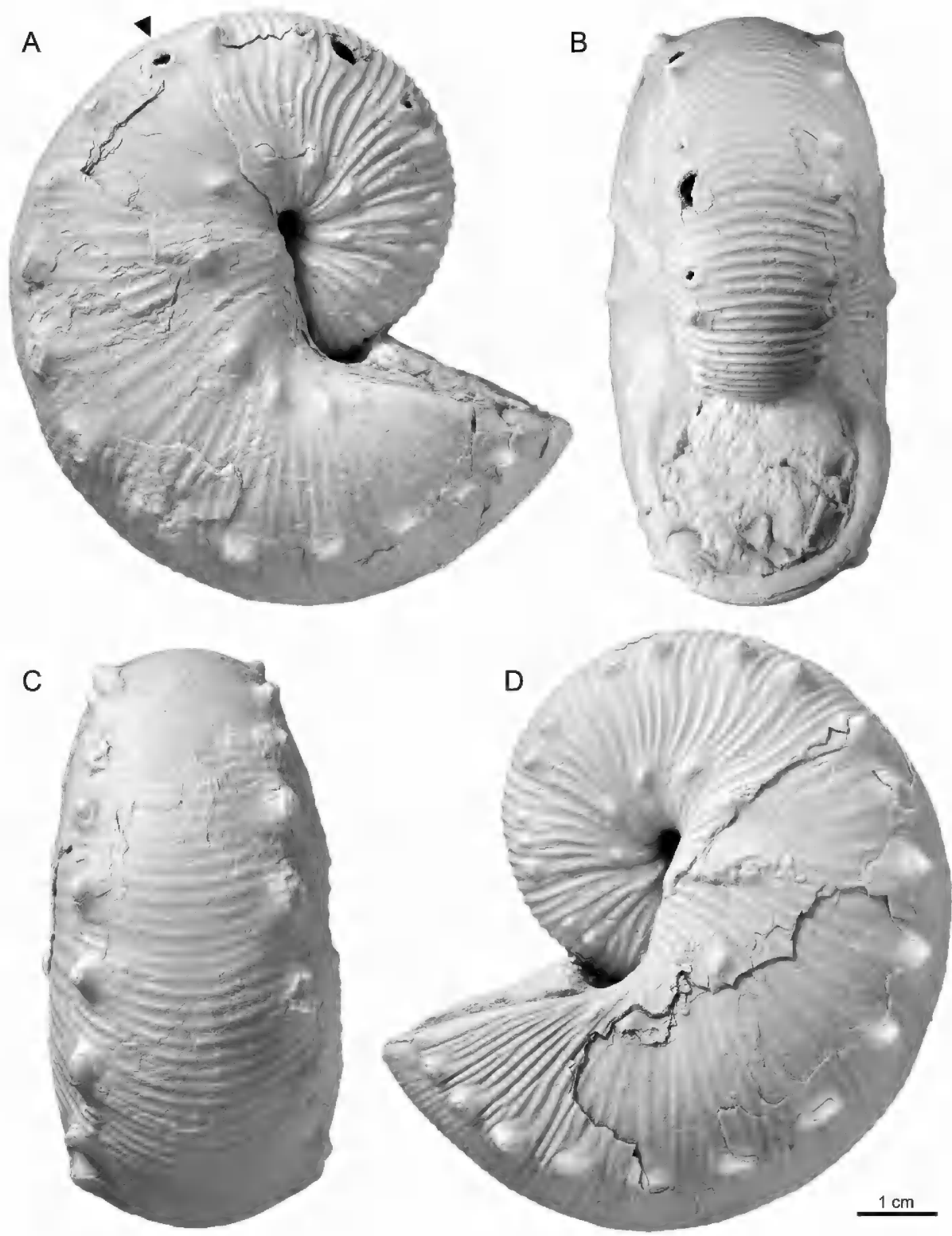

FIGURE 71. Hoploscaphites peterseni, macroconch. A-D. SDSM 149990, Baculites baculus or lower B. grandis Zone, Pierre Shale, Dawson County, Montana. A, Right lateral; B, apertural; C, ventral; D, left lateral. Arrow indicates the base of the body chamber. 

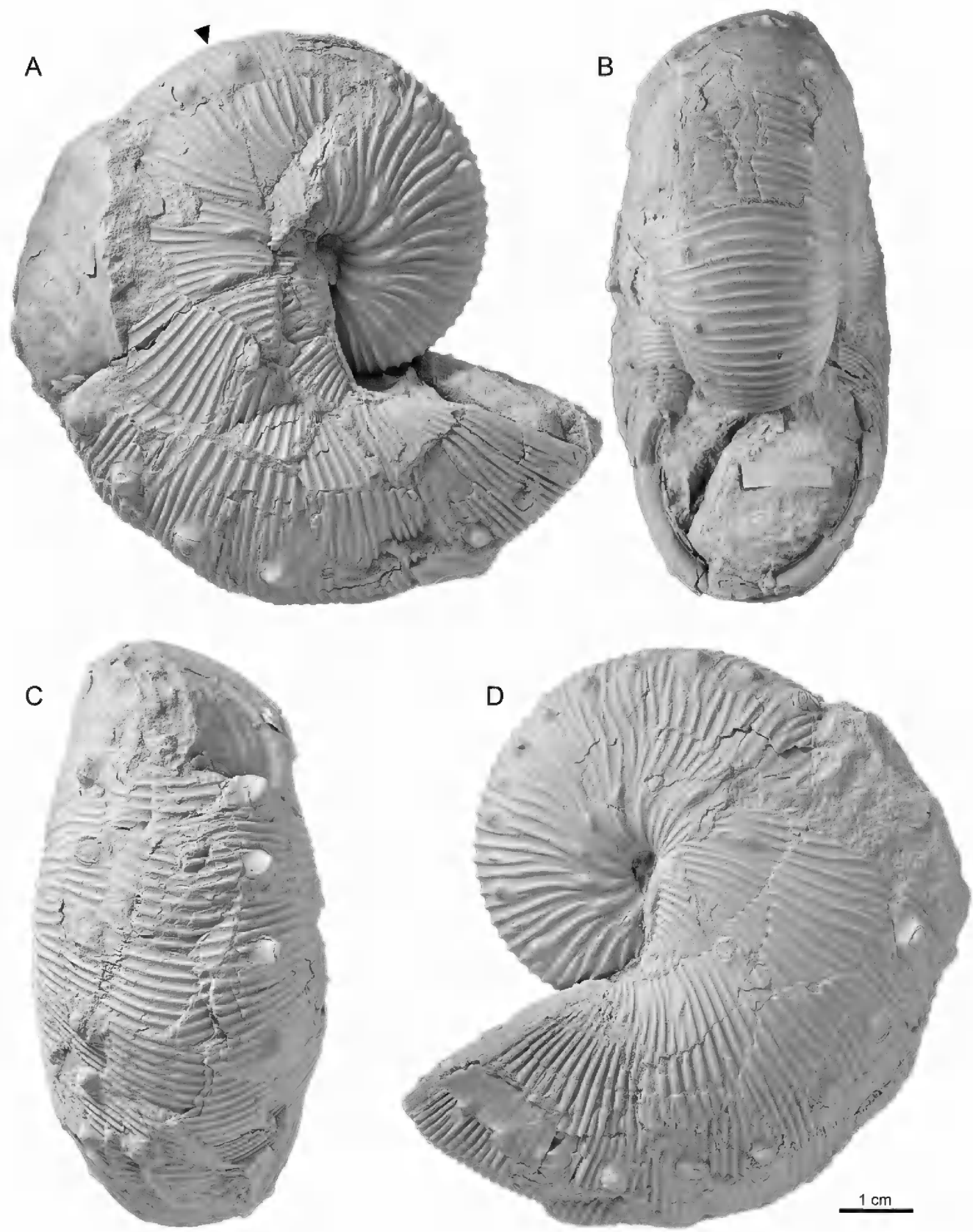

FIGURE 72. Hoploscaphites peterseni, macroconch. A-D. AMNH 71935, AMNH loc. 3921, Baculites baculus or lower B. grandis Zone, Pierre Shale, Cedar Creek Anticline, east-central Montana. A, Right lateral; B, apertural; C, ventral; D, left lateral. Note the lethal injury on the adapical end of the body chamber (missing piece of shell). Arrow indicates the approximate base of the body chamber. 

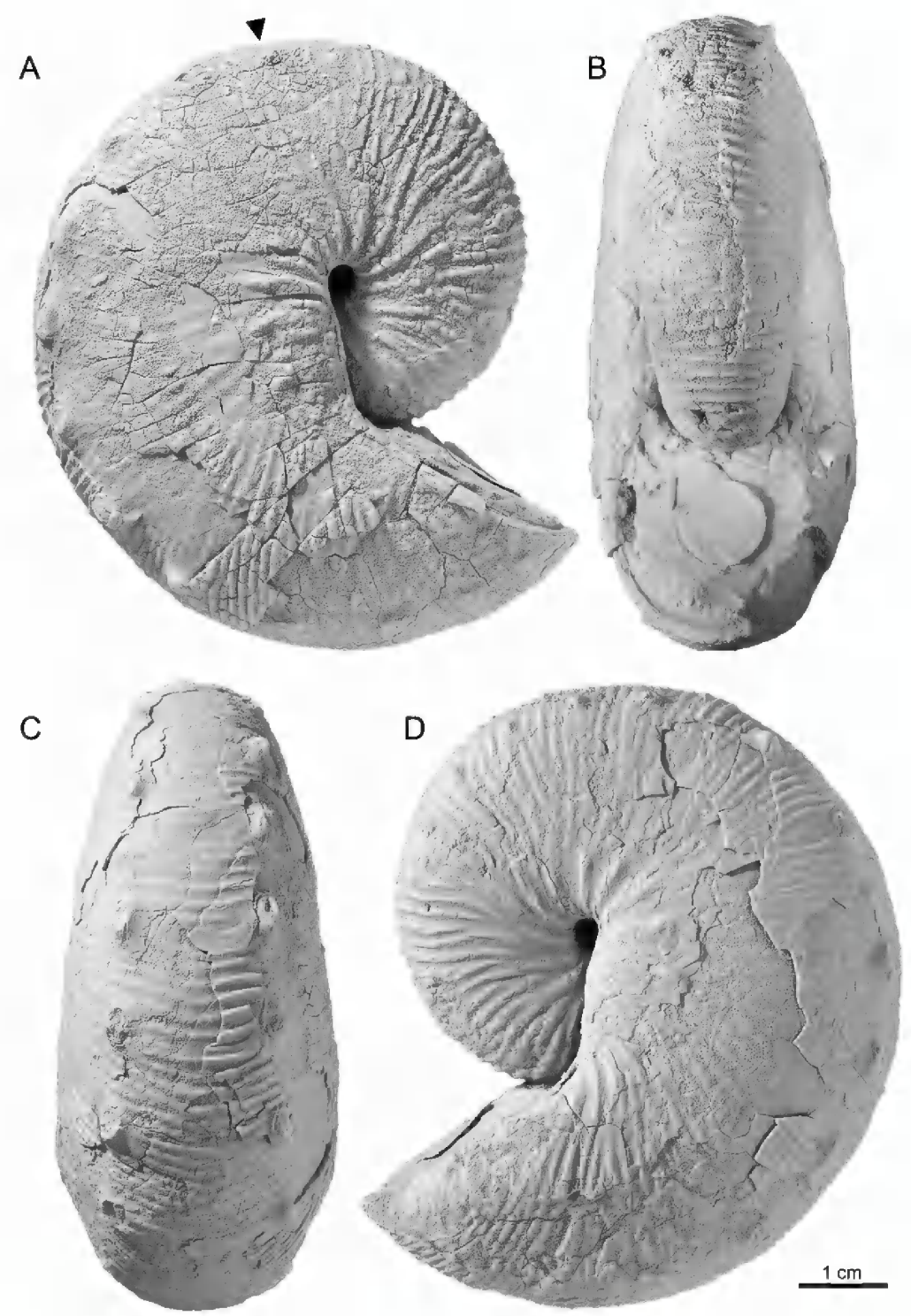

FIGURE 73. Hoploscaphites peterseni, macroconch. A-D. USNM 723221, USGS loc. 7215, Pierre Shale, Weston County, Wyoming. A, Right lateral; B, apertural; C, ventral; D, left lateral. Arrow indicates the approximate base of the body chamber. 

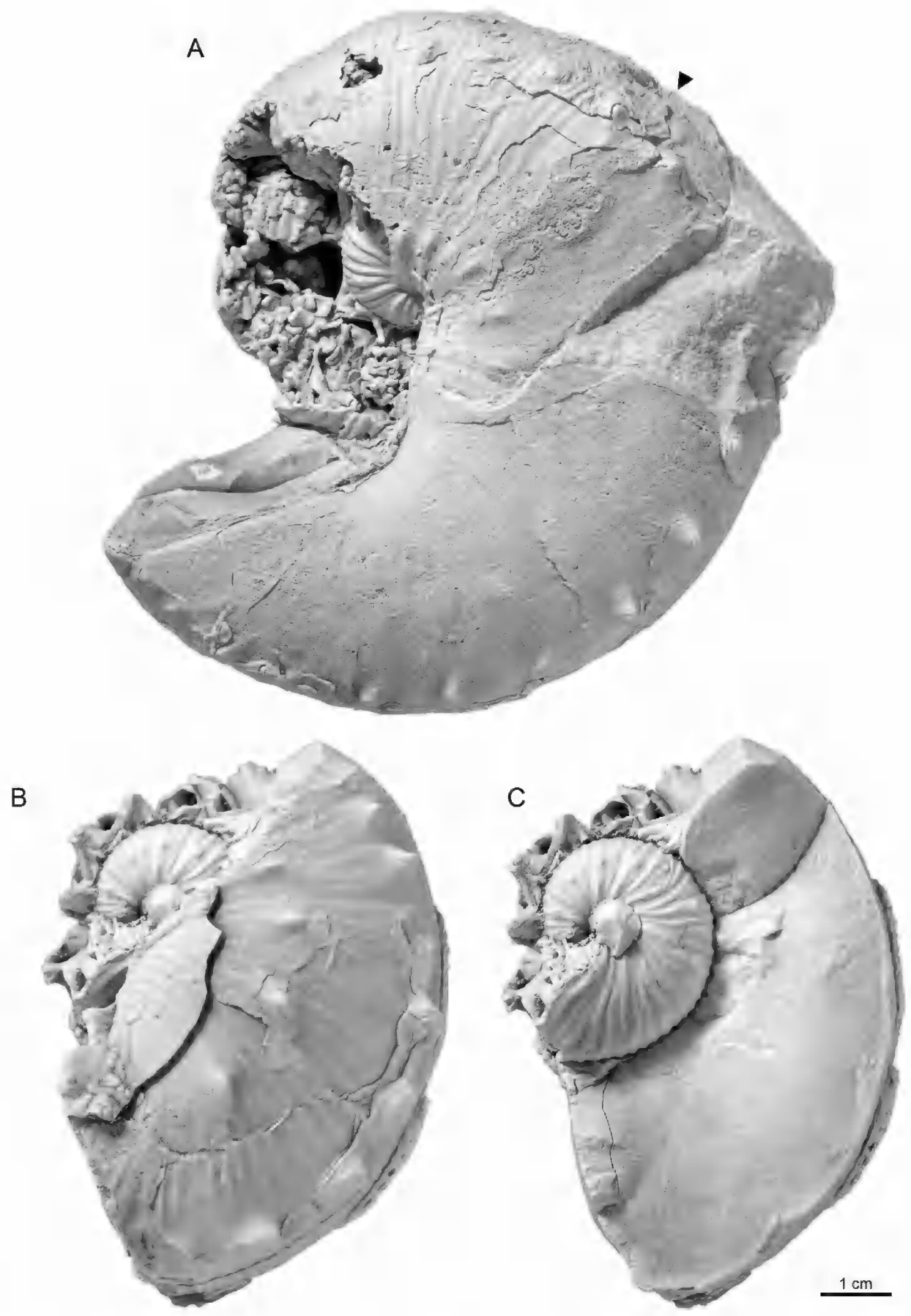

FIGURE 74. Hoploscaphites peterseni, macroconchs. A. USNM 723231, left lateral, USGS loc. 22142, Baculites eliasi Zone, Bearpaw Shale, Valley County, Montana. The coarse ornamentation on the inner whorls is visible. Arrow indicates the base of the body chamber. B, C. AMNH 73031, left lateral, fragment with the body chamber attached (B) and removed (C), B. baculus Zone, AMNH loc. 3921, Pierre Shale, Cedar Creek Anticline, east-central Montana. The ornamentation on the inner whorls consists of widely spaced ribs and ventrolateral tubercles. 

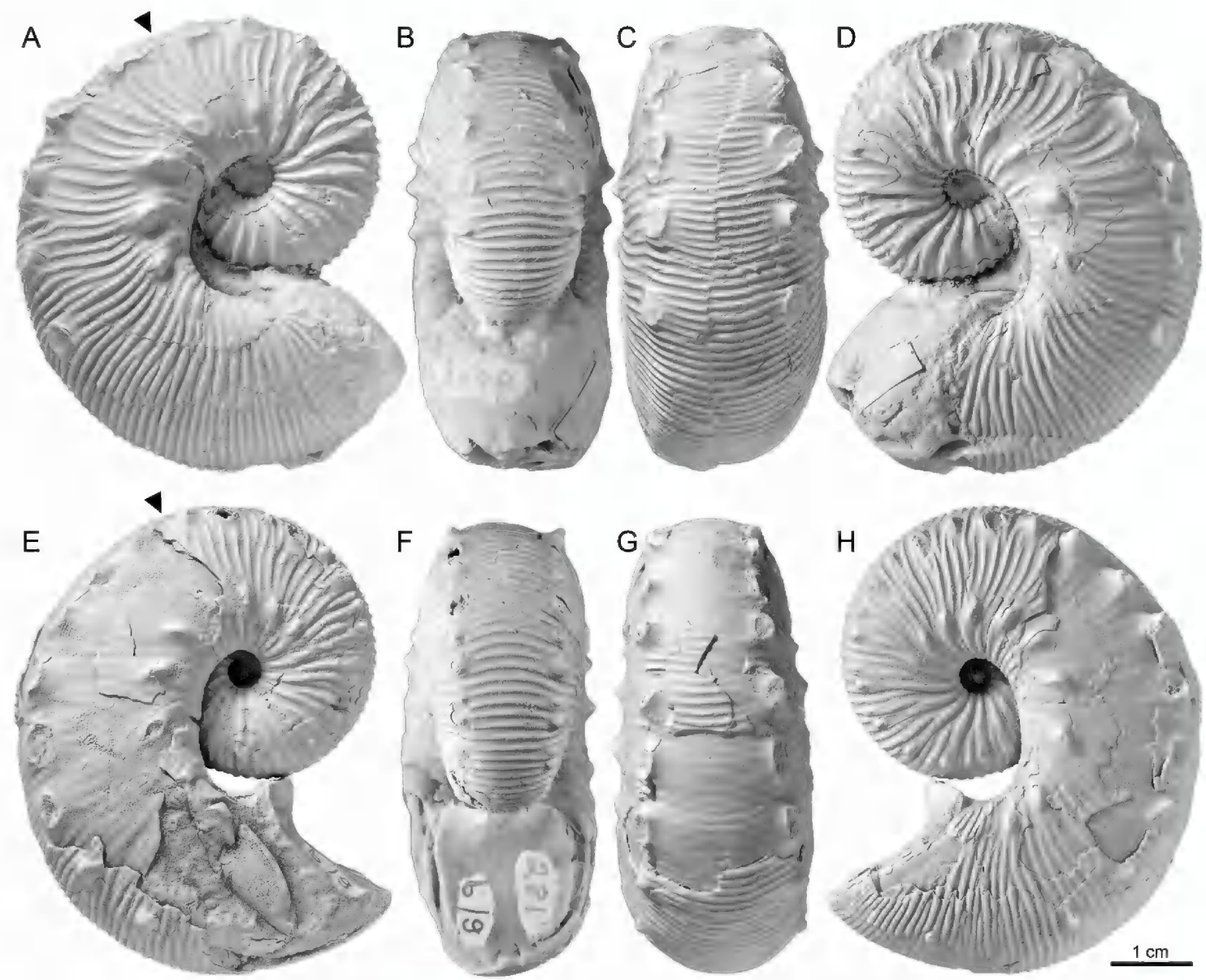

FIGURE 75. Hoploscaphites peterseni, microconchs. A-D. AMNH 105901, paratype, AMNH loc. 3921, upper Baculites baculus Zone, Pierre Shale, Cedar Creek Anticline, east-central Montana. A, Right lateral; B, apertural; C, ventral; D, left lateral. E-H. BHI 4129, Baculites baculus or lower B. grandis Zone, Pierre Shale, Cedar Creek Anticline, east-central Montana. E, Right lateral; F, apertural; G, ventral; H, left lateral. Arrow indicates the base of the body chamber. 

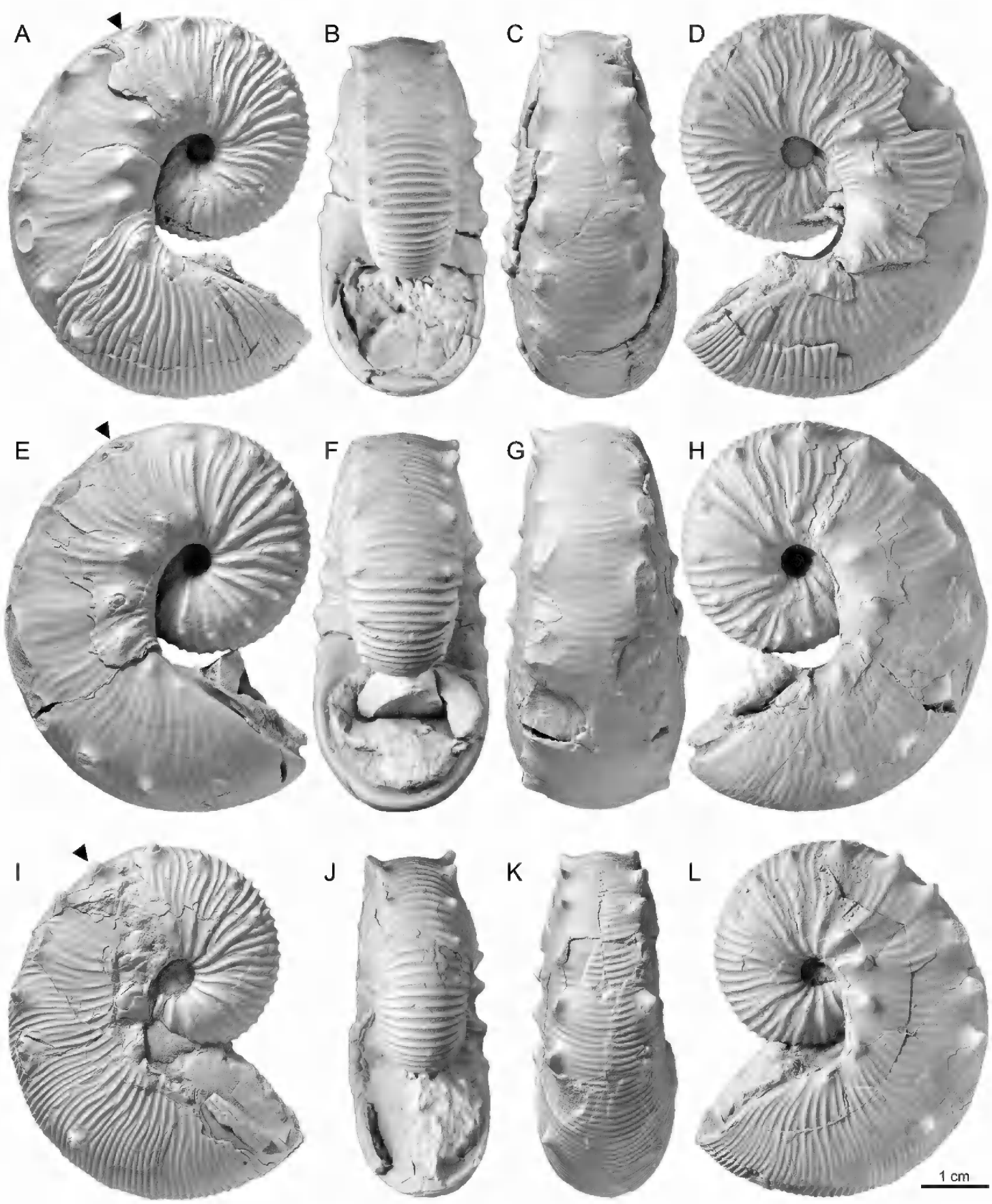

FIGURE 76. Hoploscaphites peterseni, microconchs. A-D. AMNH 135087, AMNH loc. 3921, Baculites baculus or lower B. grandis Zone, Pierre Shale, Cedar Creek Anticline, east-central Montana. A, Right lateral; B, apertural; C, ventral; D, left lateral. E-H. AMNH 77597, AMNH loc. 3246, Baculites baculus or lower B. grandis Zone, Pierre Shale, southwest of Wibaux (= Mingusville), Wibaux County, Montana. E, Right lateral; F, apertural; G, ventral; H, left lateral. I-L. AMNH 134704, Pierre Shale, Cedar Creek Anticline, east-central Montana. I, Right lateral; J, apertural; K, ventral; L, left lateral. Arrow indicates the base of the body chamber. 

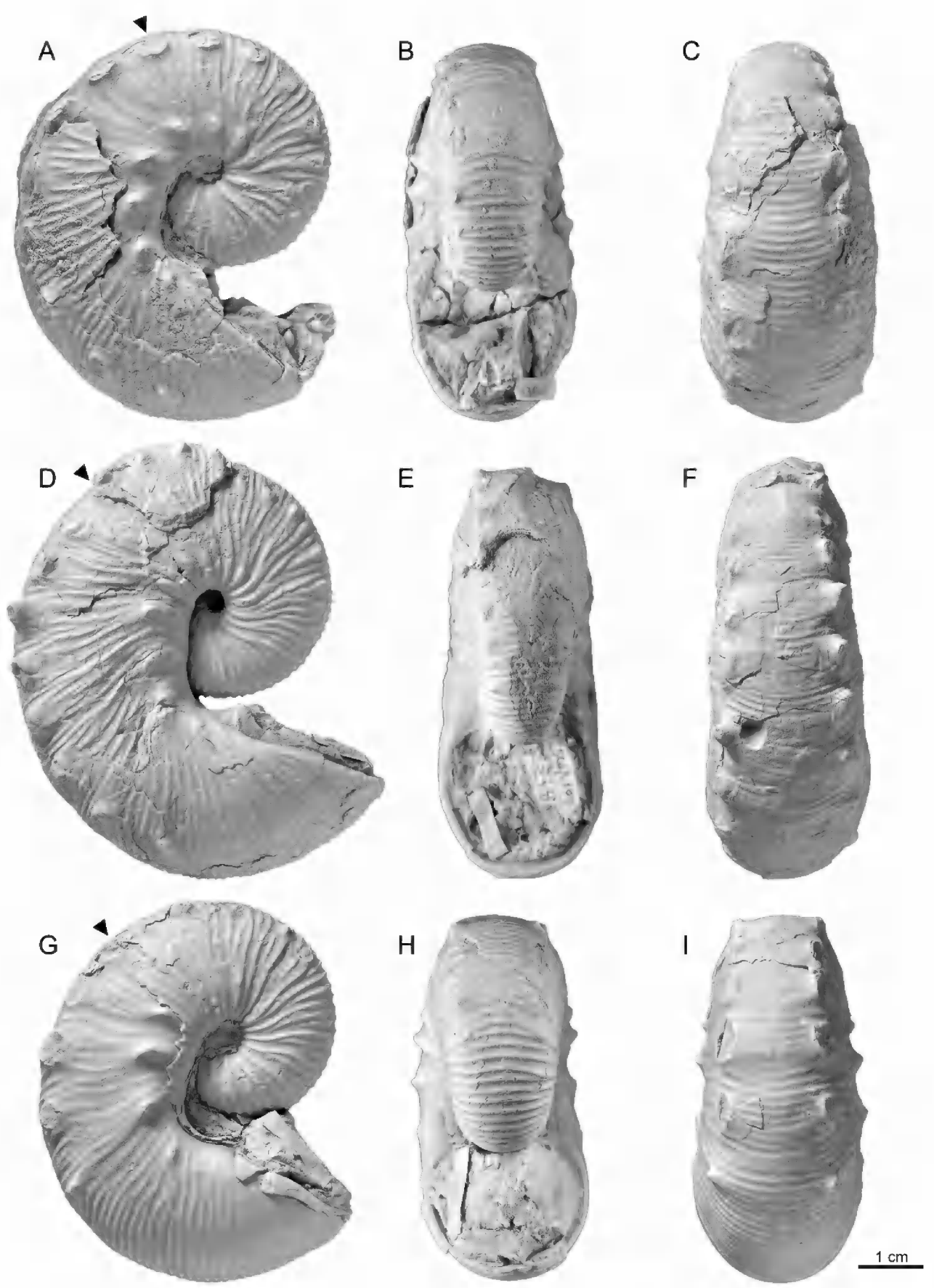

FIGURE 77. Hoploscaphites peterseni, microconchs. A-C. AMNH 76304, AMNH loc. 3921, upper Baculites baculus Zone, Pierre Shale, Cedar Creek Anticline, east-central Montana. A, Right lateral; B, apertural; C, ventral. D-F. AMNH 76402, AMNH loc. 3921, Baculites baculus or lower B. grandis Zone, Pierre Shale, Cedar Creek Anticline, east-central Montana. D, Right lateral; E, apertural; F, ventral. G-I. AMNH 76400, paratype, AMNH loc. 3921, Baculites baculus or lower B. grandis Zone, Pierre Shale, Cedar Creek Anticline, east-central Montana G, Right lateral; H, apertural; I, ventral. Arrow indicates the base of the body chamber. 

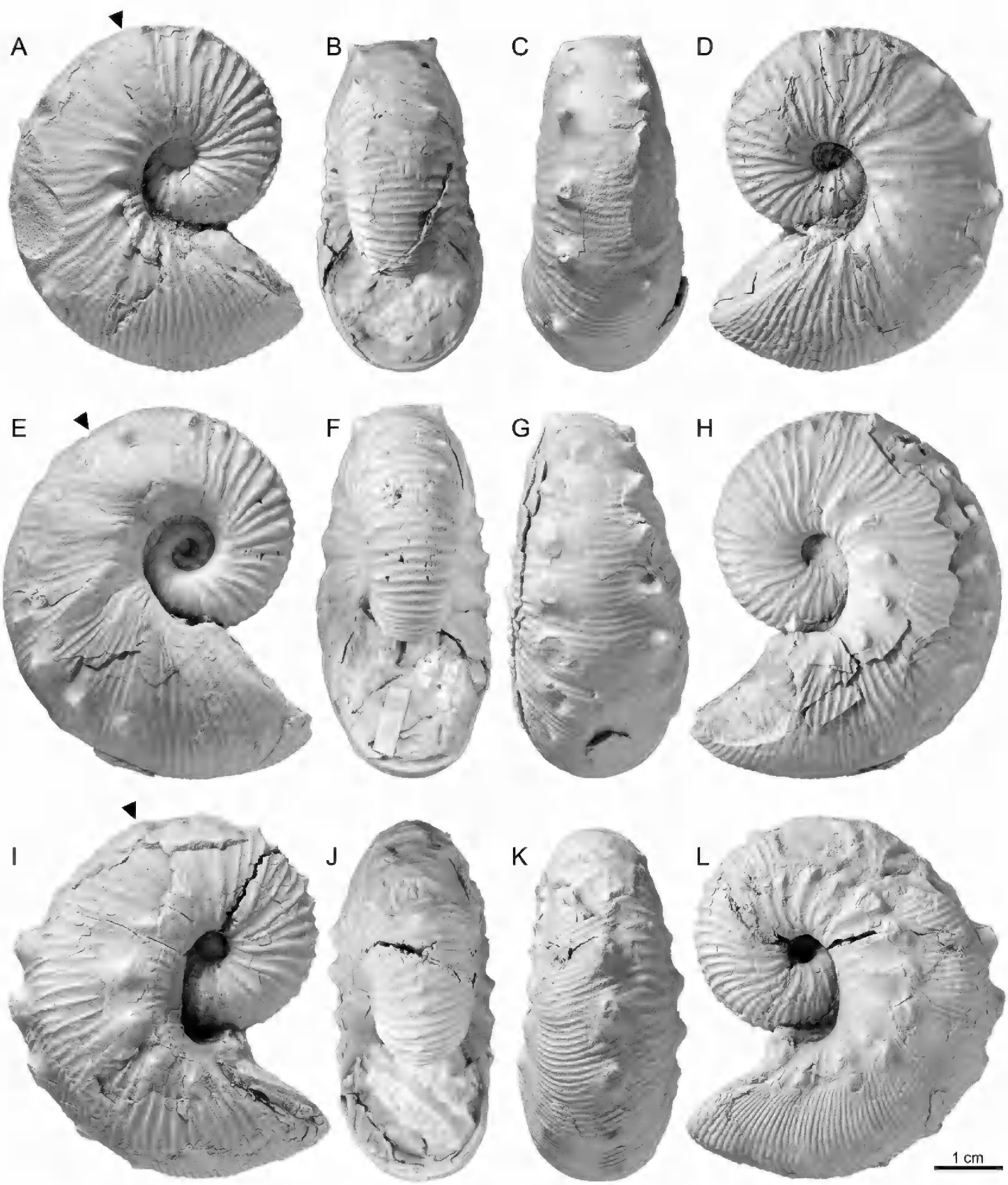

FIGURE 78. Hoploscaphites peterseni, microconchs. A-D. AMNH 135978, AMNH loc. 3921, Baculites baculus or lower B. grandis Zone, Pierre Shale, Cedar Creek Anticline, east-central Montana. A, Right lateral; B, apertural; C, ventral; D, left lateral. E-H. AMNH 76311, AMNH loc. 3921, Baculites baculus or lower B. grandis Zone, Pierre Shale, Cedar Creek Anticline, east-central Montana. Note the difference in umbilical diameter between the left and right sides due to a growth deformity. E, Right lateral; F, apertural; G, ventral; H, left lateral. I-L. BHI 4893, Pierre Shale, Cedar Creek Anticline, east-central Montana. I, Right lateral; J, apertural; $\mathbf{K}$, ventral; $\mathbf{L}$, left lateral. The two rows of ventrolateral tubercles have merged into a single row of midventral tubercles due to a sublethal injury. Arrow indicates the base of the body chamber. 
Ventrolateral tubercles are usually present starting at the point of exposure, as in BHI 4129 (fig. 75E-H). However, we have observed many exceptions to this rule, as in AMNH 76400 (fig. $77 \mathrm{G}-\mathrm{I})$, in which tubercles only first appear on the adoral end of the phragmocone. As a result, the number of tubercles on the phragmocone in the latter specimen is lower than that in the former specimen (5 vs. 18). Tubercles occur at $7 / 8$ whorl height and are usually paired on opposite sides of the venter. Although as noted above, one rib usually joins a ventrolateral tubercle dorsally, tubercles sometimes occur in the interspaces between ribs. In many specimens, the tubercles are grouped in clusters. For example, in BHI 4129 (fig. 75E$\mathrm{H})$, clusters of closely spaced tubercles (2-3.5 mm between consecutive tubercles) alternate with clusters of more widely spaced tubercles (4-4.5 $\mathrm{mm}$ between consecutive tubercles).

Ventrolateral tubercles continue onto the body chamber and usually terminate at the point of recurvature. They are evenly and moderately widely spaced. The maximum distance between consecutive tubercles ranges from 10 to $12 \mathrm{~mm}$. They develop into small clavi at midshaft with a maximum height of $2 \mathrm{~mm}$. The number of tubercles on the body chamber in BHI 4129 (fig. 75E-H) and AMNH 76400 (fig. 77G-I) is 10 and 5, respectively, so that the total number of ventrolateral tubercles on the exposed shell of these specimens is 28 and 10, respectively. Tubercles are usually paired on opposite sides of the venter. In BHI 4893 (fig. 78I$\mathrm{L})$, the rows of ventrolateral tubercles on opposite sides of the venter are reduced to a single midventral row due to a non-lethal injury in early ontogeny. After reaching maturity, the specimen was attacked again, this time fatally, as indicated by a missing chunk of shell from the adapical part of the body chamber.

Discussion: Hoploscaphites peterseni, n. sp., most closely resembles $H$. crassus. Both species are characterized by numerous, closely spaced ventrolateral tubercles that usually extend to the aperture. In addition, both species exhibit long, narrow, and closely spaced ribs on the flanks of the adoral part of the phragmocone. The two species differ in the degree of whorl inflation. In $H$. peterseni, the whorl section of the shaft is compressed subovoid with broadly rounded flanks and venter whereas in $H$. crassus, the whorl section of the shaft is depressed reniform with well rounded flanks and broadly rounded venter. Hoploscaphites peterseni also closely resembles $H$. macer. The principal differences between these two species are that the ribs on the adoral part of the phragmocone are much finer and more closely spaced in $H$. perterseni than in H. macer. The two species also differ in the degree of whorl inflation, with $H$. peterseni more depressed than $H$. macer. Macroconchs of $H$. peterseni bear a vague resemblance to those of the geologically older species $H$. brevis (Meek, 1876) because the umbilicolateral tubercles on the shaft are arranged in a semicircle in both species. However, the whorl section is more inflated and the ribs on the adapical part of the phragmocone are coarser and more widely spaced in $H$. peterseni than in $H$. brevis.

OCCURRence: Hoploscaphites peterseni ranges from the Baculites eliasi Zone to the lower part of the B. grandis Zone. It is especially abundant in the scaphite and septarian concretionary horizons in the lower part of the B. baculus Zone of the Pierre Shale on the Cedar Creek Anticline in east-central Montana. It occurs in the same zone in the Pierre Shale in Niobrara and Weston counties, Wyoming. It is also present in the $B$. eliasi Zone of the Bearpaw Shale in Valley, Garfield, and McCone counties, Montana.

\section{ACKNOWLEDGMENTS}

At the American Museum of Natural History, we thank Ana Rashkova, Bushra Hussaini, Mary Conway, Kathleen Sarg, and Marion Savas for accessioning material and assigning AMNH numbers, Mary Knight for editing the manuscript for publication, and Stephen Thurston for photographing specimens and preparing figures. We thank the landowners Donley and Nancy Darnell and Bobbie Blankenship for permission to collect on their property. Many students, colleagues, and 
family members have helped us collect in the field and interpret the results, and we wish to express our thanks to Jamie Brezina, J. Kirk Cochran, Matthew P. Garb, Kate F. Grier, Isabella Kruta, Ekaterina Larina, Luke Larson, Corinne Myers, Jack Petersen, Dean G. Grier, Kristin Polizzotto, Remy Rovelli, Al Rowe, Joshua Slattery, Kazushige Tanabe, James Witts, Lee Herman, and Benjamin Laabs. We thank many individuals, who at our request, tracked down locality information, assigned numbers, and facilitated loans of specimens in their collections: K.C. McKinney (USGS), Susan H. Butts and Jessica Utrup (YPM), Kathy Hollis (USNM), Jocelyn A. Sessa and Katy EstesSmargiassi (ANSP), Lauren Neitzke Adamo and Julia Criscione (RUGM), Scott Lidgard and Paul Mayor (FMNH), and Laurie Anderson (SDSM). Many of the specimens of Hoploscaphites at SDSM were collected by Gale Bishop during the course of his M.S. thesis on the Cedar Creek Anticline. L.T. thanks Annaka Clement for help in making thin sections. J.C. and J.W. Grier thank Donald P. Schwert and Allan C. Ashwerth who introduced them to the Cedar Creek Anticline and the late William A. Cobban who was an active and frequent mentor, including in the field. This research was supported by the N.D. Newell Fund (AMNH), the René M. Vandervelde Research Grant to N.H.L. from the Association of Applied Paleontological Sciences, and personal funds of J.C. and J.W. Grier, T. Linn, and N.L. Larson. The authors are deeply indebted to Matthew P. Garb and Royal H. Mapes for their detailed review of this manuscript, covering stratigraphy and paleontology. Their comments substantially improved the manuscript. This manuscript is dedicated to Robert Parr Whitfield, first Curator of Invertebrate Paleontology at the $\mathrm{AMNH}$ and founder of the AMNH Bulletin series.

\section{REFERENCES}

Atabekian, A.A. 1979. Correlation of the Campanian stage in Kopetdag and Western Europe. In Aspekte der Kreide Europas, International Union of Geological Sciences A6: 511-526. Stuttgart: Schweizerbart.
Bishop, G.A. 1967. Biostratigraphic mapping in the upper Pierre Shale utilizing the cephalopod genus Baculites, Cedar Creek Anticline, Montana. M.S. thesis, Department of Geology, South Dakota School of Mines and Technology, Rapid City, SD, 18 pp.

Bishop, G.A. 1973. Geology, stratigraphy, and biostratigraphy of the north end of the Cedar Creek Anticline, Dawson County, Montana. Montana Bureau of Mines and Geology Special Publication 61 (single sheet).

Clement, J.H. 1986. Cedar Creek: a significant paleotectonic feature of the Williston Basin. Part II. Northern Rocky Mountains. In J.A. Peterson (editor), Paleotectonics and sedimentation in the Rocky Mountain region, United States: 213-240. Tulsa, OK: American Association of Petroleum Geologists.

Cobban, W.A. 1958. Two new species of Baculites from the Western Interior Region. Journal of Paleontology 32 (4): 660-665.

Cobban, W.A. 1987. The Upper Cretaceous ammonite Rhaeboceras Meek in the Western Interior of the United States. U.S. Geological Survey Professional Paper 1447: 1-15.

Cobban, W.A., and J.B. Reeside, Jr. 1952. Correlation of the Cretaceous formations of the Western Interior of the United States. Bulletin of the Geological Society of America 63: 1011-1044.

Cobban, W.A., E.A. Merewether, T.D. Fouch, and J.D. Obradovich. 1994. Some Cretaceous shorelines in the Western Interior of the United States. In M.V. Caputo, J.A. Peterson, and K.J. Franczyk (editors), Mesozoic systems of the Rocky Mountain region, USA: 393-413. Denver: Rocky Mountain Section of Society for Sedimentary Geology.

Cobban, W.A., I. Walaszczyk, J.D. Obradovich, and K.C. McKinney. 2006. A USGS zonal table for the Upper Cretaceous middle Cenomanian-Maastrichtian of the Western Interior of the United States based on ammonites, inoceramids, and radiometric ages. U.S. Geological Survey Open-File Report 2006-1250: 1-46.

Coryell, H.N., and E.S. Salmon. 1934. A molluscan faunule from the Pierre Formation in eastern Montana. American Museum of Natural History Novitates 746: 1-18.

Cuvier, G. 1797. Tableau élémentaire de l'histoire naturelle des animaux. Paris: Baudouin, xvi, 710 pp.

Davis, R.A., N.H. Landman, J.-L. Dommergues, D. Marchand, and H. Bucher. 1996. Mature modifications and dimorphism in ammonoid cephalopods. In N.H. Landman, K. Tanabe, and R.A. Davis (edi- 
tors), Ammonoid paleobiology: 463-539. New York: Plenum.

DeBaets, K., et al. 2015. Ammonoid intraspecific variability. In C. Klug, D. Korn, K. DeBaets, I. Kruta, and R.H. Mapes (editors), Ammonoid paleobiology: from anatomy to ecology: 369-426. New York: Springer Press..

Dennis, K.J., J.K. Cochran, N.H. Landman, and D.P. Schrag. 2013. The climate of the Late Cretaceous: new insights from the application of the carbonate clumped isotope thermometer to Western Interior Seaway macrofossils. Earth and Planetary Science Letters 362: 51-65.

Dowling, D.B. 1917. The southern plains of Alberta. Geological Survey of Canada Memoir 93: 1-200.

Elias, M.K. 1933. Cephalopods of the Pierre Formation of Wallace County, Kansas, and adjacent area. University of Kansas Science Bulletin 21 (9): 289-363.

Foote, M.J., A.I. Miller, D.M. Raup, S.M. Stanley. 2007. Principles of Paleontology. New York: W.H. Freeman.

Forester, R.W., W.G.E. Caldwell, and F.H. Oro. 1977. Oxygen and carbon isotopic study of ammonites from the Late Cretaceous Bearpaw Formation in southwestern Saskatchewan. Canadian Journal of Earth Sciences 14 (9): 2086-2100.

Foster, M. 1994. Strange genius: the life of Ferdinand Vandeveer Hayden. Niwot, CO: Roberts Rinehart, 443 pp.

Frech, F. 1915. Über Scaphites. I. Die Bedeutung von Scaphites für die Gliederung der Oberkreide. Zentralblatt für Mineralogie Geologie und Paläontologie 1915: 553-568.

Gabb, W.M. 1861. Synopsis of the Mollusca of the Cretaceous Formation, including the geographical and strigraphical range and synonymy. 201 pp.

Gill, J.R., and W.A. Cobban. 1966. The Red Bird section of the Upper Cretaceous Pierre Shale in Wyoming. U.S. Geological Survey Professional Paper 393-A: $1-73$.

Gill, J.R., W.A. Cobban, and L.G. Schultz. 1972. The Sharon Springs Member of the Pierre Shale in western Kansas. U.S. Geological Survey Professional Paper 728: 1-50.

Gill, T. 1871. Arrangement of the families of mollusks. Smithsonian Miscellaneous Collections 227: 1-49.

Grabau, A.W. 1921. A textbook of geology. Part II: historical geology. New York: D.C. Heath, 976 pp.

Grabau, A.W., and H.W. Shimer. 1910. North American index fossils: invertebrates. Vol. 2. New York: A.G. Seiler, 909 pp.
Grier, J.W., J.C. Grier, T. Linn, N.L. Larson, and N.H. Landman. 2019. A new stratigraphy for the Pierre Shale at the Cedar Creek Anticline, Montana. American Association of Petroleum Geologists Datapages, Search and Discovery Article 51627. [doi:10.1306/51627Grier2019]

Grossman, E.L., and T.L. Ku. 1986. Oxygen and carbon isotope fractionation in biogenic aragonite: temperature effects. Chemical Geology 59: 59-74.

Hall, J., and F.B. Meek. 1855. Descriptions of new species of fossils from the Cretaceous formations of Nebraska, with observations upon Baculites ovatus and Baculites compressus, and the progressive development of the septa in baculites, ammonites and scaphites. American Academy of Arts and Science Memoir, new series 5: 379-411.

Hicks, J.F., J.D. Obradovich, and L. Tauxe. 1999. Magnetostratigraphy, isotopic age calibration, and intercontinental correlation of the Red Bird section of the Pierre Shale, Niobrara County, Wyoming, USA. Cretaceous Research 20: 1-27.

Jeletzky, J.A. 1968. Macrofossil zones of the marine Cretaceous of the Western Interior of Canada and their correlation with the zones and stages of Europe and the Western Interior of the United States. Geological Survey of Canada Paper 67-72: 1-66.

Jensen, F.S., and H.D. Varnes. 1964. Geology of the Fort Peck area, Garfield, McCone, and Valley counties, Montana. U.S. Geological Survey Professional Paper 414-F: 1-48.

Jicha, B.R., B.S. Singer, and P. Sobol. 2016. Re-evaluation of the ages of ${ }^{40} \mathrm{Ar} /{ }^{39} \mathrm{Ar}$ sanidine standards and supereruptions in the western U.S. using a Noblesse multi-collector mass spectrometer. Chemical Geology 431: 54-66.

Kauffman, E.G. 1977. Illustrated guide to biostratigraphically important Cretaceous macrofossils, Western Interior Basin, USA. Mountain Geologist 14 (3-4): 225-274.

Kauffman, E.G., and W.G.E. Caldwell. 1993. The Western Interior Basin in space and time. In W.G.E. Caldwell and E.G. Kauffman (editors), Evolution of the Western Interior Basin. Geological Association of Canada Special Paper 39: 1-30.

Kear, A.J., D.E.G. Briggs, and D.T. Donovan. 1995. Decay and fossilization of non-mineralized tissue in coleoid cephalopods. Palaeontology 38 (1): 105131.

Kennedy, W.J. 1986. Campanian and Maastrichtian ammonites from northern Aquitaine, France. Special Papers in Paleontology 36: 1-145. 
Keupp, H. 2006. Sublethal punctures in body chambers of Mesozoic ammonites (forma aegra fenestra n. f.), a tool to interpret synecological relationships, particularly predator-prey interactions. Paläontologische Zeitschrift 80/2: 112-123.

Klein, J. 2016. Lower Cretaceous ammonites X Scaphitoidea, including the Upper Cretaceous representatives. Fossilium catalogus I: Animalia. 157: 1-203. Leiden: Backhuys.

Klompmaker, A.A., N.A. Waljaard, and R.H.B. Fraaije. 2009. Ventral bite marks in Mesozoic ammonites. Palaeogeography, Palaeoclimatology, Palaeoecology 280: 245-257.

Klug, C., M. Zatoń, H. Parent, B. Hostettler, and A. Tajika. 2015. Mature modifications and sexual dimorphism. In Klug, C., D. Korn, K. DeBaets, I. Kruta, and R.H. Mapes (editors), Ammonoid paleobiology: 253-320. New York: Springer Press.

Kröger, B. 2002a. On the ability of withdrawing of some Jurassic ammonoids. In H. Summesberger, K. Histon, and A. Daurer (editors), Cephalopods-present and past. Abhandlungen der Geologischen Bundesanstalt 57: 199-204.

Kröger, B. 2002b. Antipredatory traits of the ammonoid shell-indications from Jurassic ammonoids with sublethal injuries. Paläontologische Zeitschrift 76 (2): 223-234.

Kruta, I., I. Rouget, N.H. Landman, K. Tanabe, and A. Cecca. 2009. Aptychi microstructure in Late Cretaceous Ancyloceratina (Ammonoidea). Lethaia 42 (3): 312-321.

Kruta I., N. Landman, and K. Cochran. 2014. A new approach for the determination of ammonite and nautilid habitats. PLoS ONE 9 (1): e87479. [doi:10.1371/journal.pone.0087479]

Krystinik, L.F., and B.B. DeJarnett. 1995. Lateral variability of sequence stratigraphic framework in the Campanian and lower Maastrichtian of the Western Interior Seaway. In J.C. Van Wagoner and G.T. Bertram (editors), Sequence stratigraphy of foreland basin deposits: outcrop and subsurface examples from the Cretaceous of North America. American Association of Petroleum Geologists Memoir 64: 11-25.

Kuiper, K.F., et al. 2008. Synchronizing rock clocks of Earth history. Science 320: 500-504.

Landes, R.W. 1940. Geology of the southern Alberta plains. Part 2. Palaeontology of the marine formations of the Montana Group. Memoirs of the Canadian Geological Survey 221: 129-217.

Landman, N.H. In press. The Red Bird section of the Upper Cretaceous Pierre Shale and the evolution of scaphitid ammonites (W.A. Cobban memorial volume). Tuksa, OK: American Association of Petroleum Geologists.

Landman, N. H., and S.M. Klofak. 2012. Anatomy of a concretion: Life, death, and burial in the Western Interior Seaway. Palaios 27: 672-693.

Landman, N.H., and K.M. Waage. 1986. Shell abnormalities in scaphitid ammonites. Lethaia 19: 211224.

Landman, N.H., and K.M. Waage. 1993. Scaphitid ammonites of the Upper Cretaceous (Maastrichtian) Fox Hills Formation in South Dakota and Wyoming. Bulletin of the American Museum of Natural History 215: 1-257.

Landman, N.H., J.K. Cochran, D.M. Rye, K. Tanabe, and J.M. Arnold. 1994. Early life history of Nautilus: evidence from isotopic analyses of aquarium-reared specimens. Paleobiology 20 (1): 40-51.

Landman, N.H., et al. 2006. Jaws of Late Cretaceous placenticeratid ammonites: How preservation affects the interpretation of morphology. American Museum Novitates 3500: 1-48.

Landman, N.H., W.J. Kennedy, W.A. Cobban, and N.L. Larson. 2010. Scaphites of the "nodosus group" from the Upper Cretaceous (Campanian) of the Western Interior of North America. Bulletin of the American Museum of Natural History 342: 1-242.

Landman, N. H., W. A. Cobban, and N. L. Larson. 2012. Mode of life and habitat of scaphitid ammonites. In P. Neige and I. Rouget (editors), 8th International Symposium, Cephalopods- Present and Past, Dijon, Aug. 30-Sept. 2, 2010, Geobios 45: 87-98.

Landman, N.H., W.J. Kennedy, W.A. Cobban, N.L. Larson, and S.D. Jorgensen. 2013. A new species of Hoploscaphites (Ammonoidea: Ancyloceratina) from cold methane seeps in the Upper Cretaceous of the U.S. Western Interior. American Museum Novitates 3781: 1-39.

Landman, N.H., W.J. Kennedy, and N.L. Larson. 2015a. A new species of scaphitid ammonite from the lower Maastrichtian of the Western Interior of North America, with close affinities to Hoploscaphites constrictus Sowerby, 1817. American Museum Novitates 3833: 1-40.

Landman, N.H., et al. 2015b. 3-D orientation and distribution of ammonites in a concretion from the Upper Cretaceous Pierre Shale of Montana. Swiss Journal of Paleontology 134 (2): 257-279.

Landman, N.H., J.S. Slatterty, and P.J. Harries. 2016. Encrustation of inarticulate brachiopods on 
scaphitid ammonites and inoceramid bivalves from the Upper Cretaceous U.S. Western Interior. Acta Geologica Polonica 66 (4): 645-662.

Landman, N.H., J.W. Grier, J.K. Cochran, J.C. Grier, J. Petersen, and W.H. Towbin. 2018a. Nautilid nurseries: Hatchlings and juveniles of Eutrephoceras dekayi from the lower Maastrichtian (Upper Cretaceous) Pierre Shale of east-central Montana. Lethaia 51: 48-74.

Landman, N.H., et al. 2018b. ${ }^{40} \mathrm{Ar} /{ }^{39} \mathrm{Ar}$ date of a bentonite associated with a methane seep deposit in the upper Campanian Baculites compressus Zone, Pierre Shale, South Dakota. Cretaceous Research 90: 90-96.

Landman, N.H., et al. 2019. Description of two species of Hoploscaphites (Ammonoidea: Ancyloceratina) from the Upper Cretaceous (lower Maastrichtian) of the U.S. Western Interior. Bulletin of the American Museum of Natural History 427: 1-72.

Larson, N.L. 2003. Predation and pathologies in the Late Cretaceous ammonite family Scaphitidae. MAPS 26 (3): 1-30. Malcolm, IL: Mid America Paleontology Society.

Larson, N.L. 2007. Deformities in the Late Callovian (Late Middle Jurassic) ammonite fauna from Saratov, Russia. In N.H. Landman, R.A. Davis, and R.H. Mapes (editors), Cephalopods present and past: new insights and fresh perspectives: $344-374$. Dordrecht: Springer.

Larson, N.L., S.D. Jorgensen, R.A. Farrar, and P.L. Larson. 1997. Ammonites and the other cephalopods of the Pierre Seaway. Tucson, AZ: Geoscience Press, $148 \mathrm{pp}$.

Lehmann, U. 1981. The ammonites: their life and their world. New York: Cambridge University Press.

Linn, T. 2010. Biostratigraphic zonation of fossil cephalopods in the upper unnamed shale member of the Pierre Shale in the Cedar Creek Anticline of Dawson County, MT. Senior B.S. research paper, Department of Geology, South Dakota School of Mines and Technology, Rapid City, South Dakota, 28 pp.

Linnert, C., et al. 2018. Did Late Cretaceous cooling trigger the Campanian-Maastrichtian Boundary Event? Newsletters on Stratigraphy 51 (2): 145-166.

Logan, W.N. 1899. Contributions to the paleontology of the Upper Cretaceous series. Field Columbian Museum Publication 36. Geological Series 1 (6): 205-216.

Lynds, R.M., and J.S. Slattery. 2017. Correlation of the Upper Cretaceous stratigraphy of Wyoming. Open File Report 2017-3. Wyoming State Geological Survey. Laramie, Wyoming.
Machalski, M.J., J.W.M. Jagt, N.H. Landman, and N. Motchurova-Dekova. 2007. The highest records of North American scaphitid ammonites in the European Maastrichtian (Upper Cretaceous) and their stratigraphic implications. Acta Geologica Polonica 2: 169-185.

Meek, F.B. 1864. Check list of the invertebrate fossils of North America. Cretaceous and Jurassic. Smithsonian Miscellaeous Collections 177: 1-40.

Meek, F.B. 1876. A report on the invertebrate Cretaceous and Tertiary fossils of the upper Missouri country. United States Geological Survey of the Territories Report 9: 1-629, pls. 1-45.

Meek, F.B., and F.V. Hayden 1856. Descriptions of new species of Gasteropoda and Cephalopoda from the Cretaceous formations of Nebraska Territory. Proceedings of the Academy of Natural Sciences, Philadelphia 8: 63-126.

Meek, F.B., and F.V. Hayden. 1860a. Description of new organic remains from the Tertiary, Cretaceous and Jurassic rocks of Nebraska. Proceedings of the Academy of Natural Sciences of Philadelphia (for 1860): 175-185. [erroneously listed as 1861 in Klein, 2016]

Meek, F.B., and F.V. Hayden. 1860b. Systematic catalogue, with synonyma, etc., of Jurassic, Cretaceous and Tertiary fossils collected in Nebraska, by the exploring expeditions under the command of Lieut. G.K. Warren, of U.S. Topograghical Engineers. Proceedings of the Academy of Natural Sciences of Philadelphia 12: 417-432.

Meek, F.B., and F.V. Hayden. 1861. Descriptions of new Lower Silurian (Primordial), Jurassic, Cretaceous and Tertiary fossils collected in Nebraska by the exploring expedition under the command of Captain W.F. Raynolds, U.S. Topographical Engineer, with some remarks on the rocks from which they were obtained. Proceedings of the Academy of Natural Sciences of Philadelphia: 415-447.

Min, K., R. Mundil, P.R. Renne, and K.R. Ludwig. 2000. A test for systematic errors in ${ }^{40} \mathrm{Ar} /{ }^{39} \mathrm{Ar}$ geochronology through comparison with $\mathrm{U} / \mathrm{Pb}$ analysis of a 1.1-Ga rhyolite. Geochimica Cosmochimica Acta 64: 73-98.

Naglik, C., A. Tajika, J. Chamberlain, and C. Klug. 2015. Ammonoid locomotion. In C. Klug, D. Korn, K. DeBaets, I. Kruta, and R.H. Mapes (editors). Ammonoid paleobiology: from anatomy to ecology: 649-688. New York: Springer.

Nowak, J. 1911. Untersuchungen über die Cephalopoden der oberen Kreide in Polen. II Teil: die 
Skaphiten. Bulletin de l'Académie des Sciences de Cracovie Série B 7: 547-589.

Nowak, J. 1916. Zur Bedeutung von Scaphites für die Gliederung der Oberkreide. Verhandlungen der Kaiserlichen und Königlichen Geologischen Reichsanstalt für 1915. 3: 55-67.

Owen, D.D. 1852. Report of a geological survey of Wisconsin, Iowa, and Minnesota; and incidentally of a portion of Nebraska Territory made under instructions from the United States Treasury Department. Philadelphia: Lippincott, Grambo, \& Co., 2 vols., 638 pp.

Palamarczuk, S., and N.H. Landman. 2011. Dinoflagellate cysts from the upper Campanian Pierre Shale and Bearpaw Shale of the U.S. Western Interior. Rocky Mountain Geology 46 (2): 137-164.

Peterman, D.J., et al. 2020. Syn vivo hydrostatic and hydrodynamic properties of scaphitid ammonoids from the U.S. Western Interior. Geobios 60: 79-98.

Peterson, J.A., and L.M. MacCary. 1987. Regional stratigraphy and general petroleum geology of the U.S. portion of the Williston Basin and adjacent areas. Williston Basin: Anatomy of a Cratonic Oil Province. In J.C. Van Wagoner, and G.T. Bertram (editors), Sequence stratigraphy of foreland basin deposits: 9-43. Denver: American Association of Petroleum Geologists Memoir 64, Rocky Mountain Association of Geologists.

Quaas, A. 1902. II. Die Fauna der Overwegischichten und der Blätterthone in der libyschen Wüste. Palaeontographica 30 (2): 153-336.

Radwański, A.1996. The predation upon, and the extinction of, the latest Maastrichtian populations of the ammonite species Hoploscaphites constrictus (J. Sowerby, 1817) from the Middle Vistula Valley, Poland. Acta Geologica Polonica 46 (1-2): 117-135.

Reeside, J.B., Jr. 1927. The scaphites, an Upper Cretaceous ammonite group. U.S. Geological Survey Professional Paper 150-B: 21-40.

Reiskind, J. 1975. Marine concretionary faunas of the uppermost Bearpaw Shale (Maestrichtian) in eastern Montana and southwestern Saskatchewan. Geological Association of Canada Special Paper 13: 235-252.

Riccardi, A.C. 1983. Scaphitids from the Upper Campanian-lower Maastrichtian Bearpaw Formation of the Western Interior of Canada. Geological Survey of Canada Bulletin 354: 1-51.

Ryan, D., J.D. Witts, and N.H. Landman. In press. Paleoecological analysis of a methane seep deposit from the Upper Cretaceous of the U.S. Western Interior. Lethaia.
Salzburger W., A. Meyer, S. Baric, E. Verheyen, and C. Sturmbauer. 2002. Phylogeny of the Lake Tanganyika cichlid species flock and its relationship to the Central and East African haplochromine cichlid fish faunas. Systematic Biology 51(1): 113-135.

Schuchert, C. 1905. Catalogue of the type specimens of fossil invertebrates in the Department of Geology, United States National Museum. Bulletin of the United States National Museum 53 (1): 1-704.

Shackleton, N.J., and J.P. Kennett. 1975. Paleotemperature history of the Cenozoic and initiation of Antarctic glaciation: oxygen and carbon isotope analyses in DSDP sites 277, 279, and 281. Initial Reports of the Deep Sea Drilling Program 29: 743755.

Shimer, H.W., and R.R. Shrock. 1944. Index fossils of North America. Cambridge, MA: M.I.T. Press, 837 pp.

Shurr, G.W., G.A. Ludvingson, and R.H. Hammond. 1994. Introductory remarks: perspectives on the eastern margin of the Cretaceous Western Interior Seaway. In G.W. Shurr, G.A. Ludvingson, and R.H. Hammond (editors), Perspectives on the eastern margin of the Cretaceous Western Interior Seaway. Geological Society of America Special Paper 287: 1-4.

Slattery, J.S., P.J. Harries, and A.L. Sandness. 2018. Do marine faunas track lithofacies? Faunal dynamics in the Upper Cretaceous Pierre Shale, Western Interior, USA. Palaeogeography, Palaeoclimatology, Palaeoecology 496: 205-224.

Smith, W.D. 1905. The development of Scaphites. Journal of Geology 13 (7): 635-654.

Sowerby, J. 1817. The mineral conchology of Great Britain, vol. 2. London: the author. [7 vols.]

Stanton, T.W., and J.B. Hatcher. 1905. Geology and paleontology of the Judith River beds. U.S. Geological Survey Bulletin 257: 1-123.

Takeda, Y., K. Tanabe, T. Sasaki, and N.H. Landman.2016. Durophagous predation on scaphitid ammonoids in the Late Cretaceous Western Interior Seaway of North America. Lethaia 49: 28-42.

Thomel, G. 1980. Ammonites. Nice, France: Serre, 227 pp.

Walaszczyk, I., W.A. Cobban, and P.J. Harries. 2001. Inoceramids and inoceramid biostratigraphy of the Campanian and Maastrichtian of the United States Western Interior Basin. Revue Paléobiologie, Genève 20 (1): 117-234.

Warren, P.S. 1931. Invertebrate paleontology of southern plains of Alberta. American Association of Petroleum Geologists Bulletin 15 (10): 1283-1291. 
Whiteaves, J.F. 1885. Report on the Invertebrata of the Laramie and Cretaceous rocks of the vicinity of the Bow and Belly River and adjacent localities in the Northwest Territory. Contributions to Canadian Palaeontology 1: 1-89.

Whitfield, R.P. 1877. Preliminary report on the paleontology of the Black Hills, containing descriptions of new species of fossils from the Potsdam, Jurassic, and Cretaceous formations of the Black Hills of Dakota. U.S. Geographical and Geological Survey Rocky Mountain Region Report (Powell), 49 pp.

Wiedmann, J. 1966. Stammesgeschichte und System der postriadischen Ammonoideen: ein Überblick. Neues Jahrbuch für Geologie und Paläontologie Abhandlungen 125: 49-79; 127: 13-81.

Williams, G.D., and C.R. Stelck. 1975. Speculations on the Cretaceous palaeogeography of North America. In W.G.E. Caldwell (editor), The Cretaceous system in the Western Interior of North America. Geological Association of Canada Special Paper 13: 1-20.

Wright, C.W. 1996. Treatise on invertebrate paleontology: Mollusca 4, Cephalopoda: Ammonoidea. Boulder, CO: Geological Society of America.

Yacobucci, M.M. 1999. Plasticity of developmental timing as the underlying cause of high speciation rates in ammonoids. In F. Oloriz and F.J. Rodriguez-Tovar (editors), Advancing research in living and fossil cephalopods: 59-76. New York: Springer.

Zittel, K.A.von.1884. Handbuch der Paläontologie. Abteilung 1. Band 2: 329-522. Munich: R. Oldenbourg. 


\section{APPENDIX}

\section{LIST OF LOCALITIES}

Localities are from the American Museum of Natural History (AMNH), the U.S. Geological Survey (USGS), and the Yale Peabody Museum (YPM). The names of collectors and dates of collection are indicated at the end of each entry, where known. In the USGS numbers, the prefix D refers to Denver locality numbers and the others refer to Washington, D.C., locality numbers.

\section{AMNH LOCALITIES}

3194. Kara Bentonitic Member and upper unnamed shale member, Pierre Shale, $\mathrm{N}^{1} \frac{4}{4}$ sec. 17, T. 46 N., R. 64 W., Osage Oilfield, near Osage, Weston County, Wyoming.

3244. Baculites eliasi-B. grandis zones, Pierre Shale, SE $1 / 4$ sec. $35+$ SW $^{1 / 4}$ sec. 36 , T. 14 N., R. 55 E. + NE1/4 sec. $2+\mathrm{NW}^{1 / 4} \mathrm{sec} .1$, T. 13 N., R. 55 E., south of Glendive, Dawson County, Montana. [Biostratigraphic information may be more precise for a particular specimen, as recorded in the field notes and on the label].

3245. Baculites eliasi-B. grandis zones, Pierre Shale, SW $1 / 4$ sec. 35, T. 14 N., R. 55 E., south of Glendive, Dawson County, Montana. [Biostratigraphic information may be more precise for a particular specimen, as recorded in the field notes and on the label].

3246. Baculites baculus-B. grandis zones, Pierre Shale, $\mathrm{W}^{1 / 2} \mathrm{sec} .5+\mathrm{NE}^{1 / 4} \mathrm{sec}$. 6 , T. $12 \mathrm{~N}$., R. 57 E. + south-central 1/2 sec. 35 , T. 13 N., R. 57 E., southwest of Wibaux (= Mingusville), Wibaux County, Montana. [Biostratigraphic information may be more precise for a particular specimen, as recorded in the field notes and on the label].

3270. Baculites baculus Zone, Pierre Shale, SW 1/4 sec. 6, T. 13 N., R. 56 E., south of Glendive, Dawson County, Montana. [Biostratigraphic information may be more precise for a particular specimen, as recorded in the field notes and on the label].

3730 (= G71488). Baculites baculus-B. grandis zones, mostly in and below $8 \mathrm{ft}(2.4 \mathrm{~m})$ thick bentonite noted by Gill and Cobban (1966), upper unnamed shale member, Pierre Shale, in an area trending northeast across Brewster Draw, 2.1-2.5 mi (3.4-4.0 km) northnortheast of Red Bird, from SW $1 / 4$ to NW1/4 $\mathrm{NE}^{1 / 4} \mathrm{NE}^{1 / 4}$ sec. 14, T. 38N., R. 62W., Niobrara County, Wyoming. 1988. [Biostratigraphic information may be more precise for a particular specimen, as recorded in the field notes and on the label].

3921. Baculites baculus-B. grandis zones, Pierre Shale, Cedar Creek Anticline, Wibaux, Dawson, Fallon, and Prairie counties, Montana. [Biostratigraphic information may be more precise for a particular specimen, as recorded in the field notes and on the label].

\section{USGS LOCALITIES}

7215. Pierre Shale, sec. 28, T. 46 N., R. 64 W., Weston County, Wyoming. 1911.

9797. Bearpaw Shale, NW11/4 sec. 5, T. 2 N., R. 19 E., Stillwater County, Montana. W.T. Thom, Jr., for E.T. Hancock. 1916.

10771. Bearpaw Shale, concretions in bed of Prairie Elk Creek $0.25 \mathrm{mi}(0.4 \mathrm{~km})$ southeast of ranch house, sec. 35, T. 26 N., R. 45 E., McCone County, Montana. W.T. Thom and T.W. Stanton. 1921.

11217. Upper part of Pierre Shale, about $100 \mathrm{ft}$ $(30.5 \mathrm{~m})$ below base of Fox Hills Formation, about $6.5 \mathrm{mi}(10.4 \mathrm{~km})$ east of Upton, Weston County, Wyoming. C.R. Longwell and W.W. Rubey. 1922.

12745. Baculites baculus Zone, Pierre Shale, south of Glendive, Dawson County, Montana. E.E. Teller. 1924.

22141. Bearpaw Shale, 100 - $150 \mathrm{ft}(30.5-45.7 \mathrm{~m})$ below the Fox Hills Sandstone. SE $1 / 4$ sec. 
11, T. 26 N., R. 41 E., Valley County, Montana. F.S. Jensen. 1949.

22142. Baculites elaisi Zone, upper part of Bearpaw Shale, E⿺辶/2 sec. 5 and $\mathrm{W}^{1 / 2}$ sec. 4, T. 26 N., R. 42 E., Valley County, Montana. W.A. Cobban and F.S. Jensen. 1948.

23396. Bearpaw Shale, NE1/4 SW11/4 sec. 23, T. 27 N., R. 45 E., Valley County, Montana. R.B. Colton. 1950. [Collection mixed in office, but all specimens believed to be from same horizon].

23399. Bearpaw Shale, SW $1 / 4$ NE $1 / 4$ sec. 23, T. 27 N., R. 45 E., Valley County, Montana. R.B. Colton. 1950.

D430. Baculites baculus Zone, red concretion zone at top of middle member, Pierre Shale, $7 \mathrm{mi}(11.2 \mathrm{~km})$ southeast of Moorcroft, sec. 2, T. 48 N., R. 67 W., Weston County, Wyoming. W.J. Mapel, C.S. Robinson, and W.A. Cobban. 1955.

D1047. Baculites baculus Zone, Pierre Shale, from gray calcareous concretions $77-87 \mathrm{ft}$ (23.5 - $26.4 \mathrm{~m}$ ) below top, $10 \mathrm{mi}(16 \mathrm{~km})$ south of Glendive, near center of $\mathrm{E}^{1 / 2} \mathrm{E}^{1 / 2}$ sec. 27, T. 14 N., R. 55 E., Dawson County, Montana (same locality as D1045). W.A. Cobban. 1956.

D1636. Baculites eliasi Zone, Pierre Shale, from ferro-calcareous concretions 190-200 ft (57.9-60.1 m) below top of Kara Bentonitic Member, E1/2 NE1/4 NW1/4 sec. 23, T. 38 N., R. 62 W., Niobrara County, Wyoming (same locality as D1956). H.A. Tourtelot, J.R. Gill, C.S. Robinson, W.J. Mapel, and W.A. Cobban. 1957, 1958.

D1967. Baculites eliasi Zone, Pierre Shale, from limestone concretions $37 \mathrm{ft}(11.3 \mathrm{~m})$ above top of Kara Bentonitic Member, NE $1 / 4$ NW $1 / 4$ SE $1 / 4$ sec. 14, T. 38 N., R. 62 W., Niobrara County, Wyoming (same locality as D1959). J.R. Gill, W.J. Mapel, C.S. Robinson, and H.A. Tourtelot. 1958.

D1973. Baculites baculus Zone, Pierre Shale, from brownish limestone concretions $117 \mathrm{ft}$ (35.7 $\mathrm{m})$ above top of Kara Bentonitic Member, SW1/4 NE $1 / 4 \mathrm{NE}^{1 / 4} \mathrm{NW}^{1} 1 / 4$ sec. 23 , T. 38 N., R.
62 W., Niobrara County, Wyoming (same locality as D1971). W.A. Cobban. 1958.

D1974. Baculites baculus Zone, Pierre Shale, from highly fossiliferous limestone concretions $147 \mathrm{ft}$ ( $44.8 \mathrm{~m})$ above top of Kara Bentonitic Member, SW $1 / 4$ NE1/4 NW1/4 sec. 23, T.38 N., R. 62 W., Niobrara County, Wyoming. W.A. Cobban. 1958.

D1975. Baculites baculus Zone, Pierre Shale, same level as D1974, near center of north line of $\mathrm{NE}^{1 / 4} \mathrm{NW}^{1 / 4} \mathrm{SE}^{1} / 4 \mathrm{sec} .14$, T. $38 \mathrm{~N}$., R. 62 W., Niobrara County, Wyoming. H.A. Tourlelot, W.J. Mapel, J.R. Gill, C.S. Robinson, and W.A. Cobban. 1958.

D1976. Baculites baculus Zone, Pierre Shale, from a gray limestone concretion $157 \mathrm{ft}(47.8 \mathrm{~m})$ above top of Kara Bentonitic Member, $\mathrm{SW}^{1 / 1} / 4 \mathrm{NE}^{1 / 4} \mathrm{NE}^{1 / 4} \mathrm{NW}^{1 / 1} / 4$ sec. 23, T. 38 N., R. 62 W., Niobrara County, Wyoming (same locality as D1971). W.A. Cobban. 1958.

D1981. Baculites baculus Zone, Pierre Shale, about $205 \mathrm{ft}(62.5 \mathrm{~m})$ above top of Kara Bentonitic Member, S1/2 SE1/4 SE $1 / 4$ SW $1 / 2$ sec. 14, T. 38 N., R. 62 W., Niobrara County, Wyoming (same locality as D1978). J.R. Gill, W.J. Mapel, C.S. Robinson, and H.A. Tourtelot. 1958.

D3338. Lewis Shale, about $100 \mathrm{ft}(30.5 \mathrm{~m})$ above base, SE1/4SW11/4 sec. 6, T. 21 N., R. 88 W., Carbon County, Wyoming. H.A. Tourtelot. 1961.

D4760 (G64-1-4) = D4761 (G64-1-19). Baculites eliasi Zone, Lewis Shale, NE1/4 SW1/4 sec. 19, T. 23 N., R. 79 W., Carbon County, Wyoming. R.C. Givens. 1964.

\section{YPM LOCALITIES}

A4778. Lower part of Baculites baculus Zone, unit 89 of Traverse A (Gill and Cobban, 1966), upper unnamed shale member, Pierre Shale, gulley west of fence, 1.8 mi $(2.9 \mathrm{~km})$ northeast of Red Bird, NW1/4 sec. 23, T. 62 W., R. 38 N., Niobrara County, Wyoming. K.M. Waage and C.W. Byers II, 1971. 
A6520. Pierre Shale, Sage Creek, Pennington County, South Dakota. G.A. Clarke, 1860. (Questionable locality because of the date of the collection)

A6521. Fort Yates, Sioux County, North Dakota. 1893. (Questionable locality because of the date of the collection)

C1503. Baculites baculus Zone, Pierre Shale, Wibaux (= Mingusville), Wibaux County, Montana.

C3353. Pierre Shale, west of Moorcroft, Crook County, Wyoming. K.M. Waage and E. Dorf, 1937. 